Ernani Vassoler Rodrigues

\title{
As redes da sala de aula: complexidade e estruturações emergentes
}

São Paulo, SP 


\title{
Ernani Vassoler Rodrigues
}

\section{As redes da sala de aula: complexidade e estruturações emergentes}

\author{
Tese submetida à Faculdade de Educação da \\ Universidade de São Paulo, para fim de ob- \\ tenção de título de Doutor em Educação \\ Universidade de São Paulo - USP \\ Faculdade de Educação \\ Programa de Pós-Graduação em Educação
}

Orientador: Prof. Dr. Maurício Pietrocola Pinto de Oliveira

São Paulo, SP

2020 
Autorizo a reprodução e divulgação total ou parcial deste trabalho, por qualquer meio convencional ou eletrônico, para fins de estudo e pesquisa, desde que citada a fonte.

Catalogação da Publicação

Ficha elaborada pelo Sistema de Geração Automática a partir de dados fornecidos pelo(a) autor(a) Bibliotecária da FE/USP: Nicolly Soares Leite - CRB-8/8204

Rodrigues, Ernani

As redes da sala de aula: complexidade e estruturações emergentes / Ernani Rodrigues; orientador Maurício Pietrocola. -- São Paulo, 2020. $226 \mathrm{p}$.

Tese (Doutorado - Programa de Pós-Graduação Educação Científica, Matemática e Tecnológica) -Faculdade de Educação, Universidade de São Paulo, 2020 .

1. Ciência das redes. 2. Ensino de ciências. 3. Redes semânticas. 4. Redes sociais. 5. Representações sociais. I. Pietrocola, Maurício, orient. II. Título. 


\title{
As redes da sala de aula: complexidade e estruturações emergentes
}

Tese submetida à Faculdade de Educação da Universidade de São Paulo, para fim de obtenção de título de Doutor em Educação

Tese aprovada. São Paulo, SP, de de 2020:

\author{
Prof. Dr. Maurício Pietrocola Pinto \\ de Oliveira \\ Orientador - FEUSP
}

\author{
Profa. Dra. Alcina Maria Testa Braz \\ da Silva \\ Avaliadora - CEFET-RJ
}
Prof. Dr. André Machado Rodrigues Avaliador - IFUSP

Prof. Dr. Geide Rosa Coelho

Avaliador - UFES

Profa. Dra. Giselle Watanabe

Avaliadora - UFABC

São Paulo, SP

2020 
Este trabalho é dedicado a todos os professores que, diariamente, caminham escola a dentro para participarem ativamente do desenvolvimento da humanidade. 


\section{Agradecimentos}

Estar na posição de candidato a título de doutor é viver um privilégio. Esse privilégio é sustentado por inúmeros viabilizadores, desde fiadores institucionais até incentivadores no âmbito pessoal. Um doutoramento não é, sob nenhuma hipótese, conquista unicamente atribuída ao candidato. Reconhecer isso com a devida humildade é, primeiro, afastar a falácia da meritocracia, excludente de tantos cidadãos a quem oportunidades como as que eu tive são, diariamente, negadas. E é também reconhecer a responsabilidade inerente ao privilégio a mim concedido, bem como a fundamental importância de cada indivíduo que, nominal ou anonimamente, tornou possível o desenvolvimento e a conclusão dessa etapa de formação. Por isso, não sem risco de ser injusto, dirijo meus agradecimentos.

Na esfera institucional, agradeço nominalmente à CAPES, pelo financiamento desta pesquisa, dado por meio de Bolsa de Doutorado e por meio de Bolsa de Doutorado Sanduíche no Exterior (PDSE). Ainda nessa esfera, agradeço aos tantos contribuintes que, de maneira anônima e por meio de impostos recolhidos, permitiram tal financiamento.

Na minha trajetória acadêmica, agradeço a todos que, amigavelmente, me conduziram em cada etapa. Nominalmente, agradeço a L. Ferracioli, G. Camiletti e G. Coelho, da UFES, que guiaram meus primeiros passos acadêmicos. Agradeço a cada docente com quem pude cursar disciplinas durante o doutoramento. Nominalmente a M. Giordan, L. Sasseron, P. Correia e U. Araújo, da USP. Também a R. Duschl (Penn State University), M. Jiménez-Aleixandre (University of Santiago de Compostela), B. Freeman e E. Turiel (UC-Berkeley). Agradeço, em especial, a A. diSessa, que carinhosamente me recebeu por dois ciclos completos, sendo o último deles em meu PDSE, na UC-Berkeley. Também de lá, a G. Saxe, com quem pude discutir aspectos fundamentais desta tese.

Reservo um agradecimento particularmente caro a meu orientador, M. Pietrocola que, em todos os momentos, me incentivou e me levou a olhar horizontes mais distantes, ampliando com isso não só minha visão acadêmica, mas minha visão de mundo.

Agradeço a meus amigos de laboratório, C. Mometti, K. Saucedo, S. Schnorr, A. Sabino, H. João, J. Ogata, R. Valois, A. E. Borges e I. Vasconcelos, P. diNuovo, P. Ruggieri e L. Saluchi, por tantos cafés e sessões de compartilhamento de angústias, de vitórias e de bases teóricas. Aos amigos de sala de aula e de pesquisa, W. Carminatti e P. Prezotti, sempre puxando pra cima. Aos amigos D. Amorim e A. Delgado, pelos debates mais intensos. A F. Leite (in memorian) e todos os companheiros de escola, com quem até hoje divido alegrias. Também a A. Barcellos, A. B. Borges e F. Portela pela amizade de longa data e por confiarem em mim, mais que eu mesmo. Uma sorte tê-los.

Na minha trajetória de vida, tive também o privilégio de uma família apoiadora e 
dedicada. Por isso agradeço a meus pais, Ilso e Jodithe que, contra qualquer adversidade, sempre viram na escolarização dos filhos um caminho de emancipação que lhes fora inicialmente negado. $\mathrm{O}$ amor e o apoio incondicionais deles foram meu motor primeiro.

Também a minhas irmãs, Elisângela e Elaine, que tiveram a audácia me alfabetizar muito cedo, ainda em casa, o que me impulsionou na vida escolar. Manas de zelo tão amoroso, me deixando sempre seguro frente aos primeiros desafios. A Omar, meu cunhado, que vibrou comigo as minhas primeiras vitórias acadêmicas, quando ingressei na Escola Técnica, ainda adolescente. A Maria Vitória, por sua alegria leve e a Henrique, por seu companheirismo amável.

Agradeço a meus sogros, João e Domingas, pelo gigantesco apoio logístico nesses anos, transformando minha estada em São Paulo em um tempo maravilhoso. Ainda no seio familiar, com dois pés na ciência, não haveria agradecimento suficiente para a pessoa que me mostrou a academia. Que revisou meus primeiros rascunhos ainda na minha graduação. Que me mostrou, pelo exemplo de suas atitudes, como é ser um pesquisador compromissado, como é ser um orientador construtivo, como é ser um revisor de artigos que colabora para o texto, respeitando absolutamente a autoria e o produto que um outrem venha a submeter a seu crivo. Que sempre trouxe palavras de apoio. Um agradecimento a Carol Loss, minha esposa, que me ensina a cada dia e que me dá a sorte de caminhar a seu lado.

A todos que não mencionei aqui, mas que contribuíram de maneiras que só consigo imaginar e de outras que nem isso, meu muito obrigado. 
Sentir fundo e pensar forte para bater no teto de tudo e prosseguir claraboia acima

(Carlos Ayres Britto) 


\section{Resumo}

RODRIGUES, E. V. As redes da sala de aula: complexidade e estruturações emergentes. 2020. Tese (Doutorado) - Faculdade de Educação, Universidade de São Paulo, São Paulo, 2020.

O aspecto relacional que caracteriza as situações reais promove um arranjo complexo emergente. Essa complexidade é inerente a uma sala de aula típica. Diferentes formas de relações fazem emergir estruturações complexas em diferentes níveis de observação e de detecção. Tomando-se um sistema didático como indicador das diferentes dimensões da complexidade, é possível avaliar dois domínios, o interpessoal e o representacional dos alunos, como sistemas complexos adjacentes que se sobrepõem. A influência mútua entre estruturas sociais e processos de compartilhamento de ideias é tema de interesse da pesquisa em educação, uma vez que permite a elucidação das relações entre afiliações aluno-aluno e a formação de consenso sobre temas de ensino. Diante de estruturações relacionais complexas, a escolha de aportes teóricos e de propostas metodológicas, dentro do viés da complexidade, é um desafio. No sentido de superar tal desafio, tomamos uma abordagem que se solidifica em diversas áreas das ciências, nas quais as estruturações complexas são características: a Ciência das Redes. Mais do que apenas método, nesta tese utilizamos as redes também como forma de se pensar a complexidade da sala de aula. Visitando seus fundamentos e sua relação com teorias sistêmicas, elaborarmos usos das redes para a pesquisa educacional. Lançamos mão da Teoria dos Grafos para representar explicitamente arranjos complexos, emergentes da sala de aula. Traçamos um panorama dos usos das redes na pesquisa em educação em ciências e definimos duas frentes de investigação, localizando redes complexas no sistema didático. Numa delas, redes semânticas funcionam como referentes da complexidade das estruturas de Representações Sociais produzidas pelos alunos. Na outra, redes sociais, obtidas por testes sociométricos, são referentes da complexidade do arranjo interpessoal dos alunos. Procedemos um estudo de caso em uma sala de aula de Física do Ensino Médio, agregando redes, tanto sociais quanto semânticas. Então, por uma redução dimensional pudemos analisar a influência da força dos laços interpessoais na formação de consensos acerca de diferentes objetos representacionais. Nossos resultados indicaram uma dimensão prioritária, na qual consensos mais dependentes do peso dos laços sociais se remetem mais a temas intra-escolares. Já os consensos formados sobre temas extra-escolares se mostraram menos dependentes dos laços sociais entre os alunos. Isso apontou a necessidade de se incluir o aspecto estritamente social dos alunos como variável relevante ao processo de compartilhamento de ideias sobre temas da escola.

Palavras-chaves: ciência das redes. ensino de ciências. redes semânticas. redes sociais. representações sociais. 


\section{Abstract}

RODRIGUES, E. V. Classroom networks: complexity and emerging structures. 2020. Tese (Doutorado) - Faculdade de Educação, Universidade de São Paulo, São Paulo, 2020.

The relational aspect that characterizes real situations promotes emerging complex sets. In a typical classroom, this inherent complexity is a characteristic factor. From different forms of relationships, complex structures emerge at different levels of observation and detection. Therefore, taking a didactic system as an indicator of different dimensions of classrooms complexity, it is possible to evaluate two domains: the interpersonal and the students representational one. They work as adjacent and overlaping complexities. The mutual influence between social structures and processes of sharing ideas is subject of interest in educational research since it allows one to elucidate relationships between student-student affiliations and emergence of consensus on teaching mathers. However, it is challenging to explore complex relational structures, because it demands both theoretical frameworks and the methodological tools operating within a complexity perspective. In order to overcome this challenge, we borrowed from an approach that is solidified in several fields of science research, in which complex structures are characteristic: the Network Science. More than just a method, in this thesis we use networks also as a way for thinking the complexity of the classroom. We visited some of Network Science foundations, building on different systemic theories arguments for using networks as classroom's research approach. In addition, we took graph theory as a formal way to explicitly represent emerging complex arrangements, such as classroom sets. Through a systematic review, we provide an overview on the use of networks in science education research. It allowed us to define two research strands, locating complex networks in the didactic system. In one hand, semantic network functions as referents for complex structures of social representations, produced by students, in the classroom. In the other hand, social network, gathered from sociometric tests, refers to complexity of interpersonal arrangement. On these two fronts, we proceeded a case study in a high school Physics classroom, aggregating networks, both from social and semantic realms. Then, via a dimensional reduction of variables taken from these two domains, we were able to analyze the influence of interpersonal ties strength and the consensus formation on different representational objects. Our findings indicated a main component in which consensus more dependent on the social ties weights were the ones most related to intra-school themes, while consensus formed on out-of-school themes were less dependent on student-student social ties. This pointed to the need of including students' strictly social aspect as a relevant variable of the sharing ideas on school themes process.

Keywords: science education. semantic networks. network science. social networks. social representation. 


\section{Lista de ilustrações}

Figura 1 - Representação esquemática do sistema didático. Os estudantes (les élèves, E), a/o professora(o) (l'enseignant, P) e o saber ensinado (le savoir enseigné, $\mathrm{S}) \ldots \ldots$. . . . . . . . . . . . . . . 4 43

Figura 2 - Representação esquemática da relação entre os conhecimentos do mundo e os sistemas de ensino e didáticos . . . . . . . . . . . . . . . 46

Figura 3 - Aresta do Sistema Didático e seus polos tomados como objeto de interesse 49

Figura 4 - Representação esquemática de diferentes tipos de sistemas hipotéticos . 70

Figura 5 - Quadro de trabalho Cynefin e tipificação de situações e problemas . . . 82

Figura 6 - Representação esquemática do processo de evolução conceitual, em um sistema complexo composto por fragmentos de conhecimento . . . . . . 95

Figura 7 - Dois momentos produtores de informação nos quais se dão o estabelecimento de relações entre o mundo e as inscrições . . . . . . . . . . . . . 101

Figura 8 - Representação esquemática das sete pontes de Köningsberg. À esquerda, o original de Euler. Ao centro, uma geometria das posições. À direita, o grafo representacional do problema . . . . . . . . . . . . . . . . . . 110

Figura 9 - Representação hipotética do mapa de uma região, com a indicação das localidades-sede e suas fronteiras . . . . . . . . . . . . . . . 112

Figura 10 - Processo de representação das cidades vizinhas por uma rede de adjacências: mais à esquerda o mapa da região e mais à direita o grafo das relações de vizinhança . . . . . . . . . . . . . . . . . . . 112

Figura 11 - Exemplo de um grafo com quatro vértices e duas arestas (esq.). Ao centro, a escrita algébrica do grafo, como conjunto de pares. À direita a representação matricial do grafo, com a matriz binária de adjacências . 114

Figura 12 - Rede das cidades vizinhas, representadas pelo grafo, à esquerda e pela matriz de adjacências, à direita . . . . . . . . . . . . . . . . . . . . . . 114

Figura 13 - Utilização da matriz de adjacência para o cômputo do grau de cada vértice (à esquerda); representação imagética do grafo, com cada vértice tendo tamanho proporcional a seu grau (ao centro) e distribuição dos graus, por conjunto de vértices (à direita) . . . . . . . . . . . . 116

Figura 14 - Comparativo entre matrizes de adjacências para os grafos não direcionados e para os grafos direcionados . . . . . . . . . . . . . 116

Figura 15 - Cômputo do grau de um vértice, para grafos não direcionados (à esquerda) e cômputo dos graus de entrada e de saída para grafos direcio-

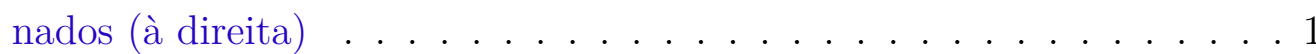


Figura 16 - Grafo não direcionado, com arestas pesadas em sua representação imagética (sup.), matricial (inf. à esquerda) e o heatmap referente (inf. à direita) . . . . . . . . . . . . . . . . . . 118

Figura 17 - Levantamento de publicações dos últimos 20 anos, feita na base ERIC, acerca de Network Science. Acesso em 22/04/2018 . . . . . . . . . . . . 125

Figura 18 - Distribuição dos trabalhos levantados na revisão sistemática, representados por abordagem e por modelagem (A); pelas formas de utilização das redes (B) e a concentração de trabalhos por períódico (C) . . . . . .

Figura 19 - Rede cientométrica. Círculos representam autores, com diâmetro proporcional ao número de aparições; triângulos representam o tipo de rede utilizada explicitamente nos trabalhos; hexágonos representam as revistas científicas que apareceram mais de uma vez. Abaixo, destaque para os papéis das revistas (inferior esquerda) e dos temas (inferior, centro) como pontes entre grupos e destaque para as comunidades de aglomeração das publicações. . . . . . . . . . . . . . . . . . 128

Figura 20 - Mapa do Brasil (A), destaque para o estado do Espírito Santo e a cidade austral Bom Jesus do Norte (B) e destaque para a cidade fluminense de Bom Jesus de Itabapoana, ao sul do Rio Itabapoana e a cidade capixaba Bom Jesus do Norte, ao norte do Rio Itabapoana $(\mathrm{C})$. . . . . . . . . . 134

Figura 21 - Diagrama sociométrico dos alunos, mostrando alunos representados pelas letras de "A" a "L", com setas indicando pares de colaboradores que se nominaram mutuamente . . . . . . . . . . . . . . . . . 153

Figura 22 - Sociograma de colunas, utilizado para avaliar as intensidades dos laços sociais entre pares de alunos . . . . . . . . . . . . . . . . . . . 155

Figura 23 - Representação da influência das instituições ocidentais no complexo social dos comunitários de uma vila papuásia . . . . . . . . . . . 156

Figura 24 - Rede social, direcionada, formadas por interações em um fórum de discussão online . . . . . . . . . . . . . . . . . . . . . 158

Figura 25 - Representação esquemática heurística do sistema didático e da transposição didática, promotora de pontes entre o universo reificado e o universo consensual. À direita, as redes complexas no âmbito semântico e no âmbito social, posicionadas no sistema didático e a busca por relações entre esses dois âmbitos . . . . . . . . . . . . . . . 166

Figura 26 - Detalhamento da construção da rede semântica, a partir de co-ocorrência de palavras evocadas . . . . . . . . . . . . . . . . 172 
Figura 27 - Detalhamento dos processos do Teste sociométrico de um dos critérios. Acima, a folha dos respondentes. Ao centro, as matrizes de adjacências para cada indivíduo e a matriz de adjacências do grupo. Abaixo, as redes de saída de cada indivíduo, a partir de suas escolhas e a rede social do grupo, direcionada e não pesada, para um dos critérios sociométricos 175

Figura 28 - Detalhamento do processo de concatenação das redes de todos os critérios sociométricos, originando uma rede não direcionada e com arestas tendo seu peso total considerado . . . . . . . . . . . . . . . 176

Figura 29 - Redes de similaridades para os termos evocados: Calor (A); Física (B); Ciência (C); Escola (D) e Futuro (E). Diâmetros dos vértices proporcional ao grau na rede e espessura da aresta proporcional ao índice de similaridade de Russel . . . . . . . . . . . . . . . . . . . . . . 179

Figura 30 - Redes social com arestas pesadas (acima). Heatmap da matriz de adjacências (inferior, à esquerda) e distribuição dos graus dos vértices e dos pesos das arestas (inferior, à direita) . . . . . . . . . . . . . 180

Figura 31 - Teste Scree sugerindo a retenção de dois componentes principais (à esquerda) e mapa de variáveis projetando nos dois componentes (à direita)182 


\section{Lista de tabelas}

Tabela 1 - Comparativo de algumas possibilidades do uso das redes para análise de sistemas complexos . . . . . . . . . . . . . . 120

Tabela 2 - Sumarização de atributos dos artigos retornados da revisão sistematizada na plataforma ERIC . . . . . . . . . . . . . . . . . . 127

Tabela 3 - Sumário das variáveis numéricas para todos os pares de alunos (díades)

e passos de processamento dos dados . . . . . . . . . . . . . 177 


\section{Lista de abreviaturas e siglas}

$\begin{array}{ll}\text { ARS } & \text { Análise de Redes Sociais } \\ \text { ETFES } & \text { Escola Técnica Federal do Espírito Santo } \\ \text { FEUSP } & \text { Faculdade de Educação da Universidade de São Paulo } \\ \text { GSE } & \text { Graduate School of Education } \\ \text { MNPEF } & \text { Mestrado Nacional Profissional em Ensino de Física } \\ \text { PCA } & \text { Análise de Componentes Principais } \\ \text { TRS } & \text { Teoria das Representações Sociais } \\ \text { UC- } & \text { Universidade da Califórnia em ... } \\ \text { UFES } & \text { Universidade Federal do Espírito Santo } \\ \text { USP } & \text { Universidade de São Paulo }\end{array}$




\section{Sumário}

INTRODUÇÃO $\ldots \ldots \ldots \ldots \ldots \ldots \ldots \ldots$

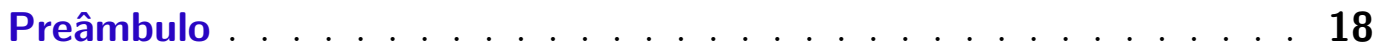

Trilha da ideia e breve memorial reflexivo . . . . . . . . . . . 25

Organização da tese . . . . . . . . . . . . . . . . 34

MÚLTIPLAS COMPLEXIDADES DA SALA DE AULA: O PROBLEMA DE PESQUISA . . . . . . . . . . . . 36

1.1 Investigações naturalizadas em da sala de aula . . . . . . . 37

$1.2 \quad$ O sistema didático e a estruturação da sala de aula . . . . . . . 41

1.3 Lógicas complementares para observação da sala de aula . . . . . . 47

1.4 Redes como possibilidades para a sala de aula . . . . . . . . . . 51

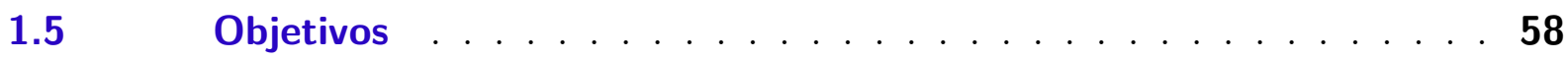

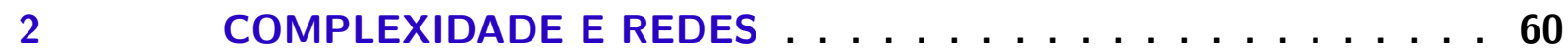

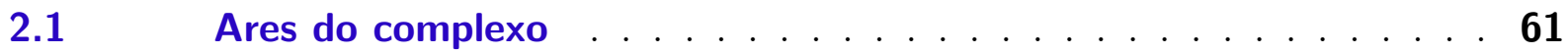

2.1.1 Composição e complexidade . . . . . . . . . . . . . . . . . . . . 64

2.1.2 Teoria Geral dos Sistemas . . . . . . . . . . . . . . . . . . . 68

2.1.3 Complexidade na síntese de unificação sistêmica de saberes . . . . . . . . . 72

2.1.4 Sistemas complexos . . . . . . . . . . . . . . . . . . . . . . 74

2.1.5 Complicado ou complexo? . . . . . . . . . . . . . . . . . . . 80

2.1.6 Complexidade em contextos microssociais . . . . . . . . . . . . . . 83

$2.2 \quad$ Mares de Redes . . . . . . . . . . . . . . . . . . . . . . . 89

2.2.1 Redes e ecologias: uma teoria da aprendizagem, reconsiderada . . . . . . 91

2.2.2 A rede como artefato e como matriz técnica . . . . . . . . . . . . . . . 96

2.2.3 Rede, informação e a amplificação dos mundos . . . . . . . . . . . . . 99

2.3 Formalizando redes: noções elementares da Teoria dos Grafos . . 110

2.3.1 Gênese da Teoria dos Grafos . . . . . . . . . . . . . . . . . . . . 110

2.3.2 Diferentes representações para os grafos . . . . . . . . . . . . . . . . 111

2.3.3 Medidas estruturais elementares de um grafo . . . . . . . . . . . 115

3 CIÊNCIA DAS REDES NA PESQUISA EM EDUCAÇÃO EM CI-

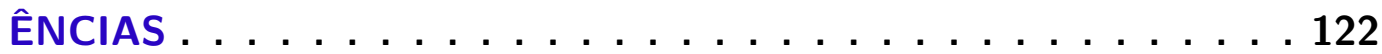

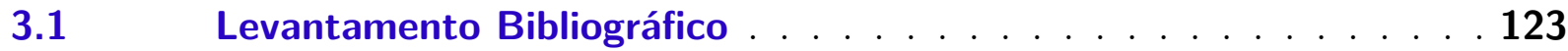

$3.1 .1 \quad$ Base de dados . . . . . . . . . . . . . . . . . . . . 123

3.1.2 Chave de procura . . . . . . . . . . . . . . . . . 123

$3.1 .3 \quad$ Filtros . . . . . . . . . . . . . . . . . . . . . . . . . 124 
3.1.4 Recorte temporal . . . . . . . . . . . . . . . . . . . 124

3.1.5 Publicações encontradas . . . . . . . . . . . . . . . . 125

3.1.6 Rede-comunidade de co-autorias do levantamento . . . . . . . . . . . 128

3.1.7 Discussão do panorama . . . . . . . . . . . . . . . . . 129

3.1.8 Considerações finais da revisão sistematizada . . . . . . . . . . . . . . . 131

4 REDES DE IDEIAS E REDES DE PESSOAS . . . . . . . . . . 133

4.1 Representações Sociais e a teia complexa de ideias . . . . . . . . . 134

4.1.1 E o povo não quis que mudassem o nome . . . . . . . . . . . . . . 134

4.1.2 Nascimento da Teoria das Representações Sociais . . . . . . . . . . . . . 136

$4.1 .3 \quad$ Processos . . . . . . . . . . . . . . . . . 140

$4.1 .4 \quad$ Dois universos . . . . . . . . . . . . . . . . . . . . 141

$4.1 .5 \quad$ Abordagem estrutural . . . . . . . . . . . . . . . . . . . 142

4.2 Redes sociais e complexidade das relações interpessoais . . . . . . 145

4.2.1 Origens da Análise de Redes Sociais . . . . . . . . . . . . . . . . . . 147

4.2.2 Análise de Redes Sociais em pesquisas em educação . . . . . . . . . . . . . 151

4.2.3 Considerações finais: busca por relações entre redes . . . . . . . . . . . . . 159

5 ESTUDO DE CASO: REDES E COMPLEXIDADE DE UMA SALA DE AUlA . . . . . . . . . . . . . . . . . . . 161

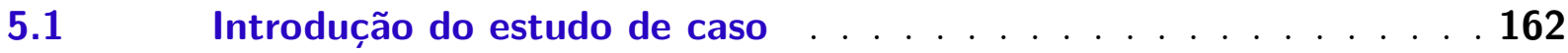

$5.2 \quad 0$ sistema didático e os dois domínios investigados . . . . . . . . 163

5.3 Material e métodos . . . . . . . . . . . . . 167

5.3.1 Contexto do estudo . . . . . . . . . . . . . . . . . 167

5.3 .2 Delineamento metodológico . . . . . . . . . . . . . . 169

5.4 Resultados . . . . . . . . . . . . . . . 178

5.4.1 Representações sociais e descrição das redes de similaridade . . . . . . . 178

5.4.2 Laços interpessoais e descrição da rede social . . . . . . . . . . . . . . . 180

5.4 .3 Redução dimensional via PCA . . . . . . . . . . . . . . . . 181

5.4 .4 Discussão dos resultados . . . . . . . . . . . . . . . . . . . . 182

5.4.5 Conclusão do estudo de caso . . . . . . . . . . . . . . . . . 187

CONSIDERAÇÕES FINAIS . . . . . . . . . . . . . . . . . . 189

Desdobramentos de ordem metodológica . . . . . . . . . . . . . . 190

Ciência das redes também para outras complexidades escolares . . . 191

Olhando adiante . . . . . . . . . . . . . . . . . 192

REFERÊNCIAS . . . . . . . . . . . . . . . . . . 194 
APÊNDICE A - INSTRUMENTO DE COLETA PARA TALP . . . 206 APÊNDICE B - INSTRUMENTO SOCIOMÉTRICO . . . . . . . 207 APÊNDICE C - REDES SOCIAIS PARA CADA CRITÉRIO SOCIOMÉTRICO . . . . . . . . . . 208 APÊNDICE D - SCRIPT EM R PARA CIENTOMETRIA . . . . 209 APÊNDICE E - SCRIPT DE R PARA ANÁLISE DAS REDES . . 212 


\section{Introdução}

A beleza da razão é que ela pode sempre ser aplicada para o entendimento das falhas da razão.

Steven Pinker

$\mathrm{E}$

STA tese cristaliza a elaboração de uma visão para a sala de aula, desenvolvida na perspectiva das redes. Nela, a lente das redes foi utilizada para refletir sobre e para investigar a complexidade das relações que configuram e que são configuradas por um grupo de jovens estudantes, diariamente reunidos para viverem seu processo de escolarização. Em sua convivência, os estudantes estabelecem laços, constroem relações, produzem símbolos e assim estruturam uma organização emergente da sala de aula.

\section{Preâmbulo}

O processo de estruturação do grupo de alunos se manifesta em diferentes dimensões de vínculo interpessoal. Embora sejam, todas essas dimensões, inerentes ao estado natural de uma sala de aula, elas não formam estruturas fechadas em si. As diferentes redes da sala de aula se sobrepõem umas às outras, se sobrepõem à realidade externa à ela e por essa realidade são também afetadas. São as diferentes formas de composição das relações que estruturam o estado natural da sala de aula que acabam por construir aquele mundo micro-, quiçá nano-, social.

Para se empreender uma investigação sobre os objetos e sobre os processos naturais de uma sala de aula, é necessário o reconhecimento de que seus acontecimentos típicos sempre se dão numa trama de múltiplas relações. São relações tanto interpessoais diretas, mediadas simbolicamente, quanto associações latentes, construídas no curso das histórias de vida dos alunos. Relações que formam um tecido de linhas que conectam os indivíduos 
e cujo entrelaçamento faz emergir de alguma organização.

As conexões e tramas formadas conferem à sala de aula sua complexidade inerente. Em sala de aula, não diferente de em outros agrupamentos humanos, cada participante é uma multitude em si, que nunca deixará de estar em interface ou em sobreposição com outras multitudes. Essas outras podem ser de mesma ordem e natureza, como outras individualidades, ou de natureza diversa como o coletivo, as instituições materiais ou virtuais, o mundo natural ou os fatos que se desdobram em sala de aula, as instâncias didáticas e outras.

Um dos desafios de se olhar a sala de aula a partir dessa complexidade de relações ali estruturadas é que a trama de tais relações pode ser manifesta ou tácita. Numa mão, são manifestas quando vemos relações interpessoais formadas em interações dialógicas, como as que ocorrem num bate papo entre as alunas e alunos. São manifestas como nas aglutinações que se formam e se transformam a cada instante. Pensemos nas conexões interpessoais formadas por declarações, verbais ou simbólicas, das preferências por um time de futebol, por exemplo. Naqueles dias em que se veem pela escola um grupo claro formado por alunos que vestem a mesma camisa. Essas são conexões que saltam aos nossos olhos. São redes que podemos agregar mesmo observadores passivos da realidade escolar. O traço cultural, manifesto nas camisas de um mesmo time, permite vislumbrar uma tecitura no grupo.

Na outra mão, são também relações tácitas. Como um caso de um par de melhores amigas ou amigos que nunca se sentam próximos em sala de aula, embora possam conviver intensamente em outros momentos. São relações existentes, embora veladas. Como colegas que venham a torcer por um mesmo time de futebol, que fazem disso inclusive um assunto dominante nas conversas de seus intervalos, mas que não cheguem à escola vestindo camisas do mesmo time. Não se pode negar igual potencial aglutinador das relações veladas. Elas tem carga histórica e podem ter compartilhamentos simbólicos menos explícitos. Mas são relações que pulsam, que estão vivas em sala de aula. No entanto, justamente por serem tácitas, a possibilidade de vê-las depende de algum interesse específico do observador. Depende de alguma provocação. 
Considerar uma sala de aula a partir de suas estruturações complexas imprime um outro desafio. Se, de um lado, essas estruturações são produzidas pelos participantes da sala de aula, emergem deles, são produtos do grupo, por outro lado elas, ao mesmo tempo, têm alguma estabilidade, mesmo que não seja perene. Por isso, conferem ao grupo alguma coesão, mesmo que frágil. Essa coesão imprime alguma restrição aos participantes, pois é ela mesma que dá forma ao grupo.

Se numa sala de aula emergem emaranhados complexos a partir das relações estabelecidas, há que se considerar que uma relação sempre depende da existência de duas entidades. Por isso, pensar a complexidade da sala de aula é sim pensar as relações, mas é também pensar os elementos, as entidades que se ligam por essas relações. As entidades locais da sala de aula podem ser identificadas por serem explícitas, como, por exemplo, o aprendiz, o educador, os materiais disponíveis, dentre outras. No entanto, não se pode negar a existência daquelas entidades locais, também estruturantes da sala de aula, mas que não são passíveis de uma observação direta, como os recursos comunicacionais acionados, os consensos formados, as noções em circulação e outras.

O ato de se considerar a complexidade de uma sala, tomando apenas os elementos que são observáveis diretamente, incorre no risco de se ignorar toda uma sorte de entidades que, interagindo ininterrupta e dinamicamente, estruturam o grupo enquanto emergem da própria estrutura do grupo. Ao se ignorar a existência e o papel das entidades mais sutis na estruturação do grupo, passa-se apenas pela superfície do ambiente, por assim dizer, ecológico da sala de aula. Não se nega o valor e a potência das observações diretas da sala de aula. Mas elas podem fazer com que as estruturações ali situadas se apresentem herméticas e estranhas.

Estruturações herméticas porque se considerarmos que o pesquisador do locus de aprendizagem é externo a ele, o máximo que será acessado prontamente é apenas aquilo que se explicita. Mesmo que se possam obter informações valiosas de uma observação e de uma participação de uma sala de aula, tal abordagem pode não capturar os processos e entidades que operam logo abaixo da superfície da observação direta, mas que são relevantes às estruturações do grupo. Não que esses elementos não possam ser trazidos à 
superfície de observação de maneira objetiva, vide toda esta tese. Entretanto, isso depende de um processo de produção de dados diferente de uma observação direta.

Estruturações estranhas porque ao pensarmos a complexidade da sala de aula, estamos considerando que nenhum de seus elementos nem nenhuma de suas relações estão desconexos de quaisquer outros, em qualquer nível de análise: o livro, o aluno, a aula, os grupos de amigos, a escola, o conteúdo estudado, a cidade, a feira de ciências, bem como quaisquer outros mais estão, em maior ou em menor intensidade, conectados. No entanto, não se pode recorrer ao que é tácito como sendo um repositório de sentidos para tudo aquilo que a observação direta não captura.

Usar o tácito como fuga para o não entendimento ou obscurantiza o pensamento ou viola o alcance da racionalidade. É fato que os participantes da sala de aula são resultados de uma imbricação complexa de tudo aquilo que neles está contido, somado a todas as relações materiais ou imateriais que por eles e entre eles são formadas. Hiperbolicamente, isso nos levaria a considerar que também os alunos são estruturações temporárias de seus órgãos e sistemas. Que esses órgãos, por sua vez, seriam estruturações temporárias de células que, por sua vez, seriam estruturações temporárias de seus átomos. Embora nenhuma dessas afirmações seja falsa e embora não possamos negar a composição daqueles que constituem a sala de aula, perdemos o radar da racionalidade se tentarmos explicar um acontecimento da sala de aula a partir das células dos alunos. A estranheza, então, decorre do fato de que, embora tudo se conecte a tudo, sem uma escolha de redução razoável, nada se pode dizer ou, num cenário pior, tudo e qualquer coisa poderia ser dito.

Isso pode ser ampliado. Qualquer sistema que possa ser caracterizados como tendo, internamente, elementos em constante interação e sendo externamente marcados por alguma fronteira, seja ela bem definida ou não, seja ela permeável ou não, incorre no risco da estranheza. Como as fronteiras de um sistema podem se sobrepor a, ou interagir com, outros sistemas, as relações em um sistema sempre podem ser pensadas como sendo interações em nível elementar - intra -, mas também interações em nível sistêmico - inter. Isso leva a uma outra característica notável: todo sistema pode ser, ele mesmo, pensado como sendo um elemento; ao mesmo, todo elemento considerado pode ser, também, um 
sistema em si.

Embora tenhamos à frente uma elaboração mais pormenorizada sobre sistemas, podemos tomar como ilustração inicial, sem a pretensão de, aqui, discuti-lo fisicamente, o caso do nosso Sistema Solar e sua organização. Ao considerarmos nossa fração do cosmos, temos cada planeta do Sistema Solar interagindo, uns com os outros, e também com o Sol. Embora nosso Sistema Solar esteja relativamente estável devido a essas mesmas interações que, a curtas distâncias e num relativamente curto tempo (numa escala cosmológica do tempo e espaço), fazem emergir a organização heliocêntrica como reconhecemos, não podemos dizer que os astros do Sistema Solar estão completamente apartados das interações com outros astros fora do sistema solar. Dessas incontáveis interações, há uma predileção local de que o Sistema Solar se mantenha organizado como está.

Entretanto, o quão ambiciosa e frustrante seria a tarefa de descrever a organização do Sistema Solar, a partir de todos os astros da Via Láctea, nossa galáxia? Quão estranha seria essa descrição? Isso não significa que uma descrição do Sistema Solar seja impossível. Temos aluma capacidade de produzir racionalidades numa descrição sobre uma série de fenômenos observáveis em nosso Sistema Solar, utilizando leis conhecidas há mais de três séculos. Para outros fenômenos, podemos lançar mão de leis físicas mais recentes e mais sofisticadas. No entanto, não somos capazes de descrever nosso Sistema Solar nem a partir da Via Láctea, nem a partir das partículas que constituem cada astro. Não pela falta de leis físicas ou de fenômenos observáveis. Mas sim por não termos uma ponte de racionalidade entre níveis tão distantes de observação que são, todos em sua própria escala de análise, inerentemente complexos.

A ilustração, tão pretensa quanto simplória, indica um dos incontáveis cenários que rodeiam nossa existência e que poderiam ser pensados como conjuntos de elementos e de relações. Nas mais diversas áreas do saber, essa estratégia é utilizada. Isso ocorre desde biólogos interessado em sistemas ecológicos, que tomam por espécies e variáveis ambientais para destrinchar o amontoado de influências mútuas de um sistema natural, ou engenheiros de telecomunicações, que utilizam outro sistema interativo, cujos elementos seriam computadores ou smartphones e cujas relações poderiam ser as ocorrências de 
trocas de mensagens, até sociólogos buscando entender as relações entre indivíduos numa comunidade ou entre comunidades num extrato mais amplo. Em todos esses casos, e em inúmeros outros que poderemos descrever à frente, busca-se um domínio dentro do qual uma racionalidade possa ser estabelecida. Uma escala na qual, mesmo sem bordas definidas, um sistema possa ser considerado e as relações entre seus elementos, mesmo as menos explícitas, podem ser avaliadas.

Neste trabalho, o alvo maior é sempre o de desempacotar alguns dos elementos e algumas das relações dos processos de estruturação que são próprios do grupo que compõe a sala de aula. Isso, sem recorrer à complexidade como a porta de fuga pela qual o poder explicador e a capacidade de análise escapam para o tácito, para o não manifesto, evitaremos os "herméticos causais" da sala de aula, representando explicitamente as relações estruturantes. Também sem recorrer à complexidade como unicidade ou completude, evitando a estranheza de se tentar explicar estruturações da sala a partir de prótons, nêutrons e elétrons. Mas buscando sim um híbrido de escalas de análise relativamente próximas, de bordas sobrepostas, que nos ajudem a entender aspectos novos do cenário das relações formadas pelos e entre os alunos. Algo que interponha as relações interpessoais de onde se salientam ideias e onde o compartilhamento de ideias retroalimenta o cenário.

Para isso, é imperativo um esforço para se produzir uma reflexão sobre a complexidade, enquanto objeto do pensamento, de modo a cercar os limites de validade de uma abordagem empírica que se valha das redes. Feito isso, as redes passam a ser a forma de olhar a sala de aula, representando suas diferentes estruturações complexas. A noção de estruturações em níveis adjacentes é particularmente interessante. Não é possível fazer sentido de um grupo de alunos em processo de aprendizagem, em sala de aula, nem partindo das células que compõe cada indivíduo e nem tampouco partindo do papel dos indivíduos na composição da biomassa da Terra, embora, novamente, tanto a primeira quanto a segunda sejam fatos. Mas é viável e possível pensarmos num agrupamento como a sala de aula, como um sistema que é complexo, que promove estruturações em diferentes escalas e níveis, do qual emergem formas de ser, de se relacionar e de pensar, dos alunos. Nisso, mais do que descrever as redes de diferentes escalas e ontologias, formadas em sala 
de aula, interessa sabermos quais são as relações que indicam uma influência mútua entre diferentes domínios considerados.

De modo semelhante, têm-se as estratégias de superação das limitações das escalas, em situações naturais. É inviável tentar explicar as células de um organismo a partir do modelo padrão de partículas elementares da Física, mesmo que não se negue a composição das células por elementos do modelo padrão. A distância, em ordens de grandeza, entre níveis de interação e de complexidade é tamanha que não se consegue racionalizar uma ponte causal ou relacional entre eles. Mas em campos de observação menos distantes, como as relações do tipo célula/órgão ou do tipo partículas elementares/átomo, avaliam-se as adjacências nas quais os sentidos, especialmente os novos sentidos, são construídos.

A partir dessa lógica, entendemos que o terreno de cultivo de sentidos para a sala de aula se situa na sobreposição de escalas próximas, ou de fronteiras difusas entre a escala do individual e a escala do coletivo. A menção a adjacências e a fronteiras difusas é feita porque as bordas que limitam níveis próximos de observação, supostamente níveis diferentes, sobretudo quando considerada a complexidade de cada um desses níveis, não são bordas claras ou bem definidas a priori.

Ao observarmos a sobreposição de escalas de sistemas tomadas como próximas sempre mal delineadas e permeáveis - é que vemos a posteriori a emergência de estabilidades e relações. Nessas estabilidades, podemos negar a consideração inicial de separação por níveis, supostamente diferentes, de complexidade. A estabilidade não caracteriza os elementos, e os elementos não caracterizam a estrutura. Uma sala de aula não é dada pela soma de seus alunos. É mais que isso.

As noções mostradas acima têm forte influência na construção desta tese. Não por um paralelismo franco e imediato entre as estruturações sociais da sala de aula e as estruturações consideradas nas ciências naturais, tipo de realismo que entendemos ser ingênuo (embora não sem precedentes) e que consideramos já estar superado no debate acadêmico. Mas sim porque reconhecemos que se quisermos fazer sentido da sala de aula, em sua complexidade e levando em conta as estruturas que dela emergem, nosso olhar precisa mirar domínios supostamente diferentes, mas que sejam de alguma forma próximos, 
quiçá adjacentes.

O interesse por investigar as redes da sala de aula, empenhando o esforço de se olhar de maneira objetiva sua complexidade inerente, esbarra em um conjunto de desafios. Desafios que são de ordem epistemológica, vista a inexistência de um programa de pesquisa abrangente e sedimentado de estudo da sala de aula a partir das redes; de ordem teórica, vista a necessidade de construção de um aporte teórico que acople frentes complementares para iluminar diferentes aspectos da complexidade da sala de aula e posicioná-los numa perspectiva de produção do saber em educação; de ordem conceitual, pois há uma polissemia da complexidade, tanto como atributo quanto como função estruturante; de ordem metodológica, vista a necessidade de escolha de um aparato técnico adequado que não se valha de categorias previamente definidas ou de hierarquias sub-somadoras, antíteses da complexidade; dentre outros.

Desafios como esses são, em certa medida, inerentes a toda investigação científica que busque pressionar as fronteiras de um campo de saber. Mas seja pela vulgarização do termo complexidade ${ }^{1}$, seja pelas indefinições das bordas não claramente delimitantes de níveis, nos parece mandatória uma cautela adicional ao invocarmos a ideia de complexidade para pensarmos a sala de aula. Isso nos leva a nos perguntarmos o que configura a complexidade de uma sala de aula, entre que níveis de complexidades emergem as saliências que podemos identificar e interpretar e como isso pode se situar no processo de ensino e aprendizagem. Essas são questões de base que devem ser pensadas como autorizadoras da nossa abordagem de investigação. Nascem nos passos da trajetória acadêmica deste pesquisador, conforme detalho a seguir.

\section{Trilha da ideia e breve memorial reflexivo}

\section{Entrada na Academia}

A gênese do uso das redes como referente da complexidade, em minha trajetória de pesquisa, se dá por dois caminhos. Primeiro, com minha primeira entrada no Mestrado

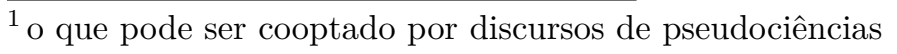


Nacional Profissional em Ensino de Física (MNPEF), na Universidade Federal do Espírito Santo (UFES). Coordenado à época pelo prof. Laércio Ferracioli, minhas interações com ele naquela virada de 2012 para 2013 foram um tanto mais frequentes que o comum, devido à oportunidade que se abrira para que eu, em 2013, pudesse vivenciar um ano sabático fora do país. Por essas interações, vem, de maneira quase informal, meu primeiro contato como ferramentas de metarrepresentação cognitiva, particularmente o "V" epistemológico de Gowin (FERRACIOLI, 2005) e os mapas conceituais de Novak (FERRACIOLI, 2007).

Essa minha primeira entrada no mestrado não se concretizou. Minha decisão fora a de abraçar a oportunidade de passar um ano em outro país, acompanhando minha esposa, no estágio de doutoramento sanduíche dela, na Universidade da Califórnia em Berkeley (UC-Berkeley). Essa decisão me aproximou do prof. Ferracioli, que me indicou a Graduate School of Education (GSE) daquela universidade, particularmente o prof. Andrea diSessa, que coordenava um grupo de pesquisa em ensino de ciências lá.

Quando em minha chegada a Berkeley procurei, sem ter nenhum vínculo institucional, o professor Andrea diSessa. A ele relatei meus quinze anos como professor de Física na educação básica e meu interesse por aprender sobre processos de ensino/aprendizagem dessa disciplina. Fui aceito por ele como visitante informal de seu grupo de pesquisa. Essa excursão de um ano a Berkeley propicia meu segundo caminho da gênese desta tese. Visitei entre 2013 e 2014 o grupo de pesquisa Patterns Group, na GSE da UC-Berkeley (DISESSA, 2013). Naquela ocasião, minha proximidade com o mundo acadêmico se consolidou e meu interesse por observar a complexidade dos processos de ensino e aprendizagem, de maneira objetiva, também.

O Patterns Group à época desenvolvia o projeto Pathways to Equitable Science Instruction Based on Culturally Common Intuitive Knowledge, no qual se propunha uma forma simbiótica de unir a pesquisa de cunho cognitivo, a partir de investigações em mudança conceitual e a pesquisa de base cultural, com estudos de conhecimentos intuitivos, incluindo assim fenômenos físicos e aspectos psicossociais.

Nesse mesmo período, frequentei a disciplina Conceptual Change, ministrada pelo prof. diSessa. Nela tive contato com uma série de artigos que remontavam tanto a linha 
histórica da dita Teoria da Mudança Conceitual, quanto os debates mais atuais e o centros de críticas que se dirigem à "primeira fase" dessa teoria. O primeiro gancho para a complexidade se deu na discussão dos trabalhos de diSessa, que utilizavam o processo de evolução conceitual como um processo dinâmico no sistema complexo do conhecimento (DISESSA, 1993; DISESSA; SHERIN, 1998). Na esteira desses trabalhos, a noção de rede é empregada para propor uma forma objetiva de se analisar a complexidade das relações causais construídas pelos estudantes em aprendizagem de Física.

De volta ao Brasil, em 2014, retorno à sala de aula, como professor do Ensino Médio e ingresso como aluno no MNPEF, agora em caráter definitivo. Esse foi um período no qual eu buscava colocar em prática aquilo que trouxera do meu período tanto como visitante no Patterns Group quanto como voluntário no museu Exploratorium (OPPENHEIMER, 1969), atividade que também exerci durante meu primeiro período na Califórnia. Essas experiências produziram em minha trajetória acadêmica duas vertentes: uma ligada ao ensino e outra ligada à pesquisa em ensino e, mais tarde, em educação.

\section{Trabalhos voltados ao Ensino}

$\mathrm{Na}$ primeira vertente, do ensino, produzi uma crítica à abordagem do Exame Nacional do Ensino Médio (ENEM) sobre uma questão de ciências da natureza e suas tecnologias que, por conta de uma concepção alternativa, levavam a um resultado absurdo, trabalho publicado no Caderno Brasileiro de Ensino de Física (RODRIGUES, 2014a). Também elaborei uma proposta de utilização de um software gratuito para gravação e edição de áudio, a ser utilizado em sala de aula, no ensino de Acústica (RODRIGUES, 2014b). Ambos foram trabalhos que empenhei em levar a público ainda antes de ter meu primeiro vínculo institucional acadêmico. A mim era claro que a construção de um pesquisador passa pelo processo institucional, mas não está limitada a suas instâncias, podendo ocorrer de maneira independente.

Durante o mestrado (2014-2016), pude desenvolver as ideias que me influenciavam. Ainda na vertente do ensino, construí de maneira embrionária dois experimentos do tipo hands-on, adaptando dois referentes, presentes no Exploratorium. Um deles consistia 
de uma série de transparência e um fundo iluminado para visualização e interação com figuras e padrões Moiré. Esse experimento era utilizado para discussão dos fenômenos de Interferência e Batimento Sonoro. O outro era uma grande plataforma pendurada em quatro cabos, que era balançada enquanto uma caneta fixa produzia num papel, preso à plataforma, figuras de Lissajous para que o conceito de oscilações amortecidas fosse discutido. Por sugestão de meu orientador de mestrado, o prof. Giuseppi Camiletti, esses dois experimentos se tornaram exibições da Mostra de Física e Astronomia da UFES, no ano de 2015.

Como a vertente do ensino é muito presente em um MNPEF, continuei a desenvolver produtos didáticos, de modo que no ano seguinte, propus uma sala de Acústica no estilo hands-on para a mostra de Física. Encampando por meu orientador, o projeto foi implementado, culminando posteriormente em uma publicação no Caderno Brasileiro de Ensino de Física na qual discutimos as potencialidades da abordagem do Exploratorium em espaços não-formais de ensino e como os visitantes reagem às exibições hands-on (RODRIGUES; TELES; CAMILETTI, 2018).

Mesmo durante o doutorado, mantive parte da minha produção acadêmica na vertente do ensino, ainda fortemente influenciado pelo modus operandi do Exploratorium. Em colaboração D. Lavino, estudante de graduação do Núcleo de Tecnologias Assistivas da UFES, construí e adaptei para software open source uma estação de produção de vídeos quadro a quadro para modelagem em ensino de Física (RODRIGUES; LAVINO, 2020), publicado na Revista Brasileira de Ensino de Física.

A cultura de "engenhocar", da qual me apropriei, me levou também a colaborações para além do âmbito exclusivo do ensino. Há, no mundo atual, um grave problema de desaparecimento de abelhas. Isso tem severos impactos ambientais, agrícolas e socioeconômicos, devido à importância da polinização na reprodução vegetal. Por isso, a convite de um grupo de pequisa em Ecologia, desenvolvi um aparato tecnológico de simulação de vibração corporal de abelhas para o estudo de polinização. Estabeleci uma parceria com o Laboratório de Mecânica de Precisão da Escola Politécnica da USP, de modo a validar o funcionamento do aparato. A construção e as formas de uso do aparato foram, então, 
publicadas na revista Ecology and Evolution (RODRIGUES et al., 2018). Esse aparato é fruto indireto de um dos experimentos que eu desenvolvera para ensino de Acústica, ainda no mestrado. Esse é um indício da importância da construção de aparatos de baixa tecnologia e de baixo custo para o desenvolvimento da sociedade.

Embora minha trajetória de produção científica esteja, em parte, cunhada em desenvolvimento de aparatos experimentais do tipo hands-on, como descrevo acima, é a outra parte desse desenvolvimento que faz brotar, propriamente, a proposta de pesquisa que no presente trabalho apresento, conforme descrevo a seguir.

\section{Pesquisa em Educação em Ciências}

É em minha outra vertente acadêmica, a da pesquisa, que se dá a origem desta tese que é tão multi-causal quanto as organizações complexas, tomadas como cerne de todo este trabalho. Se, de um lado, a vivência no Exploratorium trouxe a abordagem hands-on para minhas proposições de trabalhos, de outro é certo que meu contato com o grupo do prof. diSessa despertou interesse pelo uso das redes. Isso se deu, inicialmente, no âmbito conceitual.

Nesse âmbito, dois trabalhos dos que pude produzir, traziam um arcabouço metodológico de análise exploratória. Em um deles, foram avaliados os constructos da Teoria do Comportamento Planejado, sob as dimensões cognitiva, afetiva e conativa, em relação à Acústica, em um universo de mais de 150 alunos do ensino médio (RODRIGUES; CAMILETTI, 2015), sendo este um dos primeiros passos de pesquisa, dado no sentido de expandir o espaço dimensional de análise, evitando-se categorias a priori. Buscamos picos de saliência na distribuição dos dados para, a posteriori, analisarmos a viabilidade ou não de enquadramento das dimensões de análise escolhidas. Os resultados desse trabalho sugeriam uma relação não linear entre os dados produzidos e os construtos selecionados, dando indícios da complexidade inerente à realidade da sala de aula.

Na construção do pesquisador, o desenvolvimento de expertises em processos de análise abre possibilidades para colaborações acadêmicas. Atuei como colaborador de análise e também apresentei um outro trabalho que se valia de um processo metodológico 
semelhante ao anterior citado (FERNANDES; RODRIGUES; CAMILETTI, 2015). No trabalho, foi utilizada uma avaliação de traços latentes para analisar os aspectos motivacionais de um grupo de alunos de uma escola pública, em relação às aulas de Física. Os resultados daquele trabalho apontaram para duas dimensões relevantes em relação à motivação. Isso corroborava a literatura vigente, na qual a motivação se caracterizava por uma combinação de aspectos intrínsecos e extrínsecos, no processo escolar.

As possibilidades que um campus universitário promove para interações entre ideias e processos têm efeito que, muitas vezes, não podem sequer ser mapeados. Um exemplo disso se dá em uma aula que pude assistir, ainda no ano de 2015, no Laboratório de Estudos sobre Imagem e Cibercultura (LABIC) do departamento de comunicação social da UFES. Naquela ocasião, a discussão sobre o espaço e o tempo nas redes, e de uma ontologia das redes, conduzida pelo prof. Fábio Malini, indicava o vislumbre de proximidades valiosas entre as redes que eu tinha em mente, vindas de diSessa e as redes utilizadas como análise de um coletivo.

Naquele grupo, redes de associação de palavras eram (ainda são) utilizadas como sistema representacional de opiniões públicas e redes de co-citação de perfis em redes sociais digitais como forma representacional das relações sociais de fundo, constitutivas desse coletivo. Os processos lá utilizados permitem a detecção de padrões no amontoado confuso das publicações digitais. Há uma influência daquele evento nas propostas que desenvolvi em seguida. O grupo da comunicação social no LABIC busca minerar o cibermundo para produção de dados. Vislumbrei uma adaptação daqueles processos para testes do tipo lápis e papel, que me serviriam para investigar representações proposicionais coletivas da sala de aula.

O uso das redes complexas dava suporte à minha crítica em relação ao argumento central de uso dos mapas conceituais, em sua forma hierarquizada. O processo de organização estrutural hierárquica das associações proposicionais é, muitas vezes, utilizado como indício aprendizagem por sub-soma. Embora isso possa ser profícuo em se tratando de conceitos claramente sub-somados, como energia cinética e energia potencial sendo diferenciações de um integrados (ou sub-somador) chamado energia, ele pode ser proble- 
mático para lidar com conceitos transversais ou temas de articulação mais ampla. Neles, defendo, somente uma estruturação complexa, multi-relacionada e retroalimentada pode dar conta da produção de significado. Somente muito tempo depois eu viria a encontrar crítica semelhante no debate proposto por Ruiz-Primo e Shavelson (1996), que apontam a tensão existente entre a visão hierárquica da memória associativa, de David Ausubel, e a visão de uma memória associativa na forma de redes complexas, de James Deese, e como isso pode ser problemático na utilização de mapas conceituais como ferramenta de avaliação da aprendizagem.

Alinhado à visão das redes complexas, produzi uma versão de redes semânticas de associações, feitas por um grupo de alunos do Ensino Médio, e ensaiei um modelo de análise, não apenas para os indivíduos, mas para o coletivo, concatenando as redes individuais (RODRIGUES; CAMILETTI, 2017). Naquele trabalho, a rede coletiva, de um grupo de 41 alunos, é produzida para indicar consensos formados acerca de Acústica. Meu afastamento das formas de uso tradicionais dos mapas conceituais então era visto, primeiro pela minha crítica às hierarquizações conceituais, depois por meu interesse em se utilizar formas de representações coletivas, para além das individuais.

O ensaio de análise feito naquele trabalho foi refinado e serviu para construção de redes semânticas na investigação do processo de evolução conceitual do grupo. Em uma pesquisa que combinava diferentes formas de produção de dados, como psicometria e indicativos de auto-eficácia, também as redes semânticas de associação feitas pelos alunos foram utilizadas em sua forma explícita imagética (ou grafos, como veremos mais à frente) para avaliação, tanto da modificação das estruturas complexas formadas, quanto para avaliação das medidas estruturais desses grafos em relação aos demais indicadores. Os resultados daquela pesquisa, publicados na revista Investigações em Ensino de Ciências (RODRIGUES; CAMILETTI, 2018), indicaram um processo de evolução conceitual mais próximo a um modelo ecológico do que de a um modelo disruptivo, corroborando uma mudança conceitual mais semelhante a sua forma reconsiderada, que inclui a complexidade, do que a sua forma original, conforme detalharemos mais à frente, nesta tese.

Esses resultados apontavam um aumento na complexidade das associações à medida 
que os alunos articulavam mais e melhor sobre os conceitos trabalhados. Mas eram as redes sobrepostas, indicadoras do coletivo, que apresentavam características novas. Algumas relações eram repetidas por muitos alunos, isto é, algumas relações proposicionais eram feitas sistematicamente pelo grupo. E, embora sem dados objetivos para dar suporte, eu conhecia meus alunos, sujeitos de pesquisa daquele trabalho, e eu sabia que muitos colegas que pareciam mais próximos, acabavam por produzir mais consensos na rede. Daí, novas perguntas surgiram daquela pesquisa. Qual seria o mecanismo da formação desses consensos naquelas redes? Além dos mecanismos cognitivos, quais seriam os mecanismos sociais por trás daqueles resultados?

Na busca por perspectivas teóricas que pudessem iluminar essas redes coletivas, a Teoria das Representações Sociais se mostrou um complemento fundamental. Mas não suficiente. Embora dê conta dos aspectos psicossociais e explique a lógica interna das representações e, de maneira valiosa, as trate como fenômeno da vida social, aspectos interpessoais ainda careciam de uma perspectiva. Então, as redes sociais pareciam uma forma de explorar a interpessoalidade para que, combinadas às redes socio-semânticas, pudessem apresentar uma forma nova de ver a sala de aula.

Meu interesse pelo tema complexidade, me fez ir a uma busca online, pela qual chegar à disciplina ofertada pelo prof. Maurício Pietrocola na Faculdade de Educação da USP (FEUSP), intitulada Ensino, Aprendizagem e Cultura Didática: Complexidade Escolar e Análise Multi-Lógica. Eu tinha a complexidade conceitual como pano de fundo de minhas publicações anteriores. Pareceu-me uma excelente forma de dar sequência àqueles estudos, ir trabalhar junto ao prof. Pietrocola, que já havia composto minha banca examinadora de dissertação de mestrado. O seguimento se mostrou profícuo: a perspectiva multi-nível e multi-teórica que Pietrocola utilizava, ajudava a resolver o problema de se tomar partes de visões para compor uma interpretação daquilo que é complexo. Além disso, um compartilhamento da visão de que as redes são uma abordagem maior que uma ferramenta unicamente metodológica, promoveu uma aproximação acadêmica que se transformou numa relação de orientação.

Nessa relação, junto a A. Borges, estudante de graduação e aluno de iniciação 
científica, fomos a campo e investigamos, numa perspectiva psicossocial, as representações de licenciandos em Física sobre a utilização da História da Ciência como abordagem de ensino. Os resultados dessa pesquisa culminaram no trabalho publicado na revista Journal of Physics: Conference Series (RODRIGUES; BORGES; PIETROCOLA, 2019). Nesse trabalho, vimos a formação de núcleos figurativos que colocavam a história da ciência apoiada em elementos factuais, como pessoas e acontecimentos além de, principalmente, como fator de contextualização do ensino. Isso fora indício de que a história da ciência é vista mais como ferramenta do que como processo de construção do conhecimento da Física, por parte daqueles licenciandos.

Como minhas produções, até então, voltavam-se sempre ao âmbito cognitivo ou representacional, a inclusão do aspecto social se fazia necessária. Produzimos um protótipo de análise (RODRIGUES; PIETROCOLA, 2019), no qual o aspecto estritamente interpessoal foi considerado, e uma rede social fora construída, a partir de um critério sociométrico. Esse ensaio apontou uma outra necessidade: a de sobreposição das redes sociais e das redes semânticas. E isso demandaria novas formas de análise.

Meu segundo período de visita à Graduate School of Education da UC-Berkeley ocorre entre 2018 e 2019. Desta vez, sob o vínculo institucional de meu Estágio Sanduíche de doutoramento. Fui recebido, novamente, pelo prof. diSessa. Encaminhado por ele, pude também interagir com o prof. Geoffrey Saxe, que utiliza a análise de redes em uma perspectiva próxima à que eu propunha, algo que trouxe uma contribuição nova para este trabalho.

A ideia proposta por Saxe, de se avaliar as díades formadas na rede, foi influenciadora de nosso modelo de análise. Descrevemos, dentro do sistema didático, como as díades nas redes sociais dos alunos se relacionam com a emergência de consensos nas redes sociosemânticas dos alunos e como isso funciona como ponte entre o mundo representacional e o mundo interpessoal. Os resultados desse acoplamento culminaram em uma publicação na revista Education Sciences (RODRIGUES; PIETROCOLA, 2020), que corresponde ao estudo de caso, parte empírica desta tese, conforme apresentaremos a diante.

Essa trajetória, brevemente aqui remontada como forma de localizar a pesquisa e o 
pesquisador, ao leitor, tem seu clímax na construção do presente trabalho, tese na qual selecionamos bases teóricas, perspectivas filosóficas e fundamentos metodológicos que nos permitam utilizar as redes para produção de saber sobre a sala de aula. Então, de maneira sumarizada, apresentamos a seguir a organização estrutural deste documento.

\section{Organização da tese}

Este trabalho está organizado em Capítulos, nos quais mostramos nossas visões das redes, consideradas como referentes da complexidade da sala de aula, em diferentes vieses. No Capítulo 1, discutimos como os avanços na pesquisa educacional em sala de aula, sempre se valem de avanços outras áreas do saber. Relembramos o caso da influência dos estudos etnográficos, que são trazidos para a sala de aula e que promovem um novo momento nos estudos situacionais de ensino. Argumentaremos que um novo momento da produção de saber sobre a sala de aula pode se dar pela observação de suas redes.

Partimos desse ponto para problematizarmos a característica da pesquisa educacional, de ter seus avanços ligados aos avanços de outras áreas disciplinares (Seç. 1.1). Então, consideramos o aspecto constitutivo da estruturação da sala de aula, na perspectiva do sistema didático de Yves Chevallard (Seç. 1.2). Sua característica relacional implica complexidades, em diferentes domínios de observação. Para lidar com as diferentes complexidades da sala de aula, há uma necessidade de se combinar olhares complementares sobre ela (Seç. 1.3). Declaramos então nossa proposta de uso das redes como artefatos de exploração de tais complexidades e mostramos nosso afastamento de seus usos determinísticos ou como perfiladores de indivíduos (Seç. 1.4) para, então, apresentamos os objetivos geral e específicos desta tese (Seç. 1.5).

O Capítulo 2 é utilizado para construção de um território de noções sobre a complexidade e sobre as redes. Em sua primeira parte, visitamos alguns dos fundamentos do pensamento sobre sistemas, bem como visões sobre aqueles sistemas, ditos, complexos (Seç. 2.1). Então, na Seção 2.2 agregamos um aporte filosófico para o pensamento das redes, discutimos seus usos, tanto enquanto estrutura de pensamento, quanto como ferramenta 
metodológica, colocando as redes como uma alternativa à dominância das abordagens semióticas. A parte final do capítulo (Seç. 2.3) é destinada à apresentação de fundamentos da Teoria dos Grafos e como essa teoria permite a formalização e a representação das redes.

No Capítulo 3, procedemos uma revisão sistematizada, mapeando o panorama do uso da ciência das redes no panorama global da pesquisa em educação científica e indicamos, por uma rede cientométrica, revistas e grupos de pesquisa nos quais os trabalhos parecem se aglutinar. Em seguida, no Capítulo 4, apresentamos bases teóricas de dois domínios de interesse deste trabalho. Num deles (Seç. 4.1), a complexidade do domínio das ideias compartilhadas em sala de aula é tratada dentro da perspectiva da teoria das representações sociais, de Serge Moscovici, e as redes remetem a uma das abordagens, a estrutural, dessa teoria. No outro (Seç. 4.2), a complexidade da organização interpessoal da sala de aula é tratada na perspectiva sociométrica de Jacob Levy Moreno, em sua versão atualizada e as redes são redes sociais, das quais emergem afiliações e pelas quais as representações são produzidas.

Na última parte desta tese (Cap. 5) retomamos os principais fundamentos apresentados e apresentamos um estudo de caso procedido, no qual redes semânticas e sociais foram construídas a partir de dados empíricos de um grupo de alunos do Ensino Médio, em aulas de Física. Esse trecho também é destinado à apresentação detalhada da metodologia utilizada, bem como do processo computacional de análise, desenvolvido para o estudo. Os resultados do estudo de caso realizado mostram redes tanto da complexidade representacional, quanto da complexidade social e permitiram a análise da interdependência da força das ligações interpessoais dos alunos e da produção de consensos em sala de aula. 


\title{
1 Múltiplas complexidades da sala de aula: o
}

\section{problema de pesquisa}

\begin{abstract}
A patologia moderna da mente está na hipersimplificação
\end{abstract} que não deixa ver a complexidade do real.

Edgar Morin

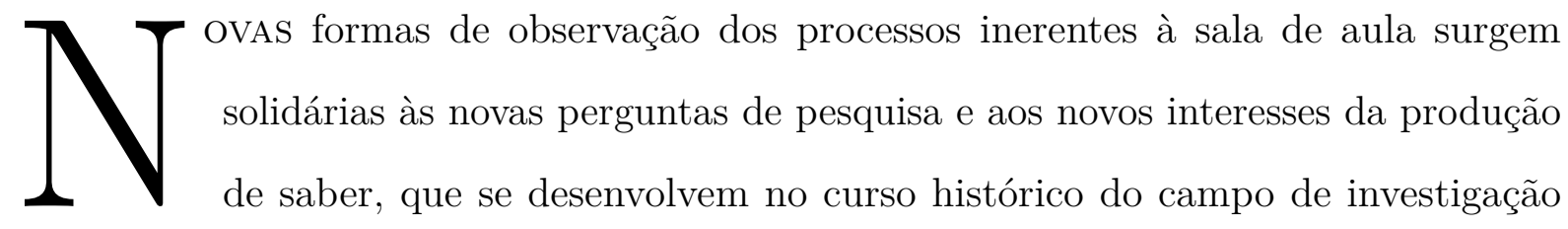
educacional. Uma característica inerente à pesquisa educacional é que as investigações dos processos de escolarização dependem de outras ciências que fornecem, tanto o aparato metodológico da pesquisa quanto as ferramentas intelectuais de sua concepção. A sociologia, a psicologia, a antropologia e a linguística, dentre outras ciências disciplinares, cujos campos são bem definidos, emprestam suas verdades para que entendamos os variados aspectos da sala de aula. E essas verdades vão além dos métodos: importamos visões das diferentes áreas do saber, que se ocupam do ser humano e de seus processos, para pensarmos os aspectos inerentes à escola e ao processo educacional, sejam eles o desenvolvimento, a participação numa comunidade, a ação, o discurso, a produção de cultura, a aprendizagem ou outros. De tanto, Macbeth (2003) pontua que e a maioria das inovações, na pesquisa educacional ocorre com o uso de outras ciências disciplinares, trazidas para o pensamento do processo educacional.

Em grande medida, é o reconhecimento da afirmação acima que impulsiona o presente trabalho. Tanto na construção do aporte teórico, quanto na escolha da proposta metodológica, a contribuição que intentamos legar com este trabalho se dá no fato de abarcarmos saberes de outras áreas, particularmente da psicologia social e da matemática 
discreta, como mostraremos à frente. Entendemos ser um fato que, com o desenvolvimento de campos contemporâneos do saber, no presente caso, o de uma ciência multidisciplinar das redes complexas, encontramos um suporte que impulsiona a proposição de uma forma peculiar de observação da sala de aula e de uma reflexão sobre sua complexidade.

Isso significa que, com o recente desenvolvimento do aparato teórico e metodológico das redes, a própria investigação em educação ganha novos desenhos, tomando formas de análise de outros campos e, com isso, ganhando poder explicatório para evidências e fatos da sala de aula que pelas abordagens de outrora, não poderiam ser capturados. Mas para que o uso das redes seja minimamente delimitado, é necessário entender os aspectos que o separa de outras formas de investigação da sala de aula.

\subsection{Investigações naturalizadas em da sala de aula}

As mudanças das formas de observação da sala de aula, via de regra, estabelecem seus métodos a partir de uma crítica a alguns dos aspectos das abordagens e dos estudos vigentes. Assim, novas abordagens miram novos objetos, que levam a novas perguntas. Esse processo sempre marca os períodos de transformação da pesquisa educacional. Um exemplo desse movimento de mudança pode ser visto na, já clássica, obra de Mehan (1979). Vindo de uma formação em sociologia, Mehan apresenta uma crítica aos estudos correlacionais de grande envergadura, que eram o status quo à época da publicação de seu livro. Os estudos correlacionais estariam interessados em avaliar a influência de alguma variável ligada à escola e/ou ao processo de escolarização na vida do estudante.

Naquilo que Mehan chama de ironia metodológica, tinha-se a contradição de que tais estudos se proporiam a investigar a influência da escola na vida dos estudantes, mas seus métodos característicos acabariam por lidar com variáveis (supostamente, incluímos) independentes, na forma de dados de entrada, e observariam então as variáveis dependentes a partir dos dados de saída. Ironicamente esse processo se presta a entender o que a escola produz na vida dos estudantes - i.e. busca entender a escola - mas termina por colocar a escola como uma caixa-preta, situada entre esses dois conjuntos de variáveis. 
Um dos pontos do argumento de Mehan, com o qual concordamos, é o de que ao se pensar o aluno e suas realizações profissionais/econômicas como sendo fruto apenas de fatores do ambiente, externos a ele, invoca-se o princípio da tábula rasa. Dessa forma, seria como se o processo escolar exercesse um tipo de imposição, vinda do topo e que determinaria os desdobramentos das vidas dos estudantes. Nos parece claro que pensar o aluno como uma página a ser preenchida e ainda determinado e constrangido por fatores ambientais, significa ignorar o papel, a agência, a potência dos próprios alunos como transformadores de suas realidades. Significa ignorar que os alunos podem ser promovedores de mudanças nas mesmas estruturas que os estudos correlacionais de grande envergadura detectariam como sendo monolíticas e impositivas.

Embora a crítica de Mehan utilize o argumento de oposição ao determinismo, ela não nega a influência da escola na vida dos estudantes. Mas faz um chamado para que o olhar da pesquisa educacional se direcione à sala de aula, de modo que o elemento "escola" possa ser compreendido também na perspectiva bottom-up (de baixo acima).

Por isso, é pela investigação dos e nos loci de ensino e aprendizagem que visões determinísticas sobre vida do estudante podem ser superadas. Essas visões a serem superadas iriam desde o determinismo genético, no qual a chance de sucesso do estudante seria um resultado de sua hereditariedade, passando pelo determinismo ambiental, no qual o processo educação se reduziria a uma função compensatória às dificuldades de sucesso profissional e econômico dos estudantes e também o determinismo das experiências de primeira infância sobre as experiências escolares dos aluno.

Embora nós tenhamos mais à frente a oportunidade de pormenorizar nossa visão anti-determinística dos acontecimentos escolares, algo que nos aproxima da visão de Mehan, sua crítica aos determinismos na pesquisa escolar é utilizada como ponto de partida para a proposição de sua metodologia, que é diversa da nossa, mas que oferece grande força explicativa: o uso de uma etnografia constitutiva como forma de descrever organizações sociais das rotinas, eventos cotidianos.

Isso contrastava com duas correntes estabelecidas à época de sua obra Learning Lessons, à qual nos referimos. De um lado, quanto aos estudos correlacionais era pertinente 
a crítica de que transformavam a escola em uma grande interrogação. Em outro ponto, a crítica se dirigia a uma corrente que se ocupava de uma outra forma de investigação interacional dos alunos, em sala de aula. Flanders (1968), por exemplo, utilizava uma matriz de características discretas de análise interacional.

Mesmo que ambos os autores estivessem interessados em investigar acontecimentos da sala de aula, o método de Flanders também recebia críticas de Mehan sobretudo pelo fato de que Flanders usava sua matriz de categorias discretas para avaliar interações verbais. E isso não iluminaria o papel das interações não-verbais nem a função da linguagem ou as contribuições dos alunos para as interações da sala de aula.

A posição de Mehan, a nosso ver, não diminui o potencial informativo do sistema de análise de Flanders. Mas explicita o fato de que a complexidade da sala de aula é tamanha tal que qualquer que seja a abordagem interessada em olhá-la em seu estado naturalizado, irá esbarrar em limitações metodológicas. Essas limitações habilitarão o pesquisador a observar um conjunto sempre limitado de aspectos. Não havendo metodologia privilegiada, diferentes aspectos da sala de aula só se tornam visíveis a partir de diferentes lentes de observação.

A escolha de Mehan para observação da sala de aula tem uma influência declarada de Durkheim (1896) e de sua visão para a organização social. A estruturação da sala de aula, pensada no sentido durkheimniano, seria então um processo dos fatos sociais. Um processo de distribuição de organização social com alguma coerção dada pelos papeis sociais dos atores envolvidos. A organização e o reestabelecimento de alguma ordem social, em sala de aula, dependeria, então, de trabalho interacional.

Desse quadro, a contribuição que entendemos ser a mais marcante de Mehan é produzida: a observação dos ciclos IRA (iniciação, resposta e avaliação) como elemento estruturante da organização social da sala de aula. A avaliação (A), no ciclo IRA, pode assumir papel de anuência, desencadeando o processo interacional, ou de sanção, caso um aluno viole a ordem social estabelecida pela distribuição dos turnos de fala, feita pelo professor. E, em casos de sanção, trabalho interacional é demandado para reestabelecimento da ordem social. 
O movimento que Mehan faz ao invocar a ironia metodológica dos estudos relacionais e as limitações linguísticas das categorias discretas ocorre no sentido de defender sua etnografia, que incluía aspectos multimodais da comunicação. Defende assim, de maneira explicita, sua metodologia e sua abordagem de pesquisa pela explicitação daquilo que outras não capturam.

Há uma vantagem em se levantar tais críticas, pois traçam-se mais facilmente as fronteiras entre diferentes posições epistemológicas. No entanto, o que remanesce como pergunta é: existiria alguma abordagem da pesquisa educacional livre de suas próprias ironias metodológicas? A nosso ver, qualquer resposta positiva a esta pergunta carregará uma ilusão de existência de uma abordagem de pesquisa que seja privilegiada.

Tal ilusão se apoiaria em outra ainda mais de base: a de que alguma abordagem de pesquisa seria capaz (ou estaria mais próxima) de capturar o todo da sala de aula. E essa última, inevitavelmente, nos retorna a dois pontos abordados acima e intimamente relacionados. Um deles é de que a complexidade inerente a cenários reais, como agrupamentos humanos, como a sala de aula, se dá em múltiplas e incontáveis dimensões e sobreposições. O outro é que a produção de saber sobre a sala de aula, assumindo que uma abordagem específica de pesquisa teria lugar privilegiado no sentido de capturar o todo, significa a tentativa de produzir saber acerca do todo restringindo suas partes, o que remete ao determinismo, que nomearemos mais à frente por determinismo estrutural.

Não nos parece, em nenhum senso, que Mehan invoque determinismos em sua proposta. Mas fazemos esse alerta até para nossa própria orientação em relação à abordagem que escolhemos. Vemos que o valor de se olhar para a sala de aula numa abordagem etnográfica, seja na perspectiva dos ciclos IRA, seja em outra, é inegável. Como também inegável o valor que se tem ao observar as nuances que a semiótica permite detectar, pelas análises dos multi-modos da comunicação.

No entanto, localizaremos nossa abordagem fazendo um contraponto a Mehan em três desdobramentos limitantes: $(i)$ os ciclos IRA elucidam cadeias de interações discursivas indivíduo/indivíduo, o que limita a observação das relações indivíduo/grupo, bem como relações grupo/indivíduo; $(i i)$ as configurações proxêmicas de uma sala de 
aula, tipicamente centradas no professor, omitem aspectos das afiliações interpessoais dos alunos, muitas vezes não manifestas explicitamente nas interações verbais ou em outros modos de comunicação, embora sendo elemento estruturante, fincado na história de relações dos participantes do grupo; e (iii) a dinâmica IRA não captura elementos de representações simbólicas que circulam no coletivo e que conferem identidade a ele e, desse modo, não mostram os compartilhamentos carregados de valor simbólico e validados pelos participantes.

É importante declararmos que essa nossa leitura não é um apelo ao viva e deixe viver na pesquisa situada em sala de aula. Nosso movimento nesta exata seção é também um movimento de apresentação dos nãos da nossa proposta, para construirmos uma borda minimamente visível da nossa posição epistemológica nesta tese. Nossas redes funcionam mais como uma complementariedade ao império da semiótica ${ }^{1}$ do que como uma oposição a ele.

Em nossa escolha, complementar às limitações apresentadas acima, buscamos formas de representar explicitamente, mesmo que sabidamente sempre em parte, as estruturações complexas da sala de aula. Assim, podemos observar, no complexo estrutural, traços das relações indivíduo/grupo e das produções de consensos, geradores de representações que circulam entre os participantes. Isso, no intuito de produzirmos evidências a partir das quais seja possível inferir a existência ou não de pontes entre as redes do mundo interpessoal e as redes do mundo representacional, buscando entender o intrincamento desses mundos.

\subsection{O sistema didático e a estruturação da sala de aula}

Adicionamos aos posicionamento apresentados acima, uma necessidade de situar as estruturações formadas em sala de aula, que investigaremos nesta pesquisa, como sendo parte do processo didático. Mas para isso precisaremos, antes, situar uma visão sobre a didática que considere diferentes dimensões do ensino. Essa inclusão remete à mudança

$\overline{{ }^{1} \text { no sentido dado por Latour e Hermandt }}$ (2013), que abordaremos no Capítulo 2, Item 2.2.3 
de pensamento sobre o processo de ensino e aprendizagem que ocorreu quando o enfoque clássico da didática, centrado no binário professor/aluno (GASCÓN, 1998) deixou de ser suficiente para o entendimento dos processos reais da sala de aula.

Gascón (1998) ressalta que a didática clássica se voltava ou $(i)$ à aprendizagem do aluno, tendo como objeto primário de pesquisa o conhecimento (matemático, no caso discutido pelo autor) do aluno e seu desenvolvimento e tendo estudos que se fundamentavam explicita e exclusivamente numa abordagem psicológica; ou (ii) à atividade docente, interessada no processo de instrução e considerando a formação do professor, tendo estudos que fundamentavam no pensamento do professor, seus conhecimentos disciplinares específicos e seus conhecimentos didáticos.

Criticados por Gascón (1998), os enfoques da didática clássica pecariam por, primeiro, reduzir os conhecimentos disciplinares específicos (da matemática, no dele) a saberes imutáveis e inquestionáveis; a saberes que o professor deveria aprender para então ensinar; depois, por reduzirem o enfoque no binário aluno/professor a um enfoque exclusivamente psicológico; e ainda por reduzir o saber didático a um saber técnico.

No sentido de ampliar a problemática da didática, levando-a além das reduções que o olhar exclusivamente binário entre professor e aluno, encontra-se no sistema didático (CHEVALLARD, 1991) a inclusão do saber como um terceiro elemento inerente. Entretanto, um saber que não opera como elemento imutável ou inquestionável. Um saber que assume diferentes formas e que atende a diferentes funções, dependendo de sua localização institucional.

Para Chevallard (1991), a inclusão do saber no sistema sugere não apenas a existência dos três polos de interesse - os estudantes (les élèves), a/o professora(o) (l'enseignant) e o saber ensinado (le savoir enseigné) - que podem ser representados esquematicamente conforme a Figura 1. Mas com esses polos, tem-se um sistema que, quando em análise, pode ser observado por suas relações. 
Figura 1 - Representação esquemática do sistema didático. Os estudantes (les élèves, E), a/o professora(o) (l'enseignant, P) e o saber ensinado (le savoir enseigné, S)

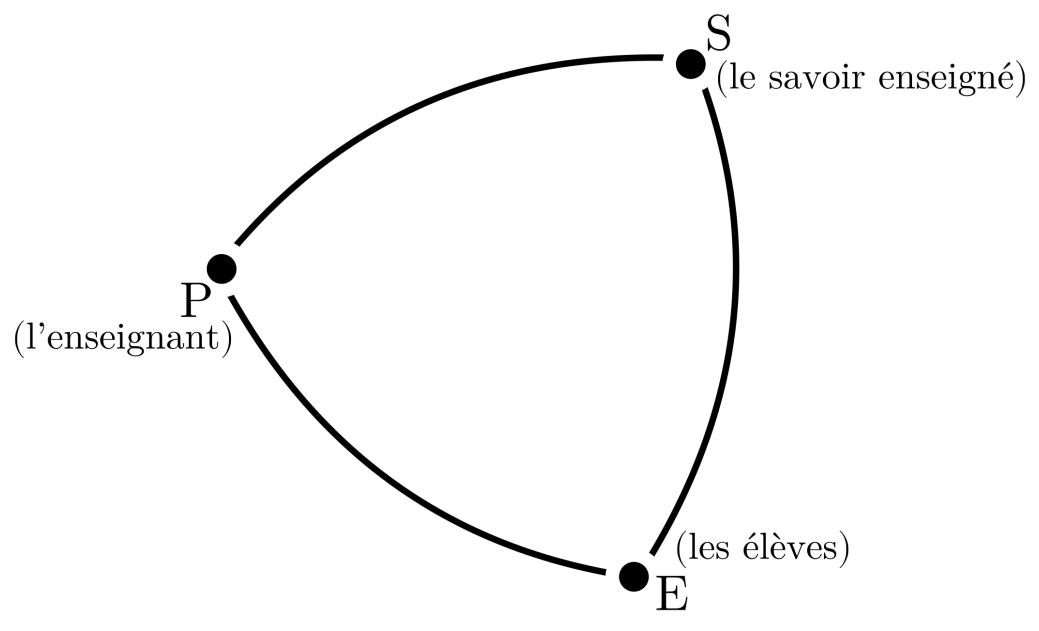

Fonte: elaboração nossa, adaptada de Chevallard (1991).

As relações do sistema são processos que se completam dois a dois, em diferentes dimensões:

Dimensão sociológica: a relação professor/alunos $(\mathrm{P} \leftrightarrow \mathrm{E})$ é onde o ato de ensino toma forma. É, possivelmente, nesta aresta que os ciclos iniciação-resposta-avaliação (IRA) de Mehan podem ser mais frequentemente identificados. O papel do professor na organização social da sala ganha forma de ações docentes, pelas distribuições dos turnos de fala, configurando os fatos sociais, de Durkheim. Onde o trabalho interacional é ativado para criar e reestabelecer a ordem social.

O esquema do sistema didático acima também nos ajuda a pensar a sala de aula em sua natureza assimétrica, como a vemos. Essa assimetria é vista pelo uso de singulares e plural em seu esquema: o saber e a/o professora(o), singulares, e os estudantes no plural.

Mesmo se pensarmos em um ambiente de estudos que seja democrático, no qual o professor opte por diminuir a assimetria de sua posição em relação aos alunos, sua centralidade não pode ser ignorada. Institucionalmente, é ao professor que cabem responsabilidades sobre o grupo com o qual ele está trabalhando. Responsabilidades essas de ordem humana, social e epistêmica. Nossa leitura é de que o fato de o professor ser colocado, sozinho, como um dos vértices do sistema didático não é uma defesa de Chevallard a 
ambientes de ensino professorcêntricos. Mas é a de não ignorar o papel institucional do professor nas relações didáticas estabelecidas em sala de aula.

Dimensão epistemológica: a relação professor/saber $(\mathrm{P} \leftrightarrow \mathrm{S})$ é aquela na qual as decisões do quê ensinar são tomadas. É nessa aresta que ocorre o processo de transposição do saber que é produzido no contexto profissional da ciência. Saber que Chevallard caracteriza como saber-sábio. Essa primeira transposição é executada pelo professor, em um âmbito institucional. Dessa etapa, resulta um saber a ser ensinado. Este sim, presente em um dos vértices do sistema.

Proceder essa transposição é diferente de produzir uma simplificação. Não se trata de considerar o saber-sábio um saber a ser alcançado e que seria transformado em um saber mais simples. Valendo-se desse princípio chevallardiano para pensar a transposição de saberes da Física Moderna para o Ensino Médio, Brockington e Pietrocola enfatizam "[...] o quanto a transposição dos saberes científicos para a sala de aula induz a uma idéia de simplificação, de que, ao se ensinar Fúsica no Ensino Médio, tem-se apenas um processo onde o cerne é 'tornar mais simples' conceitos complicados" (BROCKINGTON; PIETROCOLA, 2005, p. 390). Os autores pontuam que o saber a ser ensinado não é uma versão simples do saber-sábio, mas sim um saber que tem um estatuto epistemológico diferente; se torna, então, um saber escolar.

Dimensão psicológica: é na aresta saber/estudante $(\mathrm{S} \leftrightarrow \mathrm{E})$ que se desdobram os processos de interposição entre o saber a ser ensinado, que já estaria transposto para sua função didática, e aquilo que os estudantes tomarão para si. Para Chevallard, esse saber que os estudantes tomam para si, um saber aprendido, não seria uma repetição do saber acadêmico pois "[...] na intimidade do funcionamento didático, [o conhecimento] cumprirá uma função inteiramente diferente: de reprodução e de representação do saber, sem estar submetido às mesmas exigências de produção." (CHEVALLARD, 1991, p. 25, tradução nossa).

Tal diferença nos indica que o saber a ser ensinado, já transposto do saber-sábio, reverbera entre os estudantes como uma outra esfera de saber. E, por não mimicar a produção de saber, o conhecimento aprendido teria tanto elementos e processos vindos 
da produção acadêmica do conhecimento, mas também seria marcado por adaptações movidas pelo processo de transposição que o professor propõe. Além de outras adaptações ocorridas no processo de compartilhamento das ideias e na produção de representações, pelos estudantes.

Quando consideramos a transposição esquematizada por Chevallard, vemos que saber escolar é materializado na instância institucional dos sistemas de ensino. Embora seja um saber diferente do saber profissionalmente produzido no âmbito da ciência, aqueles saberes a serem ensinados, em suas diversas áreas de existência, bem como aquilo que os alunos tomam pra si, o saber aprendido, estão em constante interface com os saberes-sábios a que se referem. Isso porque os diversos sistemas didáticos formados no ambiente escolar não estão nem separados de, nem alheios a seus entornos societais.

Os entornos societais dos sistemas didáticos não são compostos apenas pelos grupos profissionais de produção do saber-sábio. Toda a expressão de pensamento, vindo de todos os atores pensantes que desenvolvem visões sobre a ciência, sobre a escola e sobre os próprios saberes estão em interação. Da multitude desses atores emergem incontáveis acordos e também conflitos.

Essa esfera de pensamento do mundo representaria a noosfera. Esse é um termo que Chevallard declara parodiar, possivelmente de Teilhard de Chardin (2008) que cunha a noção de noosfera para se referir à camada de pensamento existente por fora e por cima da biosfera ou de Vernadsky (1945) para quem a noosfera seria o último de muitos estágios de evolução da biosfera.

A composição do entorno societal dentro do qual os sistemas de ensino são, engloba diferentes sistemas didáticos. Cientistas, pais, diretores, políticos, alunos, comerciantes e toda entidade aderente à esfera de pensamento do mundo influenciaria o processo de transposição do saber-sábio para o saber a ser ensinado na escola. E dentro desses sistemas de ensino, os diferentes sistemas didáticos se estabeleceriam, conforme esquematizado na Figura 2. 
Figura 2 - Representação esquemática da relação entre os conhecimentos do mundo e os sistemas de ensino e didáticos

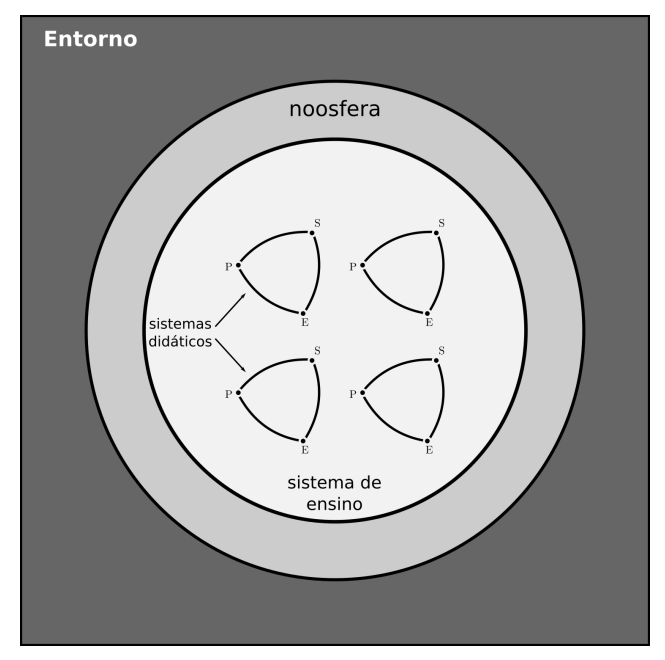

Fonte: elaboração nossa, adaptada de Chevallard (1991).

Nosso interesse é o de investigar relações do processo didático, naturalmente estruturadas em sala de aula. Optamos por investigar relações localizadas na aresta saber/estudante $(\mathrm{S} \leftrightarrow \mathrm{E})$ do sistema didático. $\mathrm{O}$ vértice $\mathrm{S}$ se refere ao saber a ser ensinado. Estamos interessados em olhar como esse saber permeia o universo representacional dos alunos e como os elementos do saber ensinado coexistem com elementos do cotidiano dos estudantes, formando um saber aprendido que é híbrido entre o científico e o não-científico, emergindo como redes representacionais.

As formas de saber, compartilhadas pelos alunos, são complexos de conhecimento que acomodam sobreposições das noções aceitas pela comunidade científica e das noções trazidas das vidas dos estudantes. Elas incluem consensos e idiossincrasias. São, como mostraremos à frentes, representações simbólicas que dão cola social ao grupo de alunos. Esses, no vértice E, formam um complexo de relações interpessoais que são, por sua vez, estruturantes sociais do grupo de alunos. Essas estruturações sociais do grupo de alunos da sala de aula, ao mesmo tempo que dá forma às representações compartilhadas, são promovidas por elas.

$\mathrm{Na}$ aresta $\mathrm{S} \leftrightarrow \mathrm{E}$ podemos ter um um equilíbrio razoável entre nossa ambição de explorar a complexidade da sala de aula. É ali que temos níveis adjacentes de complexidades. 
Por isso, é ali que temos algum afunilamento a ponto de tornar viável uma construção de sentidos sobre a complexidade estrutural da sala de aula. Mas um afunilamento não reducionista nem linearizador do um ambiente multifacetado que é a sala de aula.

Se, de um lado, o sistema didático nos permite localizar a reflexão central desta tese, de outro, ainda nos parece necessário encontrar lentes que sejam adequada para investigação da complexidade inerente aos dois vértices do sistema didático, bem como das relações entre as estruturas quem emergem desses vértices. Para isso, buscaremos acoplar duas formas diferentes, mas complementares, de observação da sala de aula. Isso permitirá a produção de resultados na forma de representações explícitas tanto das estruturações sociais na trama interpessoal dos alunos, quanto das emergências de representações simbólicas que são compartilhadas por eles e que circulam entre eles. Mas o cumprimento dessa tarefa demanda a utilização de mais de uma forma de mirar a sala de aula.

\subsection{Lógicas complementares para observação da sala de aula}

Para nossa abordagem de investigação da sala de aula, queremos aproximar as emergências estruturais vindas tanto do reino das pessoas quanto aquelas vindas do reino das ideias, dos saberes. Esses dois reinos são indissociáveis e concordamos com a proposta de que são componentes de sistema mais amplo. Entretanto, nosso esforço não é o de apenas produzir uma taxonomia da sala de aula. Ao invés disso, queremos explorar o reino dos saberes e o reino das pessoas a partir de suas redes de relações e ainda queremos explorar relações entre esses reinos. É por isso que uma pesquisa como a que apresentamos aqui precisa ir ao chão de sala de aula, e precisa se dar no decorrer de seus acontecimentos típicos e de suas configurações típicas.

E estamos partindo de um aparato representacional que é sedimentado em diferentes campos de investigação de sistemas ou cenários que sejam complexos. Tal aparato nos permitirá representar emergências da sala de aula e é por eles que a interpretaremos. Mas aceitamos que por mais elaborado que seja um aparato de representação de um cenário, ele nunca será equivalente ao cenário representado. 
Uma ilustração dessa limitação pode ser feita se pensarmos numa maquete de uma casa. A única maquete que poderia ser precisamente equivalente à casa seria uma outra casa idêntica. Do mesmo tamanho. Mas neste caso, em quê a maquete ajudaria a entender a casa? As representações de um objeto são necessariamente limitadas em relação ao próprio objeto. Mas é certo que são úteis para ver aspectos do objeto que escapariam a nosso olhar se olhássemos para o original. São inegáveis o valor e a utilidade de uma maquete para o entendimento de uma grande obra de arquitetura, mesmo que ela já tenha sido construída.

A ilustração da Figura 3 mostra que as redes que utilizaremos como nossos aparatos de representação da sala de aula são, sabida e intencionalmente, limitadas em relação à sala de aula em si. Mas são também uma forma de promover percepções sobre aspectos sutis da sala de aula. Pelo uso das representações e particularmente pelo acoplamento de diferentes reinos da sala de aula, como nos propomos a fazer nesta tese, têm-se a oportunidade de interpretação de suas estruturações não manifestas. Assim, nos aproximamos do entendimento de alguns aspectos da complexidade das relações estabelecidas em sala de aula.

Ao considerarmos a sala de aula olhando-a pela díade $\mathrm{S} \leftrightarrow \mathrm{E}$, entendemos ser necessário partirmos de dois vieses de investigação. E cada um desses dois vieses possuem suas respectivas abordagens empíricas. Enquanto num deles, buscaremos entender os elementos de consenso e os de dissenso que emergem como representações compartilhadas, no processo de ensino/aprendizagem de Ciências, mais precisamente os da Física, neste trabalho. No outro, buscaremos tornar visíveis as afiliações interpessoais que emergem daquele micro-mundo social escolar, conforme esquematizado na Figura 3.

As duas formas de estruturação, uma representacional e outra social, mostradas na Figura 3 e que investigaremos vêm de constituições próprias, embora se relacionem e se influenciem. Isso impõe a necessidade de irmos além da escolha de uma base teóricometodológica bem solidificada para investigarmos um fenômeno particular da sala de aula ou de costurar adequadamente uma novidade metodológica a uma base teórica sólida. 
Figura 3 - Aresta do Sistema Didático e seus polos tomados como objeto de interesse

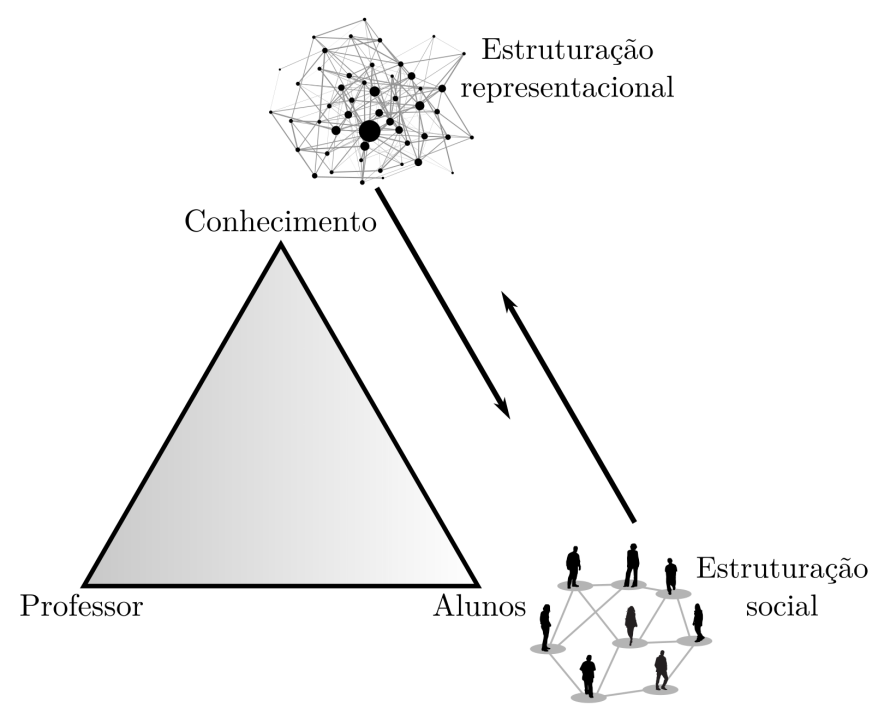

Fonte: elaboração nossa.

O que buscamos é a conciliação de duas formas de olhar a complexidade da sala de aula. E isso demanda aportes teóricos complementares, que deem suporte ao sentido que buscaremos construir. No entanto, como diferentes tradições de programas de pesquisa acabam formando polarizações acadêmicas, há uma suposta impossibilidade de se desenvolver uma pesquisa que concilie frentes distintas de pensamento. No sentido de superar essa polarização limitante, nos inspiramos em propostas que utilizam visões multifacetadas na pesquisa em Educação em Ciências.

Um dos autores que defende tal visão é Kenneth Tobin, que explicita a necessidade de se munir de diferentes aportes, para que se iluminem diferentes aspectos do que ele classifica como paisagens. Para Tobin "[...] à medida que teorias iluminam paisagens de determinadas formas, elas simultaneamente obscurecem ou falham em discernir outras potenciais questões salientes" (TOBIN, 2008, p. 227, tradução nossa).

Tobin defende convergência de mais de uma lógica de pensamento, na pesquisa naturalizada em sala de aula, como forma de se enxergar aspectos que sempre ficarão omissos em um recorte teórico/metodológico. Múltiplas perspectivas teóricas na pesquisa em educação científica, permitem a ampliação da visão do pesquisador que, por meio de um processo de bricolagem, constrói sentidos para os acontecimentos da sala de aula. 
Um análogo à tônica central da proposta de Tobin pode ser reconhecido na emblemática frase do pintor René Magritte, de que "[...] aquilo que é visível, sempre omite algo visível" (ALLEN, 1999, p. 95, tradução nossa). O surrealismo de Magritte e seu questionamento de interpretações a partir de pontos de vista nos inspira. Se tudo que vemos, omite alguma coisa, quando pensamos na complexidade da sala de aula vemos um análogo: qualquer viés de observação omitirá tudo que ele não é.

Assim, a produção de sentidos pode ser beneficiada pela composição de diferentes formas de observação do nosso objeto (de pesquisa, no presente caso). Se o fato de escolhermos olhar implica alguma omissão, pontos de vista rigidamente definidos e inflexíveis utilizados para fazer sentido do mundo sempre estarão negando todas as outras formas de ver o mundo; sempre estarão negando outros mundos.

Esse fato retoma nossa declaração da limitação inerente a qualquer recorte de observação. Mas também nos impulsiona buscar formas de se acoplar diferentes lógicas, métodos e aportes, tais que nos permitam iluminar mais aspectos da paisagem, como diria Tobin, e explorar novas relações entre eles. E pela adoção de uma postura desse tipo, é possível diminuir o vão de omissões existente em cada forma de olhar um problema de pesquisa.

Mas um tributo que se paga ao trabalhar no acoplamento de lógicas complementares, como nas perspectivas multi-teóricas e multi-lógicas, é que a uma pesquisa que se empenhe na busca por convergências de olhares, coloca o pesquisador a operar em um terreno menos firme. Especialmente por lidar com vieses, às vezes, conflitantes, como no caso da análise de conhecimento e a análise situacional. É o que ressaltam (BROWN et al., 2015) sobre as aproximações entre estudos focados em análise do conhecimento e estudos focados em análises de interações:

Dada a história contenciosa dos paradigmas cognitivos e situacionais, há que se entender que pesquisadores das análises do conhecimento e os das análises das interações possam interpretar diferenças salientes em focos seletivos como emblemas de barreiras profundas e supostamente intransponíveis. Nós, no entanto, discordamos. Nossa crença é de que pesquisadores trabalhando em ambas perspectivas provavelmente se beneficiarão de estudos sobre como o outro lado opera. 
Mas a recompensa que se tira do esforço por uma articulação entre as lógicas das relações interpessoais e representacionais é que podemos proceder uma investigação da sala de aula de forma integrativa. E isso nos permite olhar aspectos novos. Mas não sem novos desafios. Um desses desafios é a complexidade inerente. Algo que Brown e colaboradores também ressaltam, quando declaram que:

Há todo tipo de razão para acreditarmos que essa agenda será complexa, que a soma das análises de conhecimentos com as análises de interações é maior do que suas partes. De fato, complexidade é evidente em todo lugar. A análise de conhecimentos têm estabelecido que sistemas de conhecimentos são complexos e análise de interações têm estabelecido que sistemas de interação são complexos; considerar relações entre esses dois sistemas complexos adicionará outra camada de complexidade.

(BROWN et al., 2015, p. 26, tradução nossa)

Brown e colaboradores estão se referindo à proposta de uma agenda sintética, integradora, para a pesquisa em ensino/aprendizagem de Ciências. A nós também as complexidades inerentes aos acontecimentos da sala de aula de Ciências parecem evidentes. São justamente essas complexidades inerentes que indicam a necessidade e a vantagem de se acoplar lógicas de interpretação que venham de tradições diferentes.

Com essa abordagem, intentamos lidar com essa característica que não se manifesta explicitamente, mas que não deixa de permear o cenário real da sala de aula: a complexidade. No entanto, não havendo uma forma objetiva de observação do que se chama complexo, o que de melhor pode ser feito é buscar nas redes uma forma de representação do sistema sala de aula, promovendo pelas redes uma integração de diferentes áreas do saber, e interpretando nas redes as situações, os cenários, as estruturas ou os sistemas que emergem da sala de aula.

\subsection{Redes como possibilidades para a sala de aula}

A estratégia desta tese é, em linhas gerais, a de se pensar a sala de aula como sendo o local de estruturações em diferentes níveis. Com isso, podemos investigar, no complexo dessas estruturas, a emergência de diferentes padronizações. Isso tanto no emaranhado de ideias que circulam no grupo e que emergem como representações produzidas pelos alunos, 
quanto no emaranhado de afiliações interpessoais que esses mesmos alunos estruturam por suas convivências em sala de aula.

Com essa estratégia almejamos desempacotar alguns dos processos que constantemente ocorrem em sala de aula, tornando assim as relações ali formadas um tanto menos herméticas. Almejamos também construir, a partir das emergências explícitas, alguma capacidade explicativa para esses processos da sala de aula, torando-os assim um tanto menos estranhos.

Nesse sentido, enquanto o pano de fundo deste trabalho é a complexidade, o conduíte que ligará as diferentes perspectivas que utilizaremos é a Ciência das Redes, que abordaremos à frente. As redes servirão para organizar nosso pensamento sobre a complexidade da sala de aula. Pensarmos nas redes da sala de aula é nos posicionarmos em oposição a uma análise linearizada ou hierarquizada daquele ambiente social e representacional.

As redes, nesta tese, também são método. Servirão para construção de representações e metarrepresentações explícitas de diferentes aspectos da sala de aula. Para isso, buscaremos apoio em alguns fundamentos da Teoria dos Grafos. Em diferentes áreas de investigação, grafos tornam possível a exploração explícita de estruturações formadas por elementos e processos que são implícitos a sistemas e cenários dotados de complexidade.

As potencialidades do uso das redes como forma de representação e análise de sistemas complexos fazem com que essa abordagem seja pervasiva e promissora. Mas essa mesma abordagem traz consigo o risco de invocação de determinismos estruturais acerca do sistema representado. Nosso julgamento é o de rejeição a tais determinismos. Em um pensamento que inclua o viés de complexidade, há uma tensão natural entre o emergentismo e o resultismo, o que pressiona as noções de causalidades em sistemas complexos, algo que buscaremos elaborar à frente. Mas essa tensão nos ajuda a manter o risco de recorrer aos determinismos estruturais sempre à vista.

Mas esse risco não deve ofuscar o fato de que há um potencial informativo na observação de estruturas complexas como redes. Nos diferentes sistemas em que entidades interagem ou se relacionam, emaranhando relações complexas, redes assumem o papel 
tanto de artefatos do pensamento quanto de ferramentas metodológicas, para permitir a construção de racionalidades. Permitem análises em nível de sistema. Com as redes é possível tomar traços objetivos, capturados dos elementos e fatos constituintes do sistema, para que se possam avaliar tanto a estrutura quanto a função das relações complexas emergentes.

Outro risco de determinismo é o uso as redes da sala de aula no sentido de perfilamento de indivíduos. Esse é um risco que opera também no âmbito da ética. À época da produção do texto deste trabalho, vivemos tempos nos quais o perfilamento de humanos, no estilo data driven ${ }^{2}$, se ramifica. Nesse cenário, as análises estruturais de relações interpessoais com grandes massas de dados, no ciber mundo da internet, direciona a propaganda daquilo que cidadãos consomem (CHEN; HSIEH, 2012), sugere soluções para personalização de cuidados de saúde (VICECONTI; HUNTER; HOSE, 2015) ou até determina trajetórias individualizadas de aprendizagem (CHILDRESS; BENSON, 2014).

Nosso problema de pesquisa não é movido por um ímpeto tecnocrata de utilizarmos a análise de redes em sala de aula para perfilarmos alunos, negando suas identidades e subjetividades. Nem tampouco e a missão final desta tese não é a de culminar num modelo de ensino que mimique ou adapte os moldes dos grandes aplicativos digitais, a partir da utilização das redes.

Em uma outra rota, esta tese é movida pela percepção de que, ao ampliarmos nosso olhar sobre o chão da sala de aula e reconhecermos sua complexidade poderemos entendê-la mais intimamente. E nos valemos do pensamento em redes como elemento que permitirá tal ampliação. Recorremos às redes para que nos ajudem a entender como um grupo, reunido no espaço e no tempo a partir de demandas institucionais da escola, se interconecta para produzir e compartilhar representações simbólicas acerca de temas que são sensíveis às suas realidades escolares e de vida.

Isso não significa que buscamos um perfilamento de indivíduos. Vemos um contrassenso no perfilamentos de indivíduos a partir de sua categorização com grandes redes de

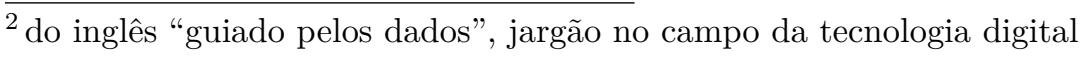


relações, como as grandes massas de dados da internet. Tentar determinar um perfil para um indivíduo, usando as redes que emergem em sala de aula, implica em uma redução que quase robotiza tanto as redes quanto o coletivo: as redes seriam transformadas em ferramenta de categorização e o coletivo não teria outra função, que não a de ser o insumo gerador dessas categoria.

Um uso das redes como categorizadoras ou como perfiladoras, servindo para dizer apenas se um indivíduo se encaixa ou não num padrão, apaga a relação entre indivíduo e grupo. Esse processo resulta em uma desconexão porque ignora o papel do indivíduo como também produtor, componente e transformador das estruturas, das redes que gerariam tais categorias.

Essa crítica a perfilamento é posta para que não neguemos a existência das individualidades que formam a rede. Os egos (indivíduos ou "eus") são elementos das redes da sala de aula e, como tal, nosso interesse se volta também a eles. Mas os olharemos sempre na busca pelo entendimento de sua relação com seus alteri (relativo ao outro) e com todo do grupo.

As relações ego $\leftrightarrow$ alteri e também as relações ego $\leftrightarrow$ grupo, formadas em sala de aula, são internas ao polo $E$ do sistema didático. São elas que dão forma às redes de pessoas (sociais) na sala de aula. Mais especificamente, elas são pontes interpessoais, são relações intersubjetivas como afinidades, atrações, associações, afiliações ou outro que o valha.

Mas não nos interessa somente encontrar formas de tornar explícitas a complexidade das redes de pessoas da sala de aula. Queremos também discutir sobre como as relações interpessoais nessas pontes inter-alunos operam no jogo da formação de consensos. Uma vez que os consensos são representados socialmente e circulam entre os participantes da sala de aula, a relação entre essas pessoas não se dissocia da formação desses consensos. É especificamente aí que o nível extra de complexidade é adicionado, conforme sugerido por Brown e colaboradores. É aí que se tem a díade rede de pessoas e rede de ideias. É nessa complexidade extra que se forma a aresta $E \leftrightarrow S$ do sistema didático de Chevallard. 
Ao tratarmos do processo didático considerando as redes como forma de aproximação entre o reino das ideias - o cognitivo - e do reino das pessoas - o social -, estamos lidando com um grupo que tem o tamanho da sala de aula. Logo, não partimos da lógica do big data (grande massa de dados). Uma sala de aula tipicamente é um grupo de poucas dezenas de pessoas. Assim, comparado às análises de redes de bilhões (literalmente) de pessoas no ciber mundo, nosso estudo é uma análise procedida em um universo numérico bem mais modesto, com dezenas de alunos, em sala de aula. Nossos sujeitos de pesquisa são um grupo que configurariam o que se poderia chamar de "pequenos dados". E, por tudo que argumentaremos neste trabalho, defendemos o uso e o potencial informativo das redes nesses universos de "pequenos dados".

Nosso olhar está na fronteira grupo/indivíduo e nas suas relações com a produção de representações compartilhadas. Nessa fronteira, os diferentes usos das redes tanto como organizadoras do nosso pensamento sobre a sala de aula, quanto como metáfora para a complexidade e ainda como aparato metodológico, indicam o tom deste trabalho. Não temos uma pesquisa cujas asserções sejam puramente orientadas pelos dados, como nos perfilamentos de indivíduos. Na outra mão, o componente empírico desta tese, presente em um estudo de caso que apresentaremos à frente, também não nos deixa dizer que esta seja uma pesquisa orientada por uma teoria (única), o que retorna a nossa inclinação à orientação multi-lógica.

Tendo sido essa nossa proposta definida como mais adequada para lidarmos com a sala de aula multifacetada, intentamos com ela conseguir olhar mais de perto algumas faces das complexidades do locus de ensino. Mas para que a complexidade seja incluída na conta, nos parece difícil imaginar o uso de uma base teórico/metodológica única. Por isso, buscamos olhar para onde os diferentes programas de pesquisa da educação se aproximam, ao invés de olhar para os polos nos quais escolhem focar para que se afastem.

Quando nos posicionamos dessa forma, ao pensarmos a pesquisa educacional, estamos trabalhando como bricoleurs, como nas palavras de Rogers (2012). No processo de bricolagem, buscaremos acoplar visões que sejam complementares para que possamos entender as redes da sala de aula nos dois vértices do sistema didático que apresentamos. 
Justamente por virem de matrizes de pensamento diferentes é que as redes de pessoas e as redes de ideias nos permitem proceder análises que bricolam diferentes tipos de evidências, iluminando diferentes aspectos da paisagem.

Também alinhado à noção de bricolagem proposta por de Rogers, Tobin (2010) alerta que para procedermos o acoplamento de múltiplas perspectivas, há que se escolher terrenos bem sedimentados. Nas palavras de Tobin, uma proposta multi-lógica e multiteórica precisa combinar "[...] quadros teóricos cuidadosamente pensados e completamente desenvolvidos" (TOBIN, 2010, p. 407, tradução nossa). Por isso, neste trabalho os dois campos de investigação utilizados são, cada um deles, historicamente bem sedimentados tais que tanto as redes de pessoas quanto as redes de ideias encontram aportes metodológicos e teóricos suficientemente estáveis.

O caminho das redes adere à proposta de bricolagem teórica e metodológica. Bruun (2016) destaca as redes como vantajosas na pesquisa educacional, tanto utilizada para investigação em âmbito social, quanto para investigação em âmbito cognitivo. Mas, mais que isso, as redes ainda são vantajosas como forma de se sobrepor esses diferentes âmbitos de análise, provendo a modelagem e a observação de aspectos sutis. Qualquer que seja o domínio de observação, as redes operam como forma de desmontar e remontar o cenário para que, então, se possam produzir entendimentos:

Numa perspectiva metodológica, trabalhar com as redes impõe uma série de condições de contorno. Primeiro, um fenômeno particular, um sistema ou objeto de investigação é projetado em uma rede. Qualquer projeção é uma redução que dá ênfase à estrutura relacional inerente ao fenômeno, sistema ou objeto. A projeção separa o fenômeno, sistema ou objeto, em partes e elas re-emergem como uma rede. Depois, as redes têm uma história; elas foram criadas de alguma forma e elas podem mudar quando influenciadas por algum evento. As redes que nós investigamos são produtos dessa história, o que significa que podemos esperar redes que sejam bem diferentes, mesmo quando elas deveriam descrever o mesmo fenômeno. Por último, as redes são heterogêneas, isto é, cada nó é uma entidade única. Única por causa da forma como ele é conectado a outros nós da rede. Uma metodologia das redes leva em consideração essa singularidade e isso pode promover uma análise extremamente detalhada do fenômeno, sistema ou objeto.

(BRUUN, 2016, p. 11, tradução nossa)

Então, nesse trabalho encontramos apoio, de um lado, para o uso das redes em 
suas formas explícitas, os grafos de palavras, para abordarmos a complexidade inerente às representações produzidas e compartilhadas pelos estudantes. A abordagem de redes, nesse sentido, já fora utilizada para análise da evolução estrutural tanto das relações semânticas no aprendizado de acústica (RODRIGUES; CAMILETTI, 2018), quanto dos discursos de um grupo de alunos, sobre o aquecimento global (WATANABE et al., 2017), mostrando em ambos os casos, a ocorrência de uma complexificação de associação léxica, no processo de aprendizagem. Nesse polo, das ideias compartilhadas, a Teoria das Representações Sociais (TRS), proposta inicialmente por Moscovici (1978) e desdobrada em uma vertente que se debruça em explicitar e analisar estruturas semânticas complexas, nos ajuda a iluminar o reino das ideias em circulação entre os alunos. Com esse aporte, podemos investigar os produtos e os mecanismos de produção de consensos, considerando a linguagem como referente de noções compartilhadas pelos alunos.

No outro polo, recorreremos à análise explícita das relações interpessoais, algo que nasce com a sociometria, no trabalho de Moreno (1934), mas que se desenvolveu para o que atualmente se reconhece como Análise de Redes Sociais (ARS). Neste outro polo, os grafos atuam como representações imagéticas que tornam explícitas as relações entre alunos. A abordagem de redes para investigação das relações entre alunos já foram utilizadas para investigação de fóruns de discussão (PUCINELLI; GIORDAN, 2017) e colaborações nas aulas (SENGUPTA-IRVING, 2014). Então, os grafos referentes à ARS nos ajudam a iluminar no reino de pessoas (de alunos), na sala de aula. Quais são, como estão e com quem se afiliam os alunos, são perguntas necessárias ao entendimento da trama interpessoal produzida tacitamente por aqueles alunos e emergindo a partir de diferentes demandas.

Ao utilizarmos as redes, tanto no reino das pessoas, quanto no reino das ideias, procederemos análises que incluirão algum tipo de processamento matemático dos registros de pesquisa. Avaliações estruturais das redes, como a centralidade de um elemento na rede ou o delineamento de um subgrupo da rede, são feitas por algum processo numérico. Mas, embora tais processos estarão nos entremeios metodológicos das técnicas de análise, esta tese não produzirá asserções determinísticas de ordem quantitativa. 
Os referentes numéricos da parte empírica desta tese não funcionam como pontos de corte. Não estamos tratando de um teste de hipótese. Nosso pensamento sobre a complexidade, pelas redes da sala de aula, nos leva a uma abordagem de pesquisa que não se caracteriza como experimental ou quasi-experimental. Nossas redes, embora precedam de alguma matemática, não estão a serviço de gerar categorias rigidamente definidas.

Quando a sala de aula é analisada por suas redes, a matemática dos grafos não é auto-evidente. Nem tampouco as estruturas possuem significado intrínseco. As redes, aqui, se referem sim a estruturas ou, mais adequadamente, às estruturações da sala de aula. E isso nos ajuda a interpretar o cenário; a pensar uma pedagogia que não se dê alheia a essas estruturações. E isso diverge dos estudos que se valem de distribuições amostrais e avaliações de tendências centrais.

Por isso, recorremos às redes da sala de aula como artifícios de produção de estruturas emergentes e de interpretação dessas estruturas. Estruturas que ligadas às produções coletivas, às representações simbólicas, às afiliações e aos agrupamentos microssociais.

Investimos nas redes por seu potencial de apresentar novidades. Por seu potencial de se referir a diferentes reinos. Por sua possibilidade de aproximação de diferentes vieses teóricos. Por sua natureza de acomodação de aspectos múltiplos. Por se referir e até se fundir à noção de complexidade. E, diante disso, declaramos os objetivos deste trabalho.

\subsection{Objetivos}

O objetivo amplo desta tese é explorar aspectos da complexidade da sala de aula a partir do uso das redes complexas, emergentes tanto do âmbito interpessoal quanto do âmbito representacional, visando elucidar seus processos mútuos de estruturação.

De modo específico, neste trabalho almejamos:

- Elaborar uma discussão sobre a complexidade da sala de aula, pelo viés das redes;

- Propor os grafos como forma de observação explícita das complexidades da sala de aula; 
- Levantar e analisar as Representações Sociais emergentes de um grupo de alunos do Ensino Médio;

- Levantar e analisar diferentes Redes Sociais, a partir de variados critérios sociométri$\cos$;

- Produzir uma abordagem de utilização integrada das redes para investigação de estruturas tanto de ideias compartilhadas quanto de afiliações interpessoais dos alunos;

- Explorar relações entre dríades humanas na Rede Social complexa dos alunos e os consensos nas Representações Sociais produzidas por eles. 


\section{Complexidade e redes}

Complexidade comę̧a quando a causalidade cai.

Nigel Goldenfeld

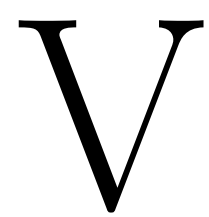

VEMOs num mundo repleto de redes. Vivemos numa rede chamada mundo. Cada ser é elemento de uma rede. Cada ser é composto de muitas redes. Estudamos em uma rede de escolas. Cada escola é uma rede. Cada aluno é sobreposição de muitas redes. Cada aluno é elemento componente de uma grande rede. São incontáveis as formas de abordagem da complexidade do "real" que recorrem às redes. Essas abordagens fazem as redes variarem entre metáfora, teoria, imagem ou método.

Tomemos, de início, um fato ocorrido à época da redação deste trabalho: o mês de novembro do ano de 2019 foi o mês no qual uma das principais revistas científicas do mundo, a Nature, comemorou seu sesquicentenário. A capa de sua edição especial de aniversário estampa uma grande e complexa imagem ${ }^{1}$, combinando uma enormidade de círculos coloridos e linhas que os conectam. Formam uma grande trama de co-citações de autores em trabalhos acadêmicos e é utilizada para a construção de um entendimento sobre o caráter multidisciplinar da revista em seus 150 anos de publicações.

O trabalho que dá origem à imagem de capa da Nature é uma extensiva metapesquisa feita por Gates et al. (2019), que mineram informações tomando por base um corpus de mais de 19 milhões de artigos. Desses, mais de 700 milhões de relações de co-citações são identificadas. A partir de uma filtragem, chegam a mais de 80.000 artigos publicados pela emblemática revista britânica e então produzem uma rede na qual relações são estabelecidas quando autores de um trabalho se remetem a autores de outro trabalho. Uma rede de relações entre pesquisas.

Essa rede codifica por cores as áreas do saber das publicações mapeadas e indicam

\footnotetext{
${ }^{1}$ sugere-se uma apreciação da versão em vídeo, oficialmente produzida para explorar o leque informativo da rede de co-citações, que se encontra disponível em <https://youtu.be/GW4s58u8PZo>
} 
aspectos peculiares. Um deles é a tendência que alguns campos do saber têm de aglomerarem trabalhos da mesma área (i.e. pesquisas sobre estrelas semelhantes ao Sol). Outro é a tendência de algumas áreas se remeterem mais constantemente a trabalhos de outras disciplinas. (i.e. pesquisas com buraco da camada de Ozônio que aglomeram Química, Ciências Sociais e Ciências da Terra). No mesmo volume da Nature, em seu breve texto de apresentação da capa da edição, Baker (2019) não se furta de cravar que a "ciência é uma rede", referindo-se ao trabalho de Gates et al. (2019).

Sem considerar a possibilidade dessa menção, em si, acabar de estabelecer uma nova relação de co-citação nessa mesma rede, a pergunta que se faz é: que poder tamanho é esse, o das redes, tal que cumprem a função de serem um jeito de falar das coisas, das coisas complexas? Deixamos claro que o empenho no presente trabalho não é o de pressionar a borda do conhecimento no campo da ciência das redes, nem tampouco no da ciência da complexidade. Mas esse poder informativo e pervasivo que o pensamento das redes confere, aliado ao reconhecimento de que a sala de aula é uma aglomeração humana complexa, é o que nos impulsiona, desde a gênese, esta tese.

Do pensamento da complexidade, tomamos algumas noções que ajudam interpretar a sala de aula de maneira não determinística. Do pensamento das redes, tomamos nosso ponto de partida para reflexão, exploração e apresentação das estruturas que emergem da sala de aula. Com isso, nos opomos a noções hierarquizadoras ou categorizadoras da sala de aula. É por essa oposição que poderemos enxergar, no complexo das redes da sala de aula, nuances da realidade didática que ali ganha forma.

\subsection{Ares do complexo}

Na contemporaneidade do pensamento científico, o interesse em se aproximar de alguma realidade, qualquer que seja, passa por incluir sua complexidade inerente. Mas na inclusão da complexidade, faz-se necessário um pensamento que considere mais que a análise voltada aos objetos que compõem uma realidade. Há a necessidade de ir além do pensamento em termos de elementos que constituem um cenário. 
A complexidade de uma realidade se apresenta, claro, em seus elementos. Mas não apenas. Pois uma realidade observada deve ser pensada também em termos das relações existentes entre seus componentes. O aspecto relacional é fator que aponta a complexidade. É dele que emanam recombinações, retroalimentações, padrões de organização e emergências. Fenômenos que, para citar alguns, são típicos do pensamento da complexidade.

No sentido de provocar um elucidário, Semegen (1994), em sua vanguarda musical, parte de uma abordagem artística para propor diferentes formas de se falar sobre a complexidade. Vocábulos aos quais recorremos quando esbarramos em nossa incapacidade de descrever ou definir complexidades. A artista propõe que se pondere a complexidade sendo versus/e/como:

clareza [...] simplicidade [...] utilidade [...] talento artístico [...] imaginação [...] informação [...] nuance [...] estética [...] percep̧ção [...] diversidade [...] totalidade [...] análise [...] humildade [...] ideologia [...] ilusão [...] organização [...] novidade [...] embelezamento [...] controvérsia [...] beleza [...] humor [...] plenitude [...] originalidade [...] transformação [...] variação [...] ambiguidade [...] consciência $[. .$.$] dificuldade [...] desorganização [...] conformidade [...] tendência$ $[. .$.$] desvio [...] emaranhamento [...] absurdo [...] duplicidade [...]$ obsessão [...] ilusão [...] turgidez [...] hipérbole [...] tortuosidade [...] circunscrição [...] auto-importância [...] pseudociência [...] caos [...] academia [...] decepção [...] pomposidade [...] temor [...] enganação $[.$.$] intimidação [...] hierarquia[...] carreirismo [...] burocracia [...]$ os desinformados [...] poder [...] visão de túnel [...] desinformação $[.$.$] obscurantismo [...] desorientação [...] verbosidade [...] egoísmo$ $[\ldots]$ confusão $[. .$.$] ofuscação$

(SEMEGEN, 1994, p. 220-222, tradução nossa)

Longe de ser exaustivo, o glossário de Semegen escancara o problema e a sorte daqueles que se dispõem a considerar a complexidade. Para isso, a autora, (loc. cit.), utiliza três formas típicas de caracterização de um objeto. Primeiro pela oposição (versus), propõe que a complexidade seja revelada por aquilo que ela não é, por aquilo que a ela se contrapõe: a complexidade definida por suas antíteses. Depois pela noção de adição $(e)$, a complexidade pode ser caracterizada por aquilo a que se adere, por sua proximidade a uma outra entidade reconhecível, à qual possa se assemelhar. Outro aspecto de se pensar a complexidade " $e$ " é a busca por defini-la naquilo que a ela seja complementar. Por último, 
pode-se pensar em complexidade pelas diferentes formas que ela venha a tomar (o como). A complexidade "como" seria então caracterizada em algum outro aspecto pelo qual se apresenta. Pelo caráter no qual é reconhecida. Por sinônimos que a ela se possam atribuir.

Ao colocar a complexidade versus/e/como, vê-se que Semegen além de expor o potencial de contradição encarado por aqueles que empenham tentativas de defini-la, ainda metautiliza um preceito: não se trata da complexidade ou versus, ou e, ou como, mas sim versus/e/como ao mesmo tempo. A complexidade se opõe à informação, complementa a informação e se apresenta como informação. A complexidade se opõe ao embelezamento, complementa o embelezamento e se apresenta como embelezamento. A provocação criativa de Semegen emaranha o sentido daquilo que é, de fato, complexo. Isso nos tira a inocência de imaginar que seríamos capazes de definir a complexidade, de reduzi-la ao inteligível, ao linear.

Mesmo que o termo "complexo" ${ }^{2}$ possa ser fugidio e que tentativas de defini-lo sejam labirintos, é possível e necessário que levantemos considerações sobre a complexidade, sejam elas versus, e ou como, tais que a ela nos refiramos como uma noção, como uma utopia. Assim, o léxico referente à complexidade se torna um caminho para cercar suas características e para esclarecer seu papel na construção de uma racionalidade sobre uma realidade de interesse.

Ao se levantar um glossário sobre a complexidade, é certo que não se busca responder a perguntas fulcrais como: seria a complexidade o elemento unificador de todos os contextos? ou o que "há" na complexidade? ou ainda é possível medir a complexidade?. Tais questões estão, para a ciência, na vanguarda do conhecimento humano e, para a filosofia, na borda da racionalidade. Em relação à primeira, podemos exemplificar casos de grupos especializados que reúnem matemáticos, estatísticos e outros profissionais da ciência ${ }^{3}$ que se dedicam a modelar realidades complexas e a avançar numa ciência da complexidade. Em relação à segunda, a discussão se volta à metafísica e à ontologia, o que

\footnotetext{
2 etimologicamente, o termo complexo tem origem no latim complectere, no sentido de abarcar, compreender e também do latim complexus no sentido de entrançado

${ }^{3}$ como o Santa Fe Institute <https://www.santafe.edu/>
} 
leva ao pensamento do que viria a compor a complexidade.

\subsubsection{Composição e complexidade}

Chamemos a atenção para o termo composição quando pensado para a complexidade. A ideia de se "compor uma complexidade", ou seja, de se pensar a complexidade como composta por partes e, possivelmente então, descrita a partir dessas partes carrega a noção de que o complexo poderia ser caracterizado por uma mereologia simplista do sistema a que se refere: a soma das partes seria o todo. Argumentaremos que isso não se verifica, quando pensamos em estruturações complexas.

Mereologia é o nome dado à teoria das partes: das relações entre as partes e o todo e das relações entre partes, dentro de um todo (VARZI, 2003). Com raízes na filosofia pré-socrática, a mereologia está presente em escritos de períodos posteriores, como na metafísica aristotélica e desempenhando papel importante nos escritos dos ontologistas e filósofos escolásticos medievais. O autor difere a mereologia da teoria de conjuntos, já que ambas tratam de entidades e seus componentes. Na teoria de conjuntos, há um compromisso com a existência de um abstracta, uma vez que o conjunto não é uma entidade de mesma natureza ontológica que seus componentes, mas tem um status abstrato. $\mathrm{Na}$ mereologia, o todo pode ser tão concreto quanto as partes. Por outro lado, mereologia também não carregaria compromisso com o concreto, uma vez que o todo pode ser tão abstrato quanto as partes. Então, a mereologia, enquanto teoria formal, é uma tentativa de proposição dos princípios gerais das relações entre entidade e seus constituintes, qualquer que seja a natureza da entidade.

Das diferentes formas de se falar da complexidade a partir de metáforas, o uso da noção mereológica se apresenta como uma delas. Ao pensarmos em complexidades contidas em complexidades ou complexidades compostas de complexidades, estamos invocando uma forma metafórica tipo-contenção. O uso de metáfora para além de sua função como figura de linguagem, mas tomado como organizador das noções, é um artifício para a lida com demandas da realidade que é legítimo e bem documentado (LAKOFF; JOHNSON, 2008). Já recorremos a esse artifício anteriormente neste texto. Recorreremos a ele em 
outros momentos. Não é que as metáforas estejam desautorizadas, quando o objeto de pensamento é a complexidade. Na verdade, ao contrário, elas são fundamentais. No entanto, a metáfora da contenção (ou do confinamento) quando aplicada à complexidade, subscreve os princípios mereológicos e, inevitavelmente, trata da complexidade a partir da conjunção de suas partes constituintes. Esse uso é problemático porque, primeiro, assume que, no caminho oposto, a complexidade é passível de decomposição em partes; depois porque ao se valer de uma noção de composição atomística, inconsistências relacionadas à causalidade são produzidas.

Relativo ao primeiro problema acima, a oposição entre complexidade e plenitude (ou completude) é compartilhada por Morin (2015), que afasta, pelo que são, embora aproxime pelo que aspiram ser, a complexidade e a completude:

Num certo sentido, eu diria que a aspiração à complexidade traz em si a aspiração da completude, já que se sabe que tudo é solidário e que tudo é multidimensional. Mas num outro sentido, a consciência da complexidade nos faz compreender que jamais poderemos ter um saber total

(MORIN, 2015, p. 69)

Nota-se que o autor acima rejeita os dois extremos. Rejeita a hiper-simplificação da intenção de se compreender a realidade, a partir de uma visão unidimensional, pois uma vez conscientes da multidimensionalidade, as visões especializadas, unidimensionais, seriam sempre pobres. Mas rejeita também a hiper-valorização da ideia de que pela complexidade alcançaríamos a completude do saber.

A crítica de Morin ao fato de que as categorias criadas por universidades são muitas vezes tomadas como realidades simplificadas, apontam para um processo de unificação das ciências. Economia e psicologia são disciplinas cujas fronteiras estão bem definidas e que tem seus próprios estatutos epistemológicos. Mas qualquer análise da realidade econômica encerrada em si ou qualquer análise da realidade psicológica encerrada em si é processo reducionista. Não se trata de um reducionismo ingênuo. O reducionismo disciplinar, causado pelas organizações das diferentes matrizes de saber, promoveu avanço em todos os campos do conhecimento que estabeleceram seus programas de pesquisa. 
Tampouco se afirma aqui que uma análise estritamente disciplinar de um objeto de observação não seja uma análise cientificamente válida. Mas há que se reconhecer, caso se tenha compromisso com a inclusão da complexidade, que uma análise estritamente disciplinar nas duas áreas, terminariam por ignorar fatos como $(i)$ a realidade econômica está intimamente ligada às necessidades e aos desejos humanos e (ii) que como pano de fundo do dinheiro, estão as paixões e a psicologia humana.

Isso leva à conclusão de que sem a consideração de elementos que são de fundo, mas que sempre influentes, estaríamos reduzindo nosso campo de análise a um pensamento simplificador. Mas, em oposição à noção mereológica, na hipótese ilustrada, a consideração dos fatores econômicos na psiquê e de fatores psicológicos no sistema econômico não se trataria de um pensamento composto por esta mais aquela disciplina. Seria sim um pensamento com noções novas, com questões emergentes que sequer existem de maneira prospectiva antes que um estudo pretenso à unificação se desenvolva. Um pensamento que se representa por algo novo e maior que a união dessas duas disciplinas constituintes.

A complexidade é um fato quando se buscam aproximações de alguma realidade ou entre realidades diferentes. Embora do ponto de vista filosófico o debate sobre a busca por unificação das ciências e por pontes entre teorias seja tarefa da metafísica (LADYMAN et al., 2006), esse debate parece se dar em oposição à mereologia e inevitavelmente aponta para questões da complexidade. De acordo com Ladyman e colaboradores (ibid.), mesmo tomando-se versões mais modernas da mereologia, é presente um comprometimento com a metáfora da contenção de Lakoff e Johnson.

O uso da metáfora na qual um sistema seria definido por aquilo que nele estaria contido se alinharia à noção aristotélica de uma "causação eficiente". Nesse tipo de pensamento o processo causal "fluiria" de dentro para fora do sistema. A composição do mundo, nessa visão, estaria, em última instância, definida pelos elementos da menor granulação que formaria o mundo. Dali, dessa escala limite, os constituintes do sistema deteriam o poder causal que, de alguma forma, sustentariam e determinariam todo o edifício de relações causais do mundo. Para Ladyman e colaboradores, a incongruência desse modelo é que ele terminaria por concentrar o poder causal do todo nas unidades 
elementares que o constituem. Então, isso levaria o trabalho da ciência a ser o de olhar apenas para um mundo "feito de".

Uma vez apoiada na metáfora da contenção, a metafísica tradicional (ou "domesticada", nas palavras dos autores) se ocuparia de unificar teorias a partir de uma renderização dos pedaços da ciência contemporânea. Em oposição a essa visão, os autores defendem que não parta de noções mereológicas caso se queira considerar alguma realidade objetiva, pois nelas a causalidade também "flui" de fora para dentro.

Há um sentido semelhante proposto por Morin (2015), quando apresenta três princípios para se pensar a complexidade. No primeiro, as complexidades seriam dialógicas, pois a ordem e a desordem, por exemplo, embora suprimam uma à outra, ambas colaboram e produzem a complexidade. Ao mesmo passo que não há complexidade sem a desordem, é da complexidade e da desordem que surge a ordem que confere alguma estabilidade à situação.

O segundo princípio sugere que as complexidades seriam recursivas. Na recursividade, os produtos de uma complexidade seriam motores causais de emergências ocorridas nessa mesma complexidade. Isso, ao mesmo tempo que só existam enquanto produto porque são produzidos pela complexidade. E é a essa complexidade produzida e produtora que será afetada por seus próprios produtos.

O terceiro princípio é o das complexidades sendo também hologramáticas. Em um holograma, uma parte, por menor que seja, informa sobre o total do objeto representado. Um holograma projeta sobre um conjunto maior de dimensões a informação originária de um conjunto menor de dimensões. A característica projetiva e ampliadora de um holograma balda a metáfora da contenção, pois ao mesmo tempo que uma imagem compõe o holograma, o holograma compõe a imagem.

Embora na proposta de Morin se esteja elaborando uma visão para a complexidade do pensamento e na proposta de Ladyman e colaboradores se esteja propondo uma radicalização da metafísica naturalizada, a intenção unificadora de ambos é notável. Os dois primeiros princípios se assemelham à via múltipla do "fluxo" da causalidade na 
metafísica naturalística radical. O terceiro princípio é também uma negação da mereologia inocente. Nesse princípio, o todo não é aquilo que contém as partes. O todo e as partes se confundem. O todo está nas partes, enquanto as partes estão no todo.

\subsubsection{Teoria Geral dos Sistemas}

Uma discussão semelhante, tanto das relações parte/todo quanto das possibilidades unificadoras e sua complexidade inerente, é feita no pensamento sistêmico, fruto do desenvolvimento de uma teoria geral dos sistemas (BERTALANFFY, 2010). Colocando em contraponto as disciplinarizações da ciência, Bertalanffy ressalta que a noção de "sistema" invadira todos os campos da ciência, tendo penetrado o pensamento popular e as comunicações em massa.

Para o autor (loc. cit.), a evolução da sociedade e das tecnologias demandam o pensamento a partir de sistemas. As ciências, sejam elas das cosias inanimadas, dos organismos vivos ou dos fenômenos sociais, passa a lidar com concepções e problemas situados em arranjos que não podem ser compreendidos a partir de uma investigação de suas partes, isoladamente:

Enquanto no passado a ciência procurava explicar os fenômenos observáveis reduzindo-os à interação de unidades elementares investigáveis independentes umas das outras, na ciência contemporânea aparecem concepções que se referem ao que é chamado um tanto vagamente "totalidade", isto é, problemas de organização, fenômenos que não se resolvem em acontecimentos locais, interações dinâmicas manifestadas na diferença de comportamento das partes quando isoladas ou quando em configuração superior.

(BERTALANFFY, 2010, p. 62)

A posição de Bertalanffy é também a de oposição às reduções mereológicas, na qual um sistema seria composto pela soma de suas partes, e mecanicista, de que as forças causais de um sistema estariam em seus constituintes elementares. Na esteira dessa crítica, cunha então o termo organísmico para se referir a situações "orgânicas", cujas compreensões dependeriam de um pensamento holístico. Uma mudança de foco do elementar para o sistêmico. 
Problemas de teorização da Biologia teriam um papel importante na gênese da teoria geral dos sistemas. O desenvolvimento de uma biologia organísmica, se iniciaria nos anos 20 (Sec. XX), tendo como exemplos marcante os trabalhos de Lotka (1920) e Volterra (1927). O entendimento biológico de um processo não se faria com o conhecimento sobre o predador ou sobre a presa, mas sim sobre o sistema predador-presa. As relações no sistema predador/presa e a variação populacional das espécies de um e de outro não podem ser explicadas nem pela mais detalhada e completa descrição de um e de outro. O sistema organísmico precisa ser a presa, o predador e (talvez principalmente) suas relações.

Enquanto teoria formal, a teoria geral dos sistemas se ocupa da busca por princípios válidos para os sistemas, independente de sua natureza. Pode assumir uma forma pormenorizada de disciplina lógico-matemática, mas cuja aplicação se transfere para disciplinas das ciências empíricas. Não por acaso, Bertalanffy sugere que outras teorias também de caráter lógico-matemático, mas de ampla aplicação em ciências empíricas, são também teorias de sistemas.

Algumas delas são: a teoria dos compartimentos, na qual são pensadas as possibilidades de transporte entre sistemas compartimentados em outros sistemas; a teoria da computação e da simulação, na qual são pensadas formas de se modelar e de se definir um sistema, podendo ser linear (de solução existente e fatigante) ou não-linear (insolúveis, exceto em casos especiais); a cibernética, que lida com controle em, e comunicação entre, sistemas; a teoria dos grafos $^{4}$, na qual se pensam as relações topológicas e estruturais ao invés das quantitativas; e a teoria das redes ligada à teoria dos grafos, dos compartimentos.

As duas últimas sugeridas são precisamente o cerne desta tese e da nossa proposta de pensamento sobre a complexidade da sala de aula. Falaremos da sala de aula complexa e das redes emergentes na sala. É interessante notar que a forma utilizada por Bertalanffy para definir o que seria um sistema recorre ao uso da expressão "complexo de elementos" e ainda recorre ao artifício imagético, com círculos e traços (Fig. 4). Isso indica uma influência de seu trabalho nas formas contemporâneas de representação de sistemas como

\footnotetext{
${ }^{4}$ o termo é nosso, considerado os sentido dado pelo autor, embora a opção do tradutor tenha sido o termo "gráfico", uma vez que o original em inglês graph assume as duas traduções
} 
redes, algo que tomamos para nos referirmos à sala de aula.

A caracterização de um sistema, então, pode se dar por seus elementos, por seus tipos de elementos (espécie) e pelas relações estabelecidas. Sistemas dos Tipos 1 e 2, (Fig. 4), são dotados de características somativas, ou seja, que se mostram idênticas dentro e fora do sistema. Isto significa dizer que é possível caracterizar o sistema a partir da observação isolada de seus elementos.

Figura 4 - Representação esquemática de diferentes tipos de sistemas hipotéticos

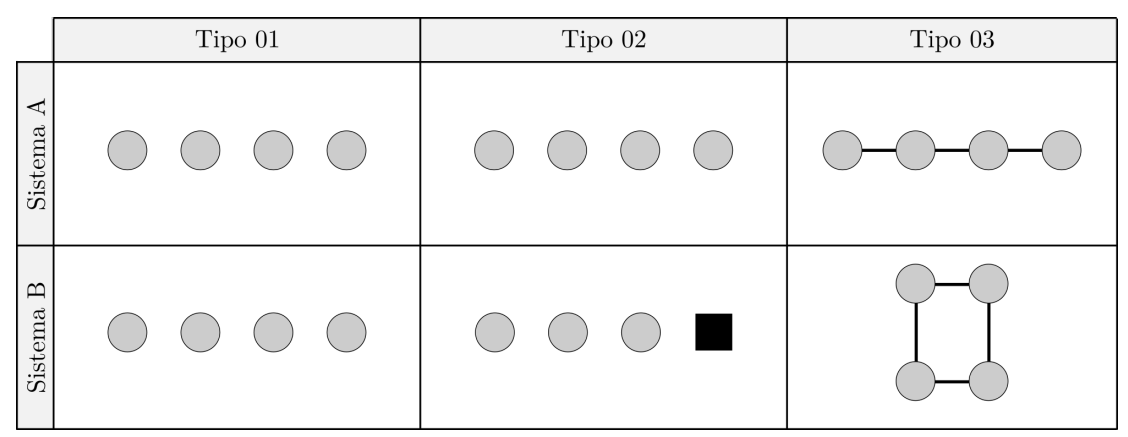

Fonte: elaboração nossa, adaptada de Bertalanffy (2010).

Já em sistemas do Tipo 3 (Fig. 4) as características do sistema são constitutivas, no sentido de que não basta conhecer os elementos do sistema, mas também as relações entre eles. Isso significa que as características constitutivas dependem das relações formadas no interior do complexo.

Utilizada largamente como um aforismo, a frase "o todo é maior que a soma das partes" então se apresenta na diferença entre aspectos somativos e constitutivos de um sistema. O complexo, constitutivo, apresenta características novas ou "emergentes" se comparadas às dos elementos, por sua vez somativas. Mesmo que conheçamos as características de cada constituinte, caso não sejam consideradas suas inter-relações, não podemos saber como é o comportamento do sistema. Entretanto, uma vez conhecendo as partes e suas relações, é possível que o comportamento do sistema seja derivado do comportamento das partes.

Desde a etimologia da palavra sistema a noção constitutiva e organizacional é 
presente. Derivada do grego, a palavra indica uma união de entidades que venham a interagir de maneira ordeira ou organizada (DEAMER, 2009). Para além da característica da nãosomatividade descrita acima, o pensamento sistêmico considera também a indissociabilidade entre parte e todo; a autorregulação que promove estabilidades no sistema; a absorção de aspectos externos por sistemas que sejam abertos, influenciando sua estruturação; a bilateralidade da relação entre elementos, o que promove a circularidade da causalidade, e ainda a possibilidade de diferentes condições iniciais produzirem os mesmos resultados no sistema, bem como condições iniciais idênticas produzirem resultados diferentes no sistema.

Bertalanffy reconhece que, embora seu programa de pesquisa e sua etiqueta de "teoria geral dos sistemas" tenham sido fundados por ele, outras propostas têm fundamentos e conclusões semelhantes. Dessas outras, a tectologia, de Bogdanov, é considerada como precursora das teorias de sistemas e da complexidade (MATTOS; DUDLEY, 2012). A tectologia também se propõe a uma visão sistêmica, ocupando-se das experiências organizacionais e de processos estruturais. Na tectologia, a mesma noção de que o todo é maior que a soma das partes é considerada, no que se classifica como complexos organizados. A diferença é que a tectologia considera também a possibilidade de que o todo seja menor que a soma das partes, nos complexos desorganizados e de que o todo seja a soma das partes, em casos de complexos neutros. Entretanto, um ponto de convergência claro, tanto da tectologia quanto da teoria geral dos sistemas é o viés unificador, que leva a uma visão holística, ou organísmica, nas considerações das realidades.

Na teoria geral dos sistemas isso é declarado de maneira explícita a partir de seus propósitos dados: há uma tendência geral de integração das ciências naturais e sociais; a integração se centraliza numa teoria geral dos sistemas; por essa teoria pode-se alcançar uma teoria exata nos campos não-físicos da ciência; a unidade das ciências seria aproximada pelo desenvolvimento de princípios unificadores que atravessem as ciências individuais; e isso poderia produzir uma integração muito necessária na educação científica. 


\subsubsection{Complexidade na síntese de unificação sistêmica de saberes}

A busca pelo desenvolvimento da teoria geral dos sistemas, de seus postulados e de seu estatuto epistemológico é tarefa interna dos "sistemicistas". Mas a influência dessa perspectiva de pensamento ou daquelas que o valham, como listadas acima, é marcante sempre que se nota a audácia de pesquisadores em tomar posturas unificadoras dentro da ciência.

Seja agindo dentro de seus campos de saber, propondo unificações intra-disciplinares ou aproximando seus campos de saber com outros, em unificações inter-disciplinares, a unificação não é um processo somativo, mas sim constitutivo. Não se basta descrever, por maior que seja o nível de detalhamento, o que um e outro saberes têm ou promovem. Trata-se no entanto de avaliar as relações entre eles e a partir delas lidar com questões novas que emergem dessas relações.

Pode-se tomar como exemplo de unificação, no qual a característica marcante fora uma ampliação holística do pensamento e a consideração sistêmica das relações entre duas áreas do saber, a princípio disjuntas, o que se observou na Biologia à década de 40 (Séc. XX). Um debate polarizava duas grandes correntes de pensamento dentro da Biologia, no início do Século XX, uma de orientação naturalista e outra de orientação experimentalista (ARAÚJO, 2001).

De um lado, influenciada pele teoria de Charles Darwin, (darwinismo), a corrente na qual a ideia central é considerar os mecanismos de seleção natural para explicar a origem, as transformações e perpetuação das espécies no tempo. No darwinismo, a explicação para a origem das espécies era marcada por uma abordagem naturalista. De outro lado, influenciada por Gregor Mendel (mendelismo) a corrente na qual a hereditariedade das características biológicas, suas continuidades e descontinuidades de características ao longo das gerações eram tomadas como foco. Em Mendel, a gênese das características eram observáveis experimentalmente, nos processos de hibridização. A marca da genética, então, era seu caráter experimental.

Nesse debate, uma tendência de predileção ao experimentalismo, de inclinação 
mendeliana, em detrimento ao naturalismo, de inclinação darwinista, se estabeleceu. Araújo (2001) remonta o descrédito do evolucionismo darwinista e sua ameaça de extinção, enquanto teoria, na década de 20 (Séc. XX), mostrando que o avanço da genética experimental alimentava o questionamento sobre qual seria a natureza das mudanças evolutivas. Mesmo que Darwin e Mendel estivessem interessados em entender as variações, havia uma diferença característica, pois os intervalos de tempo avaliados por Mendel eram menores e permitiam a experimentação. Os de Darwin, sendo intervalos geológicos, não permitiam experimentação. Por isso, para Darwin as mudanças seriam graduais e contínuas. Mas à evolução darwinista, faltavam as causas das variações e a explicação da herança de caracteres. Na genética de Mendel, ao contrário, as mudanças eram descontínuas e diferenças qualitativas eram verificadas experimentalmente.

Como em todo caso de debate acadêmico, não é possível atribuir mudanças históricas a apenas um ator. Mas pode-se olhar atores e produtos que tiveram influência saliente. No caso da unificação do debate apresentado acima, um desses casos salientes é visto na obra de Dobzhansky (1951), cuja escolha do título, Genética e a origem das espécies, já se apresenta como proposta unificadora dentro desse debate: "genética" é uma clara referência à corrente experimentalista mendeliana e "origem das espécies" apontando diretamente ao darwinismo, por sua vez de inclinação naturalista.

Da mesma forma que a visão organísmica é posta na teoria geral dos sistemas de Bertalanffy, o trabalho de Dobzhansky não é outro que não o de unificação. Unificação feita a partir de um pensamento relacional, e de uma proposta constitutiva da Biologia, do complexo de elementos experimentais e naturalísticos. Na esteira dessa transformação unificadora, uma nova forma de se pensar os processos evolutivos, agora incluindo especialmente as relações entre mecanismo de seleção e a genética, é fundada. As perguntas de pesquisa dos biólogos atinentes a essa nova visão surgem da relação entre esses dois campos: um todo de pensamento maior que a soma das vertentes que o formam. 


\subsubsection{Sistemas complexos}

Duas décadas antes da escrita desta tese, fora publicado um número especial da revista científica Science, exclusivamente dedicado a sistemas complexos. Nesse número Gallagher e Appenzeller (1999) apontam a predominância reducionista da ciência e de seus déficits evidentes provocados pelo crescimento sobrecarregante de informações e por especializações de disciplinas que criam suas sub-disciplinas, algo que promove barreiras para o fluxo de conhecimentos. Além disso, um outro problema provocado pelo reducionismo estaria no risco de ultra simplificação, como a "síndrome do gene do ..." que seria uma tentativa de se explicar resultados de processos multicausais a partir de uma unidade elementar genética responsável.

Um dos exemplos escolhidos pelos autores para ilustrar casos de ultra simplificação é a hipótese do "gene da preferência sexual". Gallagher e Appenzeller não poderiam prever o quão preciso fora o exemplo. No corrente ano, uma pesquisa em larga escala sem precedentes, procedida com mais de 470 mil indivíduos, veio confirmar o quão equivocado é o reducionismo da hipótese do "gene da preferência sexual" (GANNA et al., 2019).

Os resultados de Ganna e colaboradores mostram a existência de uma complexidade fenotípica em relação à preferência sexual. Essa complexidade é formada não por um, mas por muitos genes, embora não somente. Ainda, a complexidade da opção sexual estaria associada a uma variedade de outros fatores, como comportamentos externalizados, consumo de cigarro e cannabis e a disponibilidade ao risco e a novas experiências. Logo, uma opção sexual é produto constitutivo de muitos fatores, interdependentes e que não podem explicar isoladamente a opção tomada por um indivíduo.

Na visão de Goldenfeld e Kadanoff (1999), complexidade significa estrutura com variação. Por exemplo, organismos vivos seriam complexos por terem muitas partes diferentes em funcionamento, cada uma delas com variações dadas por processos semelhantes de codificação genética. Para o autor, a existência dos oceanos ou a observação do céu noturno são indícios de que no mundo físico há uma tendência natural de estruturação. Para os autores, a natureza pode produzir estruturas complexas a partir de situações 
simples. Mas por outro lado, mesmo estruturas complexas podem obedecer a leis simples: o clima é um tipo de estruturação altamente complexa, mas a ocorrência das estações do ano respeita um padrão muito simples.

Um sistema complexo é caracterizado pela conjunção de elementos independentes que interagem. E dessa interação, estruturante, algumas características podem ser abstraídas, conforme listam Ladyman, Lambert e Wiesner (2013). Uma delas é a não-linearidade, razão pela qual não se aplica o princípio da superposição para se pensar sistemas complexos. No princípio da superposição, típico da linearidade, a resposta resultante a um estímulo é a soma das respostas que seriam dadas individualmente por cada estímulo. A linearidade é somativa. A complexidade é constitutiva. Note-se que os autores informam que a não-linearidade não é condição necessária para a complexidade, pois matrizes lineares podem produzir redes complexas, informação particularmente aderente à presente tese.

Outro aspecto é a presença de feedback no sistema, que indica que a interação entre partes do sistema num instante posterior depende da interação ocorrida num instante anterior e isso retroalimenta o sistema. Para os autores, os ajustes de rotas migratórias dos pássaros são um exemplo adequado, pois cada pássaro se ajusta em relação a seus vizinhos próximos e ajustam sua própria posição, mas uma vez ajustando-se os indivíduos em relação aos próximos, todo o conjunto ajusta sua trajetória de migração.

Também os sistemas complexos exibem uma ordem espontânea, que implica na ocorrência de uma organização mesmo vinda de um grande número de interações descoordenadas. Embora definir o que é ordem seja muito difícil, os sistemas complexos estão no intermédio entre a aleatoriedade e ordem. Sistemas totalmente aleatórios não são sistemas complexos pois não se estruturariam em nenhum processo e nem produziriam retroalimentações. Por outro lado, os sistemas complexos não poderiam ser aqueles totalmente ordenados, pois eles seriam caracterizados por uma abordagem somativa.

Ainda, os sistemas complexos possuem também robustez e ausência de controle central. Em um sistema complexo, a ordem é dita robusta porque uma vez não sendo produzida centralmente mas sim distribuída, as perturbações que o sistema sofre não o desestabiliza por completo. A estabilidade e a robustez vem da distribuição do controle. 
Um ecossistema, por exemplo, pode se manter estável e pode ainda ser viável mesmo diante da ocorrência de perturbações, como uma catástrofe. Vale lembrar que a robustez nunca é absoluta, pois perturbações severas podem promover colapsos no sistema.

Em sistemas complexos, a emergência é outra característica marcante. Emergência estaria ligada às limitações do reducionismo. Comportamentos ou resultados inesperados em um sistema. Uma noção muito forte ligada à emergência é a causação "de cima para baixo". As causalidades "de baixo para cima" são possibilidades livres de controvérsias. Não se questionam os casos de que uma infecção bacteriana, ocorrendo em nível celular, promovam o falecimento de um indivíduo. Mas o surgimento de uma alteração bioquímica em um indivíduo, provocado pelo estresse que, por sua vez, fora provocado por um evento social é também uma possibilidade. Isso indica que sistemas biológicos, econômicos ou sociais não seriam causalmente fechados em relação à Física. Embora não se possa explicar as emergências em sistemas complexos a partir de um "fisicismo", também não se pode negar a relação entre aspectos físicos e não-físicos se falarmos em um sistema complexo. Mas essa relação pode se dar em níveis diferentes de organização.

Por isso, os sistemas complexos possuem também uma organização hierárquica. Não no sentido de uma estrutura que subjuga elementos em agregadores de ordem superior. Mas no sentido de que há organização estrutural em diferentes níveis e a causalidade flui de um nível a outro hierarquicamente mais amplo, bem como a outro hierarquicamente mais pormenorizado.

As características listadas por Ladyman, Lambert e Wiesner (2013) não resumem nem esgotam a noção de complexidade, nem tampouco propõem uma definição do que é um sistema complexo. Mas os autores nos ajudam a refletir que, por essas características, é possível identificarmos padrões que nos ajudem a pensar sobre a complexidade dos sistemas. Padrões se apresentam de maneira notável na complexidade da natureza. As rotas de voo dos gansos, os favos com tesselação hexagonal das abelhas ou as formas espirais dos girassóis e das galáxias. Padrões emergem o tempo todo no mundo natural, sendo detectáveis e passíveis de análise. Para os autores: 
O estudo científico de padrões que ocorrem naturalmente requer tanto significados adequados para representar formalmente esses padrões, quanto um método para inferir padrões a partir de dados que coletem características objetivas do mundo.

(LADYMAN; LAMBERT; WIESNER, 2013, p. 63, tradução nossa)

O que Ladyman e colegas nos parecem dizer é que, partindo de um modelo representativo, constituído de elementos retirados do sistema em si, e abraçando um quadro interpretativo que crie nexo para as inter-relações entre esses elementos, é possível fazer com que os padrões sejam detectados. Isto significa que o caminho para o entendimento dos cenários dotados de complexidade passa pelo uso de sistemas de representação, que devem se valer de traços objetivos extraídos do tipo de realidade que se deseja explorar, para então se lançar mão de um quadro interpretativo, dentro do qual os padrões façam sentido.

Há uma possibilidade promissora na captura de características objetivas do mundo e na produção de modelos que permitam a interpretação de estruturações complexas. Mas nisso, há que se avaliar as limitações que os termos modelo e complexo impõem, conforme ressalta Cilliers (2001). Primeiro, utilizando a palavra "modelo" em um sentido estrito, como o processo de produção de referentes ligados à realidade, mas que refletem apenas parcialmente essa realidade. Para Cilliers (ibid.), o problema de fundo dos modelos de complexidade é que não importa como o modelo seja construído, ele será falho e, pior, é impossível saber de que forma ele será falho. Depois, atenta para a redução de complexidade que é inerente aos modelos:

Nós não podemos lidar com a realidade em sua complexidade total. Nossos modelos precisam reduzir essa complexidade, no sentido de produzir algum entendimento. No processo, algo é obviamente perdido. Se tivermos um bom modelo, nossa esperança é de que aquilo que foi deixado de fora é menos importante

(CILLIERS, 2001, p. 137, tradução nossa)

Há, então, sempre um risco de supervalorização de um modelo que nos permita lidar com a complexidade de um sistemas. Nossa concordância com Cilliers nos faz olhar sempre de maneira animada, mas reticente em relação à capacidade explicativa de um modelo. 
Mas, ao mesmo tempo, certos de que, sem alguma redução da complexidade, imposta pelo modelo, a construção de racionalidade sobre o sistema em si se torna impossível. O autor explicita que esse argumento não é de oposição à construção de modelos, mas sim uma declaração de limitação que deve estar sempre à vista.

Os sistemas complexos não são nem caóticos nem homogêneos. Então, eles possuem estruturas que ganham corpo a partir dos padrões de interação entre seus componentes. Logo, os modelos dos sistemas complexos tratam de capturar essas estruturas dos sistemas complexos. Algumas estruturações são perenes e mais fáceis de se capturar. Outras são, nas palavras de Cilliers, voláteis ou efêmeras. As estruturas ainda estão relacionadas de maneira complexa. E além disso, pelo fato de as estruturas se apresentarem em diferentes escalas, a definição de limites entre as estruturas é problemática.

Em um sistema complexo, as estruturas são emergentes. São estruturas que emergem em sistemas abertos, cuja importância das relações é, tipicamente, maior do que a importância dos componentes em si. São sistemas cujas bordas limítrofes não podem ser claramente definidas. Então a definição das bordas de um sistema complexo depende, simultaneamente, da função desempenhada pela atividade do próprio sistema bem como da estratégia utilizada para descrever o sistema. Isso coloca os sistemas complexos com bordas que não são nem puramente fruto da nossa descrição nem puramente uma ocorrência natural. O encapsulamento de um sistema complexo não é algo que se possa descrever objetivamente.

Um outro ponto que Cilliers chama a atenção é que a não-linearidade, inerente à complexidade, nos impede de saber qual é a cadeia causal de um evento. A importância de certos elementos ou de certas relações não pode ser prevista, a priori. Isso se aproxima da noção de frustração descrita por Oliveira (2008). Uma vez que os sistemas podem ter comportamento complexo, mesmo sendo estruturado por muitas unidades simples, porém interligadas entre si, o comportamento de cada unidade influencia as outras e influencia os sistema.

Na evolução dinâmica do sistema, o conjunto de influências mútuas aumenta. Com isso, cada unidade adapta seu estado, à mercê das influências das outras, rumo a 
otimizar algum parâmetro. Como essas influências, por vezes, são conflitantes, cada unidade cria o que Oliveira chama de solução de compromisso, acatando algumas solicitações e descartando outras.

Oliveira está tratando de unidades elementares cujos comportamentos sejam relativamente simples, conhecidos como autômatos celulares. O exemplo que ele utiliza para soluções de compromisso é o caso do vidro de spin e o chamado modelo de Ising. Em um ferromagneto, todos os spins tendem a se orientar da mesma forma. Num vidro de spin, a interação entre spins se dá aos pares e a energia pode ser minimizada ora para pares de spins com a mesma orientação, ora para pares com orientação oposta. Em processos de resfriamento lento, cada spin satisfará algumas das relações de interação com seus vizinhos e outras não, formando uma configuração que emerge de relações diádicas locais e temporárias e de uma estabilidade longeva ou de uma propriedade global. Isso promove uma frustração, pois diferentes estados finais de energia mínima são atingidos a cada repetição de experimentos de resfriamento com vidro de spin.

Oliveira estende a noção de soluções de compromisso para áreas outras áreas, como a economia. Na complexidade da economia, um produto final, lançado no mercado, depende de uma série de soluções de compromisso durante sua produção. A decisão dos consumidores de adquirir ou não um produto depende de outra série de soluções de compromisso. De mesma forma, conjuntos de indivíduos, (i.e. agrupamentos sociais), também multiplicam suas demandas conflitantes à medida que evoluem como sistema, o que demanda soluções de compromisso por parte de cada integrante. Isso impede predições causais feitas a priori.

Ampliando o exemplo de Oliveira, podemos observar economistas contemporâneos, que jamais ignoram o fato de que mudanças num cenário político são capazes de provocar queda ou furor em bolsas de valores. Joalherias finas, há muito, já se valem do fato de que uma situação emocional local, seja de euforia, seja de insegurança, em relação a um relacionamento amoroso pode leva um consumidor a ter uma postura menos racional na decisão de consumir uma joia. Ou também biólogos, aliando um período glacial a mudanças do nível dos oceanos junto a uma plataforma continental, propondo uma explicação para 
a expansão de uma área florestal numa época e num local improváveis.

Emergências em escala de sistemas são multicausais. Mas podem ser originárias de soluções de compromisso tomadas em resposta a demandas conflitantes, na escala de elementos. E essas soluções de compromisso podem ser responsáveis por diferentes cenários resultantes. Frustram a expectativa de uma causalidade determinada a priori. Frustram a repetibilidade.

As emergências então operam sob uma multiplicidade, pois não é possível determinar, a partir de uma observação de padrões manifestos, quais são as configurações ocorridas na escala de elementos que engatilham estruturas emergentes em nível sistêmico. Diferentes configurações podem resultar no mesmo tipo de emergência. Mas as emergências tem alto grau de frustração, pois a mesma configuração inicial pode resultar em diferentes emergências. Entretanto, o entendimento das estruturas que emergem passa, como dito antes, pela necessidade de modelos representativos. Mesmo com as objeções apresentadas anteriormente, os modelos habilitam interpretações sobre o sistema que podem apontar sua função e sua estrutura.

\subsubsection{Complicado ou complexo?}

A complexidade é abordada por Kurtz e Snowden (2003) que propõem um quadro de trabalho para tomada de decisão. Os autores separam os problemas (ou situações) sobre as quais se querem produzir sentidos. Ao se pensar estratégias para resoluções de problemas e tomada de decisão, sugere-se analisar quatro possíveis tipificações possíveis. Os problemas podem ser

- conhecidos, nos quais as relações causais são visíveis e predizíveis, as soluções são legitimadas por boas práticas, pois a reprodutibilidade é característica;

- conhecíveis, nos quais a causa e o efeito estão separados no tempo, as soluções são obtidas por postura analítica e planejamento de cenários possíveis e uma visão sistêmica é suficiente; 
- complexos, nos quais as relações de causa e efeito só podem ser conhecidas em retrospecto, as soluções são obtidas por gerenciamento dos padrões emergentes e por adaptação;

- caóticos, nos quais as relações de causa e efeito não podem ser percebidas, nem em retrospecto, e por isso não se propõem soluções mas somente ações de estabilidade.

O quadro de trabalho dos autores é proposto para que cenários complexos sejam entendidos com sua causalidade emergente, impossível de ser determinada a priori. Batizado pelos autores de Cynefin, o quadro de trabalho utiliza uma palavra de origem galega e tem como tradução algo que remete a uma situação na qual a justiça é falha. Isso porque na avaliação de situações e na tomada de decisão, muitas vezes pela não linearidade, pela robustez e pela retroalimentação, não se tem um modelo que possa ser previamente adequado. Para os autores, na perspectiva Cynefin é adequado entender um cenário real como sendo:

local de nossas múltiplas afiliações, no sentido de que todos nós, indivi-
dualmente ou coletivamente, temos muitas raízes, sejam elas culturais,
religiosas, geográficas, tribais ou outras. Não podemos nunca nos dar conta
da natureza dessas afiliações, mas elas influenciam profundamente quem
somos. [...] todos as interações humanas são fortemente influenciadas e
frequentemente determinadas pelos padrões das nossas múltiplas experi-
ências, tanto influências das experiências individuais, quanto influências
das experiências coletivas, expressas como histórias

(KURTZ; SNOWDEN, 2003, p. 467, tradução e grifo nossos)

Tanto para pensar o ensino de Ciências, quanto para pensar os designs de pesquisa, a proposta dos autores é oposta às noções de redução e de disciplinarização, que são pensadas e aplicadas para cenários ordenados e organizados. Para os autores, em um domínio organizado, o foco se direciona à eficiência, pois os sistemas mais organizados são afins de abordagens reducionistas; são somativos e têm o todo como soma das partes. Entretanto, em sistemas não-ordenados, a característica constitutiva se sobressai e o todo nunca é a soma das partes.

O exemplo dado pelos autores é um teste de final de semestre em uma escola de marinheiros, norte americana. A prova-teste era colocar o grupo de militares para tomar 
conta de um horário de recreio em um jardim da infância. Os militares tiveram tempo de preparação. E utilizaram esse tempo para planejar ações, definir claramente os objetivos, propor práticas e planos-B. A atitude dos militares foi a de ordenar o cenário e organizar a brincadeira das crianças, baseados em princípios típicos do design. Como consequência, obtiveram o caos.

Figura 5-Quadro de trabalho Cynefin e tipificação de situações e problemas

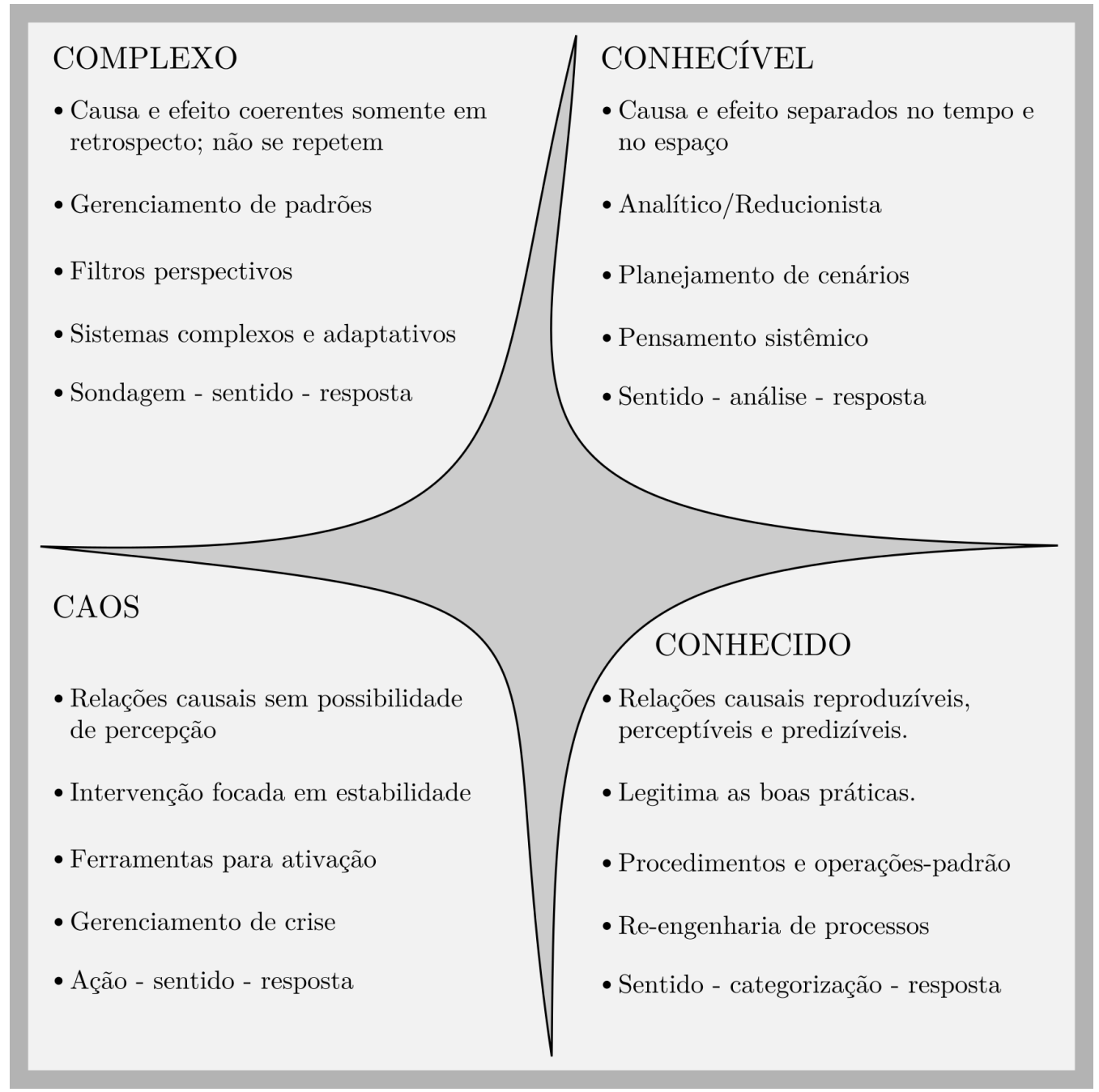

Fonte: elaboração e tradução nossas, adaptado de Kurtz e Snowden (2003).

No entanto, observando as professoras e os professores, os militares perceberam que aqueles que possuíam mais experiência, tendiam a permitir maior liberdade, no início do recreio, e intervinham no sentido de estabilizar os padrões desejáveis e desestabilizar 
os padrões indesejáveis. Aqueles professores mais atentos, criavam espaços para que os padrões desejados fossem mais propícios.

Em situações reais, inerentemente complexas, por vezes caóticas, a tomada de decisão não pode ser guiada por práticas pré-estabelecidas. As interpretações não são feitas de maneira preditiva. Os planos de ação dependem primeiro daquilo que emerge do sistema (Fig. 5, à esquerda). Diante do real não-ordenado, reforçam os autores, cada intervenção é também um momento de produzir diagnósticos. Ao mesmo tempo, cada diagnóstico é também um momento no qual se intervem. Os atos mudam a natureza do sistema. Por isso, algum grau sub-ótimo de funcionamento de cada componente do sistema deve ser permitido, de modo que o sistema, como um todo, possa ter seu comportamento otimizado.

O exemplo dado se refere à atuação docente. A lida com a realidade da sala de aula mostra tal realidade, e dá indícios das razões pelas quais uma atitude controladora de uma professora ou professor não são garantias de uma aula com alunos produtivamente engajados. Mas podemos também considerar o quadro de trabalho Cynefin para pensarmos os designs de pesquisa que se valham das redes.

Sistemas reticulados, complexos, não possuem estruturas formadas por categorias pré-definidas. Assim, as redes não se repetirão, as estruturas serão dinâmicas e cada arranjo será contingente. Nem tampouco as representações e os produtos culturais poderiam ser impostos. São outras emergências cujas causalidades só poderiam ser detectadas pelo retrovisor. Por isso, mesmo que a turbidez na qual se misturam representações do que é científico e representações do que é senso-comum não seja um estado ótimo da ciência formal, é nessa turbidez que se dá o desenvolvimento cultural dos alunos. Nesse sentido, uma noção de estruturas e de processos culturais pode ser obtida para agrupamentos microssociais.

\subsubsection{Complexidade em contextos microssociais}

Ao pensarmos os conceitos inerentes a sistemas complexos como a frustração, a emergência e a robustez e outros, vislumbramos uma proximidade a complexidade na 
Teoria de Eventos proposta por Sewell (2005). Nela, a não-linearidade da complexidade é o elemento central promovedor da não reprodutibilidade de fatos sociais. O poder associativo das relações humanas exige que pensemos estruturas nunca num sentido somativo, mas no sentido constitutivo, que abordamos anteriormente. Mesmo considerando cenários idênticos, não se pode construir um modelo causal da história, pois os eventos são emergências que dependem tanto dos agentes quanto das estruturas dentro nas quais os atores estão e às quais os atores dão forma.

A influência do pensamento sistêmico na análise de eventos em cenários reais, promove uma associação entre o conceito de sistema e o conceito de estrutura. Ambos assumem usos muito semelhantes, quando referidos a aglomerados sociais ou a algum tipo de organização. Mostramos acima a versatilidade do termo sistema, que promove sua polissemia. De maneira semelhante, para Sewell (ibid.), a noção de estrutura utilizada nos contextos sociais é também polissêmica. O uso do termo estrutura opera mais como metáfora epistêmica do que como conceito preciso. Em linhas gerais, estrutura pode ser pensada como sinônimo de padrão. Mas isso não é uma via de mão dupla: padrão não tem a mesma força retórica que estrutura. Estrutura empodera aquilo à qual o termo se emprega. Nas relações de poder, por exemplo, o uso do termo estruturante é utilizado num sentido e com uma força retórica que o termo padronizante não poderia ter.

Pensando as relações sociais, estrutura é um termo empregado para se referir a um fato que, não raramente, se tenta negar: há uma tendência da ocorrência de padrões em agrupamentos sociais. Não num sentido inocente de que estrutura seria um conjunto de elementos cujos poderes causais seriam rígidos e promovedores de previsões determinísticas. Nem tampouco padrões que pudessem ser reveladores de um "modelo elementar padrão" dos agrupamentos humanos. Mas sim padrões, ou estruturas, que emergem das relações entre os humanos que constituem a estrutura. Os padrões ocorrem independente das vontades ou das percepções dos indivíduos que compõem um grupo. Mesmo que sejam padrões dinâmicos e não-reproduzíveis e mesmo que os atores possam variar seus papéis nas estruturas que eles mesmo padronizam, não veremos relações sociais sem nenhuma estruturação. 
Há uma diferença, argumenta Sewell, entre o uso de "estrutura" quando feito por sociólogos e quando feito por antropólogos. Para sociólogos, estrutura estaria em contraste com cultura. Nessa perspectiva, a estrutura seria a parte material, dura. A estrutura seria a base sólida sobre a qual se apoia a cultura. Esta última, por sua vez, seria a parte soft, o mental. Já para antropólogos e outros cientistas sociais de inclinação semiótica, o termo estrutura se refere ao reino da cultura. A estrutura seria o emaranhado de desdobramentos de onde emerge a cultura. As duas perspectivas podem ser ditas estruturalistas, mas conferem sentidos incompatíveis ao termo.

Tomar estrutura como sendo a parte dura sobre a qual a cultura se assenta, significa por a estrutura como impermeável à ação humana. A crítica de Sewell é que, se assim fosse, a ação humana nada mudaria na estrutura e os atores seriam reduzidos a autômatos bem programados. Neste caso, os padrões da vida social seriam estáticos. Mas a fraqueza de se tomar a estrutura como rígida é que faltariam elementos que explicassem o dinamismo observado nas relações sociais.

Mesmo tomando como fato a influência que as estruturas das relações sociais têm sobre os atores que a compõem, isso não significa que as estruturas tenham poder de constranger absolutamente seus atores componentes. Se assim fosse, teríamos uma repetibilidade de eventos sempre que identificássemos a estrutura. Mas isso não se verifica.

A proposta de Sewell é que o termo estrutura ou padrão - ambos muito próximos daquilo que trataremos como redes - demanda um delineamento teórico adequado, de modo a dar conta da agência dos atores sociais sobre as estruturas. Da mesma forma que os sistemas complexos apresentados promovem causalidades constitutivas, que vão de dentro pra fora e ao mesmo tempo de fora pra dentro do sistema, as estruturas de Sewell têm caráter dual. A estrutura constrange os atores mas os atores agem na estrutura. Como isso acontece num complexo, não se pode assumir previsão causal dos eventos.

A visão dual das causalidades nas estruturas, utilizada por Sewell, nos remete à visão organísmica proposta na teoria geral dos sistemas, desenvolvida tempos antes. Mas uma origem da noção de dualidade aplicada a agrupamentos humanos está no trabalho de Giddens (1986). Para Giddens a sociedade é um termo tipicamente utilizado com dois 
significados.

Num sentido, sociedade no sentido de associações, de interações, no qual há uma "[...]tendência de entender 'sistema social' numa relação conceitual próxima com sistemas biológicos, com corpos, com organismos (GIDDENS, 1986, p. 196, tradução nossa). Nessa significação de sistema social, a estabilidade e as mudanças são governadas por questões internas ao sistema. No outro sentido, sociedade se refere a unidade sociais que teriam algum tipo de borda claramente demarcada no espaço e no tempo, e que separaria umas unidades de outras. Neste segundo senso, a ideia aplicável é a existência de relações inter-societais.

Sem polarizar essas duas formas de se pensar o social, Giddens advoga pelo uso de ambas, a interação entre grupos viola ambas as premissas de caracterização. Se pensarmos em termos de unidades societais como sendo bordeadas no espaço/tempo, seus limites podem ser violados pela interação com outras unidades societais. Na outra mão, se pensarmos sociedade em termos de organismo, devemos considerar as possibilidades causais do organismo, seja dos elementos para o todo, seja do todo para os elementos. Mas ainda assim, não se pode desconsiderar que nenhum organismo está isolado do entorno. Por isso, a existência da borda nos permite falar em "interno e externo" ao sistema social. Mas ao mesmo tempo, a borda, uma vez existindo, sempre será permeável e com isso sempre permitirá alguma entrada daquilo que é externo a ela.

Em um sistema, a reprodução está associada à estabilidade na estrutura, enquanto a mudança está ligada ao dinamismo da estrutura. Seja na dualidade proposta por Giddens, seja em sua utilização feita por Sewell, reprodução e mudanças são processos que acontecem concomitantemente. Suas causas não podem ser atribuídas exclusivamente ao que se está interno ao sistema, pois não existe estrutura social absolutamente hermética. Também suas causas não podem ter origem exclusivamente externa, pois não há imposição de uma força causal que impeça que os atores de uma rede (de uma estrutura, por enquanto) ajam, resistindo ao externo ou ajam ajustando-se a ele.

Giddens reforça a noção de dualidade ao propor uma teoria de estruturação da sociedade, criticando a ideia de que uma estrutura constrangeria absolutamente os 
indivíduos. Para Giddens, as estruturas tem poder de constranger, mas, ao mesmo tempo, a estrutura habilita os atores que compõem o sistema social a colocarem suas ações em prática, a agirem.

A consequência disso é que a estrutura é formada por seus atores sociais mas é transformada pela ação deles. Afinal, é a repetição das práticas das pessoas que promove uma estrutura. Mas à medida que essas práticas se repetem, elas sofrem ligeiras distorções, perturbando a estabilidade da estrutura. Na atuação social, os partícipes lançam mão daquilo que têm à disposição e que vem a operar como um recurso para performarem socialmente. Mas isso se dá segundo um conjunto de regras estabelecidas pela estrutura que emergiu e que definiu essas regras. Giddens resume as estruturas ao conjunto de regras e recursos que estão envolvidos na articulação institucional dos sistemas sociais.

Tanto os recursos quanto as regras, propostas por Giddens, operariam na esfera virtual. Mas, considerando que os atores performam num mundo repleto de recursos materiais, Sewell propõe um ajuste à ideia de Giddens: que as regras, de Giddens, sejam pensadas como esquemas de ação que são, necessariamente, virtuais. Esses esquemas poderiam ser ou transpostos de um cenário social para outro. Seriam generalizáveis; e que os recursos sejam tanto materiais como artefatos, ou imateriais, como uma destreza, por exemplo. Quando colocados em ação, os recursos permitiriam, via performance social, a realocação dos atores na estrutura, o que mudaria a mesma.

Esse ajuste permite lidarmos com as mudanças e com a estabilidade das estruturas, a partir da ação dos agentes que a formam. A dualidade entre agência e estrutura, de Giddens, é mantida. E a ação dos atores, na teia de relações que estabelecem, é o que muda intra e inter socialmente, os padrões, as estruturas.

Como nossas estruturas (ou sistemas ou, mais à frente, nossas redes) emergem da sala de aula, estaremos operando em uma escala diferente dos domínios institucionais ou estratificações macrossociais. Uma escala mais detalhada, pois nosso agrupamento social de interesse tem suas estruturações constituídas pelos participantes da sala de aula. Isso coloca os atores daquela realidade social (alunos, professor e pesquisador) num jogo microssocial. O argumento que autoriza o movimento de se trazer para o micro um 
conjunto de noções pensadas para o macro é dado pela noção de encontros.

Os encontros são uma tradução lógica macro/micro proposta por Collins (1981). Nos encontros, as relações sociais são pensadas em termos da vida cotidiana: o quê as pessoas fazem e como as pessoas agem. Em nível microssocial, os elementos em circulação aglutinam os atores mas não permeiam uma realidade consciente dos indivíduos. Collins afirma que, em situações cotidianas, as pessoas se comportam de uma maneira não explicada como produto de uma lógica racionalista delas.

A dinâmica das situações cotidianas e a cola social que uns e outros estabelecem, são produtos de decisões sub-cognitivas. Não há temporalidade hábil que permita a um ser humano processar racionalmente todas as variáveis que estejam a seu alcance e com elas racionalizar se decidirá fazer parte ou não de um certo agrupamento de pessoas em uma situação cotidiana.

Mas Collins não sugere que as colas sociais ocorram cegamente, como se fossem um tipo de efeito manada. O ponto que ele defende é que a quantidade de sutilezas que formam essas colas é tamanha e, de tanto, são reconhecidas por um tipo de compartilhamento também sutil, como o compartilhamento de emoções ou de rítmicas de interação. Esses compartilhamentos em pequenos agrupamentos sociais têm traços comuns aos sistemas complexos: eles retroalimentam o grupo e isso ajusta o grupo. Com isso, se estabelecem rituais de interação que se desdobram em cadeias.

Isto significa que qualquer processo de formação de agrupamentos ou de inclusão/exclusão de membros de um agrupamento se dá nas interações, sob esses acordos velados. Ao estimularmos a formação e produzirmos representações explícitas das redes sociais da sala de aula, estamos buscando fazer com que esses acordos velados, ou traços deles, sejam vistos.

É nesse sentido que os sistemas complexos podem ser pensados como redes. Que suas estruturas podem tomar a forma imagética de grafos. Que uma lógica pode ser construída sobre as emergências. Nossas complexidades passam a ser pensadas e vistas por nossas redes. 


\subsection{Mares de Redes}

O pensamento em redes é algo que, sistematicamente, se remete a sistemas complexos. Mesmo a definição do que seria um sistema complexo pode ser feita em referência às redes. É o que faz Mitchell (2006):

Não há uma definição formal de "sistema complexo" que seja amplamente aceita. Informalmente, um sistema complexo é uma grande rede de componentes relativamente simples, sem um controle central e na qual um comportamento complexo emergente é exibido

(MITCHELL, 2006, p. 1195, tradução e grifo nossos)

Mitchell deixa claro que essa não é uma definição formal e que muito há a se pensar sobre o que significaria "componentes relativamente simples" ou o que significaria um "comportamento complexo emergente". Quando se remente a componentes relativamente simples, não se está negando a escala de complexidade que nos permitiria pensar cada componente. Bem como quando se remete a comportamento complexo, não se trata, apenas, do sentido de comportamentos complicados e difíceis de serem descritos.

Sobre componentes relativamente simples, Mitchell fala no sentido de seus papéis funcionais em relação ao comportamento coletivo da rede. Em um esporte coletivo, por exemplo, é inegável que cada atleta seja em si um sistema complexo, uma rede. Mas, para efeitos de análise do papel funcional ou estrutural, na rede, é possível tomar posição que cada esportista ocupa e sua função desempenhada, naquela posição. Com isso, torna-se possível analisar as emergências ocorridas no esporte praticado a partir da representação dessa rede. E, ao se analisar essa rede, o coletivo produz a emergência, enquanto cada atleta tem uma função operacional relativamente simples.

Já em relação ao comportamento complexo emergente, o sentido é de que o comportamento da rede como um todo depende das ações dos componentes e a relação entre essas ações e o todo não é trivial. Isso remonta o argumento da não-linearidade e da não-somatividade. Pensando o exemplo esportivo, o mesmo time, com os mesmos atletas pode performar de maneira muito diferente em duas competições idênticas. 
O comportamento global de um sistema complexo (da rede) é caracterizado em termos dos padrões formados e da informação que esses padrões podem processar. Entretanto o processo de formação de padrões e de processamento de informação é adaptativo ao sistema (o que remete à retroalimentação). O sucesso no processo de informação pelos padrões emergentes aumenta num sentido evolutivo, em contextos de competição.

Esse sentido evolutivo dado por Mitchell indica uma relação entre o pensamento em redes e a noção de ecologia, num sentido lato. Em sentido estrito, ecologia se remete a todos os seres vivos e às relações entre eles. Mas o termo ecologia tem seu sentido expandido, sendo utilizado em outras áres, quando passa a se referir as redes representativas de um arranjo complexo.

Esse sentido lato é extremado por Capra (1996), que propõe uma ecologia profunda como forma de pensar a relação existente entre todos os fenômenos, individuais, sociais e naturais. Embora isso esteja muito próximo da noção holística de completude, Capra sugere uma separação sutil nos significados do que seria holístico do que seria ecológico.

Numa visão holística, para Capra, uma entidade, como uma bicicleta, seria considerada em seu todo funcional e a partir de como as peças trabalham juntas para o funcionamento. Mas isso não é a ecologia profunda da bicicleta. Numa visão ecológica profunda, a bicicleta seria sim um todo intra-ligado em si, mas seria também considerada em seu ambiente natural - de onde são minerados os insumos que resultam nas peças da bicicleta - e social - onde se estabelece a comunidade que coloca a bicicleta em uso.

Embora a proposta de Capra seja mais audaciosa que a nossa nesta tese, é interessante, para nós, o sentido que ele propõe em relação às redes e às ecologias:

$\grave{A}$ medida que o conceito de rede se tornou mais e mais proeminente na ecologia, pensadores sistêmicos começaram a usar modelos em redes para todos os níveis de sistemas, passando a ver organismos como redes de células, de órgãos e de sistemas de órgãos da mesma maneira que ecossistemas passaram a ser entendidos como redes de organismos individuais. De maneira correspondente, os fluxos de matéria e de energia através dos ecossistemas eram percebidos como o prolongamento das vias metabólicas através dos organismos.

(CAPRA, 1996, p. 35, tradução e grifo nossos) 
A visão de completudes da complexidade como ecologias e de ecologias como redes implicaria, para Capra, numa nova forma de se pensar hierarquias. Essa nova forma de Capra coloca as hierarquias numa noção mais parecida com as organizações hierárquicas de Ladyman, Lambert e Wiesner (2013), que não tratam da agregação por sub-soma dos elementos de menor ordem subjugados a guarda-chuvas dos elementos de maior ordem. O sentido de hierarquia é o da existência de organizações estruturais inerentes a cada elemento que produz uma organização estrutural em escala maior.

Assim, o autor sugere que em qualquer nível que se observe, sistemas vivos são redes. Redes que interagem em rede com outras redes, ou seja, com outros sistemas. Cada ponto da rede é também uma rede, se olhado de maneira ampliada. Mesmo a tendência de construir arranjos que contenham redes dentro de redes é, para Capra, uma projeção humana. Vemos essa crítica semelhante à crítica da metáfora da contenção que discutimos anteriormente. Para o autor, em um sistema hierárquico, a organização se dá na forma de pirâmide, com os maiores ou os agregadores, colocados acima e os menores, os agregados, colocado abaixo. Mas na natureza não haveria tal distinção entre acima ou abaixo, mas sim redes que estariam aninhadas em outras redes.

\subsubsection{Redes e ecologias: uma teoria da aprendizagem, reconsiderada}

O pensamento da complexidade e suas metáforas teóricas das ecologias e das redes, espinha dorsal desta tese, foi também motor de um debate acadêmico acerca do desenvolvimento conceitual no ensino de Ciências. A inclusão da complexidade fora elemento-chave para reorganização de toda uma corrente de pensamento e de um programa de pesquisa em aprendizagem.

O frenesi da chamada revolução cognitiva colocava os modelos de aprendizagem em voga à virada da década de 70 para 80 do século XX. À época, uma corrente vigente da teoria pós piagetiana da Mudança Conceitual, se consolidava. Essa corrente que figurava, chamemos, a primeira geração da Mudança Conceitual, tinha como um dos principais aportes o trabalho de Posner et al. (1982). As ideias materializadas naquele trabalho defendiam um modelo para a Mudança Conceitual, ou seja para a aprendizagem, como 
rupturas ou como momentos dramáticos em situações específicas, análogas aos problemas exemplares de Kuhn (1962), que transformariam a forma de um indivíduo conceber uma dada situação, particularmente pelo conflito cognitivo.

Esse modelo propunha o aprendizado como análogo às revoluções científicas (KUHN, 1962) ou análogo às mudanças nos programas de pesquisa (LAKATOS, 1970). A partir de uma insatisfação provocada pela inadequação de um novo conhecimento em relação a uma concepção existente, uma anomalia se apresentaria e uma mudança de paradigma (ou de programa de pesquisa) do estudante poderia acontecer. Desde que a nova concepção fosse inteligível, inicialmente plausível e frutífera à formação de um novo programa de pesquisa, uma nova concepção se formaria e seria incomensurável com a anterior.

O suporte de fundo do trabalho de Posner e colaboradores sustenta - ou ao menos indica - um aprendizado ocorrendo por ruptura com uma concepção pré-existente. Essa forma de se pensar a Mudança Conceitual em sua primeira geração, que chamaremos de modelo kuhniano, se torna influente e pode ser reconhecida em uma sorte de desdobramentos acadêmicos. Carey (1999), por exemplo, avalia mudanças no sistema do conhecimento como um processo que passa por um enriquecimento do conceito sem alteração de seu núcleo até uma evolução de um grupo de conceitos em outro, que é incomensurável com o original.

A noção kuhniana de incomensurabilidade também é vista no trabalho de Wiser (1995) no qual um paralelo com a História da Ciência, de forma semelhante à proposta de Posner et al. (1982), seria uma estratégia adequada para remediação de concepções não científicas dos estudantes. Menos explicitamente, Vosniadou e Brewer (1992) sugerem que são os modelos mentais e os quadros teóricos dos estudantes que estariam em processo de mudança: nos modelos mentais a mudança ocorreria mais facilmente, já os quadros teóricos, semelhantes aos paradigmas kuhnianos ou aos núcleos teóricos lakatianos, seriam mais coerentes e estruturados e, por isso, menos suscetíveis à mudança.

A crítica ao modelo kuhniano para uma Mudança Conceitual recaía sobre a constatação de que, mesmo confrontados com novas ideias, mesmo dentro das condições propostas por Posner et al. (1982), a incomensurabilidade de uma nova concepção com 
a anterior se mostrava problemática. A realidade escolar indicava que, mesmo diante de uma série de conflitos, as concepções antigas continuavam sendo acionadas pelos alunos.

Numa outra vertente, em contraponto às ideias de Kuhn da primeira geração da Mudança Conceitual, têm os trabalhos apoiados na epistemologia proposta por Toulmin (1967). Para Toulmin, as ciências naturais se desenvolveriam num processo análogo à evolução em um sistema ecológico (redes). Isto significaria colocar o desenvolvimento da ciência como um processo incremental, complexo, resultante da relação entre elementos num sistema, sem causalidades a priori. Em Toulmin, os elementos dessa ecologia, análogos a espécies, seriam variantes intelectuais em constante interação e competição.

Se, num sistema ecológico, há, de geração em geração, um processo seletivo, num sistema intelectual, as constantes revisões de comprometimentos e de assunções feitas fariam esse processo. A cada ciclo de revisões, elementos dessas variantes intelectuais que fossem mais viáveis ao sistema de conhecimento, ou seja, à Ecologia Conceitual, seguiriam a diante à guisa da extinção de outros. A cada ciclo de revisões, novas variantes intelectuais seriam aceitas e incorporadas às considerações da Ciência enquanto umas poderiam ganhar importância no sistema, outras poderiam gradualmente perder sua relevância.

A primeira geração foi marcada pelas influências de Kuhn e Lakatos com as noções de coerência do sistema de conhecimento e de incomensurabilidade formada em rupturas. Mas a, chamemos, segunda geração, da Mudança Conceitual fora marcado pela influência dessas ideias de Toulmin. Essa versão reconsiderada é vista no trabalho de Hunt e Minstrell (1994) que olham para o sistema do conhecimento como sendo composto por elementos dos quais o estudante disponha, chamados facetas. As facetas seriam "[...] uma unidade conveniente de pensamento, um entendimento, um trecho de conhecimento do conteúdo ou uma estratégia utilizada pelo estudante para criar sentido de uma situação particular (HUNT; MINSTRELL, 1994, p. 52, tradução nossa). As facetas, na sugestão dos autores, seriam elementos do sistema de conhecimento que se organizariam estruturando um agrupamento, a partir de domínio específico. Algo que não vemos como diferente de uma rede estruturada a partir da relação entre facetas, orientada por uma demanda intelectual.

Também na vertente toulmiana da Mudança Conceitual, a proposta de DiSessa 
(1993) é vista. O conhecimento em Física se estruturaria como uma rede de unidades, semelhantes às facetas, porém um tanto mais elementares. Essas unidades seriam coletadas pelo aprendiz a partir de sua interação com o mundo físico, atuando como primitivas fenomenológicas (ou p-prims). A partir de demandas específicas, as p-prims seriam ativadas numa ordem de prioridades, permitindo o desenvolvimento de um senso de mecanismo do indivíduo acerca do mundo, construído pelo sistema estruturado com esses p-prims.

Enquanto DiSessa (1993) apresenta a ontologia do sistema complexo do conhecimento, em trabalho posterior (DISESSA; SHERIN, 1998) o funcionamento desse complexo é problematizado. Durante o desenvolvimento conceitual, os indivíduos evoluiriam seus sistemas complexos de maneira semelhante à evolução da ecologia conceitual toulmiana. A mudança, então, dependeria das estratégias de leitura que são utilizadas para extrair informações do mundo físico e da produção de uma rede complexa de inferências, uma rede causal, que relacionaria unidades de modo complexo, produzindo sensos de mecanismo que não podem ser preditos a partir da soma de p-prims, mas sim que emergem das diferentes relações formadas no todo.

Assim, o desenvolvimento não poderia ser linear nem tampouco a ecologia conceitual seria coerente contrastando com a versão kuhniana. Não por acaso, DiSessa (2002) assume explicitamente a aproximação com a proposta de Toulmin e esquematiza o processo de evolução conceitual como ocorrendo numa Ecologia de fragmentos do conhecimento (Fig. 6), sugerindo um sistema complexo que evolui tanto em elementos quanto em relações. $\mathrm{O}$ termo Mudança Conceitual passa a ser traduzido por Evolução Conceitual.

Historicamente, a reconsideração da teoria da Mudança Conceitual é marcada por uma outro trabalho do grupo de Posner (STRIKE; POSNER, 1992) no qual os autores se aproximam da ideia de uma Ecologia Conceitual, incluindo a complexidade evolutiva na base dessa teoria. A complexidade conceitual, conforme tratada nesses trabalhos, tem viés cognitivo e dirigem o interesse para o desenvolvimento das ecologias individuais dos estudantes.

Em trabalho anterior (RODRIGUES; CAMILETTI, 2018) apresentamos evidências 
Figura 6 - Representação esquemática do processo de evolução conceitual, em um sistema complexo composto por fragmentos de conhecimento

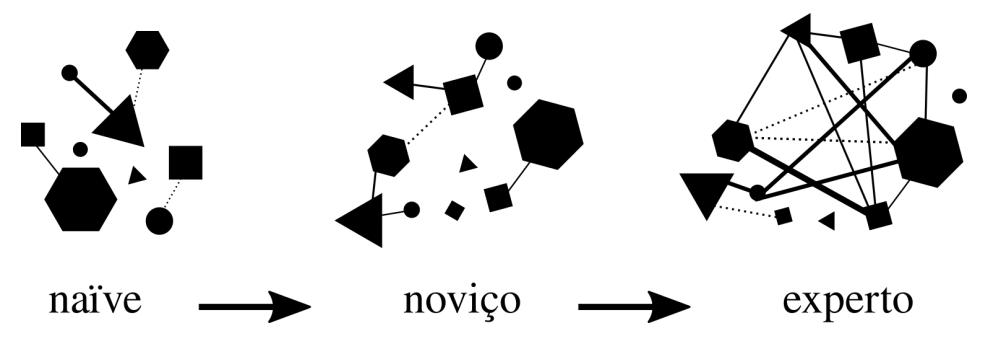

Fonte: elaboração nossa, adaptada de DiSessa (2002).

que são consistentes com a noção de um processo de Evolução Conceitual ocorrendo de maneira incremental. Isso tanto em termos de elementos quanto em termos de relações formadas nas redes complexas de associações entre palavras, produzidas pelos alunos em processo de aprendizagem.

Nossos resultados apontaram para redes semânticas associativas individuais que evoluíam de maneira a complexificar sua estrutura. Naquele trabalho, produzimos análises das estruturas das redes semânticas complexas, na perspectiva da segunda geração da Mudança Conceitual. Confrontamos as variáveis estruturais das redes de palavras formadas pelos estudantes com suas performances em avaliações em testes por medidas psicométricas e com a evolução em seis sensos de auto-eficácia.

Um movimento de análise daquele trabalho que nos fez sair da observação dos indivíduos e ir para as observações do coletivo foi a concatenação das redes representacionais individuais, produzindo uma rede coletiva de associação de palavras. Isso despertou nosso interesse em expandir a fronteira de análise para sairmos das redes representacionais fossem idiossincráticas, ou seja, das ecologias conceituais individuais, para pensarmos redes que se relacionassem a ecologias conceituais do grupo, do coletivo.

Mas neste caso, dois movimentos pareceram necessários: um deles foi sair da noção de aprendizagem, voltada ao indivíduo, e abraçar a noção de representações compartilhadas, que são produtos do grupo social. O outro foi a inclusão de aspectos estritamente sociais, dos quais nos interessam também os complexos interpessoais. Mais ainda, o interesse maior é entender como as ecologias representacionais emergentes nas produções de consensos 
dos alunos estariam ou não relacionadas às ecologias interpessoais emergentes em sala de

aula. É nesse sentido que recorremos às redes para que sejam mais que método, formas de organização do pensamento.

\subsubsection{A rede como artefato e como matriz técnica}

Uma teorização sobre o arquétipo rede é necessária para que não se reduza a força dessa ferramenta intelectual a sua faceta imagética. Não que essa última seja ausente de força. Prova disso é a consolidação do campo de estudos dos mais diversos cenários analisados pelas redes, assim como a construção da presente tese que se lança ao uso das redes também em seu caráter metodológico. Mas que não saia da vista o fato de que as redes são mais que método.

Para Musso (2013), a onipresença - quiçá onipotência - da noção de redes nas diversas disciplinas, sejam ciências naturais, sociais ou em novas tecnologias, indica uma polissemia do vocábulo. Seu sucesso vem dessa polissemia. Mas dela também vem a dúvida sobre o quão coerente seria o conceito rede. A noção de rede, nessa possível incoerência, vive o risco de ser diluída por seu uso excessivo.

No entanto, é também pelo mesmo uso excessivo que a noção de rede tem seu poder confirmado. Se em outras épocas noções como sistema ou estrutura eram bandeiras dominantes, essas etiquetas deram lugar à noção de rede. Por isso, as redes tem caráter duplo: redes são receptoras epistêmicas, pois abarcam formas do pensar; mas redes são também cristalizadoras, pois materializam formas do ser. Musso reconstrói uma linha histórica da evolução da noção força e das mudanças de usos que o conceito estrito de "rede" passou, tal que chegasse a seu status presente.

A rede-renda é o sentido que se dá num momento mais ao início. São sentidos mais próximos à origem etimológica, no latim retiolus, que se refere a tecido, a trama. Têm-se então as redes como referentes à tecelagem, tecido, renda, fios entrelaçados, redes de pesca e de caça. Mas a característica unificadora desses sentidos é que todos eles colocam a rede como um envólucro, que é produzido externo a um corpo, mas tem a função única de envolver, de abraçar o corpo, de cobri-lo. 
A rede-pele se dá num momento mais à frente e se caracteriza pela mudança de empregabilidade do termo. Passa, no Século XVII, a ser utilizada especialmente na medicina como referente a e representante dos tecidos humanos ou sistemas circulatórios. Nesses últimos, são redes de fluxo, como correntezas, internas ao corpo. No sentido de tecidos, são redes de estruturação, num análogo à rede-renda, mas sendo parte do corpo.

O uso do termo reticular para se referir à pele faz migrar o sentido de rede, deixando de ser o objeto entrelaçado no mundo que vem ao corpo e passando a ser também corpo. No caso da rede-pele, a parte do corpo que faz interface com o mundo. Nesse sentido, embora seja já corpo, a rede ainda tem o sentido de envólucro.

Então, a rede-sólido surge com a cristalografia, na qual todo cristal sólido passa a ser visto como um conjunto de poliedros congruentes e justapostos. Isso se dá no início do Século XIX, com estudos da mineralogia. Uma diferença entre este e os modos-rede anteriores é que agora a rede assume a função de ser corpo, internamente. Com isso, ganha um sentido diferente do sentido de envólucro. A rede passa a ser estruturadora do sólido.

Mas a necessidade de teorização desses modos-rede, especialmente o último, aponta o nascimento de uma ciência que buscaria generalizar as redes e suas formas. Com isso ocorre, para Musso, uma grande ruptura, pois as redes deixam de ser observadas dentro do corpo. Saem do mundo natural e passam a ser artificiais. Se transformam em um artefato, em uma técnica autônoma.

Há então uma diferença entre a rede dada e a rede construída. Isso se dá na separação de duas funções potenciais das redes. A primeira (dada) é a rede observada nos corpos, na natureza. A segunda (construída) é a rede como efeito identificável das ocorrências dentro dos corpos ou sobre os corpos. Com isso, o efeito de rede passa a ser uma forma de se pensar relações que não são vistas, estabelecidas entre lugares que são vistos:

A rede é concebida, refletida (pensada) e mesmo formalizada: ela se torna um modelo de racionalidade, representativo de uma ordem formalizável que a teoria matemática cuidará de por em evidência 
A formalização das redes e sua descrição matemática, que Musso aponta terem se iniciado com Descartes e Leibniz, ganham projeção nas representações geométricas dos territórios, dos lugares. Isso é visto em seus usos representativos, como em esboços de reconhecimento militar que formam redes de comunicação, representadas com linhas em forma de redes que, posteriormente, permitem a construção de um mapa.

Formalizar os efeitos-rede marca a mudança da noção de redes como estando no corpo, para redes como artefatos. As redes-artefatos, uma vez formalizadas, passam a ser uma matriz técnica e passam a ser operacionais. Cobrem territórios como as redes de comunicação, ordenam a logística, como as malhas ferroviárias. Uma característica fundamental da formalização do efeito rede é que, por ele, há uma transformação da relação que estabelecemos com o espaço e com o tempo.

\section{Uma definição para rede}

As redes, já como artefatos, podem assumir duas essências. Podem ser tomadas como tecnologias do espírito, sendo tão necessária para se pensar a contemporaneidade quanto fora a noção de árvores à época do Iluminismo. Nesta essência, o conceito de rede cobre como significações nos níveis $(i)$ do seu ser, no qual a rede é uma estrutura de elementos em interação; (ii) da sua dinâmica, na qual a estrutura de interconexões da rede é instável e transiente e ainda (iii) da sua relação com sistemas complexos, na qual a rede passa a ser uma estrutura tácita, mas dotada de uma dinâmica que supostamente explica o que é visível no sistema ao qual se refere.

Na outra essência, como matriz técnica, a rede opera como uma organizadora do espaço-tempo. A restrição espacial é vencida pelo uso da rede. Sendo ela a representante espacial do território, sobrepõe-se enquanto espaço sobre aquilo a que se refere, o território, algo que, para Musso faz com que a rede desterritorialize e reterritorialize. Ainda, a rede permite um rápido intercambio ou transporte de informações ${ }^{5}$. Assim, a rede, como a de comunicação, permite que, ao espaço-tempo físico, sejam adicionados um espaço ampliado

\footnotetext{
${ }^{5}$ basta pensarmos, extrapolando o caso de Musso, com que rapidez uma notícia se espalha num grupo estruturado em rede
} 
e um tempo reduzido. A reorganização do espaço-tempo promovida pelas redes é também uma nova forma de se pensar o vínculo social.

Mas, de maneira semelhante aos alertas feitos pelos pensadores de sistemas e de sistemas complexos que apresentamos anteriormente, Musso indica um posicionamento intermediário, uma vez que a rede é “[...] mais que a máquina, porém menos que o vivente; mais que o linear, porém menos que o hipercomplexo; mais que a árvore, porém menos que a fumaça" (MUSSO, 2013, p. 30).

A definição de Musso então, é de que a rede é “[...] uma estrutura de interconexão instável, composta de elementos em interação, e cuja variabilidade obedece a alguma regra de funcionamento" (MUSSO, 2013, p. 31). E isso é resultado de uma complementação de três níveis de definição: $(i)$ elementos em interação, no sentido de que redes são picos ou nós ligados entre si por caminhos ou conexões, instáveis e definidos em um espaço de três dimensões; (ii) instável no tempo no sentido a estrutura inclui a dinâmica e esta deve considerar (semelhante ao que propõe Capra, mencionado anteriormente) um elemento como rede e como parte de um todo-rede, ou de uma rede em uma rede de redes; e (iii) que a modificação de sua estrutura se dá sob alguma regra de funcionamento, passando-se da dinâmica da rede ao funcionamento do sistema.

\subsubsection{Rede, informação e a amplificação dos mundos}

A migração de uma rede-corpo para uma rede-artefato faz com que as redes passem a ser também o processo de produção de significados, conforme propõem Latour e Hermandt (2013). É numa rede, então, que se constrói a informação. Essa rede não se dá nem no mundo nem nos registros feitos do mundo, mas numa constante circulação de referências entre ambos.

No processo de produção de conhecimento, os registros feitos a partir de cenários ou fenômenos do mundo são transpostos em inscrições. As inscrições se tornam acervos, como os de museus, ou bibliotecas. Mas a informação produzida não está na biblioteca. Nem tampouco no mundo. Paira na ponte feita entre os livros e seus referentes no mundo. 
A produção de informação sobre um fenômeno, então, está numa rede de pontes feitas entre a inscrição e o mundo no qual fenômeno se dá. Essa rede, para os autores, se dá em contraponto ao universo dominante dos signos que tanto confinaria a cultura quanto seria, também, seu instrumento privilegiado de estudo.

Diferente do signo, a informação se configura como uma relação promovida entre dois lugares. Um dos lugares é uma periferia, instância na qual a dinâmica do mundo se dá. O outro lugar é um centro, uma instância na qual os registros que foram selecionados se tornam acervos, coleções de itens, sempre referentes à periferia. A existência da informação, então, se dá por um vínculo que é feito entre centro e periferia, mediante algum veículo. Esse veículo está em circulação entre esses dois lugares.

Com isso, a informação se dá nas idas e vindas pela rede que conecta a inscrição ao mundo. Com isso, as coleções ou as bibliotecas não são repositórios de informação, nem tampouco são ambientes isolados da paisagem natural. São, no entanto, um ponto da rede no qual a ocorrência da circulação permite a produção da informação. A rede não é nem feita de matérias nem feita de signos. Mas é na rede que se dão as circulações que permitem a transformação matéria/signo ou signo/matéria.

A formação de coleções científicas, iniciada possivelmente com os trabalhos de produção de acervos da biodiversidade, feita por naturalistas exploradores, depende de uma série de etapas e processos como a seleção, a escolha, o registro, a identificação, a classificação, a taxonomia, o armazenamento, a representação ou outros. Esses processos permitem a migração da periferia para os ditos centros de cálculo, onde o mundo é trazido à coleção ou o fenômeno é trazido às inscrições do acervo. A existência desses centros de cálculo permite uma solução prática para o problema da polarização presença/ausência nos lugares dos fenômenos, nas periferias.

Então, é nos centros de cálculo que são postas à mesa as pranchas dos naturalistas, seus registros de viagem, suas coleções. Essa é uma fase que, conforme argumentam Latour e Hermandt, funciona esquematicamente como sendo a ponta de um triângulo no qual convergem várias etapas de transformação, que reduzem a periferia a uma referência no centro de cálculo. É nesta fase que uma ponte entre a situação e o texto é produzida. A 
redução se dá mediante uma relação formada entre a expedição e sua transposição em inscrições, ou em registros, ou em imagens.

Figura 7 - Dois momentos produtores de informação nos quais se dão o estabelecimento de relações entre o mundo e as inscrições

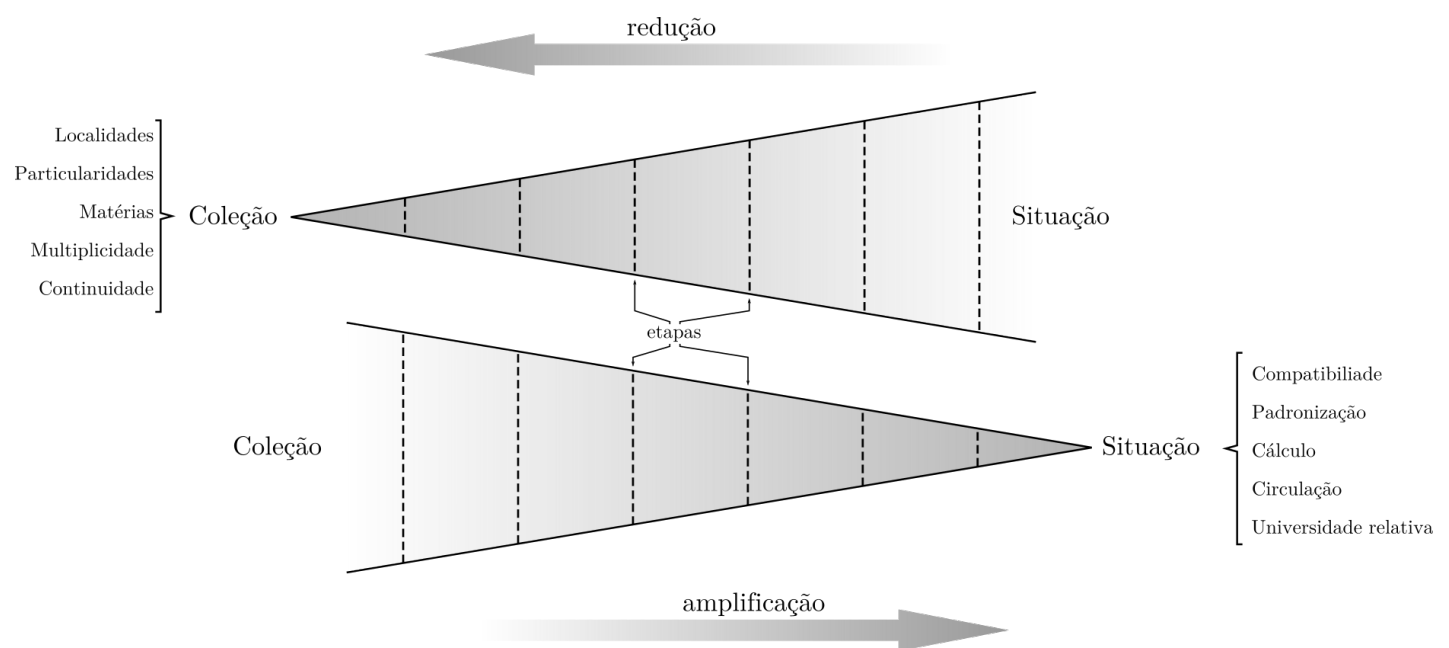

Fonte: elaboração nossa, adaptada de Latour e Hermandt (2013).

Mas, para os autores, esse movimento é seguido de um outro, no qual as coleções servem de processo amplificador da situação. Isso é esquematicamente imaginado como um triângulo oposto, no qual deferentes etapas ocorrem, vindas dos centros de cálculo e convergindo ao mundo, de volta à situação, amplificando-a.

A atuação do especialista então é dupla: a de promover uma redução primeira, que transcreve em registros aquilo que será depositado nos centros de cálculo, aquilo que é escolhido como importante e, por isso, trazido das periferias; mas é também a de produção de reinterpretações e sistematizações que permitem a amplificação do espaço daquela periferia. A periferia é amplificada pela circulação na rede, na informação produzida que habilita modos de interpretação da situação que jamais poderiam ser feitos sem que as fases anteriores fossem concluídas.

Conforme exemplificam Latour e Hermandt, uma coleção de aves taxidermizadas, em um museu de história natural, passa por essas duas fases. Primeiro, a seleção de quais espécimes, quais desenhos, quais descrições devem ser levadas aos centros de cálculo. Nesse 
primeiro movimento, a ave é reduzida a suas inscrições referentes. Suas inscrições se tornam coleção.

Então, num segundo momento se dá a amplificação. Iniciada na coleção, a amplificaçaõ transforma o espaço/tempo da periferia. É na coleção que se pode observar uma sorte de aves do mundo "sinoticamente e sincronicamente reunidas" - nas palavras dos autores.

Com isso, tem-se uma vantagem das inscrições e coleções em relação à observação naturalística in loco. Uma observação direta daria acesso a apenas algumas aves vivas, em momentos específicos. Então, embora a coleção seja menos que a ave, é a coleção que permite o entendimento amplificado sobre a forma de existência de uma classe das aves, na periferia. A sistematização amplificadora dá ao pesquisador um retorno amplificado que faz valer a pena ter primeiramente reduzido a ave às inscrições

O poder de amplificação que a geração de registros e acervos oferece, e suas vantagens de sistematização em relação às observações naturalísticas, coloca as redes em oposição à forma dominante de estudo das culturas, feita pelos signos. E isso se dá em duas linhas: $(i)$ a construção das relações signo/matéria, uma vez que é feita por uma rede de ligações entre as inscrições e o mundo, ou seja, nas conexões entre os centro de cálculos e as periferias, materializa a informação; e (ii) pensando o significado como um resultado das circulações, das idas e vindas nessas redes-ponte com o mundo, as possibilidades de auto-referência e de auto-evidência dos signos são negadas, pois os signos não existiriam em si, mas apenas em circulação nessas redes.

Portanto, livros, registros, coleções e acervos estão conectados com o mundo. Seus significados só se dão quando a informação circula na rede. Isso materializa a informação porque, nessa conéctica, os livros e signos agem sobre o mundo. Por isso, pensar a produção de informação pelas redes não aponta, em nenhum senso, para as formas ingênuas de realismo, como as mera semelhanças. Ao mesmo tempo, as características da redes produtoras da informação na circulação, promove um afastamento do dito "império da semiótica". Podemos, então, pensar uma relação entre as duas linhas do argumento acima e as pontes mútuas entre parte/todo, que aqui são traduzidas como relações rede- 
isso/rede-aquilo. Os signos estão nos fluxos da rede e sua materialização se torna factual quando a rede age no mundo, ou no contrário.

Consideremos dois exemplos: em um, dados de biodiversidade, produzidos a partir de coleções, nos bastidores de um museu de história natural, geram informações que se transformam em ações políticas e estas culminam por preservar um bioma, agindo sobre ele; em outro, uma técnica cirúrgica desenvolvida numa cooperação entre cientistas, vivendo em diferentes partes do globo, resulta em uma nova forma de realização de um procedimento que é, posteriormente, trazida a uma mesa de cirurgia e, com isso, modifica o sistema circulatório de um paciente. Nesses dois exemplos, a rede-informação age na rede-mundo

Podemos ir além e considerar que o processo também ocorre em sentido inverso. Pensemos a reorganização de um governo, vindo a promover um massivo investimento para estudos de um certo bioma, algo que levaria os especialistas a conseguirem produzir novas reduções significantes em seus laboratórios e a terem novas inscrições, novas coleções, novos acervos. Mas isso se segue com a segunda fase, na qual as inscrições levariam a amplificações e a visões jamais tidas sobre o tal bioma. Assim, a rede-mundo estaria também agindo na rede-informação.

E mais, não se pode desconsiderar que os dois sentidos factíveis acima ocorrem contínua e simultaneamente, indo e voltando, circulando entre inscrição e mundo. Mas há que se notar que, em nenhum dos dois sentidos têm-se o processo das redes agindo no mundo ou do contrário, se dando pela observação direta do fenômeno cuja dinâmica se dá na periferia, seja ela o bioma, a cirurgia ou a política. O sentido, mais uma vez, não está no mundo nem está nos centros de cálculo. Ele é fluxo. Ele é a materialização do signo e a significação da matéria. É movimento entre a situação e a inscrição.

As interligações situação/inscrição, ou seja, periferia/centro, promovem também as cartografias. Na cartografia, o mundo é reduzido e amplificado. Como destacam Latour e Hermandt (2013), na cartografia o Atlas deixa de ser o gigante carregando o mundo nos ombros, para ser o atlas-livro, reduzido do mundo. Mas ao mesmo tempo amplificando o mundo de maneira tal que passa a ser carregado nas mãos. 
Toda ciência, como indicam, em algum momento acaba por expor os seus fenômenos de interesse em uma mesa, numa forma reduzida. E esses fenômenos são amplificados quando sobre essas inscrições à mesa reúnem-se os pesquisadores, discutindo, abstraindo, apontando os traços inscritos do fenômeno. Para Latour e Hermandt, é esse o movimento que promove o controle intelectual e o domínio erudito do fenômeno e não alguma operação que se dê diretamente sobre o fenômeno.

A validação do domínio erudito, do controle intelectual sobre o fenômeno, ocorre pela circulação constante nas pontes inscrição/mundo. É isso que permite tornar confiável a relação entre representado e representante. Mas não somente. Há um outro aspecto adicionado pelos autores: a capitalização.

À medida que as inscrições vão se tornando coerentes com o fenômeno e que começam a compartilhar algumas de suas propriedades, ocorre uma capitalização. Isso, no sentido de que ganham valor (conhecimento) e, analogamente ao capital financeiro, também no sentido de que esse valor é difícil de ser medido objetivamente. A agregação de valor seja no capital seja na ciência, vem de toda a rede e, embora tenha origem robusta ${ }^{6}$, sua existência não pode ser negada.

É o acesso às inscrições e o processo de circulação pela rede que habilitam seus "capitalizadores". Isso porque os pesquisadores em seus centros de cálculo estão numa posição de vantagem. Estão apartados dos lugares do mundo. Mas estão, ao mesmo tempo, conectados aos fenômenos.

Dos centros de cálculo, os pesquisadores podem acessar as etapas de transformação mundo/inscrição. Por serem etapas reversíveis, podem ir, o quanto queiram, do fenômeno à inscrição e vice versa. Mais ainda, os centros de cálculo, sendo como coleções, permitem o acesso a quaisquer outras inscrições e, lançando mão delas como apoio, podem impregnar de valor as suas circulações, o que amplifica mais ainda o mundo.

Há um movimento claro, mesmo declarado, de Latour e Hermandt, no sentido de tornarem legítimas e válidas as formas outras da produção do saber que não aquelas

\footnotetext{
${ }^{6}$ no sentido de uma ordem distribuída pela rede, conforme em Ladyman, Lambert e Wiesner (2013)
} 
ligadas ao signo, propriamente dito. Se o sentido é produzido nas circulações entre mundo e inscrição, diferentes instrumentos e seus diferentes usos são necessários para que a rede funcione.

Os autores não mencionam explicitamente a complexidade. Mas o argumento deles e a defesa de formas de produção de significado, em tudo nos remete aos sistemas nos quais a complexidade é inerente. E isso se reflete em sua defesa pela pluralidade instrumental. Para eles, caso um observador ou um instrumento se torne muito específico, seus resultados se tornam muito idiossincráticos. E isso injeta ruído, impedindo a circulação na rede.

Com isso, a produção do significados pelas circulações nas redes, permite um posicionamento epistemológico que não é dependente da observação naturalística na pesquisa e nem tampouco dos encadeamentos discursivos, captados diretamente do mundo:

A veracidade não vem da superposição de um enunciado e de um estado do mundo, mas procede antes da manutenção contínua das redes, dos centros e dos móveis imutáveis que ai circulam. A palavra verdade não ressoa quando uma frase se prende a uma coisa como um vagão a outro vagão, conforme o modelo comum da "adequatio rei et intellectus". Devese ouvi-la antes como o ronronar de uma rede que gira e que se estende. [...] as instituições como bibliotecas, laboratórios, as coleções, não são simplesmente meios que se poderiam dispensar, sob pretexto de que os fenômenos falariam por si mesmos à simples luz da razão. Adicionados uns aos outros, eles compõem os fenômenos que só têm existência por esta exposição através das séries de transformações. No entanto, tal visão, que parece muito afastada do realismo à moda antiga, não nos leva de volta ao simples jogo dos signos

(LATOUR; HERMANDT, 2013, p. 59)

Nesta tese, aderente à proposta acima, as redes da sala de aula são pensadas como sendo, ao mesmo tempo, as inscrições referentes ao agrupamento dos alunos e as circulações pelas quais o movimento entre a periferia e o centro de cálculo habilita a produção de sentidos. Então, os sentidos da sala de aula, nesta tese, não estão nem nos grafos de representação em si nem na própria sala de aula. Além de não serem nunca auto-evidentes. Os sentidos da sala de aula se dão na redução às redes e no retorno ao mundo. Assim a circulação numa rede-sentido estabelece relações entre as redes-inscrições referentes à sala de aula e o mundo, por sua vez também rede, daquela sala de aula. 
As redes da sala de aula, uma vez transformadas em figuras explícitas, imagéticas, são inscrições analisadas única e exclusivamente em sua relação com as realidades construídas naquele mundo microssocial. São redes como matrizes técnicas, como artefatos. Seus significados só são possíveis quando a redução/amplificação circula por uma rede de pontes com o mundo que elas, as próprias redes, cartografam. São ferramentas de transformação que nos permitem escapar à semiótica e ainda assim produzir saberes sobre o mundo da sala de aula. Algo que o posicionamento de Latour e Hermandt, acima, ilumina e legitima.

De forma semelhante à nossa, outras formas do saber são produzidos com a circulação da informação entre a inscrição, nos centros de cálculo, e o mundo. Saberes que se constroem sem a intenção de que a realidade seja algo a ser desvelado pela exaustiva observação direta. Nas diversas ciências se identificam as inscrições, os debates sobre elas nos centros de cálculo e a constante circulação nas pontes que conectam as inscrições ao mundo e o mundo às inscrições.

Podemos pensar nos astrônomos, debruçados sobre desenhos de trajetórias e tabelas de dados astronômicos para discutir posições de um cometa; também biólogos olhando uma figura impressa em um papel, na qual se representam filogenias, e discutindo relações entre espécies. Os primeiros amplificam o cosmos: os sentidos não se constroem nem no desenho da trajetória sobre a mesa nem tampouco no astro, onde jamais pisaram, mas sim no processo de reduzir o cosmos ao papel para, posteriormente, olhar o cosmos de maneira amplificada; os últimos amplificam o ecossistema: os processos evolutivos não estão nem nas filogenias impressas no papel e nem poderão jamais ser notados pela observação direta do ecossistema.

Esses dois exemplos se remetem a dois sistemas inerentemente complexos: o cosmos e os ecossistemas. E, como em quaisquer outras abordagens para sistemas complexos, os sentidos acerca da trajetória de um cometa ou acerca de processos evolutivos não estão nem nas inscrições nem no mundo. Estão, sim, na ida e vinda entre a trajetória do cometa e o telescópio ou entre as constantes idas e vindas entre a filogenia e o ecossistema.

Nessa forma de produção de saberes, a ciência se debruça sobre as inscrições. Partindo delas, amplifica o mundo no indo e vindo entre ele e suas inscrições. Na circulação 
contínua pelas redes de transformação, estejam as inscrições nos cadernos de laboratórios, nas coleções de museus, nas bibliotecas ou, no nosso caso, nos grafos de relações complexas, os sentidos são formados no processo de ligação entre inscrições e fenômeno e não nas inscrições ou nos fenômenos.

É nesse processo de circulação nas redes e de produção de sentidos que, para Latour e Hermandt, a ciência se constrói como tal. É nele que encontramos apoio para nossa iniciativa de pensar e olhar a sala de aula não pelos signos ou enunciados, mas pelas redes emergentes desse "sistema-sala de aula". Nisso, tomamos as redes como método/artefato, mas também como perspectiva teórica, algo que que Musso (2013) chamaria de redes como tecnologia do espírito.

Reduzimos, em nossa contemplação e em nossa ação de pesquisa, a sala de aula a redes para que ganhemos uma amplificação daquele mundo, não apenas pela relação entre as redes-dados e a própria sala de aula, mas porque as redes subsidiam novas formas de se conceber o locus de ensino.

Os movimentos de redução e amplificação dos mundos e de produção de sentidos pelas redes, valendo-se delas também como método, é um movimento que não é somente nosso. A força das redes como matriz técnica associada às redes como perspectiva teórica pode ser vista na variedade de seus usos, sempre remetidos a sistemas e a cenários que tenham a complexidade como essência, como mostraremos a seguir. Embora tenhamos apresentado anteriormente, nesta tese, um caso exemplar de metapesquisa cienciométrica, pontuaremos outros exemplo.

No trabalho de Perino et al. (2019), as redes como conceito são utilizadas na perspectiva da teoria dos sistemas complexos e da complexidade socio-ecológica para o entendimento dos papéis de três elementos interconectados e retroalimentadores: a complexidade trófica, ou seja, dos processos alimentares das espécies; as perturbações estocásticas, que ocorrem a depender do arranjo do sistema; e a dispersão das espécies no ecossistema.

O entendimento habilitado pelas redes naquele trabalho indica caminhos para rees- 
tabelecimento da vida selvagem em diferentes locais do mundo. Algo que, num pensamento linearizador, não se poderia ver.

Também Alves et al. (2019) utilizam as redes como teoria e como método. Produzem redes de comércio entre países a partir de diferentes produtos, nas quais cada produto é considerado uma camada de rede. Então, propõem a sobreposição dessas camadas para construírem uma rede multi-camada que identifica o sistema global de mercado e os nichos de produtos por países.

Além disso, os autores (ibid.) constroem um grafo sobreposto ao mapa-mundi, sugerindo uma rede na qual os países são pontos (ou vértices) e as relações de comércio são conexões (ou arestas), representando uma inscrição explícita das trocas de mercadorias e valores em escala global.

Em um trabalho ambicioso, Gao, Barzel e Barabási (2016) propõem uma função matemática para explicar um padrão universal de resiliência nas redes complexas. Isso significa que em um sistema complexo, há um padrão detectável que pode indicar o quanto o sistema pode ter seus elementos retirados sem que entre em colapso ou, o quanto o sistema pode ter suas relações retiradas sem colapsar.

Isso desperta interesse em múltiplas áreas, pois auxilia a responder questões do tipo "até que ponto as espécies (vértices) podem entrar em extinção antes de um ecossistema ruir?" ou "quantas linhas de transmissão de energia elétrica (arestas) precisam ser desligadas para que um apagão aconteça?". Essas possibilidades indicam uma potência nas redes, seja como tecnologia do espírito seja como matriz técnica.

Numa outra forma de se olhar um arranjo complexo pelas redes, Christakis e Fowler (2007) se valem das redes de associações interpessoais para estudar um modelo de ocorrência de obesidade. Eles tratam a obesidade como um problema de saúde pública e avaliam pelas redes como cada indivíduo tem maior ou menor propensão a ser obeso, de acordo com a estrutura complexa de relações sociais no qual está imerso.

Nessa empreitada de se trazer o pensamento das redes para a pesquisa em medicina e saúde pública, Christakis e Fowler mostram que a obesidade se alastra num padrão de 
rede e que a forma de alastramento depende da natureza da relação interpessoal. Com isso, mais que uma relação causa-efeito obtida apenas das atitudes individuais, a obesidade pôde passar a ser vista como um processo dependente da dimensão social.

Por exemplo, os resultados apresentados pelos autores (ibid.), não mostram maior propensão de ocorrência da obesidade em função da proximidade geográfica com outros obesos. No entanto, uma maior proximidade social indicou maior propensão de ocorrência de obesidade. Nisso, oferecem um novo olhar sobre o problema, quando tratam a ocorrência da obesidade como dependente de um sistema social complexo.

Além do estudo contemporâneo que já apresentamos, a metapesquisa cienciométrica pela ciência das redes fora explorada anteriormente por Barabási et al. (2002) que estudaram como as redes de colaboração científica evoluiriam. Construindo um modelo no qual cada autor é um vértice e cada co-autoria configura uma aresta entre dois autores, uma rede de relações sociais acadêmicas é estabelecida. Quase duas décadas depois, o emblemático trabalho de Gates et al. (2019), ao qual nos referimos no Capítulo 2, viria estampar a capa comemorativa de um dos principais veículos de publicação científica do mundo.

Exemplos como esses apresentados, mostram o quanto as redes são viáveis para produção de saber, operando em um número inimaginável de cenários possíveis. Em nosso trabalho de aproximação da dimensão social e da dimensão socio-representacional da sala de aula, as redes de ideias e as redes de alunos parecem uma perspectiva adequada e frutífera como inscrição, informação, teoria e método de entendimento da complexidade da sala de aula.

Um arcabouço de noções e conceitos das redes nos serve, então, para a investigação da sala de aula. Mas anterior a isso, faz-se necessário traçar um panorama da presença e dos tipos de usos dessa perspectiva para a sala de aula. A dita Ciência das Redes se torna nosso gancho para uma revisão sistematizada da bibliografia global no que tange a pesquisa em educação científica, conforme mostraremos a seguir. 


\subsection{Formalizando redes: noções elementares da Teoria dos Grafos}

\subsubsection{Gênese da Teoria dos Grafos}

A Teoria dos Grafos é o campo de estudos no qual se formalizam e se representam conjuntos discretos que são do tipo elementos/relações. Trata-se de um campo da matemática, chamado Topologia, no qual estruturas relacionais são avaliadas a partir de suas representações matriciais, algébricas ou gráficas. Embora a Topologia, enquanto disciplina, tenha menos de um século de história (SHIELDS, 2012), a utilização de alguma formalização matemática, muito próxima do que hoje se reconhece como "grafos", utilizada no sentido de solucionar problemas relacionais complexos, é documentada como sendo inicialmente proposta pelo matemático Leonhard Euler (GRIBKOVSKAIA; HALSKAU; LAPORTE, 2007).

O problema clássico de Euler, situação quase canônica para introdução da Teoria dos Grafos, é o caso das sete pontes de Köningsberg ${ }^{7}$. Na cidade de Köningsberg, sete pontes sobre o rio Prególia $(a, b, \ldots, g)$ conectavam quatro diferentes regiões da cidade ( $A, B, C$ e $D)$, conforme mostrado na Figura 8, (à esquerda).

Figura 8 - Representação esquemática das sete pontes de Köningsberg. À esquerda, o original de Euler. Ao centro, uma geometria das posições. À direita, o grafo representacional do problema
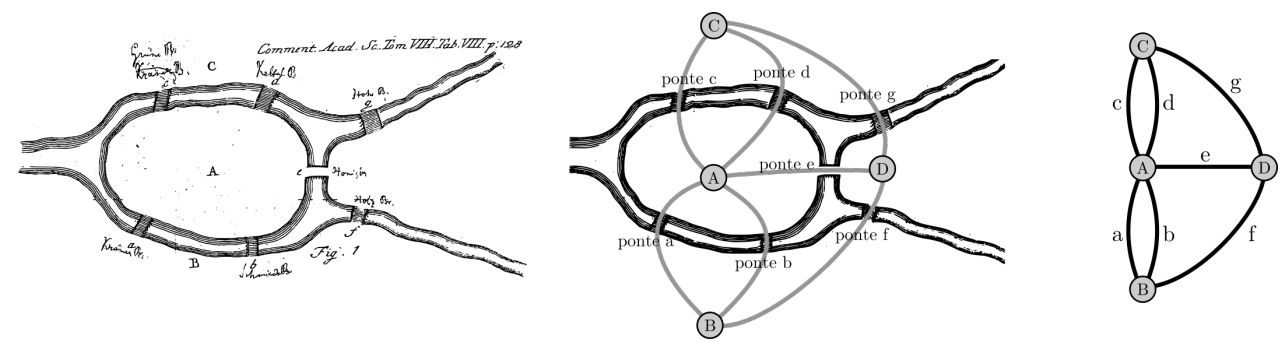

Fonte: elaboração nossa, adaptado de Euler (1741).

O problema consistia em verificar se seria ou não possível uma pessoa passear pela cidade, passando cada uma das sete pontes uma única vez. Conforme ressalta Shields

$\overline{7 \text { antigo território da Prússia, hoje, cidade }}$ de Kalingrado, na Rússia 
(2012), o problema endereçado a Euler inaugurava uma nova forma de lidar com situações. Barabási (2016) reforça que poucos são os campos de pesquisa que têm seu nascimento claramente marcados no espaço e no tempo, mas que no caso da Teoria dos Grafos, as raízes são localizadas nos idos de 1735, na então capital da Prússia oriental, que era uma cidade mercantil fervilhante. A natureza relacional das regiões era o foco. Como característica marcante, nesse problema, a solução dependia de uma análise de conectividade entre as regiões. Era independente do comprimento das pontes. Também independente da distância entre as pontes.

Essa classe nova de problemas, embora pudesse ser tratada algebricamente, não dependia da magnitude, informação central na álgebra. Embora pudesse ser tratada de forma geométrica, não dependia de medições de distâncias. O problema da conectividade lida com uma "geometria da posição", uma tipo de análise na qual interessa apenas a posição e a relação com demais posições. Uma representação imprecisa da cidade, como na Figura 8 (esq.) é suficiente para lidar com a situação. Mesmo uma reconstrução do cenário, com círculos referentes aos locais e linhas referentes às pontes (Fig. 8, à direita) são suficientes para a análise do problema. Euler (1741) mostrou ser impossível seguir o passeio cruzando cada ponte uma única vez e estendeu a solução, mostrando ser impossível tal passeio para qualquer conjunto maior que duas localidades, conectados por um número ímpar de relações.

\subsubsection{Diferentes representações para os grafos}

A representação abstrata, seja ela matricial, algébrica ou imagética, referente à geometria da posição, em qualquer conjunto de elementos e relações é o que hoje se pode chamar de Grafo. Podemos considerar uma região hipotética, composta por oito cidades $(a, b, \ldots, h)$ e podemos estabelecer que há uma relação entre duas cidades, sempre que são adjacentes (vizinhas), conforme o mapa da Figura 9. 
Figura 9 - Representação hipotética do mapa de uma região, com a indicação das localidades-sede e suas fronteiras

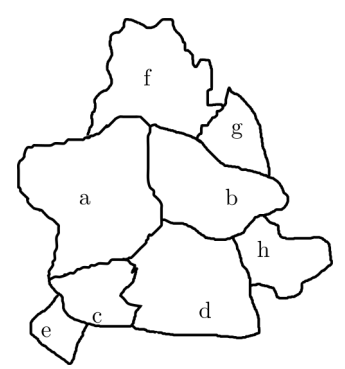

Fonte: elaboração nossa.

Então, para essa região, é possível fazer uma transformação, de modo a se avaliar apenas a topologia das cidades e seus aspectos relacionais, isto é, uma geometria da posição das cidades. Independente do tamanho da cidade ou da distância entre elas, a região passará a ser representada, tomando-se como conectadas aquelas que são relacionadas umas às outras por suas fronteiras. Como resultado, tem-se um grafo que representa a topologia da região. Faz-se, então, uma indicação simples de pontos representando cidades e traços representando adjacências, conforme o passo a passo mostrado na Figura 10.

Figura 10 - Processo de representação das cidades vizinhas por uma rede de adjacências: mais à esquerda o mapa da região e mais à direita o grafo das relações de vizinhança

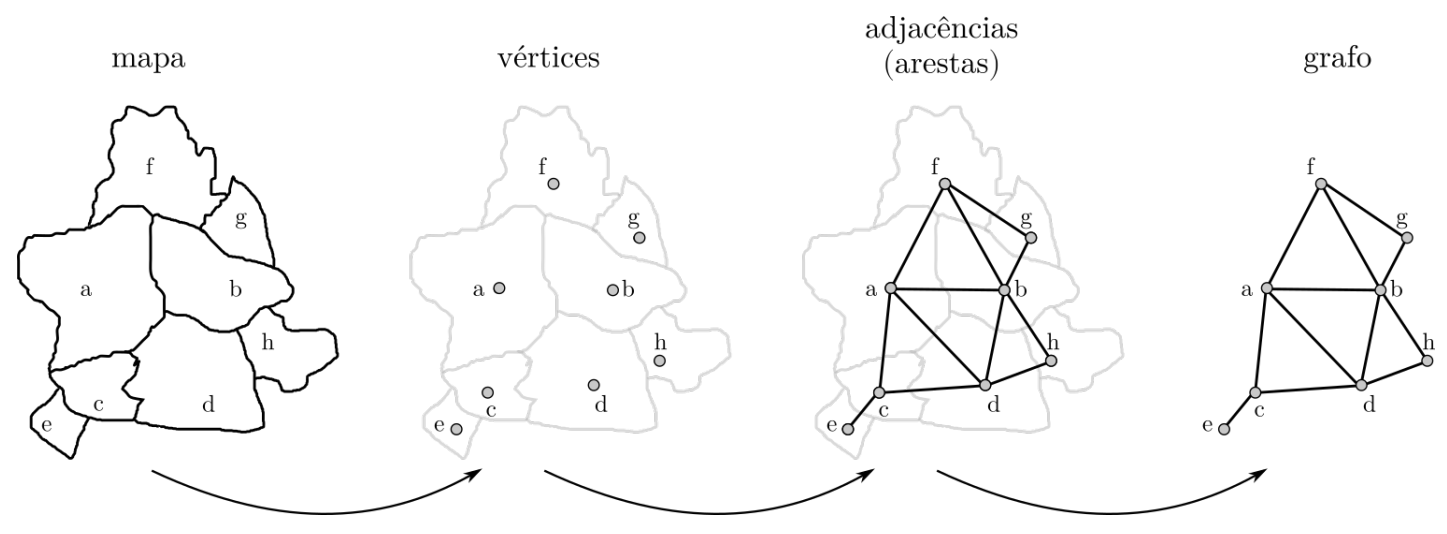

Fonte: elaboração nossa.

Para um grafo, termos específicos são destinados a algumas entidades. Olhemos o grafo da Figura 10 (à direita). Nele, cada um dos pontos que representa cidades passa a 
ser chamado de vértice do grafo, indicando um nó da rede, ou indicando um elemento do sistema. Os traços que ligam localidades passa a ser chamado de aresta do grafo, indicando um link na rede ou uma relação entre elementos do sistema, algo que representa uma adjacência (BARABÁSI, 2016).

Se, de um lado, há importância em se estabelecer um acordo semântico sobre o léxico das redes (dos grafos), como apresentado acima, de outro, os meios para representação do grafo variam, reforçando a produção de sentidos sobre a estrutural relacional do sistema complexo a que a rede se refere. Ainda na mesma região da Figura 10, é possível escrever o conjunto das arestas $(A)$, como uma sequência de pares - não ordenados - de vértices:

$$
A=\{(a, b),(a, c),(a, d),(a, f),(b, d),(b, f),(b, g),(b, h),(c, d),(c, e),(d, h),(f, g)\}
$$

Nessa forma algébrica de representação de um grafo, tem-se o par $(a, b)$ como uma aresta que conecta os vértices $a$ e $b$. Assim, dois vértices são ditos adjacentes sempre que forem conectados por uma aresta. Por outro lado, uma aresta é dita incidente quando se conecta a dois vértices: a aresta $(a, b)$ incide nos vértices $a$ e $b$.

A terceira forma de representar um grafo que será utilizada neste trabalho é a utilização de uma matriz de adjacências. Uma matriz de adjacências, em sua forma mais simples, é uma matriz quadrada, com linhas e colunas correspondendo, ambas, aos vértices do grafo. Em seu caso mais simples, reconhece-se um grafo não direcionado pelo fato de sua matriz de adjacências ser simétrica. Isto significa dizer que uma conexão entre a aresta $a$ e $b$ representa uma conexão também entre $b$ e $a$.

Conforme apresentado por Barabási (2016), a formalização de uma matriz de adjacências pode ser feita considerando-se uma matriz do tipo $A_{i j}$ na qual

$A_{i j}=1$ quando o vértice da posição $i$ está conectado ao vértice da posição $j$.

$A_{i j}=0$ quando os vértices das posições $i$ e $j$ não estão conectados. 
Figura 11 - Exemplo de um grafo com quatro vértices e duas arestas (esq.). Ao centro, a escrita algébrica do grafo, como conjunto de pares. À direita a representação matricial do grafo, com a matriz binária de adjacências

\section{Grafo}

\begin{tabular}{|c|c|c|}
\hline Imagético & Algébrico & Matricial \\
\hline & $\begin{array}{c}\text { Vértices } \\
V=\{a, b, c, d\}\end{array}$ & $\begin{array}{l}\text { (matriz de } \\
\text { adjacências) }\end{array}$ \\
\hline $\mathrm{c}_{\mathrm{g}}$ & $\begin{array}{c}\text { Arestas } \\
E=\{a b, a c\}\end{array}$ & $\mathrm{a}\left[\begin{array}{llll}\mathrm{a} & \mathrm{b} & \mathrm{c} & \mathrm{d} \\
0 & 1 & 1 & 0 \\
1 & 0 & 0 & 0 \\
1 & 0 & 0 & 0 \\
0 & 0 & 0 & 0\end{array}\right]$ \\
\hline
\end{tabular}

Fonte: elaboração nossa.

Em uma matriz de adjacências binária, atribui-se para as posições nas quais os vértices adjacentes se cruzam, o valor 1. Já no cruzamento de dois vértices que não estejam conectados em seus sistema de origem, ou seja, dois vértices não-adjacentes, atribui-se o valor 0, assim como mostrado na Figura 11.

Pode-se então, utilizar essa formalização para retornar ao caso das cidades vizinhas (Fig. 10), e representar as vizinhanças entre cidades por uma matriz de adjacências binária e simétrica, conforme mostramos na Figura 12.

Figura 12 - Rede das cidades vizinhas, representadas pelo grafo, à esquerda e pela matriz de adjacências, à direita
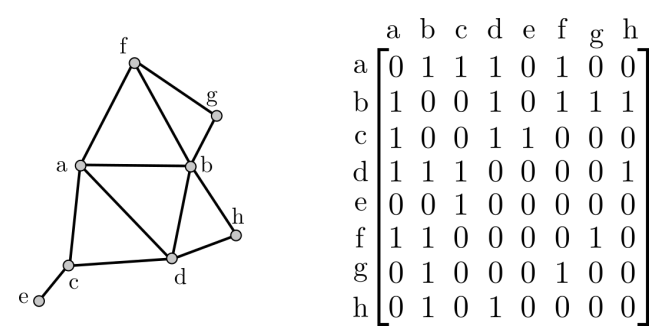

Fonte: elaboração nossa.

Cada forma de representação do grafo pode estar mais adequada a propósitos específicos. A representação imagética oferece um panorama rápido no qual se podem identificar, prontamente, saliências na rede, como um vértice muito mais conectado aos 
demais (e.g. vértice $b$ ) ou outros, excluídos da estrutura (e.g. vértice $e$ ). A representação na forma de conjuntos de vértices e conjunto de arestas é particularmente útil como registro primário e como forma de entrada de informação em softwares dedicados à análise das redes. Já a representação matricial do grafo é útil para que se procedam medições topológicas da estrutura, como as mostradas a seguir.

\subsubsection{Medidas estruturais elementares de um grafo}

\section{Grau do vértice}

Em um sistema complexo, representado por uma rede, ou um grafo, diferentes elementos podem ter diferentes números de conexões a outros elemento. De modo a diferenciar essa característica, chama-se por grau de um vértice o número de arestas que nele incidem.

Quando se trata de um grafo não direcionado (i.e. com a matriz de adjacências simétrica), com arestas sem valores de pesos (i.e. matriz de adjacências binária), o grau de um vértice pode ser obtido a partir da soma de todos os uns de uma linha ou de uma coluna, referente a um vértice $i$ ou $j$ :

$$
k_{i}=\sum_{i=1}^{N} A_{j i} \quad \text { ou } \quad k_{i}=\sum_{j=1}^{N} A_{i j}
$$

Retornando ao grafo que representa as cidades vizinhas (Fig. 13, a seguir). A cidade $e$, por exemplo, se conecta a apenas uma outra. Por isso, é um vértice que tem grau 1. A cidade $b$, por seu turno, se conecta a outras cinco cidades e, então, é um vértice de grau 5.

Uma das vantagens de se representar formalmente um grafo com vértices proporcionais ao seu grau é que discrepâncias são vistas rapidamente. No caso das cidades, com a representação do grafo da Figura 13, um representante do poder público, por exemplo, ao executar planejamento daquela região, poderia facilmente identificar locais mais adequados à construção de um hub (polo) de aviação, como a cidade $b$ por exemplo, enquanto poderia, ao mesmo tempo, identificar as localidades mais isoladas da estrutura (como a cidade $e$ ). 
Figura 13 - Utilização da matriz de adjacência para o cômputo do grau de cada vértice (à esquerda); representação imagética do grafo, com cada vértice tendo tamanho proporcional a seu grau (ao centro) e distribuição dos graus, por conjunto de vértices (à direita)
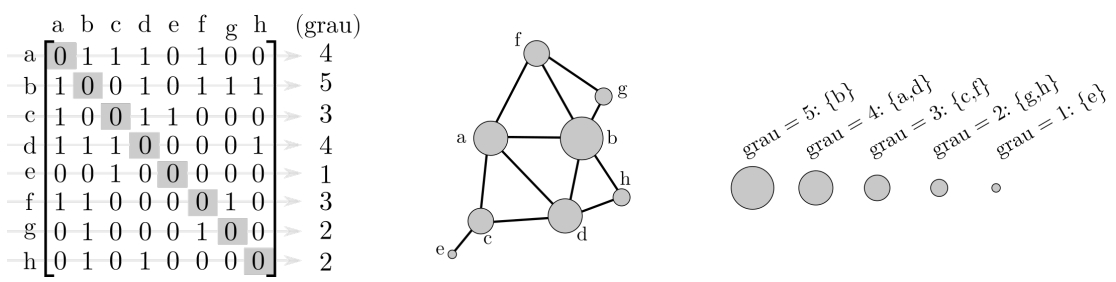

Fonte: elaboração nossa.

Embora tenha caráter descritivo, o valor do grau de um vértice é uma das formas de se pensar a importância daquele elemento em relação ao sistema, a partir de uma representação reticulada.

\section{Grafos direcionados e os graus de entrada e de saída de um vértice}

Alguns grafos podem assumir um caráter direcional (Fig. 14):

Figura 14 - Comparativo entre matrizes de adjacências para os grafos não direcionados e para os grafos direcionados

\section{Matriz de adjacências}

$$
A_{i j}=\left[\begin{array}{cccc}
\mathrm{a} & \mathrm{b} & \mathrm{c} & \mathrm{d} \\
A_{11} & A_{12} & A_{13} & A_{14} \\
A_{21} & A_{22} & A_{23} & A_{24} \\
A_{31} & A_{32} & A_{33} & A_{34} \\
A_{41} & A_{42} & A_{43} & A_{44}
\end{array}\right]
$$

Grafo não direcionado

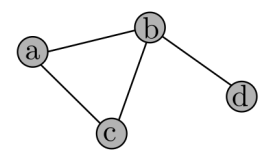

$$
A_{i j}=\stackrel{\mathrm{b}}{\mathrm{b}}\left[\begin{array}{llll}
\mathrm{a} & \mathrm{b} & \mathrm{c} & \mathrm{d} \\
0 & 1 & 1 & 0 \\
1 & 0 & 1 & 1 \\
1 & 1 & 0 & 0 \\
0 & 1 & 0 & 0
\end{array}\right]
$$

Grafo direcionado

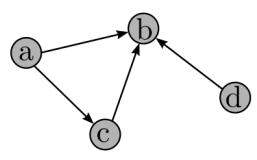

$$
A_{i j}=\left[\begin{array}{cccc}
\mathrm{a} \\
\mathrm{b}
\end{array}\left[\begin{array}{llll}
0 & 0 & 0 & 0 \\
1 & 0 & 1 & 1 \\
1 & 0 & 0 & 0 \\
0 & 0 & 0 & 0
\end{array}\right]\right.
$$

Fonte: elaboração nossa, adaptado de Barabási (2016).

O sistema complexo de fluxo de capital entre países, por exemplo, pode ter uma 
rede cujos vértices se conectam pela saída de capital, mas também pela entrada de valores. Nesse caso, a matriz de adjacências, referente ao sistema, deixa de ser simétrica e a noção de grau de um vértice ganha aspectos de saída ou de entrada, conforme mostrado na Figura 14 .

Outros casos, como fluxo de turistas de entre países, troca de likes entre perfis de redes sociais do cibermundo, fluxos de nutrientes em sistemas metabólicos, dentre outros, são casos nos quais os elementos do sistema podem se conectar a outros pela emissão de uma forma de relação ou pela recepção.

Quando se trata de um grafo direcionado, o grau de entrada é dado pelo somatório de todos os vértices das colunas $j$ que estabelecem uma relação com um certo vértice que compõe a linha $i$ : $k_{i}^{\text {in }}=\sum_{j=1}^{N} A_{i j}$. Já o grau de saída é dado pelo somatório de todos os vértices das linhas $i$ que estejam conectados ao vértice que compõe a coluna $j$ : $k_{j}^{\text {out }}=\sum_{i=1}^{N} A_{j i}$.

Na Figura 15 vê-se, à esquerda, que no caso do grafo não direcionado, uma vez que a matriz de adjacências é simétrica, o grau do vértice $b$ é igual a três, seja medido pela linha, seja medido pela coluna.

Figura 15 - Cômputo do grau de um vértice, para grafos não direcionados (à esquerda) e cômputo dos graus de entrada e de saída para grafos direcionados (à direita)

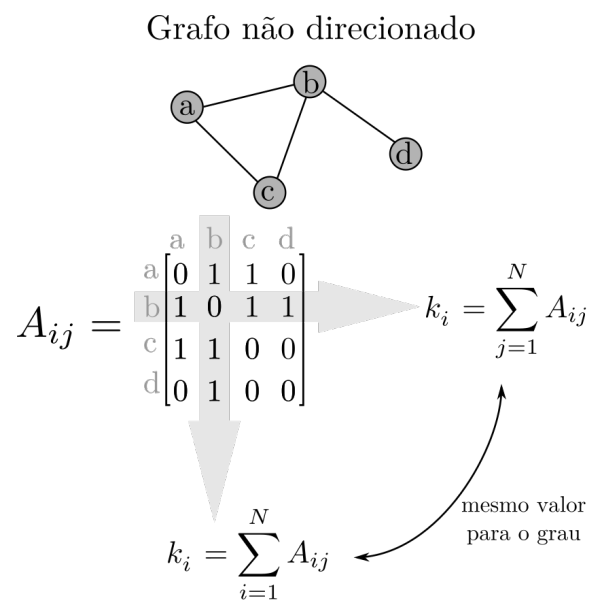

Grafo direcionado
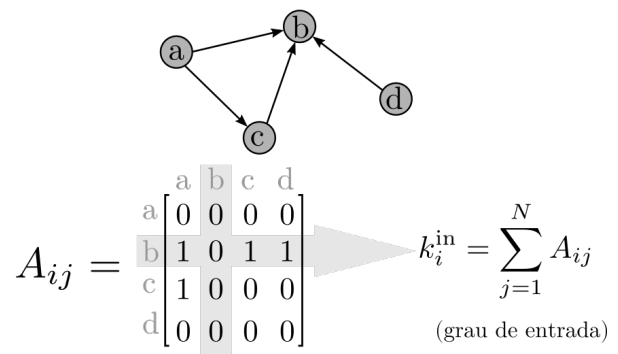

$k_{i}^{\text {out }}=\sum_{i=1}^{N} A_{i j}$

(grau de saída)

Fonte: elaboração nossa. 
No entanto, vê-se, à direita, que o grafo direcionado apresenta para o vértice $b$ um grau de entrada igual a três, medido pela linha $2\left(A_{2 j}\right)$, e um grau de saída igual a zero, medido pela coluna $2\left(A_{i 2}\right)$. É possível também, determinar o grau total de um vértice, pela soma dos graus de entrada e de saída.

\section{Grafos com arestas pesadas}

Outro aspecto que pode ser informado em relação a um grafo é o peso de suas arestas. Um sistema $G$ que tenha quatro vértices $V_{G}=\{a, b, c, d\}$ e que tenham relações não direcionadas. É possível que um sistema desse tipo tenha alguns pares de vértices conectados com relações mais fortes do que outros. Neste caso, as arestas deixam de ser binárias (ou booleanas, com 1 para aresta existentes e 0 para aresta não existente) e passam a ter um valor que designa a intensidade do link entre ambas, chamado de peso da aresta. A matriz de adjacências passa a ter valores numéricos indicativos dos pesos.

Isso é mostrado na Figura 16, com um caso da aresta $E_{G}=\{a, b\}$ com peso $w=3$ a aresta $E_{G}=\{c, d\}$ com peso $w=5$. Assim, os pesos das arestas acrescentam ao grafo a noção de intensidade de uma relação. Com isso, países mais intensamente relacionados podem ser vistos numa rede de comércio; pessoas mais fortemente atadas podem ser identificadas numa rede social; palavras mais semelhantes podem ser vistas numa rede semântica ou órgãos mais interdependentes podem ser avaliados em uma rede metabólica.

Figura 16 - Grafo não direcionado, com arestas pesadas em sua representação imagética (sup.), matricial (inf. à esquerda) e o heatmap referente (inf. à direita)

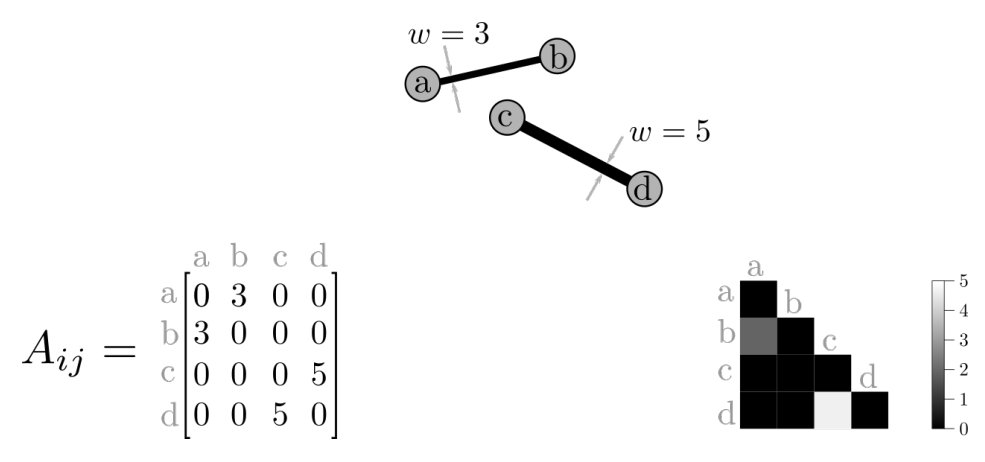

Fonte: elaboração nossa. 
Na Figura 16, mostra-se ainda uma outra forma de representação da rede, que é um misto de uma representação imagética e uma representação matricial. Essa representação (inf. à direita) é chamada heatmap ou mapa de calor, na qual a distribuição de pesos é transformada em um continum de cores, cujo contraste se possa notar visualmente. Isso é feito para que os pesos das arestas sejam convertidos em valores $R G B$ ou outra matriz de cores. Ou mesmo em escala de cinza, como no exemplo. Especialmente em redes com grande números de elementos, a representação da rede na forma de um heatmap oferece uma informação visual rápida, indicando em que região da matriz de adjacências estão as conexões mais fortes.

Dentre inúmeros outros exemplos, os pesos das arestas em um grafo têm a característica de análise voltada a pares, a relações entre dois vértices. Apesar disso, a noção de peso de uma aresta pode ser utilizada em conjunto com a noção de grafos direcionados e, com isso, os vértices podem ter seu grau determinado de outras formas, como o total dos pesos das arestas incidentes, ou o total do peso das arestas incidentes de entrada menos o total dos pesos das arestas incidentes de saída. Como em outras formas de uso da matemática como ferramenta, a decisão de análise depende dos sentidos que se produzem sobre o mundo que essa ferramente está modelando.

Embora tenhamos apresentado medições estruturais elementares dos grafos, suficientes para o suporte teórico e metodológico que empregamos nesta tese, há que ressaltar que a Teoria dos Grafos é dotada de uma consistência interna sólida e está em pleno desenvolvimento. Dessa maneira, novas formas de se produzir análises estruturais das redes se sofisticam e acabam por habilitar novos campos de pesquisa tanto interna (dos grafos) quanto externa (usos dos grafos). Dentre esses campos, cabe a menção às análises de centralidade (BORGATTI; EVERETT, 2006), de comunidades (VEGA-PONS; RUIZ-SHULCLOPER, 2011) e de resiliência (GAO; BARZEL; BARABÁSI, 2016) dos grafos. 


\section{Diferentes grafos, diferentes sistemas}

Barabási (2016) reforça que na literatura científica contemporânea, os termos grafo e rede se intercambiam no discurso dominante. Rede e grafo, muitas vezes se referem à mesma forma de modelagem de sistemas complexos. Da mesma forma um nó (da rede) ou um vértice (do grafo) se referem à mesma noção de elemento e também um link (da rede) ou uma aresta (do grafo) se referem à mesma noção relacional.

Outro aspecto destacado por Barabási (2016) é que a utilização da ciência das redes é diversa, tanto em formas quanto em envergadura de trabalhos. O autor apresenta uma breve comparação entre tipos de redes e tipos de sistemas referentes, conforme Tabela 1, adiante.

Vê-se que a escolha de grafos direcionados ou não depende do interesse em se avaliar relações de um para outro elemento ou simplesmente entre elementos. Ainda, a escolha das formas de relação, ou arestas, é feita a partir de características inerentes ao sistema.

Assim, o sentido dos grafos como formalização das redes na pesquisa, não é autoevidente. Da mesma forma que as bordas de um sistema complexo dependem em parte da função desempenhada pelo sistema e em parte da estratégia utilizada para descrevê-lo, conforme frisa Cilliers (2001), também os elementos e as aresta de um grafo têm essa dependência mista: parte da função dos elementos e das relações no sistema, parte da estratégia utilizada para avaliação do sistema.

Tabela 1 - Comparativo de algumas possibilidades do uso das redes para análise de sistemas complexos

\begin{tabular}{lllc}
\hline Tipo de rede & Nó & Link & Direcionado \\
& & & \\
Internet & Roteadores & Conexão & $\times$ \\
www & Páginas & Link & $\checkmark$ \\
Energia Elétrica & Usinas & Cabos & $\times$ \\
Chamadas de celular & Usuários & Chamadas & $\checkmark$ \\
Colaboração científica & Autores & Co-autorias & $\times$ \\
Cênicas & Atores & Contracena com & $\times$ \\
Metabolismo do E. Coli & Metabólitos & Reações químicas & $\checkmark$ \\
Interação proteica & Proteínas & Reação de ligação & $\times$ \\
\hline
\end{tabular}

Fonte: adaptado de Barabási (2016), tradução nossa. 
Isso nos dá algum entendimento sobre o uso da ciência das redes, em sua formalização matemática dos grafos, como abordagem adequada para múltiplas áreas de pesquisa. Virtualmente, sobre qualquer sistema que se valha de uma característica constitutiva (BERTALANFFY, 2010), explicações só poderão ser produzidas se forem considerados os aspectos relacionais do sistema.

Diante dessa pluralidade dos grafos, nos interessa, então, mapear de maneira sistematizada os jeitos como essa proeminente ciência vem sendo utilizada enquanto abordagem de pesquisa em educação em Ciências. Nesse sentido, procedemos, no Capítulo 3 a seguir, um mapeamento sistematizado. Com ele, buscamos construir um panorama do status quo internacional, da utilização das redes e, por consequência, dos grafos, como abordagem de pesquisa. 


\section{Ciência das Redes na Pesquisa em Educa- ção em Ciências}

Nem a salvação nem a perdição residem na técnica. Sempre ambivalentes, as técnicas projetam no mundo material nossas emoções, intenções e projetos. Os instrumentos que construímos nos dão poderes mas, coletivamente responsáveis, a escolha está em nossas mãos.

Pierre Lévy

$\mathrm{F}$

ORMAS inovadoras de produção de conhecimento não se estabelecem prontamente. Dependem de uma trilha histórica para que sejam sedimentadas. Há a necessidade de formação de novas comunidades de pensamento, dentro das quais o conjunto de acordos epistemológicos permite que não se precise revalidar seus fundamentos. Embora a noção de redes surja na aurora do iluminismo (MUSSO, 2013), sua sistematização enquanto ciência formal é mais recente. Mas sua popularização somente ocorre com a facilitação de uso de ferramentas computacionais mais recentes. Mais recente ainda, são as iniciativas de se propor diferentes usos das redes para a pesquisa em educação.

Talvez por isso, a utilização da perspectiva das redes na pesquisa em Educação em Ciências parece ser um terreno fértil. Entretanto, seja pela solidez de outras tradições de pesquisa já estabelecidas, seja pela dificuldade de acesso e operação das ferramentas computacionais necessárias à sua modelagem e análise, a trilha histórica dessa abordagem na pesquisa educacional, pode estar, ainda, em seus estágios iniciais de construção, conforme buscamos mapear no levantamento a seguir. 


\subsection{Levantamento Bibliográfico}

\subsubsection{Base de dados}

No sentido de construir um panorama, procedemos uma revisão sistematizada das publicações acadêmicas globais que aproximem a Ciência das Redes e a Educação Científica. O repositório escolhido foi o Educational Resources Information Center (ERIC) ${ }^{1}$, que é uma base de dados mantida pela agência governamental dos Estados Unidos Institute of Education Sciences (IES, 2020) e que indexa mais de 1.000 revistas científicas de todas as partes ao redor do globo, aglutinando publicações acadêmicas que se relacionam à Educação em algum aspecto.

ERIC é uma biblioteca digital, hoje voltada à internet, mas que desde o ano de 1966 atua como repositório de revistas científicas e outras formas de publicação de pesquisa educacional. Sua escolha como repositório de interesse foi feita tanto pelo tamanho do acervo de revistas indexadas quando pela frequência de acessos, que passa de 500.000 por semana.

Além disso, a comunidade usuária do ERIC têm ampla versatilidade de interesses, e mescla pesquisadores em educação, alunos e professores, dentre outros. Para além da indexação de revistas, o ERIC também dispõe de uma ampla gama de artigos, com mais de 350.000 trabalhos entre textos de revistas com revisão por pares, textos de anais de eventos científicos e livros, colocando a plataforma como ideal para traçarmos um parâmetro global do nosso tema.

\subsubsection{Chave de procura}

Para sistematizar o levantamento, buscamos por artigos publicados em periódicos, selecionando apenas os que tivessem revisão por pares. Utilizamos o termo Network Science como chave de procura.

A busca por artigos publicados, tomando-se um termo-chave como filtro, via

$\overline{1<\text { https://eric.ed.gov/ }>}$ 
de regra acaba por retornar uma grande variedade de trabalhos. Isso carrega ruído na informação desejada, pois todo termo-chave é polissêmico. Em nosso levantamento, a busca por artigos sobre a Network Science retornou mais de 2.500 trabalhos. Desses, 1.824 foram publicados nos últimos 20 anos (Fig. 17, à esquerda). Isso configurou nosso primeiro universo bibliográfico de interesse.

\subsubsection{Filtros}

Estamos interessados em mapear como a ciência das redes é utilizada no cenário global da pesquisa em educação. De modo a afunilar o mar de trabalhos possíveis para nosso tema específico de tese, que é a Ciência das Redes e a análise das redes voltadas à pesquisa em Educação em Ciências, utilizamos uma filtragem pelos descritores oferecidos pela plataforma $E R I C$, sobre o tema.

Como nossa proposta é a utilização das redes tanto como perspectiva teórica unificadora, quanto como método, pois estamos interessados em interpretar a sala de aula no viés da complexidade e ainda analisar as relações complexas emergentes da sala de aula, na forma de redes, elegemos como primeiro filtro o descritor Network Analysis (Fig. 17, ao centro).

A presente tese também consta de um estudo de caso, trabalhada no chão escolar, conforme mostraremos a diante, situado em uma sala de aula de Física. Mesmo assim, a proposta das redes para a sala de aula é elaborada num âmbito um tanto mais amplo, pensando a educação em seu caráter didático e tomando a educação científica como campo de trabalho. Por isso, acrescentamos o descritor Science Education (Fig. 17, à direita) como filtro, de modo a reter não apenas os trabalhos relacionados especificamente à Física, mas outros dentro da educação científica.

\subsubsection{Recorte temporal}

Procedemos então uma métrica temporal, descrita na Figura 17, de modo a observar a evolução do tema, nas publicações encontradas. Foram fracionadas as ocorrências de artigos nos intervalos temporais permitidos na base ERIC. Separamos $(i)$ total de artigos 
nos últimos 20 anos (1999- ); (ii) total de artigos nos últimos 10 anos (2009- ); (iii) total de artigos nos últimos 5 anos (2014- ); e (iv) total de artigos desde o ano anterior (2017 - ) até 2018, ano do levantamento.

\subsubsection{Publicações encontradas}

Para o intervalo definido, após a filtragem pelos dois descritores escolhidos (Fig. 17, à direita), foram retornadas 15 publicações que declaram utilizar a Ciência das Redes e a análise das redes na pesquisa em Educação em Ciências.

Figura 17 - Levantamento de publicações dos últimos 20 anos, feita na base ERIC, acerca de Network Science. Acesso em 22/04/2018
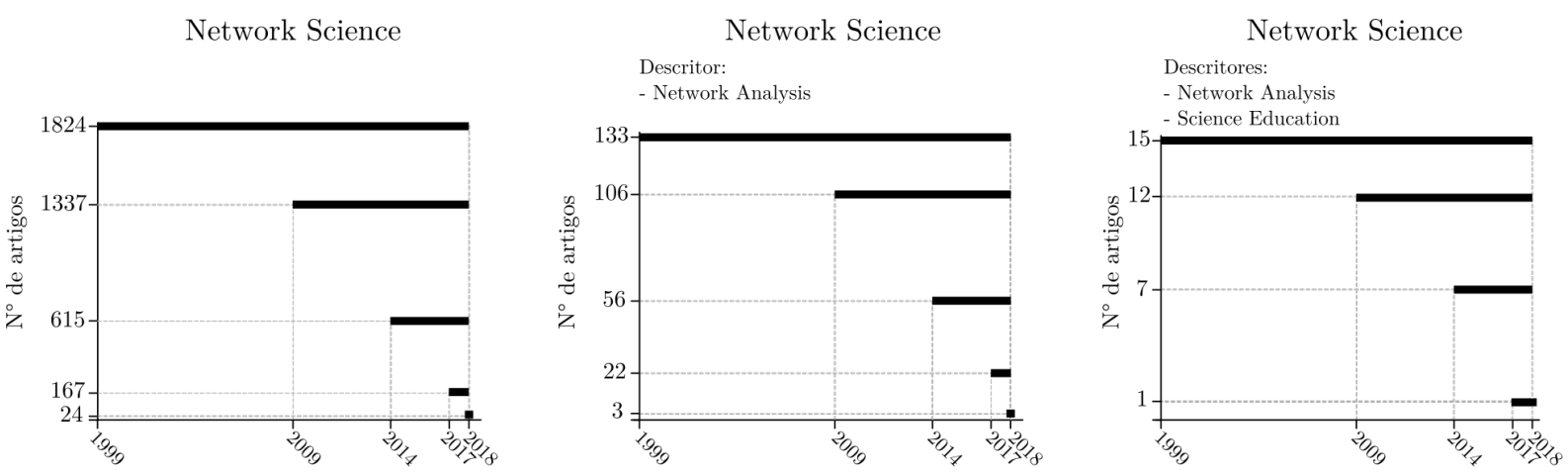

Fonte: elaboração nossa.

O cenário mostra que essa utilização está, via de regra, associada à abordagem de aspectos da complexidade (vide Tabela 2). De tanto, na distribuição de trabalhos retornados, 11 dos 15 artigos abordaram o tema complexidade. Nem sempre um trabalho que se declara como procedendo análise de redes vai se valer das representações imagéticas explícitas das redes (os grafos). Isso se confirma no fato de que, dos 15 trabalhos retornados, nove deles se valem do artefato imagético.

Em relação à distribuição das publicações retornadas, avaliando-se a concentração por revista científica, o panorama levantado mostrou uma concentração saliente em dois periódicos. Uma delas é a Physical Review Physics Education Research (antiga Physical Review Special Topics - Physics Education Research) (Fig. 18, C), publicação da American Physical Society, concentrando três dos 15 trabalhos retornados. A outra é a revista Science 
Education International, publicação da International Council of Associations for Science Education, que concentrou dois dos 15 artigos. Os demais artigos são distribuídos em outras revistas que não se repetem.

Figura 18 - Distribuição dos trabalhos levantados na revisão sistemática, representados por abordagem e por modelagem (A); pelas formas de utilização das redes (B) e a concentração de trabalhos por períódico $(\mathrm{C})$.

(A)

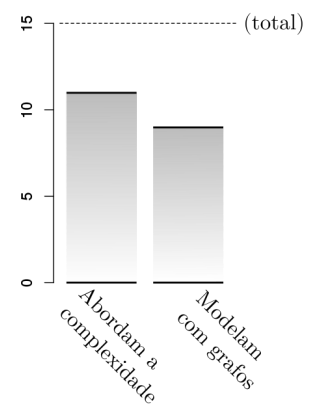

(B)

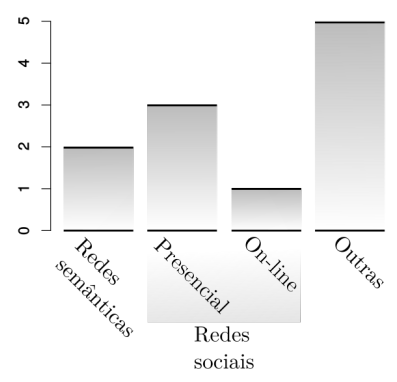

(C)

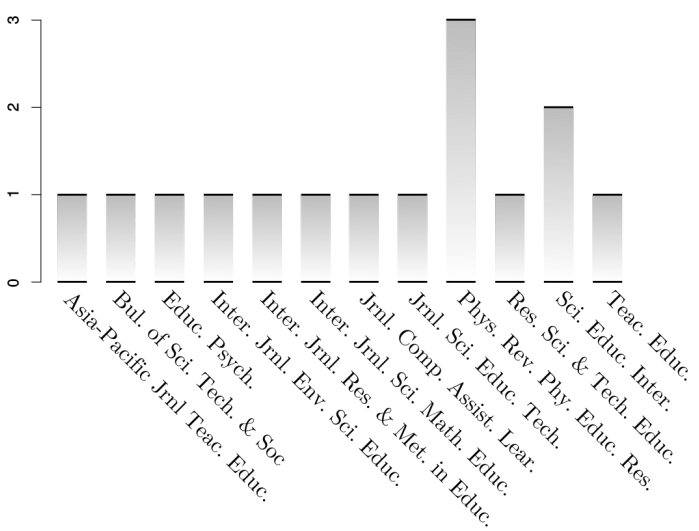

Fonte: elaboração nossa.

A concentração das publicações em algumas revistas científicas é indício de aglomeração de uma comunidade de produção de conhecimento, a partir das redes. Essa comunidade se estabelece também pela aglomeração de publicações por grupo de autores. J. Bruun é o autor com maior número de retornos, figurando autoria de três dos trabalhos, seguido por E. Brewe, K. Tang e C. Tasai que figuram a autoria de dois dos trabalho, com todos os demais autores aparecendo uma única vez nos demais trabalhos retornados. Considerando as colaborações, a díade J. Bruun e E. Brewe são colaboradores em dois trabalhos e a díade K. Tang e C. Tsai em outros dois. Todos os outros pares de co-autoria no levantamento, aparecem uma única vez.

Em relação às formas de utilização das redes, a escolha sobre o quê observar varia. As bases da teoria sistêmica e da teoria das redes consideram sempre os elementos constituintes e suas relações possíveis em um sistema. Esse foi um traço característico de todos os trabalhos retornados. Mas a escolha dos elementos e a escolha das relações se 
apresentou diversa.

Tabela 2 - Sumarização de atributos dos artigos retornados da revisão sistematizada na plataforma ERIC

\begin{tabular}{|c|c|c|c|c|c|c|c|c|}
\hline & \multirow{3}{*}{ Artigo } & \multirow{3}{*}{ Tema } & \multirow{3}{*}{$\begin{array}{l}\text { Aborda } \\
\text { comple- } \\
\text { xidade? }\end{array}$} & \multirow{3}{*}{$\begin{array}{l}\text { Modela } \\
\text { em } \\
\text { grafos? }\end{array}$} & \multicolumn{4}{|c|}{ Redes } \\
\hline & & & & & \multirow[t]{2}{*}{ Semânticas } & \multicolumn{2}{|c|}{ Sociais } & \multirow[t]{2}{*}{ Outras } \\
\hline & & & & & & Presenc. & Online & \\
\hline 01 & $\begin{array}{l}\text { Fehr, Sølberg e } \\
\text { Bruun (2018) }\end{array}$ & $\begin{array}{l}\text { Redes e desenvolvi- } \\
\text { mento no ensino de } \\
\text { Ciências }\end{array}$ & $\checkmark$ & $\checkmark$ & & & & $\checkmark$ \\
\hline 02 & $\begin{array}{l}\text { Tang et al. } \\
(2016)\end{array}$ & $\begin{array}{l}\text { Suporte metacogni- } \\
\text { tivo à aprendizagem } \\
\text { e co-citações }\end{array}$ & $\checkmark$ & $\checkmark$ & & & & $\checkmark$ \\
\hline 03 & $\begin{array}{l}\text { Tang e Tsai } \\
(2016)\end{array}$ & $\begin{array}{l}\text { Suporte metacogni- } \\
\text { tivo à aprendizagem } \\
\text { e co-citações }\end{array}$ & $\checkmark$ & $\checkmark$ & & & & $\checkmark$ \\
\hline 04 & $\begin{array}{l}\text { Brewe, Bruun e } \\
\text { Bearden (2016) }\end{array}$ & $\begin{array}{l}\text { Rede de relações no } \\
\text { conceitos de Força }\end{array}$ & $\checkmark$ & $\checkmark$ & $\checkmark$ & & & \\
\hline 05 & $\begin{array}{l}\text { Ryu e Lom- } \\
\text { bardi (2015) }\end{array}$ & $\begin{array}{ll}\text { Engajamento } & \text { no } \\
\text { aprendizado } & \text { de } \\
\text { Ciências } & \\
\end{array}$ & & $\checkmark$ & & $\checkmark$ & & \\
\hline 06 & $\begin{array}{l}\text { Rauch et al. } \\
(2014)\end{array}$ & $\begin{array}{l}\text { Redes de interação } \\
\text { entre professores e } \\
\text { alunos }\end{array}$ & $\checkmark$ & & & & & \\
\hline 07 & $\begin{array}{l}\text { Forsman, Moll } \\
\text { e Linder (2014) }\end{array}$ & $\begin{array}{l}\text { Inter-relações sociais } \\
\text { e acadêmicas }\end{array}$ & $\checkmark$ & $\checkmark$ & & $\checkmark$ & & \\
\hline 08 & $\begin{array}{l}\text { Schizas, Ka- } \\
\text { trana e Stamou } \\
(2013)\end{array}$ & $\begin{array}{l}\text { Relações semânticas } \\
\text { e aprendizagem con- } \\
\text { ceitual }\end{array}$ & $\checkmark$ & $\checkmark$ & $\checkmark$ & & & \\
\hline 09 & $\begin{array}{l}\text { Bruun e Brewe } \\
(2013)\end{array}$ & $\begin{array}{l}\text { Quantificação de inte- } \\
\text { rações }\end{array}$ & $\checkmark$ & $\checkmark$ & & & & $\checkmark$ \\
\hline 10 & Jones (2011) & $\begin{array}{l}\text { Redes de relações em } \\
\text { uma empresa }\end{array}$ & & & & $\checkmark$ & $\checkmark$ & \\
\hline 11 & $\begin{array}{l}\text { Nash e Shaffer } \\
(2011)\end{array}$ & $\begin{array}{l}\text { Complexidade das re- } \\
\text { lações num jogo epis- } \\
\text { têmico }\end{array}$ & $\checkmark$ & $\checkmark$ & & & & $\checkmark$ \\
\hline 12 & $\begin{array}{l}\text { Nicholas e } \mathrm{Ng} \\
(2009)\end{array}$ & $\begin{array}{l}\text { Interações online na } \\
\text { formação de professo- } \\
\text { res }\end{array}$ & $\checkmark$ & & & & & \\
\hline 13 & $\begin{array}{l}\text { Eames } \quad \text { e } \\
\text { Stewart (2008) }\end{array}$ & $\begin{array}{lr}\text { Comunidades } & \text { de } \\
\text { aprendizagem } & \mathrm{e} \\
\text { relações interpessoais }\end{array}$ & $\checkmark$ & & & & & \\
\hline 14 & $\begin{array}{l}\text { Angeli e Valain- } \\
\text { des (2008) }\end{array}$ & $\begin{array}{l}\text { Discussão assíncrona } \\
\text { em fóruns }\end{array}$ & & & & & & \\
\hline 15 & $\begin{array}{l}\text { Hug e Reese } \\
(2006)\end{array}$ & $\begin{array}{l}\text { Integração da tecno- } \\
\text { logia e ensino de Ci- } \\
\text { ências e Matemática }\end{array}$ & & & & & & \\
\hline
\end{tabular}

Fonte: elaboração nossa.

As redes serviram para análise de relações semânticas (ou de significados), caracterizada em dois dos 15 trabalhos. Serviram também para análise de relações sociais, presente 
em três dos 15 trabalhos, podendo ser estudada presencialmente ou a partir de registros on-line. Ainda, a análise de redes serviu também ao propósito de construção de estruturas híbridas ou estruturas relativas a aspectos nem do social nem do semântico. Essas outras representaram um total de cinco dos 15 trabalhos retornados.

\subsubsection{Rede-comunidade de co-autorias do levantamento}

Uma metautilização das redes foi procedida, de modo a produzir uma rede híbrida em multiníveis de relação, de modo a entender a formação da comunidade global da pesquisa em Educação em Ciências, na perspectiva da análise de redes.

Figura 19 - Rede cientométrica. Círculos representam autores, com diâmetro proporcional ao número de aparições; triângulos representam o tipo de rede utilizada explicitamente nos trabalhos; hexágonos representam as revistas científicas que apareceram mais de uma vez. Abaixo, destaque para os papéis das revistas (inferior esquerda) e dos temas (inferior, centro) como pontes entre grupos e destaque para as comunidades de aglomeração das publicações.

Rede híbrida multinível de co-autorias
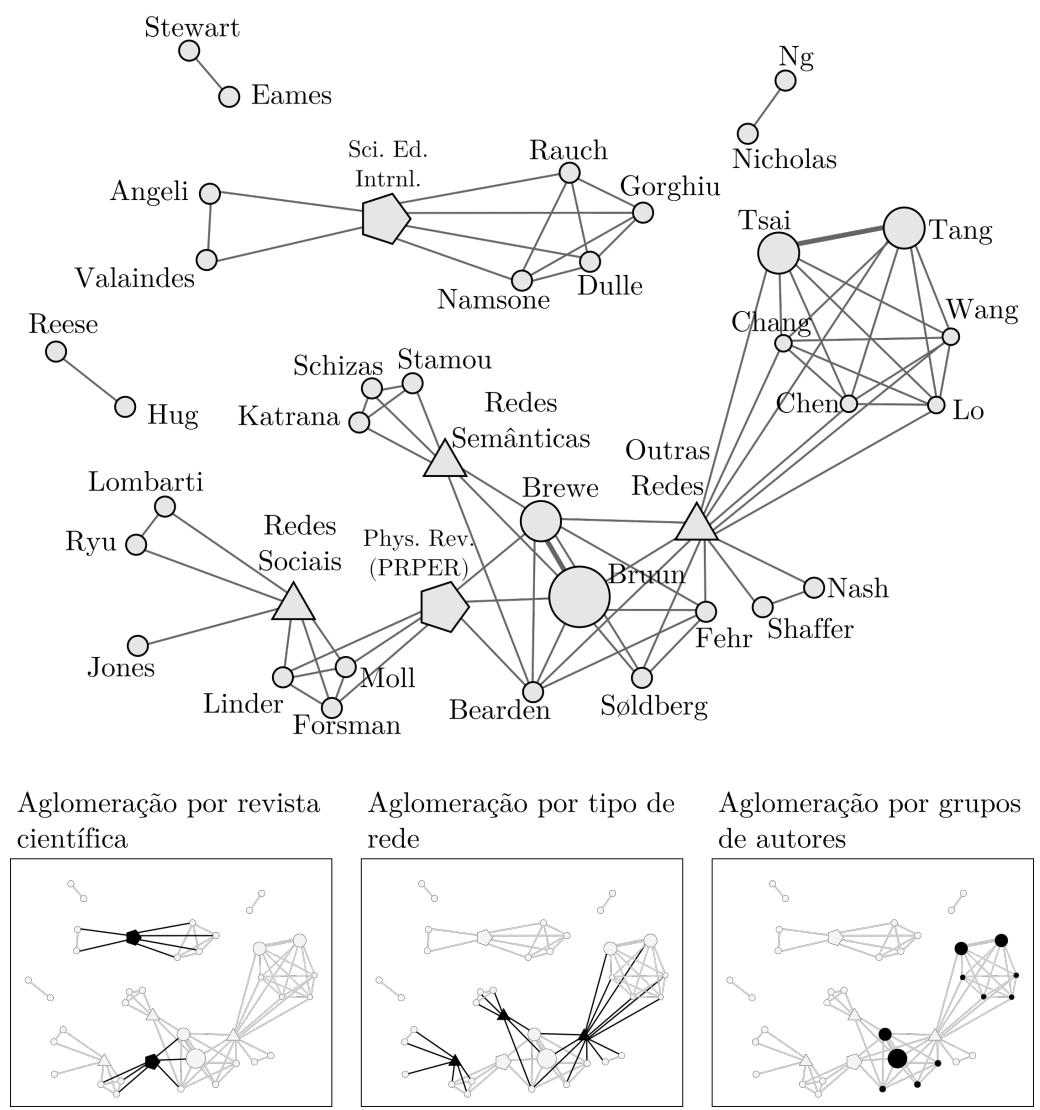

Aglomeração por grupos de autores

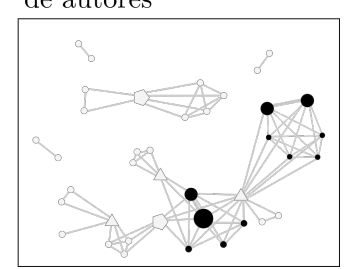

Fonte: elaboração nossa. 
Nessa rede daqueles que usam redes, consideramos como primeiro nível de relação, as co-autorias. Então, dos 15 artigos retornados, para cada trabalho com dois ou mais autores, construiu-se uma rede de relações como todos os autores conectados entre si, mostrada na Figura 19, acima.

Como há uma aglomeração proeminente em duas revistas científicas, todos os autores com trabalhos nessas duas estão também a elas ligados (Fig. 19, inferior, à esquerda). Não representamos as revistas únicas pelo fato de elas ainda não figurarem um fator de aglomeração entre diferentes comunidades de autores.

Ainda, diante da polissemia das redes, separamos três usos (redes sociais, redes semânticas e outras redes) e representamos como sendo outro fator de aglomeração de autores (Fig. 19, inferior, ao centro). Um outro fator de destaque é a concentração numérica de publicações em duas comunidades de autores (Fig. 19, inferior, à direita), que sozinhas agregam $\frac{1}{3}$ de todos os trabalhos retornados.

\subsubsection{Discussão do panorama}

O levantamento indica, em linhas gerais, uma gênese de comunidade acadêmica no cenário global, que utiliza a perspectiva das redes para produção de saber acerca de numerosos objetos de pesquisa. A metautilização das redes para entendimento desta comunidade, fornece, em mais detalhe, alguns aspectos marcantes dessa comunidade.

Tendo o maior número de trabalhos concentrados em uma revista especializada em pesquisa em ensino de Física, vemos um indício de que o uso das redes, na pesquisa educacional, se inicia naquela comunidade que trata das redes como matriz técnica e que domina a manipulação da rede-ferramenta. Mas a dispersão da ideia nos outros textos retornados, mostra que o acesso às ferramentas de análise de redes não determina um impeditivo para procedimento da pesquisa em outras áreas e por pesquisadores que não sejam experts em programação ou na dita Network Science. Essa vulgarização da ferramenta, especialmente com a popularização de softwares dedicados, gratuitos, (alguns serão descritos à frente, nesta tese) é um processo fundamental para que a abordagem seja abraçada por outras áreas. 
Por exemplo, operando a análise de redes no domínio estritamente semântico, Schizas e colegas trazem a abordagem para a investigação da estrutura relacional entre conceitos ligados à ecologia com estudantes do ensino fundamental. No domínio semântico, conforme descrevem os autores, o uso das redes é viável, pois assume-se que "[...]o conhecimento declarativo dos estudantes forma um todo estrutural que, numa forma idealizada, pode ser representado como uma rede associativa de conceitos conectados" (SCHIZAS; KATRANA; STAMOU, 2013, p. 176, tradução nossa). Então, os autores procedem medições estruturais das redes para inferir aspectos da estrutura cognitiva dos estudantes. Há que se notar o destaque dos autores, pois a estrutura inferida é sempre idealizada, rejeitando-se a posição realista ingênua e reconhecendo a rede como artefato.

Na outra direção, Ryu e Lombardi (2015) partem de uma análise crítica do discurso para construírem redes no domínio estritamente social. Os autores utilizam redes sociais para avaliar as mudanças de engajamento dos alunos, no tempo, em função de suas participações na estrutura da comunidade da sala de aula. Para isso, os autores declaram aporte na premissa básica da análise de redes sociais, na qual se assume que:

os indivíduos que compõem uma rede são influenciados pela organização estrutural da rede. As posições dos indivíduos na estrutura, são traçadas por uma análise do número, do formato e do comprimento dos nós $s$ dos caminhos, isto é, quem conhece quem e quem compartilha o quê com quem. A análise de redes sociais produz diagramas que consistem de nós e linhas. Cada membro da rede social é representado por um nó e cada linha conectando dois nós representa uma interação entre dois membros

(RYU; LOMBARDI, 2015, p. 76, tradução nossa)

Vê-se que a análise das redes pode ser direcionada à estrutura relacional de conceitos, bem como à estrutura relacional de ideias. No entanto, um passo inerente ao pensamento da complexidade é a intenção de inclusão de aspectos de mais de um domínio, mas que estejam relacionados a um todo mais amplo. Para isso, as redes precisam transbordar o caráter metodológico desta ou daquela disciplina. Conforme destacam Bruun e Brewe (2013):

a perspectiva das redes em relação aos dados, assume que os dados são relacionais e interdependentes, cada nó dentro de uma rede tem características ou atributos que são independentes de outros nós; esses podem 
ser utilizados em conjunção com medidas reticuladas para constituírem resultados preditivos

(BRUUN; BREWE, 2013, p. 6, tradução nossa)

Os autores acima utilizam uma rede mista de correlações, na qual não estão apenas interessados em representar a sala de aula pelo viés semântico/cognitivo ou pelo viés social. De modo mais abrangente, os autores exploram diferentes aspectos das relações entre estudantes, mostrando, dentre eles, uma forte correlação entre a rede social formada intra-classe pelos alunos e a performance (notas) deles.

Outro caso de uso das redes como aspecto integrador na pesquisa em Educação em Ciências, são as redes epistêmicas de Nash e Shaffer (2011). Nelas, redes sociais e conexões entre quadros epistêmicos construídos por alunos são mescladas. Para os autores, as redes epistêmicas permitem "[...] olhar quando e quão frequentemente os elementos [dos quadros epistêmicos dos estudantes] são conectados." (NASH; SHAFFER, 2011, p. 176, tradução nossa), palavras que mostram, novamente, que o traço marcante é o aspecto relacional entre elementos de diferentes domínios. Mesmo que esses autores, no trabalho retornado, tenham optado por não apresentar as ditas redes epistêmicas, em uma representação imagética típica de grafo, eles analisam o desenvolvimento das redes a partir da centralidade dos elementos nelas conectados.

\subsubsection{Considerações finais da revisão sistematizada}

A diversidade de usos das redes marca a revisão sistematizada. Vê-se nas publicações mapeadas que as redes são artefatos adequados tanto para a investigação de aspectos sociais, quanto para a investigação de aspectos cognitivos. No entanto, chama a atenção o fato da rede habilitar análises que acoplam os diferentes domínios. Isso mostra proximidade desta tese a essa nova forma de estudo da sala de aula, a partir de uma perspectiva relacional.

A revisão sistematizada indica o uso das redes na investigação em Educação em Ciências como campo a ser expandido. Isso reforça a justificativa central desta tese, que intenta se figurar uma contribuição nesse cenário ainda em processo de desbravamento. 
Há, contudo, a ressalva que sempre deve ser direcionada aos trabalhos metacientíficos: não se pode assumir que o cenário de fato da pesquisa é completamente capturado pelo processo de revisão sistematizada.

Mas as incertezas típicas da cientometria, seja em relação às chaves de procura, aos descritores utilizados, ao recorte temporal ou quaisquer outras, não devem ser tomadas como negação do panorama encontrado. Ao contrário, são alertas animadores que nos fazem manter o radar atento a outros trabalhos e outras comunidades de produção acadêmica que podem estar em linhas muito próximas a esta tese, mas talvez sobre outras etiquetas. 


\section{Redes de ideias e redes de pessoas}

Qualquer que seja a etiqueta, a questão é sempre a de reatar o nó górdio, atravessando, tantas vezes quantas forem necessárias, o corte que separa os conhecimentos exatos e o exercício do poder, digamos a natureza e a cultura.

Bruno Latour

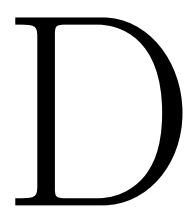

ENTRE as diferentes formas de utilização das redes na pesquisa em educação em ciências, duas correntes podem ser destacadas, conforme ressaltamos anteriormente, na Seção 1.4. Numa delas, as redes de ideias se valem da ciência das redes como lente de observação para processos de formação e evolução de conceitos. Isso é feito com intenção de se analisar o reino dos indivíduos, tomando-se as ecologias conceituais individuais como objeto de análise. Mas isso também pode ser feito para se analisar o reino da coletividade, tomando-se como objeto de análise, as representações partilhadas por múltiplos indivíduos.

Na outra corrente, a noção das redes é utilizada para se analisar como os indivíduos, em si, compõem uma estrutura. Redes são, nesses casos, utilizadas para análise do processo de estruturação interpessoal, da formação de grupos, propriamente ditos. Nessa outra vertente, formas de conexão entre pessoas são pensadas para se agregar um coletivo, um microssocial da sala de aula, que, ao mesmo tempo, influencia as redes de ideias e por elas também é influenciado.

Por isso, neste capítulo, abordamos duas veias teóricas que dão suporte a essas redes. A Teoria das Representações sociais, na qual as redes de ideias coletivas se situam e, mais à frente, a Análise de Redes Sociais, na qual as redes de pessoas tomam forma e ganham poder explicativo. 


\subsection{Representações Sociais e a teia complexa de ideias}

\subsubsection{E o povo não quis que mudassem o nome}

Inicio com um caso concreto, tomando emprestado e regionalizando o exemplo proposto por Duveen (2015). No extremo sul do estado do Espírito Santo, uma cidade limítrofe de sua gêmea, no estado do Rio de Janeiro, provoca discussões em conversas informais dos capixabas. A cidade, localizada no austro capixaba, tem o nome de Bom Jesus do Norte (Fig. 20, B).

Figura 20 - Mapa do Brasil (A), destaque para o estado do Espírito Santo e a cidade austral Bom Jesus do Norte (B) e destaque para a cidade fluminense de Bom Jesus de Itabapoana, ao sul do Rio Itabapoana e a cidade capixaba Bom Jesus do Norte, ao norte do Rio Itabapoana (C).

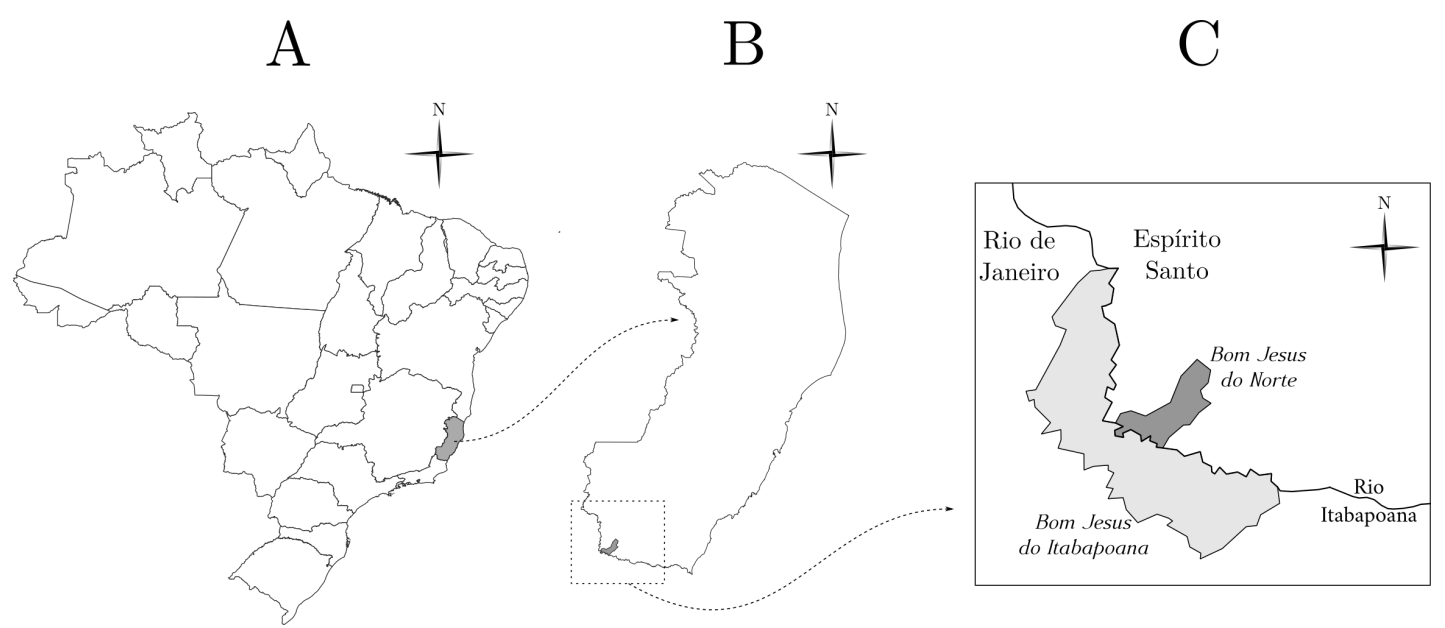

Fonte: elaboração nossa.

A confusão estabelecida entre o nome e a localização da cidade é descrita por Araújo (2019) em reportagem de abrangência nacional:

Para minha surpresa, Bom Jesus do Norte, não ficava no norte do estado, e sim no sul. O norte é porque a cidade fica na parte norte do rio Itabapoana. [...] um prefeito até tentou há um tempo atrás mudar o nome da cidade pra Bom Jesus do Sul, mas o povo não deixou.

(ARAÚJO, 2019)

Se direcionarmos a atenção à parte final do excerto, a afirmação indica que os cidadãos da localidade produziram para aquela localidade, uma imagem que se cristaliza 
no mundo social por seu nome, mesmo que para forasteiros isso possa ser confuso. É possível especularmos o processo relativo à formação da imagem para a localização da cidade, algo que mistura informações institucionalizadas e o senso comum dos cidadãos: o poder público em algum momento histórico determina o nome da cidade, utilizando como referência o rio que separa os dois estados e não a sua localização em relação às demais cidades do estado do Espírito Santo. Isso, com o tempo, passa a permear o imaginário das pessoas, que validam de maneira informal o nome da cidade.

De modo natural, os moradores locais, que têm diariamente a vivência com a cidade gêmea, ao lado sul da ponte que une os dois estados, lançam mão dessa imagem para que possam lidar com as demandas diárias. Isso se torna artefato das práticas da vida para aqueles que atravessam a ponte diariamente, seja para trabalhar, seja para comprar ou vender produtos. Mesmo que o nome de uma cidade seja tipicamente definido numa instância normatizada institucional, por um grupo pequeno de indivíduos tomadores de decisão, com o passar dos anos, isso se torna identidade dos moradores. Faz com que os cidadãos se familiarizem com as localidades de um lado e do outro. Mesmo estando no extremo sul do Espírito Santo, usam o termo "norte" de modo consensual, cotidiano.

Trata-se, por tanto, de um conhecimento de senso comum. Um processo psicossocial no qual há um conhecimento produzido e transmitido entre moradores da região. Tal produção/transmissão não ocorre prontamente com as demais regiões do estado. Um tanto pela distância geográfica da região metropolitana da capital capixaba e Bom Jesus do Norte, no extremo sul do estado. Um outro tanto pela diferença de vivências e práticas cotidianas dos moradores de uma e de outra localidade. A menos da existência de alguma vivência na, ou de alguma relação com a região, um cidadão a quem se apresente o mapa do estado com destaque ao município padeceria da mesma confusão.

Esse exemplo tomado (declaradamente) do caso de Duveen, quem utiliza cidades na Europa, é uma alusão ao fenômeno que conheceremos como Representação Social. Um processo pelo qual os padrões de comunicação se ajustam a demandas da vida. No qual o conhecimento se imbui de validade pelos compartilhamentos em uma comunidade. Representações Sociais são processos inerentes a agrupamentos sociais. São fenômenos nos 
quais imagens que reflitam as formas compartilhadas de pensamentos, juízos e crenças sobre um determinado evento ou tema são criadas. Compõem um corpo de conhecimentos que permeiam a vida das pessoas constituintes de um grupo social. Mais que isso, as representações compõem a realidade social das pessoas. Pelas representações compartilhadas socialmente, um grupo promove um universo consensual no qual se torna familiar àquilo que outrora fora não-familiar.

\subsubsection{Nascimento da Teoria das Representações Sociais}

Inaugurada por Moscovici (1978) (originalmente, 1961), a Teoria das Representações Sociais (TRS) é posta como forma de entender a imagem que os diferentes grupos sociais construíam sobre a psicanálise. Esse objeto de investigação na obra inaugural da teoria é escolhido com uma intencionalidade clara: mesmo que uma investigação das representações pudesse ser procedida com qualquer outro objeto, como a imagem que as pessoas constroem sobre a ciência, Moscovici preferiu analisar as representações de um objeto que não possuía o status de ciência empírica.

A psicanálise era, assim, uma não-ciência, se o modelo poperiano ${ }^{1}$ de validação da ciência for tomado como parâmetro. Uma vez que não se valia dos processos de refutação de hipótese e de reprodutibilidade, tão institucionalizadores das ciências naturais, as potenciais imagens que os grupos sociais produziriam sobre a psicanálise indicariam a dinâmica e a riqueza do fenômeno de produção de representações e sua penetração no senso comum. Nesse sentido, uma representação social é uma organização de imagem e linguagem que simbolizam atos e situações que nos unem e que nos tornam comuns.

Ao lidar com conhecimentos do senso comum, Moscovici propõe uma separação desses e das representações, dos mitos e das tradições populares mais estáveis. Faz isso buscando recuperar o "conceito perdido" das representações. Diferente da rigidez dos mitos e das tradições estáveis, mais rígidos, as representações, em Moscovici, são acontecimentos dinâmicos, emergências da vida social. Por isso, são ferramentas que permitem a lida com

\footnotetext{
${ }^{1}$ em referência aos trabalhos de Karl Popper, nos quais o falseamento de uma teoria é defendido como característica necessária ao método científico
} 
o mundo. Isso coloca as representações mais como um fenômeno do que como um conceito.

Isso indica dois modos, um modo passivo e um ativo, de se encarar as representações. No modo passivo, funciona como um reflexo do mundo. Uma forma de apreender na consciência individual ou coletiva, um conjunto de ideias e de objetos que nos são dados do exterior. De modo ativo, as representações modelam aquilo que nos é dado no exterior. Assim, indivíduos ou grupos se relacionam com os objetos e com as situações do exterior, por causa das, e no decorrer das, interações com outros.

Moscovici avalia que as representações, embora sejam dinâmicas, também podem ser reproduzidas. Mas a reprodução "[...] implica um remanejamento das estruturas, uma remodelação dos elementos, uma verdadeira reconstrução do dado, no contexto dos valores, das noções e das regras" (MOSCOVICI, 1978, p. 26). Vemos nesse posicionamento uma forma próxima àquela de Sewell (2005) para analisar reprodução e transformação culturais. As representações sociais, como vistas por Moscovici, se assemelham aos esquemas de ação e aos recursos. Há, também nas representações, uma dualidade entre a reprodução e a transformação.

Embora Moscovici admita tomar da sociologia a noção de representação, especialmente dos trabalhos de Durkheim, ele distingue sua versão da versão sociológica. Moscovici (2015) descreve as representações coletivas, de Durkheim, como tendo um aspecto de objetos estáticos. Inerentes, sim, aos grupos sociais, mas pensados como produtos deles. Mesmo que não se negue a existência de representações conforma propusera Durkheim, o problema apontado é que aquela perspectiva não explorava nem sua estrutura interna e nem sua dinâmica.

Ainda que ambos convirjam no ponto de que a vida social e pensamento organizado são condições interdependentes, o que leva à conclusão que havendo agrupamentos sociais humanos, haverá compartilhamento de representações, há um afastamento entre os dois autores noutro aspecto: as representações coletivas seriam um conceito, um referente com poder explicativo que abarca uma classe geral de ideias e crenças, como mitos, ciência, religião e outros. Já as representações sociais de Moscovici, são colocadas como fenômeno, acontecimentos cuja estrutura é continuamente ajustada, reconstruindo o senso comum a 
cada instante.

Sendo as Representações Sociais fenômenos da lida com o mundo, o sentido da palavra representação pode atuar de duas formas, como defendido, em outro trabalho, por Moscovici (1988). Num sentido, representações, como vorstellungen (representação mental, em alemão), que pode ser pensada como o ato de transformar em linguagem uma demanda intelectual. De representar uma ideia. De materializar, na linguagem, um pensamento compartilhado. Numa linguagem cuja função comunicativa fosse possível. Logo, linguagem com possibilidades consensuais. No outro sentido, representações como darstellungen (representação materializada, em alemão), pensada também como ato, como a ação de atuar, que pressupõe performar socialmente. De conferir um papel social aos indivíduos. As sutilizas dos dois termos que, em língua alemã, se diferenciam, reforça o fato de que as representações estão a serviço de demandas sociais de diferentes ordens. Os dois sentidos permitem também que uma imagem opere, ao mesmo tempo, de maneira passiva e ativa: refletindo o que está no exterior para o interior; se vale daquilo que é interior para agir no exterior.

Sem nos afastarmos do nosso locus de investigação desta tese, que é a sala de aula, vemos que os elementos comunicados naquele ambiente também são imagens que assumem as duas funções. São demandas intelectuais que os alunos têm, ao se depararem com as disciplinas curriculares. Essas vêm de uma ciência solidamente institucionalizada, com regras definidas e comunidades de produção ideias bem traçadas, perfeitamente posicionadas como o Saber Sábio de Chevallard (1991). Essa demanda é traduzida em linguagem. Passa a ter função comunicacional. Passa a ser reconhecida, compartilhada.

Para além dessa função, o fenômeno das representações, quando produzidas por um grupo de alunos, também opera a outra, de dentro pra fora. As pontes comunicacionais entre alunos, estabelecidas pela linguagem ou por símbolos figurativos compartilhados, são artefatos com os quais os alunos podem contar para lidar com aquela realidade (micro)social escolar. Em seu processo de escolarização, a vida social passa a apresentar novas demandas e, buscando lidar com elas, os alunos produzem novas representações, ajustam outras antigas, constroem um novo senso comum. 
A dualidade entre os sentidos de representação indica duas formas de concepção da representação social: elas são uma situação social e são um sistema cognitivo (MOSCOVICI, 1978). Enquanto situação social, as representações sociais se formam $(i)$ pela dispersão da informação, que recheiam um objeto social de dados, mesmo que estes não sejam suficientes para erradicar as incertezas sobre o objeto; $(i i)$ pela pressão por inferências, que exige, em situações cotidianas, posicionamentos por parte dos indivíduos, mesmo que não tenham uma posição sólida ou organizada sobre ele, algo que promove desvios nas operações intelectuais; e (iii) pela focalização dos indivíduos e dos grupos em um centro de interesse, algo que constrange as formas de produção de reflexão.

Por outro lado, enquanto sistema cognitivo, as representações se formam $(i)$ por um formalismo espontâneo, uma vez que o senso comum não se sujeita à instâncias institucionalizadas; ( $i i$ ) pelo dualismo causal, uma vez que, no senso comum, as causalidades se vinculam tanto a um contexto de intenções quanto a uma sucessão de acontecimentos, que levam a um (iii) predomínio da conclusão, por vezes em detrimento da análise; e $(i v)$ por uma pluralidade dos tipos de raciocínio, o que permite a acomodação de diferentes formas de processamento de informações.

A existência de diferentes modos de conhecimento, em diferentes estágios de desenvolvimento, que coexistem nos indivíduos e que são necessários para produção de representações, indicam uma polifasia cognitiva (JOVCHELOVITCH, 2006). A depender das diferentes demandas que a situação social exige, diferentes modalidades de conhecimento são ativadas. Desde as formas operatórias da cognição, associando, diferenciando, incluindo e excluindo informações, até a forma normativa da cognição, na qual as informações operatórias são selecionadas e elaboradas, dentro de um quadro de normas que seja validado pelo grupo.

Não há razão para julgarmos que esse processo seja linear, pois uma cadeia causal do surgimento de uma representação depende de uma multitude de fatores, internos e externos, do elemento para o sistema e do sistema para os elementos. Também não há razão para pensarmos nas representações como subjugadas a um controle central, hierarquizador. As representações emergem. As representações também se retroalimentam. Por tudo isso, 
a complexidade é característica do campo representacional. É da complexidade que surgem as saliências de estabilidades, tão efêmeras quanto necessárias para organização local da coletividade. E isso se dá por dois processos-chave.

\subsubsection{Processos}

Dois principais processos, inerentes às Representações Sociais, se desdobram para sua formação: a objetivação e a ancoragem. Ambos necessários à construção da realidade, mediante representações. Jodelet (2008) apresenta a ancoragem como sendo o processo que explica de que forma o sentido é atribuído a objetos não-familiares, a partir de sua inserção em um quadro conceitual existente. Isso ocorreria a partir da nomeação, classificação e interpretação de objetos sociais.

Esse processo de ancoragem não trata apenas de etiquetar novos elementos. Mas sim de encontrar, no sistema complexo conceitual pré-existente, referentes que permitam a formação de sentido, ancorando o novo, o não-familiar. Chama a atenção que Moscovici sugere que não se trata de acrescentar um elemento novo a uma rede de conceitos, mas sim de transferir a rede de conceitos para uma esfera conveniente de produção de sentido sobre o novo, conforme escreve:

Uma característica importante mas, comumente negligenciada, da ancoragem é a transferência de uma rede de conceitos e imagens de uma esfera para outra, onde ela, então, serve como modelo

(MOSCOVICI, 1988, p. 235, tradução e grifo nossos)

Se, de um lado essa transferência da rede promove à entidade um sentido para a vida cotidiana, de outro, tem-se a objetivação da entidade. A objetivação é a seleção de informação e sua esquematização que permite a projeção de um constructo em entidades da vida cotidiana, que segundo Jodelet (2008), permite a naturalização do objeto. As entidades se objetificam por sua transformação em símbolos, sem que concluam o processo, pois quando conceitos e imagens se tornam objetificados, não são mais estranhos e, por isso, passam a ser como elementos contidos em si. Como palavras que se transformam em clichês. Como também ideias que, mesmo contraditórias, convivem sem se cancelar. 
Moscovici (1988) reforça que, uma vez objetificadas, as entidades atingem o ponto de serem de todos e, ao mesmo tempo, de ninguém.

\subsubsection{Dois universos}

Objetivação e ancoragem são processos que ocorrem simultaneamente, dada a dinâmica da formação das representações sociais. Então as representações podem emergir de um grupo, promovendo um ambiente de compartilhamento de verdades, entre os membros do grupo. Porém, esse universo pode se apresentar em dois âmbitos diferentes. Num deles, as ideias são validadas a partir de uma lógica dita científica, que respeitamos como erudita e válida. No outro, as ideias se validam pela vulgarização da entidade representacional. Algo que se dá na formação de consensos em um grupo. E que não opera dentro da lógica das ciências ditas sagradas (nas palavras de Moscovici). Entretanto, as ideias validadas nos consensos podem ser igualmente, quiçá mais, poderosas que aquelas validadas nas ciências.

Por isso, Moscovici (2015) contrasta os dois âmbitos, referindo-se a eles como ciências sagradas e a ciências profanas. Nas ciências sagradas, um universo reificado é composto por normas, classes e ideias, materializadas em documentos, leis, contratos e publicações científicas, que determinam o que é válido ou não. Em um universo reificado tem-se $(i)$ uma sociedade constituída de um conjunto de entidades sólidas; (ii) uma ciência que se sobrepõe à experiência individual, por sua autoridade de pensamento; e (iii) uma impossibilidade de que cada indivíduo decida o que é verdadeiro ou não, pois essa liberdade é suprimida pelas instâncias institucionais reificadoras.

Nas ciências profanas, o âmbito do universo consensual é composto por fatos não normatizados. É um universo no qual todos os participantes tem igual autoridade de pensamento e igual importância e validade. No universo consensual tem-se $(i)$ uma sociedade vista como um conjunto de indivíduos livres para falar por si e pelo grupo; $(i i)$ a possibilidade de que verdades sejam produzidas e validadas por qualquer indivíduo; e (iii) os locais públicos de encontro são palcos de produção e validação das verdades, pois a vivência, a experiência individual e coletiva se sobrepõe às normas reificadas. 
A academia, a produção científica, mesmo a defesa do presente trabalho, se situam num universo reificado. Instancias institucionais organizam na forma de normas as formas de validação do conhecimento. Mas de outro lado, um grupo de pessoas reunidas numa praça e discutindo um tema de interesse comum, promove representações que se objetificam como elementos de seus cotidianos. Não havendo, nesse caso, uma assimetria da autoridade sobre o conhecimento. As expressões de seus pontos de vista criam realidades nas quais o coletivo decide o que é verdadeiro ou não.

Para nós, neste trabalho, a tensão entre o universo consensual e o universo reificado é particularmente interessante para pensarmos as redes de ideias da sala de aula. Os alunos, em processo de escolarização, lidam com demandas mistas, vindas tanto de um quanto do outro universo. A instituição escola opera num universo reificado, mas as ideias dos estudantes são povoadas de vivências do universo consensual. Os dois universos são indissociáveis aos alunos. Eles lidam com as entidades reificadas como o currículo e o sistema de avaliação, mas que também lidam com as entidades consensuais, uma vez que há uma sobreposição de tudo que a escola traz a eles e de todas as redes de ideias pré-existentes formadas por suas demandas diárias, e que são utilizadas para ancorar aquilo que é não-familiar. Logo, as representações formadas em sala de aula emergem dessas complexidades sobrepostas. E como a análise da complexidade se vale do pensamento sistêmico, das noções constitutivas e do uso das redes, podemos chamar a atenção para uma das abordagens dos estudos das representações sociais, peculiarmente atinente à complexidade.

\subsubsection{Abordagem estrutural}

Há uma contradição inerente às representações sociais. Elas são rígidas/estáticas o suficiente, de modo que cooperam para construção de um sistema de valores. No entanto, elas também são, ao mesmo tempo, fluidas/dinâmicas, tal que permanecem em constante mutação. Então as representações são formas de produção de consensos, minimamente estáveis, mas são também fortemente marcados por idiossincrasias difusas e instabilidades. Mas neste caso, como se pode olhar um processo dotado dessas características contrastantes? 
Ao revisar a gênese dessa contradição inerente, Sá (1996) recupera uma solução teórica proposta: uma representação social possui, na verdade, uma estrutura na qual se diferenciam dois conjuntos. Um conjunto, mais estável, é marcado pela memória coletiva, valores e condições históricas. É um conjunto mais rígido. Sua existência não depende dos contextos, material e social, imediatos. É resistente à mudança e, por isso, confere uma continuidade e uma homogeneidade ao grupo. Esse conjunto é o que forma o chamado núcleo central de uma representação social. O outro conjunto, que forma o chamado sistema periférico da representação social, configura os elementos de menor continuidade e que são mais dependente dos contextos, material e social, imediatos do grupo.

Proposta inicialmente por Abric (1993), a abordagem estrutural das representações sociais foi uma solução proposta para tornar viável a lida com essas contradições. Como saída, a estrutura de uma representação social é pensada como sendo composta por, ao menos, dois conjuntos, cujas funções são específicas. Um nuclear e outro periférico, mas cujas bordas não seriam claramente delimitadas. Enquanto o núcleo central tem função consensual e estabilizadora, a região periférica serve de interface entre o mundo concreto e o núcleo. A periferia confirma o núcleo. E ainda permite que os indivíduos modulem a representação. Por isso, à periferia atribui-se uma dinâmica evolutiva. Na periferia, a contradição e a heterogeneidade do grupo são acomodadas. As experiências e as histórias individuais se integram.

Investigar as representações sociais a partir de uma abordagem estrutural permite, conforme avalia Sá (1998), a observação as mudanças numa representação seja (i) para um grupo, a partir do foco em elementos da periferia, ligados ao contexto material e social, e, por tanto, sofrendo as pressões evolutivas vindas da prática social, seja (ii) entre grupos, a partir do potencial informativo do núcleo, que depende menos do contexto material e social e que é mais homogêneo. Por isso, na abordagem estrutural as regiões do núcleo e da periferia, que garantem a estabilidade e a dinâmica, respectivamente, do processo representacional de um grupo social, são focos de interesse.

Entretanto, há que se observar que nem todo objeto representacional tem relevância ou "densidade" social. Por isso, Sá (loc. cit) alerta que alguns objetos, justamente por 
apresentarem maior relevância em relação aos grupos sociais que sobre eles constroem imagens, podem ser mais viáveis para pesquisa em representações sociais. Dessas temáticas, Sá lista: a relação da ciência com o pensamento erudito e o pensamento popular; a saúde e a doença; o desenvolvimento humano; a educação; o mundo do trabalho e das organizações; o estudo das comunidades e afins; e a exclusão social. Enquanto pesquisa em educação em Ciências, há uma aproximação nítida entre esta tese e as temáticas primeira e a quarta, de Sá. Essa aproximação também é defendida por Alves-Mazzotti (2008), para quem a adoção do olhar psico-social favorece o impacto da pesquisa em educação sobre a prática educacional. Isso porque esse olhar preenche o sujeito social de um mundo interior, enquanto restitui o sujeito individual ao mundo social.

Nesse sentido, Santos (2007) trabalha com um grupo de 60 licenciandos, aspirantes a professores de Ciências do ensino fundamental, para discutir uma crise na relação entre o público amplo e o conhecimento formal da Ciência. Uma imagem da Ciência como produto dado e não como construção humana, bem como um distanciamento entre objetos científico/tecnológicos e a sociedade é vista nas representações dos professores em formação, despertando um alerta sobre o quanto a quebra da reprodução desse modelo deve ser promovida por professores.

Em outro estudo, a imagem da Ciência também é explorada por Melo, Tenório e Accioly (2010), que investigam 26 licenciandos em Física. Esses autores mostram a prevalência de uma visão idealista da Ciência, permeando o universo consensual dos licenciandos. A consolidação da utilização das Representações Sociais na pesquisa educacional também pode ser vista desde trabalhos tomando como objeto de pesquisa as representações do grupo de professores (ALMEIDA; CUNHA, 2003; RIBEIRO; JUTRAS, 2006) e em trabalhos cujos objetos são as representações de grupos de estudantes (OLIVEIRA et al., 2001; CARBONE; STÉFANO, 2004). São casos nos quais a investigação dos saberes consensuais de grupos, são o fator informativo sobre o grupo.

Isso, de certa forma, autoriza o uso desse aporte teórico para iluminarmos um aspecto da complexidade da sala de aula. Na abordagem estrutural, observam-se as representações a partir de um viés sistêmico, que é próximo à lente das redes complexas, 
pivô desta tese. E isso tem implicações também no campo metodológico: estruturas linguísticas formam uma rede complexa de associações entre termos que sejam, para os participantes do grupo social, mais semelhantes ou não, dado um determinado objeto.

Essa rede de associação de palavras pode ser investigada empiricamente, a partir de testes de associação. O estudo de associação de palavras é uma forma de investigação historicamente sedimentada de pesquisa nos campos da psicologia e da psiquiatria. Numa perspectiva do indivíduo, serve parar análise de relações entre ideias ou emoções ou formação de conceitos (MERTEN, 1992).

Do ponto de um grupo, é uma abordagem adequada ao levantamento e à análise de representações. A ideia de coletar evocações feitas por membros de um grupo, em relação a termos indutores específicos, já era utilizada por Giacomo (1980), para quem a associação livre de palavras tem como vantagem deixar que as categorias significantes sejam escolhidas pelos sujeitos. Isso, de um lado, pode inserir ruído na análise, mas de outro, torna a análise mais próxima do grupo.

Em relação à abordagem estrutural de Abric (1993), a observação de redes de associação de palavras podem indicar elementos nucleares ou periféricos, a partir da conectividade das palavras na rede. É o que sugere Moliner (1994), ao dizer que elementos do Núcleo Central de uma representação carregam valor simbólico e tem maior capacidade de conexão com outros. Dessa forma, a partir da complexidade das associações entre palavras, as regiões nucleares e periféricas, que emergem como representação do grupo, se tornam visíveis. As estruturas vistas nas redes de associações de palavras são, então, representativas das ideias, dos consensos e dos dissensos de um grupo. São redes de um saber coletivo, formadas pelas práticas sociais e modeladoras das práticas sociais do grupo.

\subsection{Redes sociais e complexidade das relações interpessoais}

Ao explorarmos a complexidade da sala de aula por suas redes emergentes, nos mantemos atentos ao fato de que tal complexidade se manifesta em múltiplos níveis de análise. Se, acima, discutimos como essa complexidade é manifesta na produção de 
representações em um grupo, ou seja, no âmbito psicossocial, aquela não é a única dimensão de sua manifestação. Os alunos se relacionam continuamente e essas afiliações que estabelecem uns aos outros, em sala de aula, promove a emergência de uma estrutura que é local e que, mesmo sendo dinâmica, molda o (e é moldada pelo) ambiente que conhecemos como sala de aula.

Há, nessa estrutura, um jogo complexo de associações interpessoais. Isso é, como em qualquer outro agrupamento humano, inerente ao fato de estarem diariamente reunidos e em interação. Nesse sistema complexo de associações, conforme explicam Silva e Regis (2015), as redes são um sistema interacional de atores ou uma comunidade não geográfica, remetendo ao conceito central da topologia, que apresentamos na Seção 2.3 do Capítulo 2.

O estudo formal dessas estruturas tem raízes na sociologia, na antropologia e na psicologia social. Há uma diferenciação entre o argumento-chave da antropologia estrutural e a análise de redes sociais. Na primeira, as redes assumem papel descritivo e há uma busca por características estáveis que tornam as organizações e os comportamentos sociais perenes. Na segunda, busca-se olhar a rede como um referente local e momentâneo de um sistema relacional que é dinâmico e complexo. Isso demanda uma abordagem relacional e constitutiva da estrutura, considerando as características da complexidade que essa organização de associações tem.

Em sala de aula, as interações diárias promovem relações tanto explícitas quanto tácitas. Laços estruturantes que podem ser explicitados e formalizados. Essa forma de análise é também apresentada por Freeman (2004), como aspecto informativo de um grupo - não apenas da sala de aula, mas genericamente qualquer agrupamento - determinado por um contexto que fomenta padrões, tanto quanto por padrões que fomentam contextos. Freeman declara que a análise de redes sociais:

se apoia na noção intuitiva de que a padronização de laços sociais nos quais os atores estão envolvidos tem importantes consequências para tais atores. Os analistas de redes, então, buscam desvelar diferentes tipos de padrão. E eles tentam determinar as condições sob as quais tais padrões surgem, bem como descobrir suas consequências 
A dualidade agente/estrutura (Item 2.1.6, Cap. 2) é reconhecida nesse trecho de Freeman e também retoma a ontologia dos sistemas complexos, na qual são possíveis tanto causalidades de dentro para fora quanto de fora para dentro. Outro aspecto que Freeman pontua são os compromissos dos estudos que se valem da análise de redes sociais. Elenca quatro deles: são $(i)$ motivados pela noção estrutural de atores e relações; também são $(i i)$ fundamentados sistematicamente em dados empíricos; e possuem (iii) forte dependência gráfico-imagética para análise de seus resultados e, por isso (iv) dependem do uso de ferramentas matemáticas e/ou de modelos computacionais.

O trabalho da análise de redes sociais passa, em grande parte, pelo desenvolvimento dessas representações imagéticas e dos modelos que permitem interpretar as estruturações explícitas ou tácitas que estruturam a rede. Assim, na análise de redes sociais, a energia empreendida em cada forma de construção de cartografias das estruturações interpessoais é uma energia utilizada no sentido de buscar formalizações que melhor habilitem a capacidade de teorizar sobre o grupo. A interpretação e a teorização das estruturações de grupo são molas que impulsionaram o nascimento de tal campo de pesquisa.

\subsubsection{Origens da Análise de Redes Sociais}

A gênese da transposição de conceitos da topologia para o pensamento estrutural de grupos de pessoas é difusa. Mas é, certamente, esse o movimento que dá origem à análise das redes sociais. Em um aspecto, parece haver uma convergência em relação à importância da sociologia de Auguste Comte como um dos polos de pensamento que promove tal análise. Freeman (2004) aponta o comprometimento de Comte em desenvolver a sociologia enquanto ciência, e sua busca por leis sociais e por formas de produção de estudos comparativos sistematizados em sociologia, como sendo um dos momentos de início da análise de redes sociais.

A referência é também apontada por Borgatti et al. (2009), que relembra o desejo de Comte de encontrar um novo campo da física social como sendo um dos movimentos de origem para o pensamento estrutural na sociologia. Mesmo que entendamos não ser mais cabível o uso de um positivismo lógico comteano para o pensamento contemporâneo 
acerca de estruturações sociais de grupos, há que se dar o crédito ao pensador, pois fora justamente por tal interesse que se trouxe, como contribuição, a busca por um olhar sistematizado sobre agrupamentos sociais.

Scott (2011) também reconhece o papel fundamental da sociologia e, posteriormente da antropologia, na origem do pensamento estrutural de grupos. Mas reforça que fora o campo da psicologia social que promovera larga ampliação da análise de redes sociais. O aspecto topológico da análise de redes sociais é descrito por Scott:

Na análise de redes sociais, indivíduos e grupos são representados por pontos e suas relações sociais são representadas por linhas, como nos sociogramas clássicos. A teoria dos grafos oferece teoremas para a análise das propriedades formais dos sociogramas resultantes. Quando os dados de uma rede são gravados em forma de matrizes, a teoria dos grafos pode operar diretamente nas matrizes, sem a necessidade de construção de uma representação visual dos dados, em si.

(SCOTT, 2011, p. 22, tradução nossa)

Isso significa que, recuperando noções da topologia, a distância entre dois indivíduos numa rede social não é uma distância geométrica, mas sim uma distância conectiva. O excerto de Scott indica tanto o uso de ideias da topologia para análise de grupos, bem como uma tal "sociometria clássica". Ambas as noções são declaradas por Scott como fundadoras das formas atuais de análise de redes sociais.

A primeira ideia é reconhecida especialmente com a psicologia topológica de Lewin (1936), que utiliza espaço topológico como forma de análise das relações parte/todo. Lewin também defende a importância da distinção entre regiões ou elementos conectados e desconectados na psicologia. O conceito de conexão, para Lewin, era tão importante para a psicologia da percepção quanto para a psicologia da intenção, satisfação ou amizade. Para Lewin " [...] A ideia básica de uma pessoa em seu ambiente é, em seu conteúdo conceitual, uma declaração de certa relação topológica entre duas regiões (LEWIN, 1936, p. 54, tradução nossa). Embora, em sua proposta de uma análise topológica, Lewin não utilizasse recursos imagéticos e matriciais que a teoria dos grafos atualmente habilita, ela certamente mostra que a sistematização relacional, formalizada pela matemática, pode contribuir como formas de entendimento tanto de indivíduos quanto de grupos, bem como 
de suas interdependências.

A segunda ideia, posta no excerto de Scott (2011), de uma "sociometria clássica", recupera o trabalho de Moreno (1934). Moreno propõe uma abordagem de observação dos sistemas de relações humanas, a partir da (a) socionomia, que, enquanto ciência, considera as propriedades psicológicas de uma população e os problemas comunais que essas propriedades provocam; e (b) a sociometria, que é o estudo matemático dessas propriedades.

Moreno propõe a construção de sociogramas por seu interesse em desenvolver uma psicoterapia de grupos. Seus primeiros sociogramas apresentados, remontam um grupo de alunas em uma escola para mulheres, nos Estados Unidos, em 1933 (MARINEAU, 1989). Naquele trabalho, as escolhas preferenciais de colegas de quarto, colegas de brincadeiras e de líderes de grupo eram analisadas. Também às líderes de grupo, era perguntado quem eram as colegas com quem elas se sentiam melhor em trabalhar junto. Essas informações eram representadas em mapas que figuravam os diferentes tipos de interação entre as alunas.

Esse processo de pergunta e provocação de escolha entre pares preferenciais passa a ser conhecido como teste sociométrico. Os testes sociométricos tornam acessíveis uma estrutura referente ao grupo social. Num teste sociométrico, cada indivíduo tem a liberdade de fazer escolhas, acerca de outros. Fazer escolhas é um ato inerente à vida social. Por isso, a partir das escolhas, por diversas demandas (ou critérios de escolha) a rede dos alunos é construída. Moreno construía as redes (ou sociogramas) manualmente. Um processo trabalhoso e cuja visualização pode ser confusa (VAZ, 2009).

À época da proposta de Moreno, a Ciência das Redes nem se aproximava de como a concebemos hoje. Mais distantes ainda estavam as ferramentas computacionais que permitem a vulgarização de seus usos. Os sociogramas clássicos de Moreno (1934) podem ser pensados como grafos e como redes sociais, embora à sua época, o poder de análise dos grafos fosse limitado. Por isso, como artifício de categorização, Moreno incluía referentes representacionais de diferenciação de gênero, como vértices com formas geométricas diferentes para meninos e meninas, e de diferenciação do tipo de relação 
(arestas) com cores diferentes para atração ou repulsão.

Numa mão, isso valoriza ainda mais a inovação da proposta original de Moreno, que já buscava representar, dentro da confusão informacional que tipicamente é vista em um agrupamento humano, uma organização emergente a partir das afiliações interpessoais. Mas na outra mão, guiava as análises assumindo que a estrutura social operava em leis análogas à da gravidade, a leis da gravitação social (ALVES, 1964), talvez um pouco pelo estágio inicial de desenvolvimento das ciências ditas soft, talvez um pouco pela ausência do desenvolvimento de algoritmos que simplificassem o processo $^{2}$.

Assumir como hipótese de trabalho que o fenômeno social era regido por leis, que os grupos se organizavam análogos a uma "gravitação social", e ainda que essas leis poderiam ser conhecidas e controladas, colocava a versão inicial dos sociogramas e das análises sociométricas mais próximos do desejo positivista comteano sobre a sociologia do que das visões de sistemas sociais complexos, consideradas atualmente. Por isso, sem que se negue gênese da sociometria, a análise de redes sociais está, atualmente, distanciada daquelas posições estruturalistas clássicas.

Embora Freeman (2004), Borgatti et al. (2009) e Scott (2011) reconheçam que a utilização da Ciência das Redes nasça no berço das Ciências Naturais e da Matemática e tenha sua formalização trazida para as Ciências Sociais, os trabalhos contemporâneos com análise de redes sociais já não empenham uma busca por leis do fenômeno social. Se reconhecemos na vida social a complexidade inerente, devemos reconhecer também as frustrações da causalidade, a não-linearidade, as soluções de compromisso as retroalimentações e outras. Por isso, embora muitos dos princípios de Moreno ainda sustentem o trabalho de investigações sociométricas, suas formas de análise ganharam novos contornos e passaram a ser tratadas como redes complexas; como grafos que são referentes aos sistemas complexos sociais do cenário que se deseje analisar.

\footnotetext{
2 o primeiro computador rudimentar só estaria funcionando mais de uma década após o trabalho pioneiro de Moreno, e a popularização dos computadores pessoais só ocorreria quatro décadas depois
} 


\subsubsection{Análise de Redes Sociais em pesquisas em educação}

O uso da sociometria de Moreno é defendido por Lira, Cerqueira e Gomes (2016) que destacam o fato de que as mudanças que ocorrem na adolescência ocorrem também na esfera psicossocial e que adultos devem direcionar a atenção à integração entre pares, uma vez que ela tem papel importante na constituição do ser, para o adolescente. Por estarem em idade escolar, essa integração entre pares reverbera na vivência escolar:

este é o momento para se reconhecer um novo tempo em que, ao contrário de projetos sofisticados, técnicas como o teste sociométrico podem contribuir para a construção de um clima favorável na escola e na sala de aula. Desse modo, é possível vislumbrar um novo modo de pensar, de atuar com alunos isolados e líderes para promover a convivência.

(LIRA; CERQUEIRA; GOMES, 2016, p. 27)

A escola é o grupo social secundário de crianças e adolescentes. Por isso, é locus de desenvolvimento das práticas interpessoais. Nesse sentido, os autores reforçam que, uma vez que grupos são formados em sala de aula, por afinidade, a sociometria pode servir de suporte para professores, familiares e quaisquer outros que venham a ser, de alguma forma, responsáveis pelo desenvolvimento daqueles jovens.

Entretanto, o processo sociométrico, ou sua vertente mais contemporânea, a análise de redes sociais, demanda alguma expertise em relação às ferramentas e metodologias que dão suporte à análise de grupos em estruturação. Mas, um alento nesse potencial empecilho é encontrado nas novas formas digitais de análise, que vulgarizaram, no melhor dos sentidos, esse processo.

\section{Popularização e vantagens}

Ferramentas computacionais gratuitas e de código aberto permitiram a popularização e o acesso às ferramentas de análise das redes sociais. Isso promoveu uma supressão de grande parte do esforço, que era dispensado na produção de matrizes sociométricas de adjacências e de representações visuais dos sociogramas, dando mais tempo para que os analistas possam focar na análise, em si. 
Algumas dessas ferramentas e desses processos serão descritos no Capítulo 5, à frente. Outro efeito dessa popularização é que, agora, pesquisadores da educação, mesmo não sendo cientistas das redes, podem lançar mão das ferramentas dessa disciplina para entender melhor as estruturações dos grupos de seus sujeitos de pesquisa.

A análise de redes sociais, uma vez trazida para o âmbito da pesquisa em educação, ajuda a entender como o grupo é e como cada indivíduo se localiza no grupo. As perguntas de pesquisa que se valem da análise das redes de relações interpessoais, pairam sobre algumas noções principais: $(i)$ que as relações entre atores sociais permitem o entendimento de ações individuais, ou seja, a rede influencia seus elementos; (ii) que os atores estão imersos numa rede complexa de relações, isto é, os atores são a rede; ( $i i i)$ que a interligação entre atores promove capital social em diferentes níveis; e que (iv) fatores estruturais permitem identificar, por esse capital social, quais são os atores que mais criam laços na rede, como se dá a mediação da criação desses laços e como esses laços influenciam a rede.

Conforme salientam Melo e Regis (2015), esse capital social é um conjunto de recursos que os indivíduos criam a partir de confiança, mutualidade, pertencimento, e evoluem nas relações entre indivíduos e suas organizações. Por isso, em uma sala de aula, as trocas entre alunos, sendo produtoras e distribuidoras desse recurso, estruturam o todo. E isso se dá na evolução histórica do grupo. À medida que os alunos interagem, diariamente, um conjunto de passivos, fruto das experiências interpessoais, firma confianças e preferências. Logo, a utilização da análise de redes sociais, a partir de questões sociométricas, é um processo que revela traços desses passivos e dessa história. Eles se revelam nas declarações dos alunos, que elencam seus pares preferenciais.

\section{Redes de afinidades e equidade relacional}

Sengupta-Irving (2014) se vale de questões sociométricas e de uma representação imagética da estrutura relacional de um grupo de estudantes, para avaliar processos de colaboração em salas de aula de matemática. Os sociogramas de Sengupta-Irvin são, essencialmente, também redes sociais. Embora a abordagem da autora opte por não utilizar medidas estruturais sofisticadas, seus sociogramas analisados mostram um aspecto 
particular das redes feitas por declarações de pares, comparadas às formas tradicionais de pesquisa.

Para a autora, embora as formas mais comuns de predição de afinidades em sala de aula sejam o compartilhamento de atributos sociais e a história dos alunos, esses modos não são suficientes para explicar as relações verificadas nos sociogramas declarativos. Isso é indício de que a estrutura relacional entre alunos se forma por mais processos geradores de afinidades, que tomam forma nas escolhas diretas dos estudantes.

Figura 21 - Diagrama sociométrico dos alunos, mostrando alunos representados pelas letras de "A" a "L", com setas indicando pares de colaboradores que se nominaram mutuamente

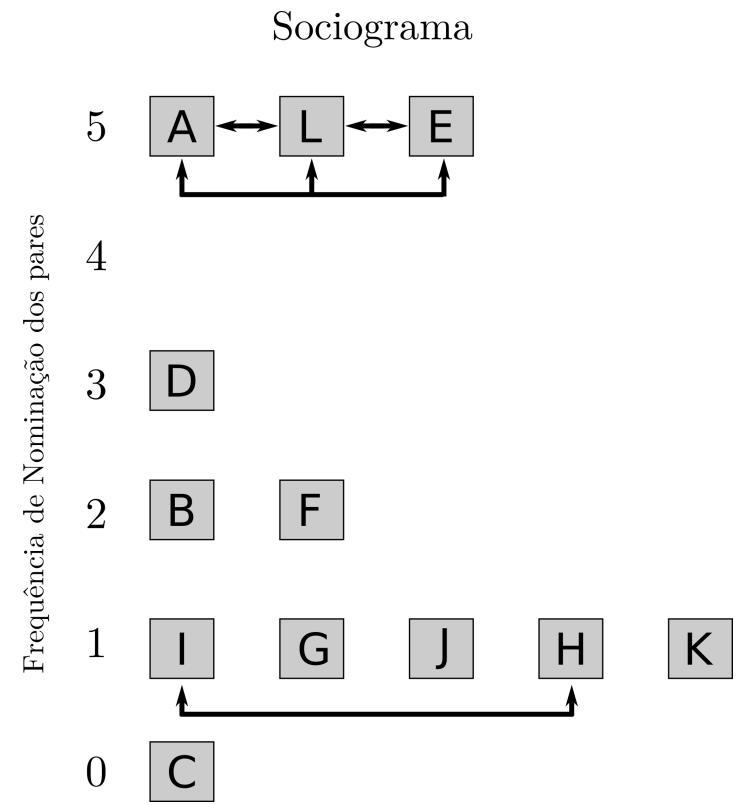

Fonte: elaboração nossa, adaptado de Sengupta-Irving (2014).

Conforme mostrado na Figura 21, que adaptamos dos resultados da autora, ao longo de um semestre há o estabelecimento uma preferência de escolha de colaboração entre certos alunos. Isso promove uma estrutura de exclusão e inclusão. Alguns pares tem seus laços fortalecidos. Essa rede de afinidades, vista nas declarações dos alunos, estruturam um aspecto da sala de aula, que a autora classifica como uma equidade relacional dos ambientes colaborativos de aprendizagem.

Apoiada por esses resultados, Sengupta-Irvin ressalta a importância do professor 
que, para além de ser uma autoridade do saber, naquele grupo, deve também ser o agente de distribuição de poder entre os alunos. Isso para diminuir a assimetria relacional e a formação de grupos que possam vir a excluir colegas. Isso promoveria uma estruturação social com mais equidade relacional, favorecendo a colaboração no processo de aprendizagem.

\section{Redes sociais e a perspectiva genética}

Utilizando uma perspectiva materialista, Saxe et al. (2009) usam uma versão de redes sociais para avaliar as relações diádicas (entre dois alunos) em sala de aula de matemática. Os autores sugerem que as ideias viajam entre membros da comunidade discente, no locus de ensino. Os autores reforçam que o compartilhamento de ideias e a formação de representações simbólicas estão imbricados com as posições sociais dos participantes da sala de aula:

todos os participantes contribuem para a prática coletiva da lição - para a estrutura emergente da lição, para as formas representacionais validadas e suas funções e para as posições sociais do professor e dos estudantes [...] as atividades dos indivíduos são, em parte, constitutivas dessa estrutura, mas também tomam forma em relação a ela e é na dinâmica entre a atividade individual e coletiva que localizamos a "viagem das ideias"

(SAXE et al., 2009, p. 208, tradução nossa)

No excerto dos autores acima, a proximidade com a presente tese é notada no uso do vocabulário característico da Teoria Geral dos Sistemas, de Bertalanffy (2010) quando mencionam o aspecto constitutivo (e não somativo) do sistema formado por díades de estudantes.

Pode-se ver ainda que, pela relação indivíduo/grupo apresentada pelos autores, há uma proximidade da visão de Saxe e colegas à dualidade agência/estrutura de Giddens (1986) e Sewell (2005), mesmo apoiados por uma outra matriz filosófica. Uma vez que os autores sugerem que o processo de viagem de ideias no grupo ocorre na dinâmica entre o ego e suas relações com os alteri, isso indica que cada díade contribui para a formação do sistema, mas também cada díade é influenciada pelo sistema.

Dentro do posicionamento de Saxe e colaboradores, a explicação para os processos de compartilhamento, ou viagem, de ideias no grupo é feita a partir da perspectiva 
genética do desenvolvimento: a ontogênese, na qual o foco está direcionado às mudanças de padrões de pensamento, no processo de desenvolvimento individual; a microgênese, processo pelo qual ocorreriam as construções de representações que tenham sentido durante a atividade; e a sociogênese, processo pelo qual a reprodução e a transformação das formas representacionais acontece entre os participantes do grupo.

Figura 22 - Sociograma de colunas, utilizado para avaliar as intensidades dos laços sociais entre pares de alunos

\section{Sociograma de influências auto-declaradas}
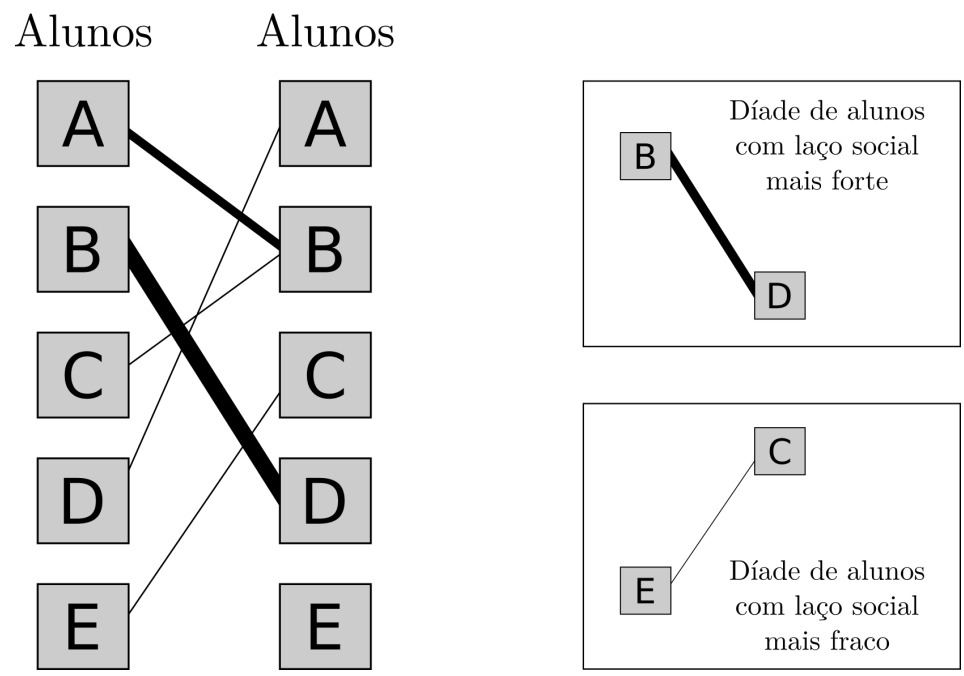

Fonte: elaboração nossa, adaptado de Saxe et al. (2009).

Embora exista, contudo, uma divergência entre o viés epistemológico de Saxe et al. (2009), que são inclinados à semiótica, quando comparados àquele de (LATOUR; HERMANDT, 2013), no qual o império da semiótica é criticado, uma vez que os referentes circulam pelas redes de significações, conectando inscrições, nos centros de cálculo e mundo, não se pode ignorar uma aproximação de ordem mais alta. Em ambas as redes, usadas como uma tecnologia do espírito, para além de uma ferramenta puramente metodológica, são empenhadas na produção de entendimentos sobre arranjos complexos situados no mundo.

A grande contribuição de Saxe e colaboradores, que tomamos para o estudo de 
caso que apresentaremos à frente, é a possibilidade de se olhar a força, ou peso, das díades formadas por estudantes em sala de aula, conforme mostrado na Figura 22, acima. Nessa abordagem, considera-se não apenas a existência de afiliações interpessoais, mas também o fato de que, a depender da força do laço social, as ideias viajarão entre indivíduos de maneira mais fluida.

Em um trabalho longitudinal de maior envergadura, Saxe e Esmonde (2012) avaliam, ao longo de 3 décadas, uma aldeia papuásia, que recebeu colonização ocidental e que, por isso, teve ao longo dos anos seu sistema de contagem alterado. De maneira semelhante à viagem de ideias em sala de aula, Saxe e Esmonde observam a organização social da aldeia como uma rede complexa, permeável, que sofre influências de agentes externos, conforme representado na Figura 23, à frente.

Figura 23 - Representação da influência das instituições ocidentais no complexo social dos comunitários de uma vila papuásia
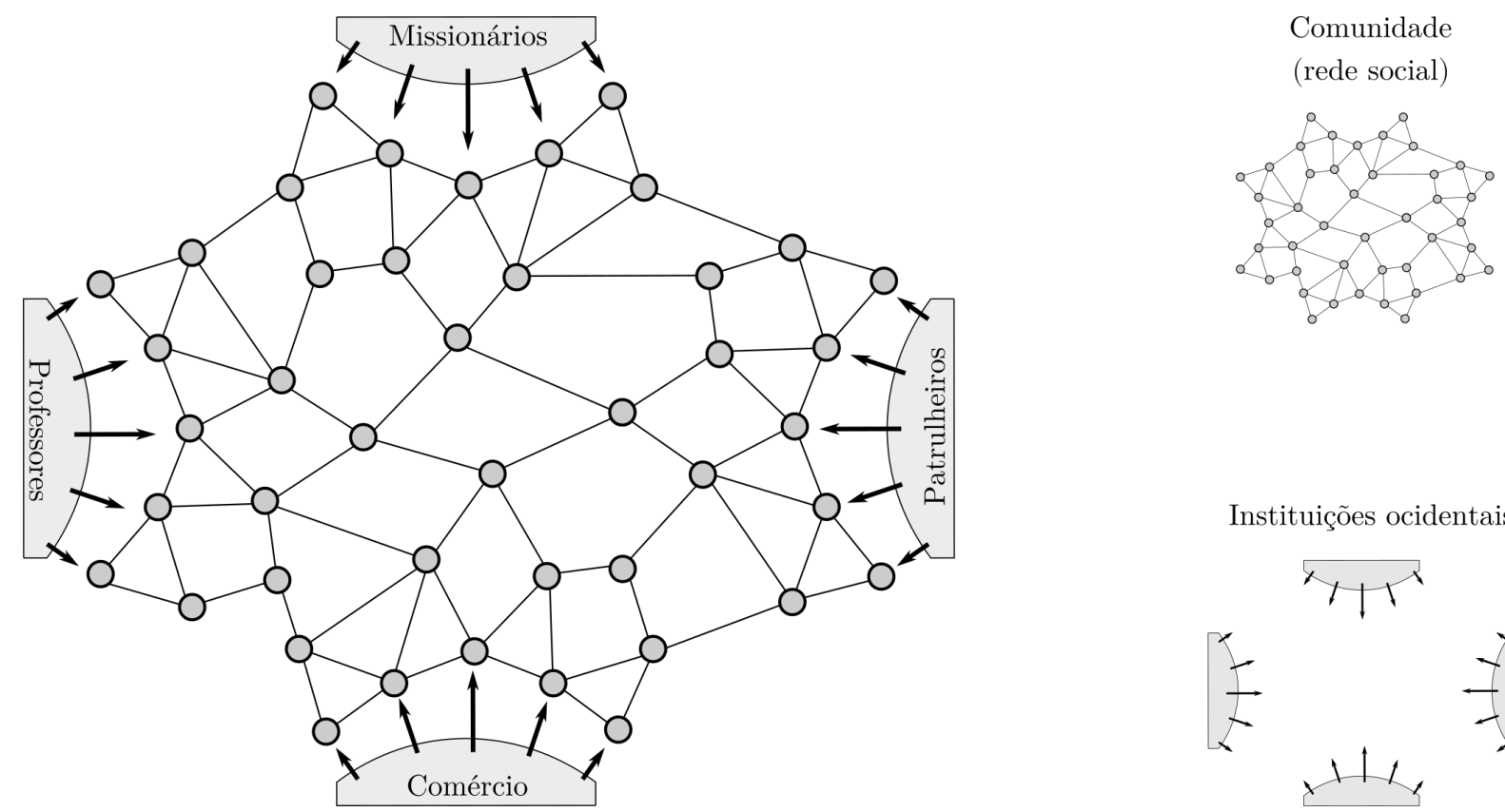

Fonte: elaboração nossa, adaptado de Saxe e Esmonde (2012).

Da rede dos comunitários emergiu, em sua história evolutiva, um sistema de contagem que utilizava, além dos dígitos, partes do cotovelo, ombro e rosto, totalizando 27 unidades. Mas, pela sobreposição das culturas locais e ocidentais, as diferentes pressões 
externas, sofridas pela rede, promoveram uma mudança de forma e de função do referente representacional numérico.

Esse processo de transmissão (ou broadcasting) de ideias, mostrado por Saxe e Esmonde, sugere a rede como sistema complexo, estruturado, que pode sofrer emergências de dentro pra fora: o sistema original de contagem utilizado, é produto do desenvolvimento da linguagem daquele povoado. Mas também de fora para dentro: a influência da chegada das instituições ocidentais e a interação das aldeias, antes isoladas, com comerciantes, missionários e outras, amplia o número de graus de liberdade daquele conjunto constitutivo, aumentando a complexidade da organização social e dos produtos culturais do grupo.

Esses trabalhos são influenciadores desta tese, pois deles tomamos emprestadas a característica de organizadora do pensamentos, na qual a complexidade é pensada e avaliada de maneira reticulada para explicar a dinâmica de processos desenvolvimento culturais e sociais (SAXE; ESMONDE, 2012). Mas também a característica metarrepresentacional das redes, na qual seu desenho explícito é formalizador do método de estudo (SAXE et al., 2009). Duas características que corroboram a multiplicidade do reticular, proposta por Musso (2013).

\section{Redes sociais não-presenciais na pesquisa em educação em ciências}

Se as formas de construção de redes sociais acima se valem de declarações de participantes (SAXE et al., 2009; SENGUPTA-IRVING, 2014) ou observações situacionais (SAXE; ESMONDE, 2012), há a possibilidade de se construir e analisar redes sociais por outras relações interpessoais, que não as presenciais. As informações podem ser obtidas a

partir de trocas virtuais. É o que pode ser visto no trabalho de Martınez et al. (2003), que avaliaram a rede social de um grupo de alunos, sobrepondo os dados sociométricos e registros de atividades em logs de computadores em um servidor, observando processos de colaboração entre alunos em uma universidade semi-presencial.

Outro trabalho de construção de redes sociais não-presenciais é visto em Pucinelli e Giordan (2017), que analisam a rede social formada por um grupo de 11 professores num curso de formação, tomando-se como relação sociométrica as interações em um fórum de 
discussão. Os resultados dos autores (Fig. 24) mostram que a rede é altamente centralizada no tutor, algo que enfraquece a estrutura, pois com a saída do tutor, possivelmente o sistema entraria em colapso. Esse estudo nos deixa duas mensagens. A primeira delas é que o desejo que se tem ao propor um fórum entre alunos é o desdobramento de um debate que não se direcione ao professor ou ao tutor. Busca-se por um sistema autônomo de troca de informações, embora seu estabelecimento não seja fácil de se obter.

Figura 24 - Rede social, direcionada, formadas por interações em um fórum de discussão online

\section{Forum}

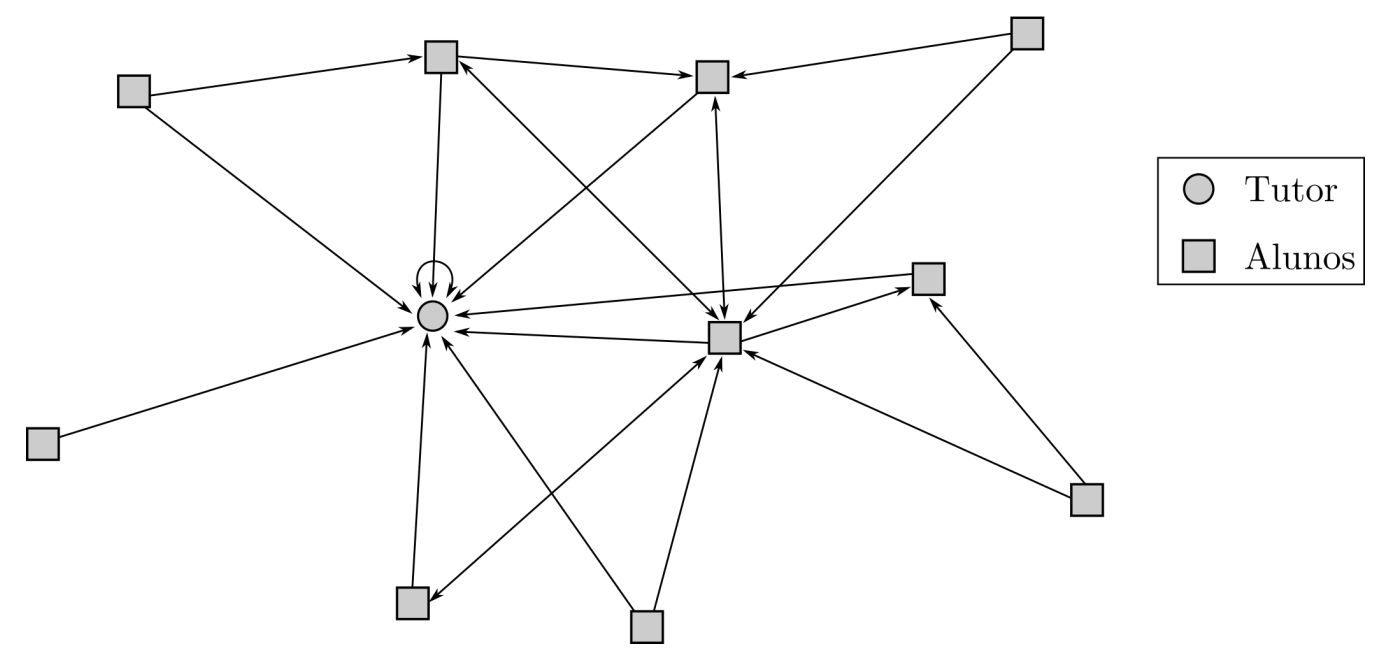

Fonte: elaboração nossa, adaptado de Pucinelli e Giordan (2017).

A segunda mensagem é que, do ponto de vista da análise da rede social, por sua própria posição institucionalizada, o professor tenderá a ser um elemento estrutural assimétrico em relação aos alunos. Por isso, pode ser mais interessante construir e analisar uma rede social que não inclua o professor. Essa característica confirma o que apresentamos na Seção 1.3 do Capítulo 1, quando declaramos, na Figura 3, que olharemos apenas dois dos três vértices do triângulo de Chevallard (1991). Não que a posição estrutural do professor deva ser ignorada nas redes sociais que emergem das salas de aula. Mas sim porque essa posição estrutural, além de ser institucionalizada, imprime um papel tão central no processo, tal que promoveria redes fortemente centralizadas, como as de Pucinelli e Giordan (2017). 


\subsubsection{Considerações finais: busca por relações entre redes}

Apresentamos, neste capítulo, dois domínios potenciais de observação da sala de aula, via análise de redes. Em um deles, as redes semânticas, formadas por associação de palavras e que, quando avaliadas para um coletivo, se remetem às representações sociais do grupo. No outro, as redes sociais, formadas por associações entre pessoas (entre alunos, no nosso contexto de pesquisa) indicam a estrutura emergente do grupo.

Cada uma delas pode ser, per si, forma única de estudo de objetos de pesquisa em educação, conforme mostramos. No entanto, nesta tese nos propomos a observar complexidades em escalas próximas; buscamos a produção de uma análise que se situa na sobreposição de complexidades interpessoais e representacionais. Mas isso significa trabalhar com emergências em dois domínios.

As abordagens de ponta que se esforçam em trazer a ciência das redes para a pesquisa em educação, parecem reconhecer a complexidade da sala de aula e, por isso, apontam para a necessidade de métodos adequados para análise objetiva em mais de um nível de complexidade. Entretanto, há um conjunto de desafios a serem superados, tal que as análises multi-nível ou multi-escala de redes seja implementada na pesquisa da sala de aula. São desafios tanto de ordem teórica, algo que demanda bricolagens, para termos capacidade de interpretação em diferentes aspectos da paisagem, conforme discutimos no Cap. 1, quanto de ordem filosófica, pois as redes não são apenas método nesta tese, mas essencialmente a nossa forma de olhar para a sala de aula. São também desafios de cunho metodológico, visto que os modelos dos sistemas complexos dependem, em parte, da estrutura do próprio sistema e, em parte, das decisões de pesquisa, que definem como queremos olhar o sistema e como queremos delimitar suas fronteiras.

Nesta tese, não estamos mimicando métodos historicamente solidificados de observação da complexidade da sala de aula. Em parte, nosso trabalho foi exatamente o de desenvolver tais métodos. Buscamos elaborar formas de sobrepor as redes de ideias (semânticas) e as redes de pessoas (sociais), selecionando características que nos ajudassem a fazer sentido do sistema. Uma vez selecionadas essas características e desenvolvido o 
protocolo de análise, empenhamos um trabalho empírico, situado em sala de aula. No Capítulo 5, a seguir, apresentamos esse estudo empírico e nossa proposta. Utilizamos a oportunidade também para detalharmos nossa abordagem metodológica desenvolvida. Por ela pudemos explorar não apenas as representações sociais ou as estruturas interpessoais mas, principalmente, como essas duas "camadas de complexidade" se relacionam no decorrer dos processos de uma sala de aula. 


\section{Estudo de caso: redes e complexidade de}

\section{uma sala de aula}

A ciência não é uma substituta do senso comum, mas uma extensão dele.

Willard V. O. Quine

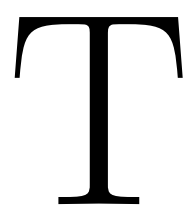

EMOs defendido que organizações estruturais emergem em sistemas nos quais unidades elementares estão em constante interação (Cap. 2). Essa é uma característica inerente aos sistemas que vimos nominando por complexos. São as organizações emergentes nesses sistemas que permitem estabilidades. E uma vez que estabilidades surgem, padrões podem ser identificados no sistema. Para que tais padrões emergentes sejam investigados, é necessário que se tenha métodos adequados para que possamos produzir inferências a partir de características objetivas, coletadas do mundo, mas também, caminhos que permitam a representação formal desses padrões .

Neste capítulo final, apresentamos um estudo de caso $^{1}$, situado numa sala de aula. Nesse estudo de caso, as redes foram construídas a partir de dados empíricos vindos tanto do domínio social quanto do domínio representacional e uma busca por relações entre esses dois domínios foi empreendida. O método de formalização dos padrões é sua modelagem na forma de grafos, conforme apresentamos no Capítulo 2 e atinentes ao panorama de pesquisa no cenário global, discutido no Capítulo 3.

Para além de meramente um método, as redes aqui serviram também como forma de se conceber as emergências estruturais do grupo de alunos da sala de aula e como forma de se avaliar o compartilhamento de ideias entre temas referentes à vida cotidiana dos alunos, operando nas duas dimensões mostradas no Capítulo 4. Mas para procedermos nossa

${ }^{1}$ este capítulo é uma versão ampla do trabalho publicado na revista Education Sciences (RODRIGUES; PIETROCOLA, 2020) 
análise, utilizamos um acoplamento de perspectivas teóricas, que nos foram complementares, conforme defendemos no Capítulo 1. Dessa forma, neste capítulo recuperaremos algumas das bases apresentadas anteriormente, posicionando-as em uma abordagem empírica de pesquisa, conforme mostraremos a seguir.

\subsection{Introdução do estudo de caso}

A complexidade é inerente a sistemas reais. Embora saibamos que não exista uma definição formal, largamente aceita, sobre o que seria um sistema complexo, podemos retomar à proposta de Mitchell (2006), para quem, informalmente, as redes de elementos em interação, que não possuem controle central e que exibem comportamentos emergentes, são sinônimos de sistemas complexos. A ciência das redes fornece ferramentas para que nos refiramos aos sistemas complexos, bem como para que os representemos formalmente.

Em geral, as redes podem ser concebidas como sendo um conjunto de elementos e de conexões entre eles. Tais conjuntos elementos/relações podem se referir a basicamente qualquer grupo ou unidades e suas relações existentes, ou a atores e suas interações, desde que se tenha formas objetivas de reconhecimento dos nós ou vértices da rede e dos links ou arestas, ou conexões, na rede. As redes podem ser formalmente representadas como conjuntos matemáticos, como matrizes ou como imagens, sempre operando sob a teoria dos grafos (BARABÁSI, 2003; CHRISTAKIS; FOWLER, 2007).

Ao tomarmos essas noções para pensarmos uma sala de aula, suas estruturas emergentes podem ser vistas como redes de inúmeros jeitos. No domínio interpessoal, a abordagem de redes pode ser utilizada considerando-se cada aluno como um vértice e cada relação aluno/aluno como uma aresta, na perspectiva das redes sociais (SCOTT, 2011). Nessa perspectiva, as redes sociais vêm sendo utilizadas para o entendimento de aspectos da sala de aula, como a análise da formação de lideranças (FARMER; RODKIN, 1996) e as estruturas de colaboração (SENGUPTA-IRVING, 2014).

Embora as redes, utilizadas estritamente no domínio social, possam ser uma fonte de informação rica acerca do reino interpessoal, elas não levam em conta o domínio do 
pensamento. Redes sociais clarificam as posições estruturais de cada aluno, como essas posições operam no grupo, quais são as sub-comunidades formadas e mesmo quais são os pares mais fortemente atados na sala de aula. Mas elas não dizem respeito às ideias compartilhadas pelos alunos.

Como estamos interessados em investigar não apenas as redes no domínio interpessoal, mas também ideias que os estudantes compartilham e como, isso exige que abordemos o outro reino no qual as redes são utilizadas para explorar e entender o pensamento compartilhado. Nesse sentido, a abordagem de redes destinada à dimensão do pensamento, na pesquisa em educação científica, já vem sendo utilizada numa sorte de projetos. Desde redes proposicionais individuais dos alunos, a partir de mapas conceituais (CICUTO; CORREIA, 2012) até a análise das estruturas de redes semânticas de alunos, feitas por associação de palavras (RODRIGUES; CAMILETTI, 2018) e mesmo para análise de discurso oral (TEIXEIRA et al., 2010).

Neste estudo de caso, nosso propósito é usar a abordagem de redes para investigar estruturas emergentes, tanto do domínio social quanto do domínio semântico, numa sala de aula de Física, para podermos explorar relações entre a força dos laços interpessoais e o compartilhamento de ideias.

\subsection{O sistema didático e os dois domínios investigados}

O sistema didático de Chevallard (1991) é pensado considerando-se três polos fundamentais: o estudante, o professor e o saber; e como esses polos se relacionam na transposição didática. Conforme detalhado no Capítulo 1, por transposição, entende-se a série de transformações que o conhecimento sofre ao ser trazido de seus contextos profissionais de produção, quando é um saber sábio, para o processo de ensino, no qual é um saber a ser ensinado.

No sentido dado por Chevallard, o conhecimento a ser ensinado em sala de aula não é uma versão simplificada ou facilitada do conhecimento profissional. Por suas diferenças em relação às formas de validação e aos propósitos, o conhecimento ensinado se vale de 
um posicionamento epistêmico diferente. Nesse novo nicho epistêmico, o conhecimento não se valida pela produção de um saber profissional parcial, mas sim pela produção de um saber escolar (BROCKINGTON; PIETROCOLA, 2005).

No entanto, uma transposição de segunda ordem ocorre nesse processo. O conhecimento ensinado, que é trazido aos alunos a partir das instâncias institucionais escolares, já tendo sido trazido à escola a partir das instâncias institucionais da produção científica, permeia uma instância que não é institucionalizada: a vida dos alunos. Nessa outra instância, aquilo que os alunos produzem como consenso acerca do conhecimento ensinado, bem como aquilo que o conhecimento molda na vida dos alunos, são representações socialmente construídas (MOSCOVICI, 1978).

Enquanto as instâncias institucionais produzem e validam o conhecimento dentro de um universo reificado, a circulação do conhecimento entre os alunos se dá num universo consensual. Embora o universo consensual seja menos organizado que o universo reificado, podemos explorá-lo nas representações sociais produzidas, apesar de sua estrutura intrincada. Isso porque, mesmo que as representações sejam muito dinâmicas, a estabilidade dos núcleos figurativos pode emergir, permitindo sua detecção. Essa aparente contradição, típica de qualquer sistema complexo, é também tomada como inerente às representações, particularmente quando abordada estruturalmente (ABRIC, 1993). Nessa abordagem estrutural, as redes complexas permitem a formalização e uma metarrepresentação dessas estruturas (RODRIGUES; BORGES; PIETROCOLA, 2019). Lidar com as representações sociais como sendo redes complexas de lexemas tem se mostrado uma abordagem não só válida, como profícua.

Então tem-se, de um lado, as redes que são referentes das representações sociais. Estas são intimamente ligadas às transformações que o conhecimento sofre, quando transposto do universo reificado e, após se tornar um conhecimento ensinado, se sobrepõem ao universo consensual dos alunos. Mas isso dirige o foco exclusivamente à representação. Mesmo não se tratando das cognições dos indivíduos, mas sim de um coletivo, o elemento do pensamento (compartilhado) é o foco de observação. A atenção está voltada ao psicossocial. Mas isso não se dissocia do elemento estritamente social. Por isso, de outro lado, tem-se o 
fato de que as ideias que circulam e que permitem a emergência das representações, se dão no âmbito social, estritamente falando.

A importância desse fator social é vista no fato do grupo dos alunos formar, sozinho, um outro vértice do sistema didático. Não se nega a interdependência desses dois vértices. Sua estruturação depende de relações interpessoais que moldam e que são moldadas pelas representações. E isso exige que tenhamos a atenção voltada também à estruturação interpessoal da sala de aula. Por isso, os sociogramas de Moreno (1934), que em sua versão contemporânea deixam o modelo de uma "gravitação social" e passam a ser trabalhados dentro das formalizações da teoria dos grafos, ganhando forma de redes (complexas) sociais (FREEMAN, 2004), permitem a análise desse outro domínio.

A análise de redes sociais continua sendo associada, metaforicamente, a sistemas físicos nos quais qualquer relação diádica pode ser avaliada como sendo uma rede. Ou associadas a estruturas químicas nas quais as ligações sociais são pensadas como ligações covalentes (BORGATTI et al., 2009). Em salas de aula, as relações diádicas podem ser formadas a partir de qualquer troca entre alunos, seja não-presencial (MARTINEZ et al., 2003; PUCINELLI; GIORDAN, 2017), seja por nomeação direta (SENGUPTA-IRVING, 2014). Apesar das possíveis objeções que podem ser feitas às tentativas de importação de lógicas das ciências naturais às análises de contextos sociais (com as quais concordamos), os paralelos com a física e a química aqui, diferentes de uma proposição de experimentação clássica e de uma busca por lei elementares do social, funcionam como artefatos úteis à compreensão dos arranjos complexos da sala de aula.

Como as relações interpessoais e representações sociais emergem, ambas, como organizações complexas, as redes são a abordagem para que lidemos com elas. Primeiro, porque as redes são utilizadas como metáforas, artifício do pensamento para alguma compreensão sobre essas complexidades, ou seja, como tecnologia do espírito. Depois, as redes como método servem para que essas complexidades sejam exploradas. As redes são, então, tanto tecnologia do espírito quanto matriz técnica (MUSSO, 2013). Pela articulação das redes sociais e semânticas, é possível explorarmos também relações na aresta estudantes $\leftrightarrow$ conhecimento do sistema didático. A Figura 25, a seguir, mostra 
esquematicamente onde se posiciona o interesse desse estudo de caso e como as redes semânticas e as redes sociais tomam lugares no sistema didático.

Figura 25 - Representação esquemática heurística do sistema didático e da transposição didática, promotora de pontes entre o universo reificado e o universo consensual. À direita, as redes complexas no âmbito semântico e no âmbito social, posicionadas no sistema didático e a busca por relações entre esses dois âmbitos

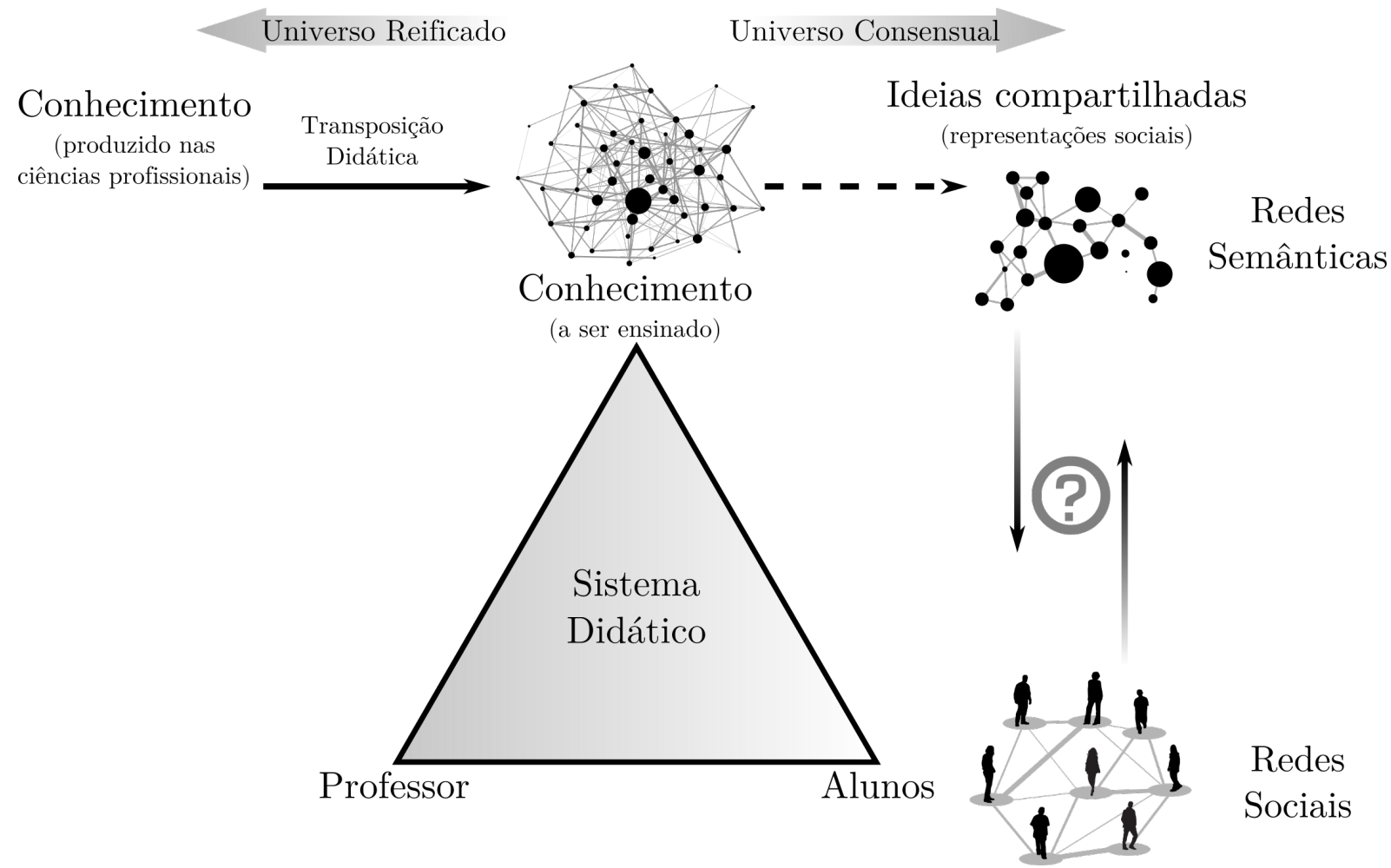

Fonte: elaboração nossa, adaptado de Rodrigues e Pietrocola (2020).

Vê-se na representação esquemática acima, que o vértice "Professor" do sistema didático, não é ativado neste estudo. Isso porque se considerarmos o papel do professor, que opera a primeira transposição (Fig. 25), e que desempenha função central no processo de ensino /aprendizagem, a rede será centrada dos alunos para essa centralidade do docente, semelhante ao que mostraram Pucinelli e Giordan (2017). O professor é tão relevante no processo que ocupa, sozinho, um dos vértices chevallarianos.

Embora possa ser valioso explorar o papel do professor nas redes, incluindo como as instâncias institucionais exerceriam ou não um controle sobre as complexidades da sala de aula, neste estudo de caso, estamos interessados em outro processo: aquele pelo qual o 
conhecimento se espalha entre alunos e no qual os consensos são formados. E, mais ainda, em como as díades de alunos se relacionam a esse processo representacional.

Observa-se na Figura 25, que esse processo, diferente da transposição de primeira ordem, não é garantido e, por isso, está representado por uma seta com linha tracejada. A questão que permanece, então, se refere ao papel dos laços sociais no processo de compartilhamento de ideias. Nesse sentido, tomamos emprestada a proposta de Saxe et al. (2009), que utilizam sociogramas construídos por colegas de mesa, em aulas de matemática, e avaliam a intensidade da relação entre os pares para analisar o processo de viagem de ideias no grupo.

Saxe e colegas partem da abordagem genética do desenvolvimento (VYGOTSKY, 1986) e utilizam as redes para avaliar a ontogênese, que se refere às mudanças de padrões de pensamento dos indivíduos, no tempo; a microgênese, pela qual representações significantes se desenvolvem no decorrer das relações interpessoais; e a sociogênese, pela qual os padrões de representação se ajustam, de modo a promover a comunicação entre participantes do grupo.

Embora, neste trabalho, nós não estejamos trabalhando dentro dos quadros da perspectiva genética, há que se declarar a influência da proposta de Saxe e colegas em nosso procedimento de análise, especialmente sobre a inclusão da força dos laços par a par como variável relevante ao processo de produção e comunicação de representações, conforme mostraremos a seguir.

\subsection{Material e métodos}

\subsubsection{Contexto do estudo}

A pesquisa se dá em uma escola pública da cidade de São Paulo, SP. A unidade escolar tem entre 800 e 850 alunos regularmente matriculados ${ }^{2}$. O estudo se desenvolveu no acompanhamento de uma turma regular da segunda série do Ensino Médio, composta por

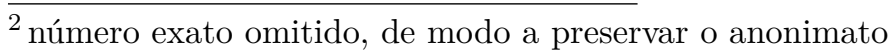


36 alunos regularmente matriculados, sendo 23 do sexo masculino e 13 do sexo feminino, durante o primeiro semestre do ano de 2018.

O contexto escolar do desenvolvimento da pesquisa se dá numa escola cujas características retratam de maneira clara os contrastes socioeconômicos que a larga escala brasileira tem. O prédio escolar se situa em um bairro que se pode chamar nobre, embora seja cercado por bairros periféricos, locais de moradores de baixa renda. Esse espectro socioeconômico é vivenciado pelos alunos diariamente.

Em grande parte, os estudantes chegam à escola caminhando, desde de suas casas até o local de estudos. Nesse trajeto, a cada esquina se tem uma mudança de paisagem arquitetônica e urbanística. Esse degradê social e econômico é também um degradê de oportunidades. Em meio a uma realidade muitas vezes adversa e encarando constantemente o contraste, os estudantes, nossos sujeitos de pesquisa deste estudo, lutavam para obterem sua escolarização. À medida que eu, na condição de pesquisador, fui convivendo com o grupo e entendendo com alguma clareza esse contraste, vi necessidade de inclusão de elementos representacionais referentes a temas que extrapolassem os muros da escola, que serão declarados mais à frente.

O contato do pesquisador com a unidade escolar se deu anteriormente à coleta de dados deste estudo. Naquele semestre, eu atuava como monitor em uma disciplina de estágio da licenciatura em Física em uma universidade pública do estado de São Paulo. Por isso, visitava a unidade escolar com frequência, fosse para resolver questões burocráticas com a direção da unidade e com a coordenação escolar, fosse para acompanhar regularmente os alunos da licenciatura em suas atividades de estágio. Como consequência dessa constante interação com a escola, pude me aproximar tanto do professor de Física daquele Ensino Médio, quanto de algumas turmas, com quem eu costumava estar junto.

O professor era um jovem licenciado em Física por uma universidade pública, e apresentava uma relação compreensiva e amigável com os alunos, o que favoreceu a aceitação para que o estudo fosse procedido em uma das turmas. Por isso, durante nove semanas, acompanhei um total de dez aulas de Física desse professor, na turma em questão. No período do estudo naquela sala de aula, o professor discutia com os alunos os processos de 
transferência de Calor. Durante a primeira semana, tendo previamente obtido a permissão do professor, o pesquisador se apresentou à turma e apresentou brevemente o processo de pesquisa que desenvolveria com os alunos. Nessa mesma ocasião, cada aluno recebeu um formulário de autorização, que deveriam devolver assinado pelos responsáveis, de modo a dar ciência e dar aceite à pesquisa. Após o retorno dos formulários, os dados começaram a ser coletados. No presente estudo, apresentamos resultados das redes construídas entre a terceira e a quarta aulas de acompanhamento.

\subsubsection{Delineamento metodológico}

O design de pesquisa deste estudo, segue a proposta de um estudo de caso exploratório e explanatório (YIN, 1981). Isso porque nossa investigação empírica lida com um fenômeno contemporâneo, situado no contexto da vida real e ainda tratamos de uma investigação na qual as fronteiras entre o fenômeno e o contexto não são claramente evidentes. Para isso, lidamos com múltiplas fontes de evidências, explorando o domínio representacional, o social e as relações de intermédio.

Na condição de estudo de caso exploratório e explanatório, o presente estudo funciona como um processo informativo que deve ser endereçado a um ambiente e contexto específicos. Se lidamos com sistemas complexos, devemos estar sempre atentos ao fato de não teremos causalidades preditivas nem acontecimentos definidos a priori (KURTZ; SNOWDEN, 2003). Nossas redes não estão a serviço de generalizações ou de suposições determinísticas. Ao contrário, a investigação da sala de aula a partir de suas redes emergentes semânticas e sociais, bem como a exploração das relações entre essas complexidades deve ser utilizada para que se faça sentido de processos sutis de estruturação. Por isso, mesmo que cada uma das redes sempre seja um instrumento de referência a uma estruturação passada, ainda assim, elas nos ajudam a interpretar tal processo, nos dando pistas para teorização dos acontecimentos ocorridos nas relações didáticas. 


\section{As redes semânticas}

A coleta de dados para as redes semânticas se valeu da Técnica de Associação Livre de Palavras (TALP) a partir de termos evocados livremente (GIACOMO, 1980). A técnica consiste em pedir aos sujeitos de pesquisa que digam (ou que escrevam) as primeiras palavras que lhes vêm à mente a respeito de um certo termo indutor que nós lhes oferecemos:

"escreva as cinco primeiras palavras que lhe vêm à mente quando eu digo ..."

De posse das palavras evocadas, uma rede é construída tendo como vértices as palavras e como arestas uma relação de similaridade entre palavras. Embora os usos das redes de palavras em contextos da semântica possam variar, a ideia central é sempre a de usar a associação entre os lexemas (palavras estruturantes) para produzir inferências sobre similaridades, significados ou sobre aspectos estruturais da rede. A similaridade pode ser obtida de outra forma, como, por exemplo, o aspecto fonológico das palavras (STELLA; KENETT, 2019). Outra forma de se obter uma associação entre palavras é proceder evocações e gerar arestas a partir da similaridade, conforme a proposta clássica de Giacomo (1980), porém também tomar para os termos uma dada valência emocional (positiva, negativa ou neutra) e, com isso, gerar a rede de palavras, diferenciando as relações entre termos a partir dessas valências (STELLA, 2020).

Neste estudo de caso, a similaridade entre palavras é produzida a partir das coocorrências dos termos, evocados por diferentes participantes. Mesmo que trabalhos de análise de big data venham firmando o uso de três palavras evocadas para cada termo indutor (DEYNE; NAVARRO; STORMS, 2013), optamos por solicitar aos alunos que evocassem cinco palavras para cada termo indutor, provendo assim mais oportunidades para que expressassem suas palavras relacionadas e favorecendo as nuances da representação social.

Os termos indutores escolhidos se referiam a objetos representacionais, variando de temas internos à sala de aula, ligados ao desenvolvimento do conteúdo, até termos que se referissem a uma projeção dos próprios estudantes em suas vidas pós-escola. Foram eles: 
( $i$ ) Calor: era o tema que o professor estava trabalhando com os alunos durantes as semanas de coleta de dados e, por isso, seria um assunto vívido àqueles alunos;

(ii) Física: que era a disciplina escolar dentro da qual o estudo foi procedido, configurando ainda um tema intra-escolar para os alunos;

(iii) Ciência: seus sentidos podem ser pontes entre os mundos intra e extra-escolares. Como a ciência é elemento presente na mídia, mas também nas salas de aula, palavras evocadas podem indicar representações nas pontes entre os dois mundos;

(iv) Escola: palavras evocadas para esse termo indutor eliciam pensamentos sobre a vida diária dos estudantes mas, ao mesmo tempo, podem acomodar sentimentos expressos acerca da realidade escolar e acerca dos contrastes que os alunos experienciam diariamente;

$(v)$ Futuro: esse deveria ser um termo indutor mais distante da escola, seja no espaço, seja no tempo. Entretanto, o aspecto prospectivo em relação ao futuro e suas palavras evocadas podem mostrar representações de possíveis trajetórias de vida nas quais os estudantes imaginam a si mesmos.

Na ocasião da coleta das evocações, todos os presentes (22/36 alunos) responderam ao formulário dado (Apêndice A). As palavras evocadas foram lematizadas, buscando-se agrupar suas formas flexionadas. Os dados foram convertidos em um arquivo .CSV e foram, então importados para o IRaMuTeQ ${ }^{3}$ (RATINAUD, 2008) que é uma interface gratuita e trabalha em conjunto com a plataforma gratuita e de código aberto para análises estatísticas R ( R - Core Team, 2008).

O índice de similaridade para as co-ocorrências entre palavras foi o algoritmo de Russel (RUSSELL; RAO, 1940) que permite o cálculo de um valor numérico para a similaridade, utilizado para a construção de uma rede de palavras não direcionada. Utilizando-se o algoritmo de Russel, a dependência direcional das evocações não interfere na rede, nem tampouco a ordem de evocação. O cômputo da similaridade foi feito para

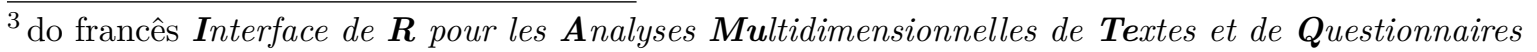


todos os pares de lexemas evocados, conforme detalhamos na Figura 26 à frente.

Cinco matrizes de similaridades foram calculadas para os cinco termos indutores, considerando todos os pares possíveis de lexemas. Então, as matrizes de similaridade foram convertidas em novos arquivos do tipo .CSV e foram exportadas do IRaMuTeQ para serem pós-processadas no R, com o pacote específico de análise de redes complexas Igraph (CSARDI; NEPUSZ, 2006).

Figura 26 - Detalhamento da construção da rede semântica, a partir de co-ocorrência de palavras evocadas

(A) Evocações dos alunos

$\begin{array}{rlll}\text { aluna(o) } & \text { evoc_01 } & \text { evoc_02 } & \text { evoc_03 } \\ \text { Ana } & \text { gato } & \text { cão } & \text { castor } \\ \text { João } & \text { cão } & \text { gato } & \text { papagaio } \\ \text { Maria } & \text { rato } & \text { castor } & \text { cão } \\ \text { Paulo } & \text { gato } & \text { cão } & \text { rato }\end{array}$

(D) e.g. de similaridade entre as evocações "cão" e "gato"

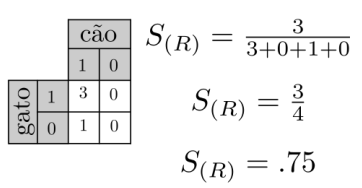

(B) Matriz de ocorrências

\begin{tabular}{|c|c|c|c|c|c|}
\hline aluna(o) & $x^{\circ}$ & 8 & $c^{\circ}$ & $<^{\infty}$ & $e^{2}$ \\
\hline Ana & 1 & 1 & 1 & 0 & 0 \\
\hline João & 1 & 1 & 0 & 0 & 1 \\
\hline Maria & 1 & 0 & 1 & 1 & 0 \\
\hline Paulo & 1 & 1 & 0 & 1 & 0 \\
\hline
\end{tabular}

(E) Matriz de similaridades

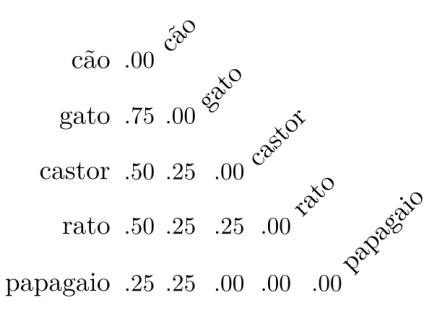

(C) Matrix de contingências $2 \times 2$

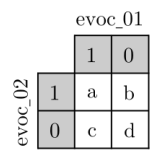

Índice de similaridade de Russel$$
S_{(R)}=\frac{a}{a+b+c+d}
$$

(F) Rede de palavras por índice de co-ocorrências

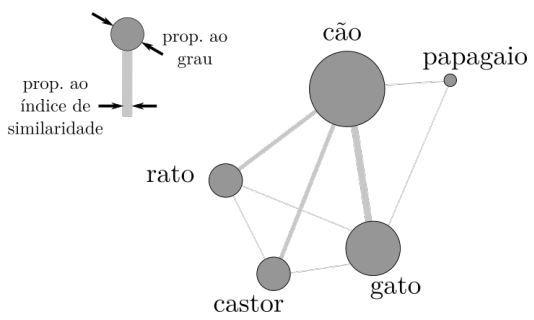

Fonte: elaboração nossa, adaptado de Rodrigues, Borges e Pietrocola (2019) e de Rodrigues e Pietrocola (2020).

Na Figura 26, tem-se o exemplo de uma suposta evocação livre de três palavras feita por quatro alunos. O processo de construção da rede toma como dado cru as palavras evocadas, em uma matriz de evocações (Fig. 26, A). Então, uma vez lematizadas, todas as evocações são ordenadas por frequência e uma matriz booleana de ocorrências, contendo 0 para não ocorre e 1 para ocorre, é construída (Fig. 26, B). Daí, para cada par de palavras, uma matriz de contingências $A_{i j}$ ( $i$ para linhas e $j$ para colunas), de tamanho $2 \times 2$ é construída.

Nessa matriz, a posição $A_{11}$ representa o número de vezes que as duas palavras 
co-ocorrem (Fig. 26, C, elemento a); a posição $A_{21}$ contem o número de vezes que a palavra 1 ocorre sem que a palavra 2 co-ocorra (Fig. 26, C, elemento c); a posição $A_{12}$ indica o número de vezes que a palavra 2 ocorre sem que a palavra 1 co-ocorra (Fig. 26, C, elemento b); e, por fim, a posição $A_{22}$ tendo o número de vezes que nenhuma das duas palavras ocorre (Fig. 26, C, elemento d).

Então, o índice de similaridade de Russel é calculado:

$$
S_{(R)}=\frac{A_{11}}{A_{11}+A_{12}+A_{21}+A_{22}}
$$

Um exemplo da similaridade entre "cão" e "gato" é dado na Figura 26, D. O cálculo do índice de similaridade é feito para todos os possíveis pares de palavras evocadas. De posse de todas os valores de similaridade dois a dois, uma matriz de similaridades é construída (Fig. 26, E). Essa matriz de similaridades é utilizada como a matriz de adjacências que originará a rede. A rede de palavras então é construída tendo o diâmetro visual de cada vértice sendo proporcional à frequência de evocação e tendo a espessura de cada aresta sendo proporcional à similaridade que relaciona duas palavras (Fig. 26, F).

\section{As redes sociais}

Para a construção das redes sociais, utilizamos a proposta do teste sociométrico, feito a partir de escolhas livres de pares preferenciais (LIRA; CERQUEIRA; GOMES, 2016). O teste consiste em pedir que os alunos declarem quem são seus pares preferidos ou quem são os colegas a quem se sentem mais conectados, em diferentes situações. Embora a sociometria clássica inclua a possibilidade de levantar, dos alunos, quem seriam os pares como quem eles se sentiam desconectados ou ainda quem seriam os colegas com quem eles se sentiam em oposição, optamos por não incluir critérios disruptivos. Isso para evitar que os processos da pesquisa, por si só, pudessem fomentar rupturas em sala de aula.

O instrumento de coleta dos dados sociométricos foi composto de oito itens, nos quais os respondentes indicariam suas afiliações explicitas, como $(i)$ "Quem são os colegas com quem você costuma andar no intervalo?" ou afiliações tácitas do tipo (ii) "Quem são 
os colegas que gostam do mesmo estilo musical que você? Os critérios então, discutidos e definidos a partir de debates em reuniões de grupo de pesquisa, buscavam cobrir fatores diretos e indiretos. Nos diretos, as afiliações declaradas se referiam àquilo que os alunos tinham como prática no dia a dia deles. Já os indiretos, indicavam relações nas quais as afiliações interpessoais pudessem ocorrer por uma comunalidade cultural (como gostar do mesmo estilo musical). Os outros seis critérios diziam respeito a (iii) praticam o mesmo esporte que você; $(i v)$ você costuma encontrar fora da escola; (v) você convidaria para ir a uma festa; (vi) com quem você gosta de fazer trabalhos escolares; (vii) torcem para o mesmo time de futebol que vocêt; e, por fim (viii) que você, de uma maneira geral, considera que são mais próximos de você. Os critérios utilizados são mostradas em detalhe no Apêndice B.

Os alunos recebiam uma lista com o nome de todos os matriculados naquela turma, semelhante a uma pauta escolar. A primeira etapa do teste consistia em solicitar que cada um riscasse da lista seu próprio nome. Isso identificaria quem era o respondente daquela lista. Então, as questões sociométricas eram verbalizadas aos alunos, por mim, uma a uma, aguardando aproximadamente um minuto para que pudessem marcar os colegas.

Mesmo que na data de coleta desses sociogramas, nem todos os alunos matriculados estivessem presentes, o que significa que a ficha não fora respondida por todos os participantes, (26/36 alunos estavam presentes e todos responderam a ficha), a análise dos sociogramas foi procedida com todos os alunos. Isso porque, mesmo que um determinado aluno não estivesse presente para elencar colegas, ele poderia ser elencado por alguém. Logo, seria um participante da rede social.

O processo de construção das redes sociais se seguiu, primeiramente transformando as fichas dos alunos (Fig. 27, superior) em matrizes de adjacências individuais, que se remetem ao grau de saída de cada aluno em relação aos colegas (Fig. 27, ao centro). Essa matriz de saída é, na verdade, uma pequena rede social de perspectiva ego $\rightarrow$ alteri (Fig. 27, abaixo), pela qual a pré-disposição do eu em relação aos próximos pode ser vista. Para

\footnotetext{
${ }^{4}$ não se pode ignorar a importância do futebol no Brasil enquanto elemento cultural, podendo funcionar como fator aglutinador ou como fator disruptivo dos grupos de pessoas.
} 
observação do grupo, as matrizes de adjacências individuais são somadas, gerando uma matriz de adjacências direcionada, logo, uma matriz não-simétrica, que indica a rede social direcionada (ego↔alteri) para um dos critérios sociométricos.

Figura 27 - Detalhamento dos processos do Teste sociométrico de um dos critérios. Acima, a folha dos respondentes. Ao centro, as matrizes de adjacências para cada indivíduo e a matriz de adjacências do grupo. Abaixo, as redes de saída de cada indivíduo, a partir de suas escolhas e a rede social do grupo, direcionada e não pesada, para um dos critérios sociométricos
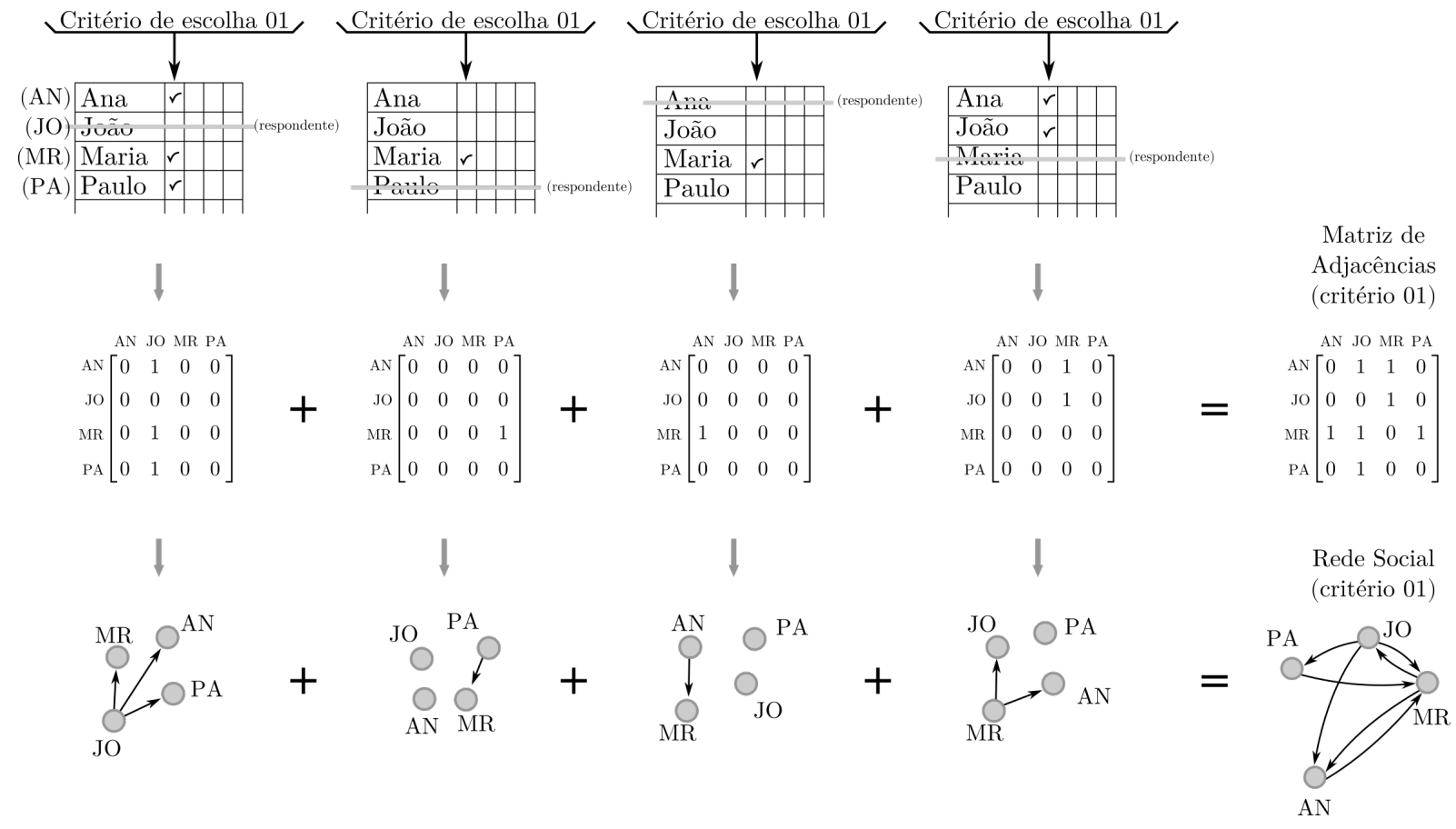

Fonte: elaboração nossa, adaptado de Rodrigues e Pietrocola (2020).

Os dados das fichas sociométricas foram transformados em um arquivo .CSV e foram importados para o ambiente R, e também tratados utilizando-se o pacote Igraph, visto que as estruturas sociométricas também são redes complexas. De cada critério sociométrico, produziu-se uma matriz de adjacências direcionadas e sem peso (Fig. 28, superior). Cada critério gerou uma rede direcionada, sem peso. Uma vez que cada relação é uma afiliação interpessoal, mesmo que não sendo mútua, os pesos referentes às arestas de saídas e de entradas foram somados e as matrizes de adjacências de cada critério foram concatenadas e transformadas numa matriz não direcionada e com arestas pesadas (Fig. 28, à direita). Isso permitiu a construção de uma rede social multi-critério, na qual as díades de alunos 
poderiam ter a força do lado social representada por um valor numérico (Fig. 28, inferior, à direita).

Figura 28 - Detalhamento do processo de concatenação das redes de todos os critérios sociométricos, originando uma rede não direcionada e com arestas tendo seu peso total considerado

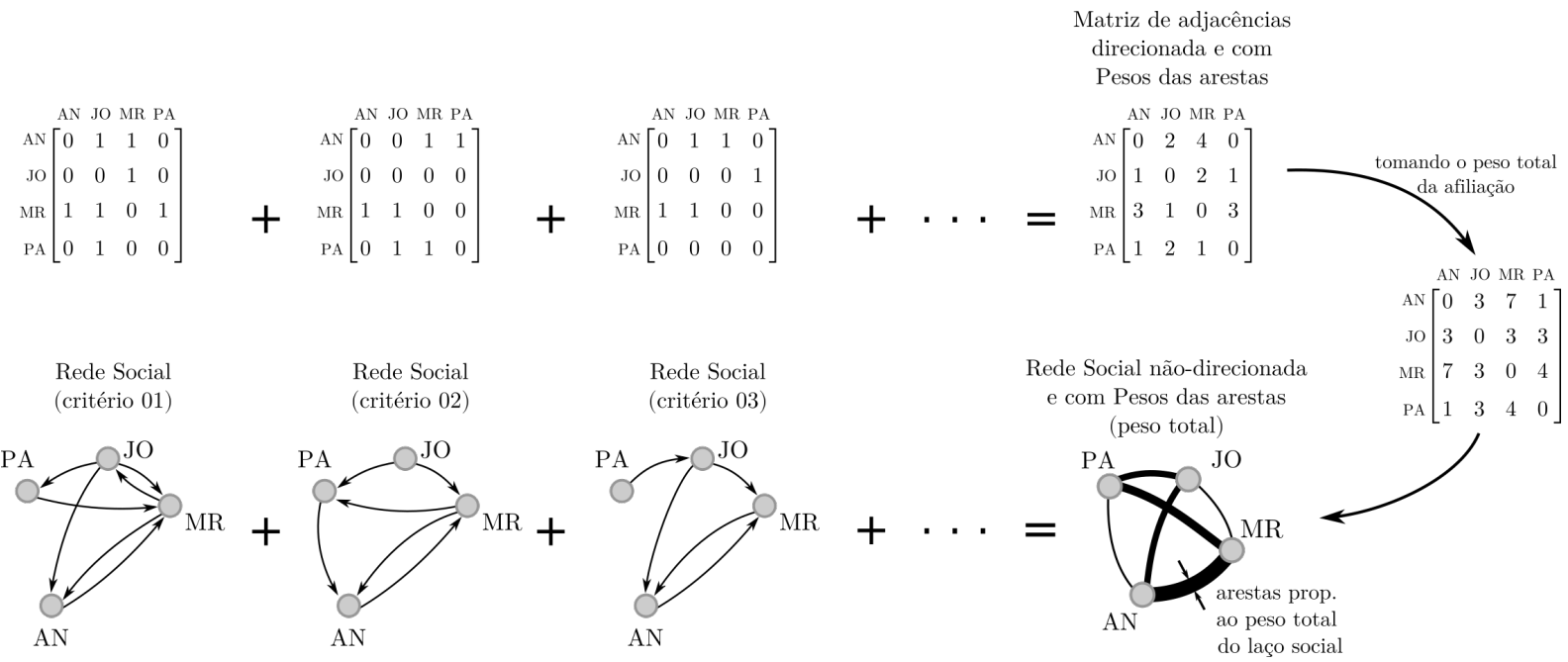

Fonte: elaboração nossa, adaptado de Rodrigues e Pietrocola (2020).

Da rede concatenada e pesada, um heatmap foi construído, indicando aglutinações de pares mais fortemente atados. Ainda, no sentido de se avaliar aleatoriedades ou não na estruturação da rede social, a distribuição dos graus totais, incluindo entrada e saída, de cada vértice, bem como a distribuição dos pesos das arestas, foram plotadas.

\section{Redução dimensional}

Tendo as redes dos dois domínios (semântico e social), procedemos a escolha de variáveis que pudessem ser analisadas como potenciais pontes entre essas dimensões. Elencamos todos os casos completos, ou seja, estudantes que formam um par na rede social e que tenham, ambos, respondido a atividade de evocação. Então, selecionamos como variáveis numéricas $(i)$ o valor do peso da aresta para cada possível díade de alunos; além disso contabilizamos em cada rede de palavras evocadas, o número de lexemas comuns aos dois estudantes da díade social, gerando como variável o número de palavras comuns para (ii) Calor; (iii) Física; (iv) Ciência; (v) Escola e (vi) Futuro, para prosseguirmos os passos 
de análise, apresentados na Tabela 3.

Tabela 3 - Sumário das variáveis numéricas para todos os pares de alunos (díades) e passos de processamento dos dados

\begin{tabular}{|c|c|c|c|c|c|}
\hline \multirow[t]{2}{*}{ Domínio } & \multicolumn{2}{|c|}{ Variáveis numéricas } & \multicolumn{3}{|c|}{ Processamento dos dados } \\
\hline & & & Passo 1 & Passo 2 & Passo 3 \\
\hline Social & \multicolumn{2}{|c|}{ ( $i$ ) Peso do laço social } & & & \\
\hline Semântico & $\begin{array}{l}\text { Número de } \\
\text { palavras } \\
\text { coincidentes } \\
\text { para: }\end{array}$ & $\begin{array}{l}\text { (ii) Calor } \\
\text { (iii) Física } \\
\text { (iv) Ciência } \\
\text { (v) Escola } \\
\text { (vi) Futuro }\end{array}$ & $\alpha_{\text {cronb }}$ & Teste Scree & PCA \\
\hline
\end{tabular}

Fonte: elaboração nossa, adaptado de Rodrigues e Pietrocola (2020).

O conjunto de variáveis numéricas foi obtido por uma automatização feita por script de $\mathrm{R}$ desenvolvido dedicado a esta tese (Apêndice E). As variáveis foram convertidas em um quadro de dados sobre o qual procedeu-se uma avaliação de consistência interna, pelo coeficiente $\alpha$ de Cronbach (CRONBACH, 1951), utilizando o pacote cocron (DIEDENHOFEN; MUSCH, 2016) do R.

Uma busca por reduzir a dimensionalidade dos dados numéricos foi feita, procedendose um Teste Scree (CATTELL, 1966), utilizando-se o pacote nFactors do R (RAICHE; MAGIS; RAICHE, 2010). O Teste Scree que serve para identificar em um conjunto multivariado, quantas dimensões, ou fatores, ou componentes, seriam substantivos para explicar a variação daqueles dados, permitindo assim uma redução de dimensões de análise àquelas dimensões que valem a pena serem analisadas e minimizando a perda de informação sobre os dados.

Definido o número de fatores a extrair, procedemos uma Análise de Componente Principal (PCA, do inglês Principal $\boldsymbol{C}$ omponent $\boldsymbol{A}$ nalysis) (WOLD; ESBENSEN; GELADI, 1987), com o pacote FactorMineR do R (LÊ et al., 2008). A PCA identifica padrões na matriz de dados, a partir de processos de rotação de eixos que minimizem a distância entre os pontos informativos e os eixos nos quais esses pontos se projetam. É uma forma de análise de estrutura de dados numéricos sedimentada para estudos exploratórios. Os componentes 
obtidos pela PCA foram avaliados a partir das projeções das variáveis numéricas, indicando dimensionalidade comum de informações advindas da rede social e dos consensos formados pelas díades de estudantes nas redes semânticas.

\subsection{Resultados}

\subsubsection{Representações sociais e descrição das redes de similaridade}

O instrumento de evocações de palavras, para a TALP, foi respondido por 22 estudantes, que originaram as cinco redes semânticas, uma para cada termo indutor. As redes de similaridades são apresentadas na Figura 29 à frente. A rede para Calor apresentou 48 palavras, formando 290 relações de co-ocorrência. Os termos Sol, fogo e praia foram os vértices de maior grau. Os pares Sol $\leftrightarrow$ praia, Sol $\leftrightarrow$ fogo e praia $\leftrightarrow$ fogo configuraram as arestas com maior valor de similaridade (Fig. 29, A).

Para Física, a rede mostrou 60 palavras formando 188 relações de similaridade. Cálculo, gravidade e fórmula tiveram os graus mais altos e os pares de maior similaridade foram calor $\leftrightarrow$ frio, cálculo $\leftrightarrow$ estudos e escola $\leftrightarrow$ professor (Fig. 29, B).

Para Ciência, a rede mostrou 52 palavras tendo corpo humano, animais e estudos com os graus mais altos. Além disso, formaram-se 151 pares de co-ocorrências, tendo as díades Física $\leftrightarrow$ Biologia, Física $\leftrightarrow$ Química e Química $\leftrightarrow$ Biologia com as maiores similaridades (Fig. 29, C).

As evocações para Escola totalizaram 60 palavras com 303 relações de co-ocorrência. Os termos professor, estudos e prisão configuraram os vértices com maiores graus e os pares professor $\leftrightarrow$ educ. física, professor $\leftrightarrow$ prova e professor $\leftrightarrow$ amigo foram os mais similares (Fig. 29, D).

A última rede, para Futuro teve 63 evocações, estruturada com 214 relações de co-ocorrência. Os termos trabalho, casa e faculdade foram os vértices de maiores graus e as arestas trabalho $\leftrightarrow$ faculdade, trabalho $\leftrightarrow$ dinheiro e carro $\leftrightarrow$ casa tiveram os maiores índices de similaridade (Fig. 29, E). 
Figura 29 - Redes de similaridades para os termos evocados: Calor (A); Física (B); Ciência (C); Escola (D) e Futuro (E). Diâmetros dos vértices proporcional ao grau na rede e espessura da aresta proporcional ao índice de similaridade de Russel

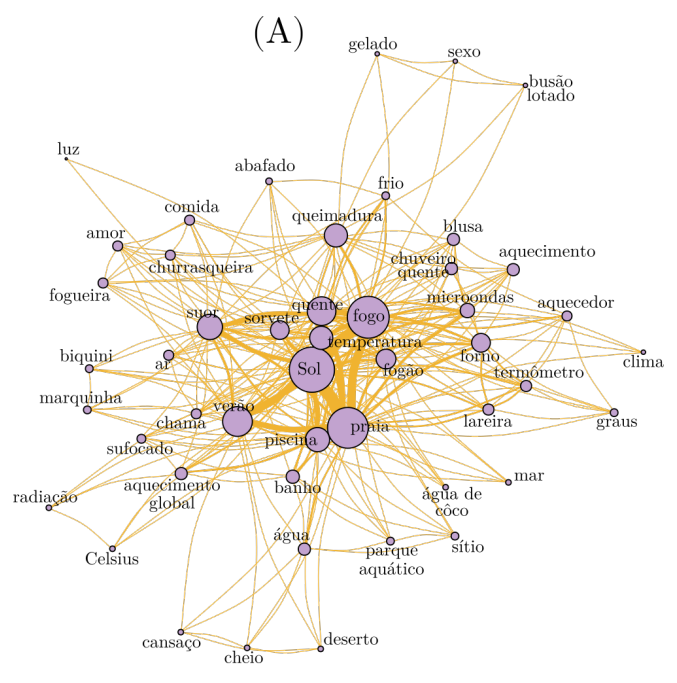

(C)

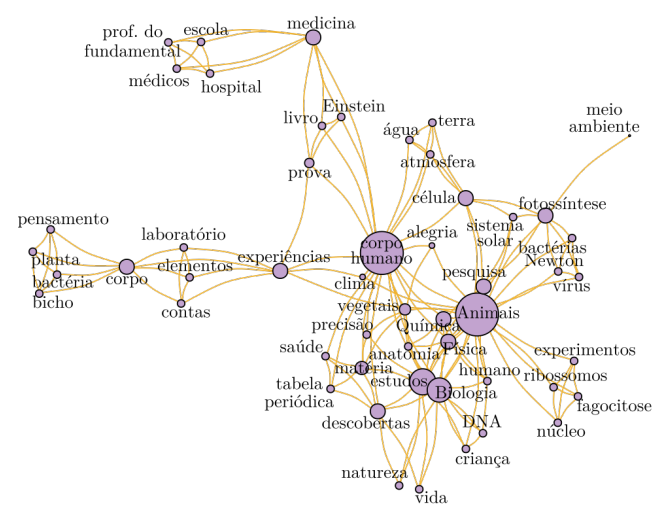

(B)

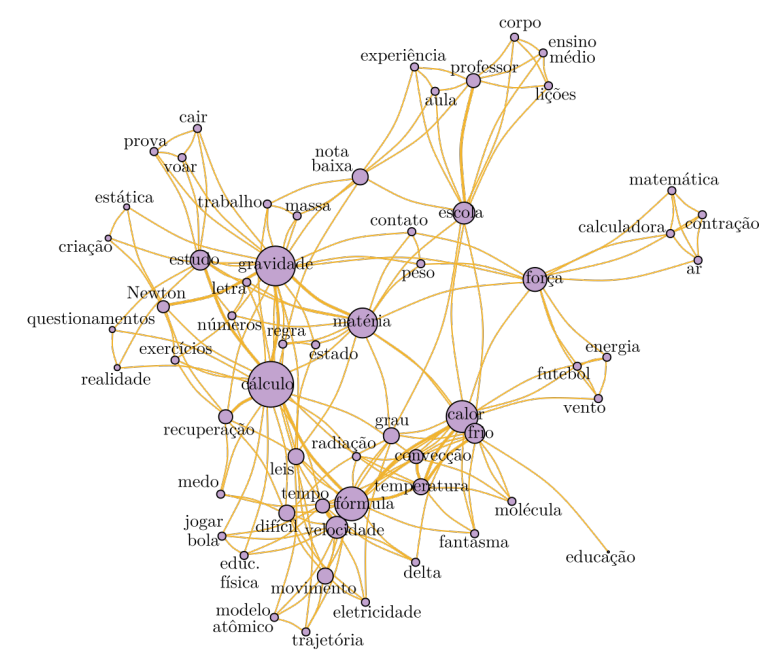

(D)

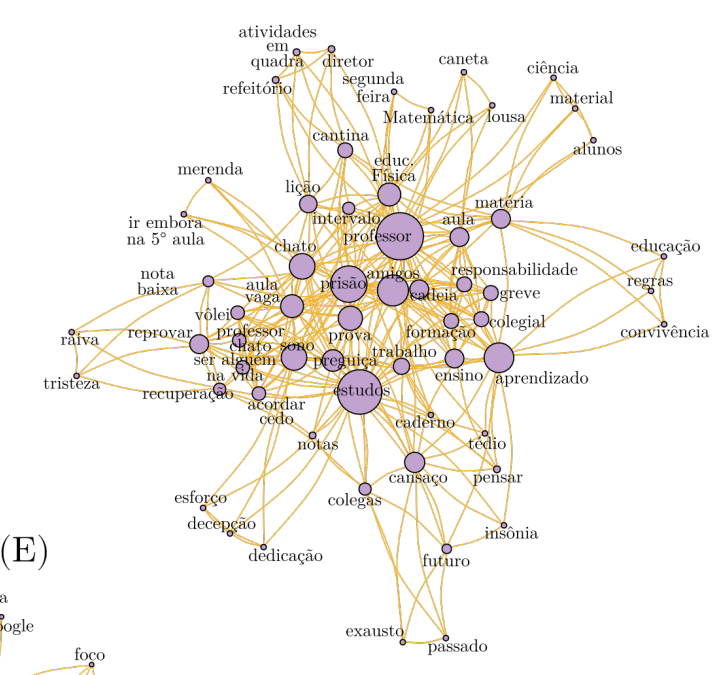

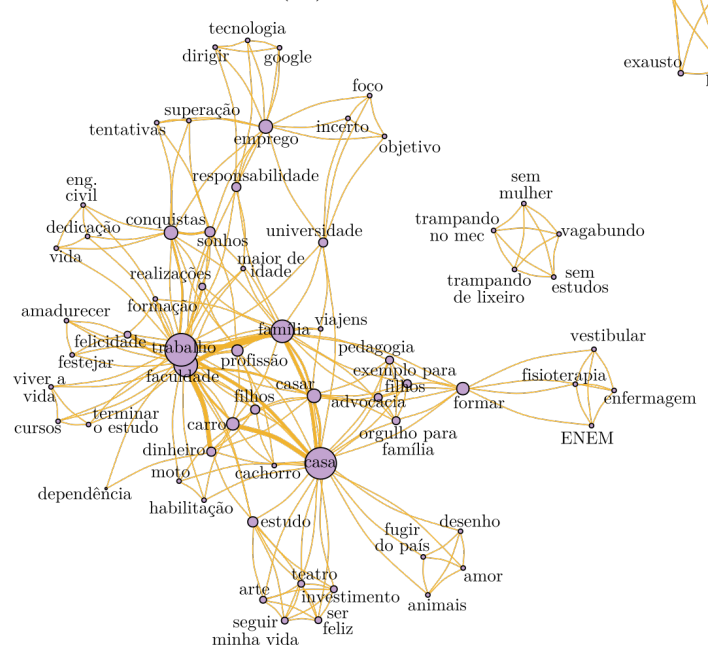

Fonte: elaboração nossa, adaptado de Rodrigues e Pietrocola (2020). 


\subsubsection{Laços interpessoais e descrição da rede social}

A rede social concatenada dos oito critérios sociométricos, com pesos das arestas, está mostrada na Figura 30.

Figura 30 - Redes social com arestas pesadas (acima). Heatmap da matriz de adjacências (inferior, à esquerda) e distribuição dos graus dos vértices e dos pesos das arestas (inferior, à direita)

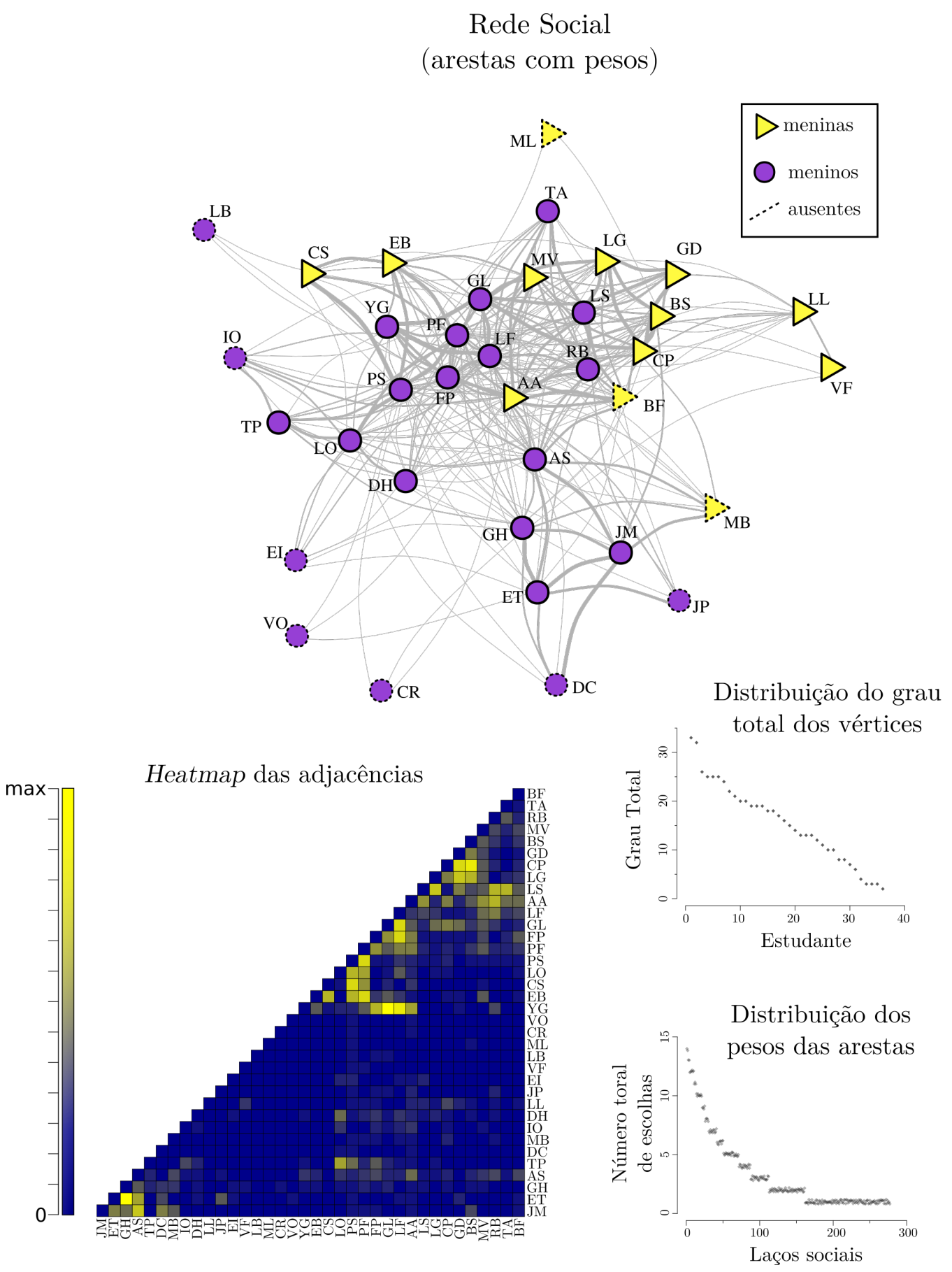

Fonte: elaboração nossa, adaptado de Rodrigues e Pietrocola (2020). 
Em relação aos indivíduos (perspectiva ego) os maiores graus $(d)$ são vistos nos alunos PS $(d=33)$, AA $(d=32)$ e PF $(d=26)$. Considerando uma perspectiva diádica (ego $\leftrightarrow$ alteri), a rede social mostrou 277 pares com laços sociais tendo peso variando de 1 a 14. O heatmap mostrado na Figura 30 (inf. esq.), que é uma representação gráfica da rede social, transformou a matriz $36 \times 36$ de adjacências em uma informação visual (Seç. 2.3, Cap. 2) e mostra os laços mais fortes em tons mais claros e os laços menos intensos e tons mais escuros.

A distribuição de arestas (Fig. 30, inf. à direita), apresenta os pares mais fortemente conectados tendo peso $w=14(G H \leftrightarrow E T$ e $Y G \leftrightarrow G L)$, seguidos por outros dois pares que se escolheram em 13 ocasiões $(B S \leftrightarrow C P$ and $Y G \leftrightarrow L F)$. Os laços sociais mais fortes são todos intra-sexo e, desses, apenas $B S \leftrightarrow C P$ são um par menina/menina. Os seis pares seguintes tiveram peso de aresta $w=12$, e dentre eles verifica-se o primeiro laço social inter-gênero.

\subsubsection{Redução dimensional via $P C A$}

O número total de casos completos (pares que tenham ambos respondido as evocações e os testes sociométricos) foi de 128 observações para as seis variáveis selecionadas. O índice de consistência interna dos dados foi $\alpha_{\text {cronb }}=0,607$. Embora não exista um ponto de corte para o valor da consistência interna, em levantamento de larga escala, recente publicado, Taber (2018) mostra que o valor encontrado é largamente aceito como satisfatório na pesquisa educacional.

O teste Scree sugere que a hipótese de dois componentes principais é suficiente para explicar a maior parte da variância dos dados. Isso é reforçado pela análise paralela, que indica a retenção de um único componente (Fig. 31, esq.). O primeiro componente principal recebe projeções (cargas) majoritariamente das variáveis: Peso do laço social $(o, 73)$; número de palavras coincidentes nas evocações para Calor $(0,75)$; e número de palavras coincidentes nas evocações acerca da Física $(0,73)$. Essas variáveis são seguidas pelo número de palavras coincidentes nas evocações sobre Ciência $(0,49)$, para Escola $(0,49)$ e para Futuro $(0,30)$, configurando a composição do primeiro componente principal, 
conforme mostrado na Figura 31, à direita, no eixo horizontal.

O segundo componente, indicado na Figura 31, à direita, no eixo vertical, teve carga 0,81 para os consensos emergentes nas evocações para Futuro, e 0,49 para o número de consenso ocorridos nas evocações sobre Escola. Todas as demais variáveis tiveram carga menor que 0,3 para o segundo componente principal.

Figura 31 - Teste Scree sugerindo a retenção de dois componentes principais (à esquerda) e mapa de variáveis projetando nos dois componentes (à direita)
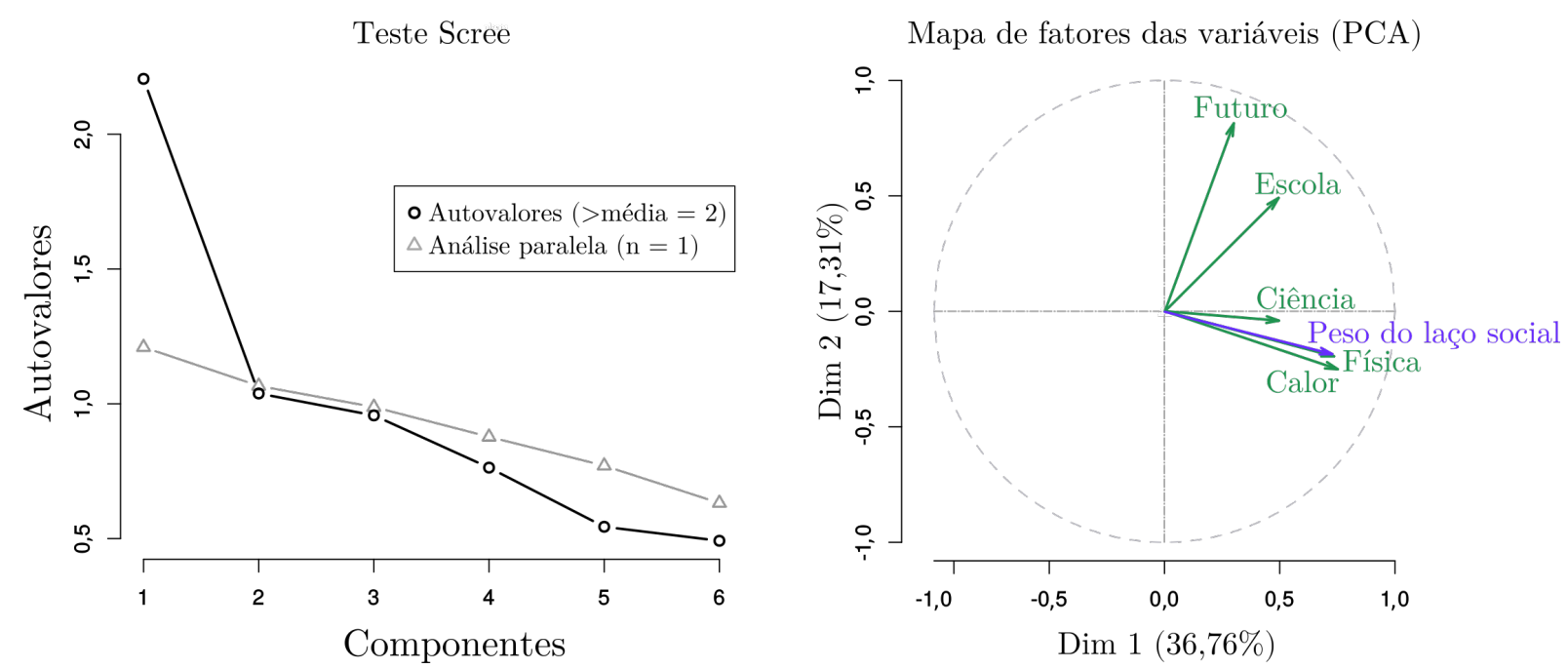

Fonte: elaboração nossa, adaptado de Rodrigues e Pietrocola (2020).

\subsubsection{Discussão dos resultados}

É possível ver, tanto nas redes semânticas quanto nas redes sociais, estruturas não-hierárquicas e, a pesar de serem detectáveis elementos centrais em ambos os casos, não se pode identificar claramente um controle central do sistema. Esses são traços de uma estruturação complexa, ocorrendo tanto no domínio social estrito dos alunos, quanto nas representações sociais emergentes.

As estruturas produzidas pelas co-ocorrências nas representações sociais, acomodam tanto elementos do senso comum, quanto termos do universo reificado, nos objetos representacionais escolares (Calor, Escola e Ciência). Conforme proposto por Chevallard (1991), o sistema escolar é a ponte existente entre a esfera do pensamento geral, por ele 
chamada de "noosfera", e a realidade dos estudantes no sistema didático. Esse sistema que é, de certa forma aberto (ou ao menos permeável) sobrepõe os dois universos, reificado e consensual, de Moscovici (1988). Por isso, são esperadas bordas difusas, combinando representações ligadas a diferentes fontes, nas evocações dos aluno.

As principais palavras e relações nas evocações para Calor (Fig. 29, A) são ideias do senso comum, enquanto elementos referentes a calor, tipicamente utilizados no discurso científico são esparsos. Termos do discurso científico parecem ser mais frequentes na rede para Física (Fig. 29, B), no entanto, comumente relacionados por uma suposta oposição, como calor $\leftrightarrow$ frio. Esse tipo de contraste é tomado no discurso científico reificado como sendo uma concepção alternativa. No entanto, circula no universo consensual dos alunos. São, portanto, um tipo de conhecimento que o grupo constrói para lidar com a sobreposição de demandas escolares e demandas da vida cotidiana.

Os padrões de co-ocorrência vistos nas redes, parecem ser consistentes com a teoria das representações sociais (MOSCOVICI, 1978) em sua abordagem estrutural (ABRIC, 1993): uma estrutura contendo núcleo e periferia. Um conjunto menor de elementos configura o núcleo central. Os elementos nucleares agregam a confusão da borda e, por isso, são elementos que têm maior poder de conexão com outros (MOLINER, 1994). Embora não exercendo controle central sobre o todo, os elementos nucleares da representação ajudam a organizar o campo representacional. Isso porque se formam historicamente, a partir da estabilidade reconhecida pelo grupo, emergindo de maneira consensual. São, nas redes da Figura 29, aqueles vértices de maior diâmetro.

O fato dos alunos, sistematicamente, evocarem Sol quando disparamos Calor como termo indutor, por exemplo, é a forma que eles têm para (nas palavras de Moscovici) transformar aquilo que é não-familiar em familiar. Ou seja, o não-familiar, em questão, são os referentes trazidos do saber sábio, do universo reificado, do contexto formal da Física. Considerando que os alunos estavam tendo aulas sobre transferência de calor na ocasião da pesquisa, as ideias trazidas pelo professor e presentes nos livros didáticos dos alunos penetram o grupo de estudantes aderindo, primeiro, às ideias que fazem sentido no cotidiano dos alunos. Em termos do processo de ancoragem, redes conceituais pré-existentes 
são descoladas para abarcar as ideias novas do saber-ensinado.

Representações sociais são construídas de modo a ajudar um grupo social a lidar com suas demandas sociais, com suas realidades sociais. Um profissional da ciência possivelmente tomaria calor como "uma quantidade de energia transferida" à primeira vista. Entretanto, os alunos, iniciando seus contatos com esse saber reificado, naturalmente não teriam tal ideia à primeira vista: uma vez que não se pode haver um objeto representacional para um grupo se os membros desse grupo não lidam com tal objeto em suas demandas cotidianas, não poderia haver um léxico reificado em relação a calor, circulando entre os alunos, se as demandas cotidianas não incluem tal léxico e se o grupo não o compartilha consensualmente.

O saber sábio, manifestado nos discursos profissionais e científicos, usa termos reificados em um mar de lexemas cujos sentidos se produzem a serviço das demandas do mundo reificado. Por isso, o desafio da educação científica não pode ser o de "converter" o senso comum dos alunos acerca de objetos da ciência em representações aceitas no âmbito reificado. Diferentes, o desafio é o de promover situações nas quais demandas reais escolares sejam parte da vida social dos estudantes. Assim, lidando com essas demandas, novas representações são produzidas pelo grupo. Essas representações se vulgarizam e se transformam em noções consensualmente compartilhadas que vem a circular entre os membros daquele coletivo.

A representação para Física (Fig. 29, B) trouxe uma questão do pensamento sobre essa disciplina como sendo focada em fórmulas e cálculos. Nossos achados corroboram resultados recentes publicados (STELLA et al., 2019), nos quais a análise de redes de co-ocorrência mostrou representações semelhantes. Além disso, elementos pragmáticos da Física podem ser vistos, embora não totalmente relacionados a calor, que era o tema trabalhado na ocasião. A presença do termo "calor", na rede, se associa fortemente a "frio". Novamente, isso indica que a chegada do assunto para aqueles alunos trazia elementos com os quais ainda não estavam familiarizados. Embora fossem alunos da segunda série do Ensino Médio, a rede para Física indica um consenso de sua relação com gravidade e com força, temas tipicamente trabalhados no ano anterior daqueles alunos. 
A representação de sentimentos negativos em relação à Físicas, como notas baixas, medo e recuperação, sugere que a disciplina é vista pelos alunos como um obstáculo epistêmico a priori. Estando no início do segundo terço de seu ensino médio, a possibilidades de que a essa disciplina pudesse se tornar agradável e de aprendizado sem percalços não é vista como consenso.

Vê-se que da rede para Ciência (Fig. 29, C) emerge um núcleo de elementos típicos da Biologia (como "animal" e "corpo humano"). Isso, mesmo sendo uma pesquisa conduzida no contexto do ensino e aprendizagem da Física. Essa representação pode ser influenciada por uma visão estereotipada de como é a ciência. Essa visão é consistente com representações sociais do cientista, levantadas em duas universidades públicas brasileiras (BROCKINGTON et al., 2019), que apontam uma distância entre as imagens do cientista e do professor de ciências, relegando ao primeiro uma visão caricata.

A rede para Escola nos leva de volta ao triângulo didático chevallariano. A assimetria marcante no triângulo, que tem a figura do professor ocupando, sozinha, um vértice do sistema, indica a inegável importância do docente no processo. Mesmo para professores nos ambientes de ensino mais democráticos, supõe-se uma autoridade de ordem epistêmica e social em sala de aula. Essa importância do professor é uma imagem compartilhada socialmente, como visto na (Fig. 29, D), na qual o professor é elemento central e forma as principais relações de conexidade.

Diferente das redes anteriores, a rede para Escola não indica uma tensão entre discursos profissionais da ciência e aqueles do senso comum. Mas, por outro lado, indica uma imagem construída ao longo dos anos, pelos alunos, em suas vidas escolares. A escola é uma demanda cotidiana da vida social dos alunos. Mesmo que ambientes de ensino contemporâneos tendam a focar em apoio aos estudantes, a rede mostra uma imagem professor-cêntrica. No entanto, isso não necessariamente está em oposição às visões menos verticalizadas do professor. Isso pode ser notado na forte associação entre "professor" e "amigo" na rede, algo que confirma uma centralidade do docente, numa visão positiva.

Mas, contraditoriamente, a rede para Escola também carrega visões negativas, como "chato" e "prisão". Podemos pensar sobre esse aspecto considerando que, mesmo 
que o professor tivesse uma postura sistematicamente amigável, a escola, em seu arranjo tradicional, ainda representa um elemento estrutural que se impõe sobre os alunos. Os elementos dessa imagem negativa nos levam a uma reflexão: alguém só pode estar em uma prisão quando é colocado em um ambiente aprisionante. Representar a escola como um lugar que aprisiona sugere um desafio: o de fomentar formas de empoderar os estudantes, ativando suas agências para que vivam a escola pública não como um lugar dentro do qual eles são colocados, mas como um lugar que é deles, feito por eles. Uma pessoa não estará jamais aprisionada a um lugar do qual se sente pertencente. Se a escola é um lugar do qual os estudantes fazem parte, ao invés de um lugar no qual os estudantes estão, as demandas da vida social dos alunos mudam, passando a necessitar de representações do "a que pertenço" e não representações do "que me aprisiona", como as vistas.

Apesar da presença de elementos negativos em relação à Escola, o grupo parece manter um valor nos estudos, considerando-o como sendo porta de saída de adversidades socioeconômicas. Os elementos nucleares da rede para Futuro (Fig. 29, E) se ancoram indícios de desejo por justiça social e dignidade: seja nos elementos de maior grau, que remetem a prospecções de ter um emprego, construir uma casa ou se casar, seja nas relações mais fortes, que ligam faculdade a trabalho e trabalho a dinheiro, há um indício de que os estudantes compartilham a visão de que dar sequência à formação acadêmica colabora com suas visões de futuro desejado. Reforçando a visão de valor atribuído, pode-se ver um sub-grafo desconectado nessa rede, contendo uma leitura negativa de futuro, associada à não conclusão dos estudos. Isso confirma uma representação na qual há uma forte relação entre escolarização e oportunidades futuras de trabalho.

Para além de uma análise do conteúdo representacional, nós exploramos a complexidade por redes trazidas de dois domínios (semântico e social), particularmente interessados nas díades de alunos e se essas díades estariam ou não relacionadas aos consensos emergentes no âmbito representacional, mostrados acima. Neste caso, a redução dimensional sustenta a noção de que os pesos dos laços sociais da sala de aula estão, de fato, relacionados à formação de consensos. Mas não sobre qualquer tema.

O resultado da PCA mostrou uma dimensão prioritária ( $1^{\circ}$ componente principal), 
na qual o peso dos laços sociais se projeta, majoritariamente, junto aos consensos formados para temas intra-escolares. As projeções mais fortes da variável social com a variável consensual de Calor, Física e Ciência, formando um componente convergem com a proposta de Saxe et al. (2009) que propunham a importância do peso das díades como elemento social da viagem de ideias por um grupo de alunos.

O mapa de variáveis da PCA (Fig. 31), mostra que, quanto mais distantes da realidade escolar direta dos alunos e mais extra-escolares os temas vão se tornando, mais seus consensos se tornam independentes da força dos laços sociais. Considerando que o sistema complexo da sala de aula é permeável, as realidades dos alunos não são apenas as realidades escolares. A rede social e as representações que dela emergem estarão sempre em interação com uma esfera mais ampla, como uma noosfera mais larga que o espaço delimitado pelos muros da unidade escolar. Prospecções de futuro, por exemplo, são emergências de uma complexa sobreposição de valores, fatos e crenças que são menos guiados pela estruturação interpessoal da sala de aula.

\subsubsection{Conclusão do estudo de caso}

Neste trabalho empírico, utilizamos a abordagem de redes para investigarmos as estruturações sociais e semânticas em uma sala de aula e, com isso, explorarmos a complexidade das relações entre esses dois domínios. Utilizamos a força dos laços interpessoais e os consenso em cada objeto representacional para criar uma ponte entre o social estrito e o representacional dos alunos.

É natural que as representações compartilhadas por membros de um grupo social não podem ser pensadas como disjuntas do grupo em sim. Nossos resultados neste estudo indicam essa impossibilidade de separação. A interdependência entre as amarras interpessoais e o compartilhamento de ideias sobre objetos próximos da realidade intra-escolar dos alunos é maior do que sobre objetos que sobrepõem mais claramente o mundo exterior à vida diária na escola.

A abordagem de redes para os dois domínios estudados se mostrou frutífera como forma de se pensar as estruturações em suas complexidades, permitindo a construção 
de panoramas de interpretação de ambos. Mas também se mostrou útil como método para representação explícita do aspecto relacional das ideias e das pessoas, presentes em sala de aula. É claro que, como cada aluno é uma sobreposição de uma multitude de diferentes grupos sociais, cada um deles compartilhando diferentes valores e produzindo suas próprias identidades, as produções representacionais de temas não-escolares sempre serão compartilhadas entre os alunos e os participantes de uma comunidade mais ampla que a escolar. 


\section{Considerações finais}

Meu coração tropical partirá esse gelo e irá.

Aldir Blanc

$\mathrm{P}$

UDEMOs discutir, ao longo deste trabalho, os aspectos relacionais da sala de aula, característica que nos faz encará-la em suas complexidades inerentes, manifestadas em múltiplos níveis de relações. Também pudemos utilizar as redes como forma de pensamento sobre a complexidade e como método, no qual informações fornecidas pelos alunos permitiram a construção de grafos, que se tornaram representações explícitas das estruturas complexas, emergentes daquele grupo de estudantes.

Iniciamos esta tese como o objetivo geral de explorar aspectos da complexidade a partir do uso das redes complexas, emergentes tanto do âmbito interpessoal quanto do âmbito representacional, visando elucidar seus processos mútuos de estruturação. (Seç. 1.5). Nesse sentido, atinentes aos dois primeiros objetivos específicos, mostramos como as redes são, ao mesmo tempo, formas de produção de inscrições sobre o mundo e um conjunto de pontes entre o mundo e as inscrições, pelas quais as inscrições circulam e nas quais um sentido pode ser produzido (Item 2.2.3).

Essa ampliação do mundo pode ser vista no trabalho cientométrico do Capitulo 3, no qual as redes que sumarizam o panorama das publicações são as mesmas que nos permitem ampliar a visão sobre o cenário de produção acadêmica. Também ocorre na pesquisa empírica, relatada no Capítulo 5, na qual o sentido sobre a estruturação dos alunos e o compartilhamento que eles têm das ideias, é feito pelas redes. Tanto pelas redes como grafos, que servem de inscrições da complexidade daquele cenário escolar, quanto pelas redes de circulação.

Nessas últimas, nosso trabalho de pesquisa implica em constantes idas e vindas entre as inscrições e a realidade escolar, produzindo sobre ela cartografias. Assim como 
nos mapas, que ampliam o mundo por inscrevê-lo numa carta, as redes nos fazem olhar a sala de aula de maneira ampliada. Declarações sociométricas nos mostraram pares cujas afiliações não necessariamente são aquelas da proximidade física da sala de aula, mas de comunalidades culturais, como futebol e música, ou de convivência extra-escolar. O fato de que isso não poderia ser observado diretamente coloca nosso método como alternativa viável para o entendimento da sala de aula, para além das formas mais estabelecidas da pesquisa, de inclinação semiótica.

Os resultados reportados no Capítulo 5, além de atenderem aos quatro últimos objetivos específicos descritos inicialmente, também nos dão um apontamento. Uma vez que os consensos sobre temas intra-escolares são mais dependentes da força da afiliação interpessoal, uma necessidade de fomento de construção de laços aluno/aluno parece ser clara. E não apenas como forma de promoção de uma sala de aula mais colaborativa, o que, por si só, já se justificaria, mas porque isso é mola da produção do saber consensual dos estudantes. Isso é consistente com o sistema didático chevallariano, pois a aresta alunos $\leftrightarrow$ conhecimento é a sobreposição das vidas cotidianas dos estudantes e das formas institucionalizadas do saber que a escola opera.

\section{Desdobramentos de ordem metodológica}

Diante dos desafios de se proceder uma análise em diferentes domínios de manifestação da complexidade, o processo trouxe diferentes ganhos. Um deles foi o desenvolvimento de novos protocolos que habilitassem nossa capacidade de operação multi-nível da complexidade. Mesmo sendo as redes arranjos complexos em cada uma de suas dimensões, pudemos inferir mecanismos de ponte entre as complexidades adjacentes numa seleção de variáveis e por uma redução dimensional, que foram úteis para produção de uma visão inter-domínio.

Mantendo um compromisso com a ruptura das barreiras dos direitos autorais e dos custos de compras de softwares, todos os protocolos de análise foram desenvolvidos e utilizando-se plataformas computacionais gratuitas, de código aberto e amplamente 
disponíveis. Todos os scripts de análise estão disponibilizados. Tanto para a análise cientométrica procedida (Apêndice D) quanto para as redes sociais e semânticas do estudo de caso (Apêndice E). Esse compartilhamento visa tanto a abertura para que, no debate acadêmico, o processo possa se submeter ao escrutínio dos pares e, então, aprimorado, quanto para que possa ser utilizado por outras pesquisas que se valham das mesmas bases que esta.

Uma característica do nosso uso das redes enquanto matriz técnica, é que nossas análises neste trabalho se voltaram às estruturas emergentes, sincronicamente. Há uma vantagem em se proceder dessa foram: de maneira sincrônica, as redes podem ser remetidas a um momento específico e posicionadas dentro de um contexto particular, bem definido. Se tornam cartografias que congelam o espaço e o tempo. Entretanto, dentro dessa proeminente ciência das redes e de seu uso na pesquisa em educação científica, a vanguarda parece apontar para duas direções que, certamente, impactarão nossas próximas investidas de pesquisa na perspectiva defendida na presente tese.

Uma delas é acerca dos aspectos diacrônicos das redes da sala de aula. Analisar a dinâmica das redes é poder explorar, para além da complexidade inerente a uma cartografia espaçotemporal fixa, uma evolução temporal das diferentes estruturações que emergem da sala de aula. Outro aspecto importante para estudos futuros é o avanço nas análises das chamadas "redes multi-camadas" (KIVELÄ et al., 2014; STELLA; KENETT, 2019), que também podem ser utilizadas como ferramenta para sobreposição de complexidades de diferentes domínios. Essas possibilidades colocam este estudo de caso como o passo inicial de uma trajetória ainda a ser percorrida, para a investigação da sala de aula a partir de suas inúmeras formas e naturezas de redes emergentes.

\section{Ciência das redes também para outras complexidades escolares}

Nosso desenvolvimento de uma abordagem de redes, para lidar com complexidades em múltiplos níveis, pode ser levado a outros cenários. A investigação das estruturações interpessoais e representacionais não se encerra neste trabalho. Mas nos parece claro 
que sua ampliação vai além da replicação, incluindo sua transposição de cenários e de temas. Se acatarmos a noção central de que há uma complexidade inerente àquilo que chamamos por realidade, reconheceremos que essa complexidade impõe desafios ao processo de escolarização. Particularmente relação à educação científica, que precisa ser ancorada às novas formas de vida, imersas de novas formas de relações sociais e de relações com a ciência e com a tecnologia.

Por isso, uma educação científica contemporânea precisa situar os estudantes na complexidade e no dinamismo do mundo. Para isso, precisa ser o âmbito no qual novas ferramentas intelectuais possam ser produzidas e compartilhadas pelos alunos. de modo a serem não apenas constituintes do mundo mas, ao mesmo tempo, agentes transformadores desse mesmo mundo. E isso significa que as redes e a complexidade são mais do que ferramentas do pensar e ferramentas do fazer da pesquisa, podendo sê-los também do ensino. Temas complexos do ensino são, naturalmente, aderentes à perspectiva das redes.

Problemas categorizados como sendo menos que caóticos e mais que conhecidos (KURTZ; SNOWDEN, 2003) representam situações nas quais as redes não determinísticas são formas de produção de saber. Diante de tamanho crescimento na complexidade dos cenários reais, as novas fronteiras do conhecimento não podem ser claramente definidas e as novas demandas da humanidade são, em si, problemas complexos dos quais fazemos sentido somente em retrospecto. As redes nos foram ferramentas para acessar traços da complexidade da sala de aula. Logo, é factível considerá-las como potenciais ferramentas para lidar com as novas questões da humanidade, que sejam também complexas.

\section{Olhando adiante}

A produção de uma tese é o momento que encerra o último ciclo de formação de um pesquisador. Mas isso não significa que um doutoramento seja um ciclo que se encerra em si. Se um olhar do presente para trás for lançado, pode-se avaliar que os resultados, os acoplamentos teóricos e as técnicas de análise propostas no presente texto concluem um ciclo e fecham um período de profunda mudança em múltiplas instâncias de vida, para 
este autor.

Entretanto, se um olhando do presente para frente for lançado, vê-se que o encerramento desse período de mudanças marca o início de uma carreira, de uma trajetória de pesquisa. Por isso, deve também iniciar novos períodos nos quais algumas das ideias aqui presentes se solidificarão. Mas que nunca deixem de ser períodos de transformação. E isso aponta a necessidade de que as "verdades" aqui defendidas estejam sempre em questão e que ganhem sempre novos contornos.

Dessa forma, o desejo é de que o mergulho nas complexidades dos processos de escolarização possa ir cada vez mais fundo. Que novas formas de interpretação e novas prospecções sobre o desenvolvimento humano dos alunos possam ser feitas. E que, assim, possamos avançar no entendimento sobre aquele mundo, pequeno como a distâncias entre as paredes da escola mas, ao mesmo tempo, gigante como um universo em constante transformação. 


\section{Referências}

ABRIC, J. C. Central system, peripheral system: their functions and roles in the dynamics of social representations. Papers on social representations, v. 2, n. 2, 1993. Citado 4 vezes nas páginas 143, 145, 164 e 183.

ALlEN, T. René Magritte, the essential. New York, NY: The Wonderland Press, 1999. Citado na página 50.

ALMEIDA, A. M. O.; CUNHA, G. G. Representações sociais do desenvolvimento humano. Psicologia: reflexão e crítica, v. 16, n. 1, p. 147-155, 2003. Citado na página 144.

ALVES, D. J. O teste sociométrico. [S.l.]: Fundação Getúlio Vargas, Serviço de Publicações, 1964. v. 1. Citado na página 150.

ALVES, L. G. et al. The nested structural organization of the worldwide trade multi-layer network. Scientific Reports, v. 9, n. 1, p. 2866, 2019. Citado na página 108.

ALVES-MAZZOTTI, A. J. Representações sociais: aspectos teóricos e aplicações à educação. Revista Múltiplas Leituras, v. 1, n. 1, p. 18-43, 2008. Citado na página 144.

ANGELI, C.; VALAINDES, N. Examining the effects os electronic mentoring prompts on learners' scientific reasoning skills in a text-based online conference for a science education course. Science Education International, v. 19, n. 4, p. 357-369, 2008. Citado na página 127.

ARAÚJO, A. M. O salto qualitativo em Theodosius Dobzhanky: unindo as tradições naturalista e experimentalista. História, ciências, saúde: Manguinhos, v. 8, n. 3, p. 713-726, 2001. Citado 2 vezes nas páginas 72 e 73.

ARAÚJO, D. Bom Jesus do Norte, a cidade que é do norte, mas que fica ao sul do ES. 2019. Disponível em: <https://glo.bo/32h6Eb4>. Citado na página 134.

BAKER, N. A network of science: 150 years of Nature papers. Nature Publishing Group, 2019. Disponível em: < https://www.nature.com/articles/d41586-019-03325-6>. Citado na página 61.

BARABÁSI, A.-L. Linked: how everything is connected to everything else and what it means for business. New York, NY: Plume Books, 2003. Citado na página 162.

BARABÁSI, A.-L. Network science. [S.l.]: Cambridge University Press, 2016. Citado 4 vezes nas páginas 111, 113, 116 e 120.

BARABÁSI, A.-L. et al. Evolution of the social network of scientific collaborations.

Physica A: Statistical mechanics and its applications, v. 311, n. 3-4, p. 590-614, 2002.

Citado na página 109.

BERTALAnFFY, L. V. Teoria geral dos sistemas. 3. ed. [S.1.]: Petrópolis: Vozes, 2010. Citado 4 vezes nas páginas 68, 70, 121 e 154.

BORGATTI, S. P.; EVERETT, M. G. A graph-theoretic perspective on centrality. Social 
Networks, v. 28, n. 4, p. 466-484, 2006. Citado na página 119.

BORGATTI, S. P. et al. Network analysis in the social sciences. Science, American Association for the Advancement of Science, v. 323, n. 5916, p. 892-895, 2009. Citado 3 vezes nas páginas 147, 150 e 165.

BREWE, E.; BRUUN, J.; BEARDEN, I. G. Using module analysis for multiple choice responses: A new method applied to force concept inventory data. Physical Review Physics Education Research, v. 12, n. 2, p. 020131, 2016. Citado na página 127.

BROCKINGTON, G.; PIETROCOLA, M. Serão as regras da transposição didática aplicáveis aos conceitos de física moderna? Investigações em Ensino de Ciências, v. 10, n. 3, p. 387-404, 2005. Citado 2 vezes nas páginas 44 e 164.

BROCKINGTON, G. et al. Pre-service teachers' social representation on scientist and science teacher: Between two distant worlds. In: ESERA 2019 - European Science Education Research Association. Bologna, Italia: [s.n.], 2019. Citado na página 185.

BROWN, N. J. S. et al. Competence reconceived: The shared enterprise of knowledge analysis and interaction analysis. In: Knowledge and Interaction. 1. ed. [S.l.]: Routledge, 2015. cap. 1, p. 11-29. Citado 2 vezes nas páginas 50 e 51.

BRUUN, J. Networks as integrated in research methodologies in per. 2016 PERC Proceedings, p. 11-17, 2016. Citado na página 56.

BRUUN, J.; BREWE, E. Talking and learning physics: Predicting future grades from network measures and force concept inventory pretest scores. Physical Review Special Education Research, v. 9, n. 2, p. 020109, 2013. Citado 3 vezes nas páginas 127, 130 e 131.

CAPRA, F. The web of life: a new scientific understanding of living systems. 1. ed. New York, NY: Anchor Books, 1996. Citado na página 90.

CARBOnE, R. A.; STÉFAnO, M. S. M. D. Injustiça na escola: representações sociais de alunos do ensino fundamental e médio. Educação e Pesquisa, v. 30, n. 2, p. 251-270, 2004. Citado na página 144.

CAREY, S. Knowledge acquisition: Enrichment or conceptual change. In: Cambridge, MA: MIT Press, 1999. p. 459-487. Citado na página 92.

CATTELL, R. B. The scree test for the number of factors. Multivariate Behavioral Research, v. 1, n. 2, p. 245-276, 1966. Citado na página 177.

CHARDIN, P. T. The phenomenon of man. New York, NY: Harper Perennial Modern Classic, 2008. Citado na página 45.

CHEN, P.-T.; HSIEH, H.-P. Personalized mobile advertising: Its key attributes, trends, and social impact. Technological Forecasting and Social Change, v. 79, n. 3, p. 543-557, 2012. Citado na página 53.

CHEVALLARD, Y. La transposición didáctica: del saber sabio al saber enseñado. Buenos Aires, Ag: Aique, 1991. Citado 8 vezes nas páginas 42, 43, 44, 46, 138, 158, 163 e 182.

CHILDRESS, S.; BENSON, S. Personalized learning for every student every day. Phi Delta Kappan, v. 95, n. 8, p. 33-38, 2014. Citado na página 53. 
CHRISTAKIS, N. A.; FOWLER, J. H. The spread of obesity in a large social network over 32 years. New England Journal Of Medicine, v. 357, n. 4, p. 370-379, 2007. Citado 2 vezes nas páginas 108 e 162.

CICUTO, C. A. T.; CORREIA, P. R. M. Análise de vizinhança: uma nova abordagem para avaliar a rede proposicional de mapas conceituais. Revista Brasileira de Ensino de Física, v. 34, n. 1, p. 1-10, 2012. Citado na página 163.

CILLIERS, P. Boundaries, hierarchies and networks in complex systems. International Journal of Innovation Management, v. 5, n. 02, p. 135-147, 2001. Citado 2 vezes nas páginas 77 e 120.

COLLINS, R. On the microfoundations of macrosociology. American Journal Of Sociology, v. 86, n. 5, p. 984-1014, 1981. Citado na página 88.

CRONBACH, L. J. Coefficient alpha and the internal structure of tests. Psychometrika, v. 16, n. 3, p. 297-334, 1951. Citado na página 177.

CSARDI, G.; NEPUSZ, T. The igraph software package for complex network research. InterJournal, Complex Systems, p. 1695, 2006. Citado na página 172.

DEAMER, D. On the origin of systems: Systems biology, synthetic biology and the origin of life. EMBO reports, v. 10, n. 1, p. 1-4, 2009. Citado na página 71.

DEYNE, S. D.; NAVARRO, D. J.; STORMS, G. Better explanations of lexical and semantic cognition using networks derived from continued rather than single-word associations. Behavior research methods, v. 45, n. 2, p. 480-498, 2013. Citado na página 170 .

DIEDENHOFEN, B.; MUSCH, J. cocron: A web interface and R package for the statistical comparison of cronbach's alpha coefficients. International Journal of Internet Science, v. 11, n. 1, p. 51-60, 2016. Citado na página 177.

DISESSA, A. The Patterns Project. 2013. < https://gse.berkeley.edu/patterns-project>. Acesso em: 09-02-2020. Citado na página 26.

DISESSA, A. A. Toward an epistemology of physics. Cognition and Instruction, v. 10, n. 2-3, p. 105-225, 1993. Citado 2 vezes nas páginas 27 e 94.

DISESSA, A. A. Why "conceptual ecology" is a good idea. In: __ Reconsidering conceptual change: Issues in theory and practice. [S.l.]: Springer, 2002. p. 28-60. Citado 2 vezes nas páginas 94 e 95.

DISESSA, A. A.; SHERIN, B. L. What changes in conceptual change? International Journal Of Science Education, v. 20, n. 10, p. 1155-1191, 1998. Citado 2 vezes nas páginas 27 e 94.

DOBZHANSKY, T. Genetics and the Origin of Species. 3. ed. [S.l.]: Columbia University Press, 1951. Citado na página 73.

DURKHEIM, E. The rules of sociological method. Chicago, IL: University of Chicago Press, 1896. Citado na página 39.

DUVEEN, G. Introdução: o poder das ideias. In: Representações sociais: 
investigações em Psicologia Social. 11. ed. [S.1.]: Vozes Rio de Janeiro, 2015. p. 7-13. Citado na página 134.

EAMES, C.; STEWART, K. Personal and relationship dimensions of higher education science and engineering learning communities. Research in Science $\&$ Technological Education, v. 26, n. 3, p. 311-321, 2008. Citado na página 127.

EULER, L. Solutio problematis ad geometriam situs pertinentis. Commentarii Academiae Scientiarum Petropolitanae, p. 128-140, 1741. Citado 2 vezes nas páginas 110 e 111.

FARMER, T. W.; RODKIN, P. C. Antisocial and prosocial correlates of classroom social positions: The social network centrality perspective. Social Development, v. 5, n. 2, p. 174-189, 1996. Citado na página 162.

FEHR, A. V. D.; SØLBERG, J.; BRUUN, J. Validation of networks derived from snowball sampling of municipal science education actors. International Journal of Research $\mathbb{E}$ Method in Education, v. 41, n. 1, p. 38-52, 2018. Citado na página 127.

FERNANDES, S. J.; RODRIGUES, E. V.; CAMILETTI, G. Traços motivacionais como orientação para a prática docente. In: Anais do X ENPEC - Encontro de Pesquisa em Ensino de Ciências. Águas de Lindóia, SP: [s.n.], 2015. Disponível em: <http://www.abrapecnet.org.br/enpec/x-enpec/anais2015/resumos/R0419-1.PDF>. Citado na página 30.

FERRACIOLI, L. O 'v'epistemológico como instrumento metodológico para o processo de investigação. Revista Didática Sistêmica, v. 1, n. 4, p. 106-125, 2005. Citado na página 26.

FERRACIOLI, L. Mapas conceituais como instrumento de eliciação de conhecimento. Revista Didática Sistêmica, v. 5, n. 1, p. 65-75, 2007. Citado na página 26.

FLANDERS, N. A. Interaction analysis and inservice training. The Journal of Experimental Education, v. 37, n. 1, p. 126-133, 1968. Citado na página 39.

FORSMAN, J.; MOLL, R.; LINDER, C. Extending the theoretical framing for physics education research: An illustrative application of complexity science. Physical Review Special Education Research, v. 10, n. 2, p. 020122, 2014. Citado na página 127.

FREEMAN, L. The development of social network analysis. [S.l.]: Empirical Press, 2004. v. 1. Citado 4 vezes nas páginas 146, 147, 150 e 165.

GALLAGHER, R.; APPENZELLER, T. Beyond reductionism. Science, v. 284, n. 5411, p. 79-80, 1999. Citado na página 74.

GANNA, A. et al. Large-scale GWAS reveals insights into the genetic architecture of same-sex sexual behavior. Science, v. 365, n. 6456, p. eaat7693, 2019. Citado na página 74 .

GAO, J.; BARZEL, B.; BARABÁSI, A.-L. Universal resilience patterns in complex networks. Nature, v. 530, n. 7590, p. 307, 2016. Citado 2 vezes nas páginas 108 e 119.

GASCÓN, J. Evolución de la didáctica de las matemáticas como disciplina científica. Recherches en didactique des mathématiques, v. 18, p. 7-34, 1998. Citado na página 42. 
GATES, A. J. et al. Nature's reach: narrow work has broad impact. [S.l.]: Nature Publishing Group, 2019. Citado 3 vezes nas páginas 60, 61 e 109.

GIACOMO, J. P. D. Intergroup alliances and rejections within a protest movement (analysis of the social representations). European Journal of Social Psychology, v. 10, n. 4, p. 329-344, 1980. Citado 2 vezes nas páginas 145 e 170.

GIDDENS, A. The constitution of society: Outline of the theory of structuration. [S.1.]: University of California Press, 1986. v. 349. Citado 3 vezes nas páginas 85, 86 e 154.

GOLDENFELD, N.; KADANOFF, L. P. Simple lessons from complexity. Science, v. 284, n. 5411, p. 87-89, 1999. Citado na página 74.

GRIBKOVSKAIA, I.; HALSKAU, Ø. S.; LAPORTE, G. The bridges of königsberg - a historical perspective. Networks: An International Journal, v. 49, n. 3, p. 199-203, 2007. Citado na página 110.

HUG, B.; REESE, G. How technology integration in mathematics and science teaching can occur: the role of the maverick teacher. Teaching Education, v. 17, n. 2, p. 167-179, 2006. Citado na página 127.

HUNT, E.; MINSTRELL, J. A cognitive approach to the teaching of physics. In: Cambridge, MA: MIT Press, Bradford books, 1994. p. 51-74. Citado na página 93.

IES. 2020. <https://ies.ed.gov/> Acesso em: 28-01-2020. Citado na página 123.

JODELET, D. Social representations: The beautiful invention. Journal for the Theory of Social Behaviour, v. 38, n. 4, p. 411-430, 2008. Citado na página 140.

JONES, M. P. Networked success and failure at hybritech. Bulletin of Science, Technology E6 Society, v. 31, n. 6, p. 448-459, 2011. Citado na página 127.

JOVCHELOVITCH, S. Knowledge in context: Representations, community and culture. [S.l.]: Routledge, 2006. Citado na página 139.

KIVELÄ, M. et al. Multilayer networks. Journal of Complex Networks, v. 2, n. 3, p. 203-271, 2014. Citado na página 191.

KUHN, T. S. The Structure of Scientific Revolutions Vol. Chicago, IL: University of Chicago Press, 1962. Citado na página 92.

KURTZ, C. F.; SNOWDEN, D. J. The new dynamics of strategy: Sense-making in a complex and complicated world. IBM Systems Journal, v. 42, n. 3, p. 462-483, 2003. Citado 5 vezes nas páginas 80, 81, 82, 169 e 192.

LADYMAN, J.; LAMBERT, J.; WIESNER, K. What is a complex system? European Journal for Philosophy of Science, v. 3, n. 1, p. 33-67, 2013. Citado 5 vezes nas páginas $75,76,77,91$ e 104.

LADYMAN, J. et al. Everything Must Go: Information-Theoretic Structural Realism. [S.l.]: Oxford: Oxford University Press, 2006. Citado na página 66.

LAKATOS, I. Falsification and the methodology of scientific research programmes. In: . Criticism and the growth of knowledge. Cambridge: Cambridge University Press,

1970. Citado na página 92. 
LAKOFF, G.; JOHNSON, M. Metaphors we live by. [S.l.]: University of Chicago Press, 2008. Citado na página 64.

LATOUR, B.; HERMANDT, E. Redes que a razão desconhece: laboratórios, bibliotecas, coleções. In: Tramas da Rede. Porto Alegre, RS: Sulina, 2013. cap. 2, p. 39-63. Citado 6 vezes nas páginas 41, 99, 101, 103, 105 e 155.

LÊ, S. et al. Factominer: an R package for multivariate analysis. Journal of Statistical Software, v. 25, n. 1, p. 1-18, 2008. Citado na página 177.

LEWIN, K. Principles of topological psychology. New York, NY: McGraw-Hill Book Company Inc., 1936. Citado na página 148.

LIRA, A.; CERQUEIRA, E. C.; GOMES, C. A. As relações interpessoais entre adolescentes: o teste sociométrico como recurso para superar conflitos e violências escolares. Revista Brasileira de Psicodrama, v. 24, n. 1, p. 24-33, 2016. Citado 2 vezes nas páginas 151 e 173.

LOTKA, A. J. Analytical note on certain rhythmic relations in organic systems. Proceedings of the National Academy of Sciences, v. 6, n. 7, p. 410-415, 1920. Citado na página 69.

MACBETH, D. Hugh mehan's learning lessons reconsidered: On the differences between the naturalistic and critical analysis of classroom discourse. American Educational Research Journal, v. 40, n. 1, p. 239-280, 2003. Citado na página 36.

MARINEAU, R. Jacob Levy Moreno, 1889-1974: Father of psychodrama, sociometry, and group psychotherapy. [S.l.]: Routledge, 1989. Citado na página 149.

MARTINEZ, A. et al. Combining qualitative evaluation and social network analysis for the study of classroom social interactions. Computers $\&$ Education, v. 41, n. 4, p. 353-368, 2003. Citado 2 vezes nas páginas 157 e 165.

MATTOS, M. C.; DUDLEY, P. Uma introdução à tectologia de bogdanov: Reflexões para a transdisciplinaridade? Prisma.com, n. 18, p. 4-24, 2012. Citado na página 71.

MEHAN, H. Learning lessons. [S.l.]: Harvard University Press Cambridge, MA, 1979. Citado na página 37.

MELO, E.; TENÓRIO, A.; ACCIOLY, H. Representações sociais de ciência de um grupo de licenciandos em física. Revista Electrónica de Enseñanza de las Ciencias, v. 9, n. 2, p. 457-466, 2010. Citado na página 144.

MELO, P. T. N. B.; REGIS, H. P. Capital social nos estudos organizacionais brasileiros. In:__. Análise de Rdes Sociais em Contextos Organizacionais. Salvador, BA: Editora da Universidade Federal da Bahia, 2015. cap. 3, p. 85-117. Citado na página 152.

MERTEN, T. O teste de associação de palavras na psicologia e psiquiatria: história, método e resultados. Análise Psicológica, v. 10, p. 531-541, 1992. Citado na página 145.

MITCHELL, M. Complex systems: Network thinking. Artificial Intelligence, v. 170, n. 18, p. 1194-1212, 2006. Citado 2 vezes nas páginas 89 e 162.

MOLINER, P. L'étude éxperimentale des processus représentationnels-commentaire de 
l'article de r. michit. Papers on social representations, v. 3, n. 2, 1994. Citado 2 vezes nas páginas 145 e 183.

MORENO, J. L. Who shall survive? a new approach to the problem of human interrelations. Nervous and Mental Disease Publishing co., 1934. Citado 3 vezes nas páginas 57, 149 e 165.

MORIN, E. Introdução ao pensamento complexo. 5. ed. Porto Alegre, RS: Sulina, 2015. Citado 2 vezes nas páginas 65 e 67.

MOSCOVICI, S. A psicanálise, sua imagem e seu público. Rio de Janeiro, RJ: Zahar, 1978. Citado 6 vezes nas páginas 57, 136, 137, 139, 164 e 183.

MOSCOVICI, S. Notes towards a description of social representations. European Journal of Social Psychology, v. 8, n. 3, 1988. Citado 4 vezes nas páginas 138, 140, 141 e 183.

MOSCOVICI, S. Representações Sociais: investigações em Psicologia Social. Petrópolis, RS: Vozes, 2015. Citado 2 vezes nas páginas 137 e 141.

MUSSO, P. A filosofia da rede. In: Tramas da Rede. Porto Alegre, RS: Sulina, 2013. cap. 1, p. 17-38. Citado 7 vezes nas páginas 96, 97, 99, 107, 122, 157 e 165.

NASH, P.; SHAFFER, D. W. Mentor modeling: The internalization of modeled professional thinking in an epistemic game. Journal of Computer Assisted Learning, v. 27, n. 2, p. 173-189, 2011. Citado 2 vezes nas páginas 127 e 131.

NICHOLAS, H.; NG, W. Fostering online social construction of science knowledge with primary pre-service teachers working in virtual teams. Asia-Pacific Journal of Teacher Education, v. 37, n. 4, p. 379-398, 2009. Citado na página 127.

OLIVEIRA, D. C. et al. Futuro e liberdade: o trabalho e a instituição escolar nas representações sociais de adolescentes. Estudos de psicologia, v. 6, n. 2, 2001. Citado na página 144.

OLIVEIRA, P. M. C. Autômatos celulares. In: Complexidade e Caos. Rio de Janeiro, RJ: UFRJ Editora, 2008. cap. 9, p. 83-93. Citado na página 78.

OPPENHEIMER, F. Exploratorium: The Museum of Science, Art and Human Perception. 1969. <https://www.exploratorium.edu/>. Acesso em: 09-02-2020. Citado na página 27.

PERINO, A. et al. Rewilding complex ecosystems. Science, v. 364, n. 6438, p. 1-8, 2019. Citado na página 107.

POSNER, G. J. et al. Accommodation of a scientific conception: Toward a theory of conceptual change. Science Education, v. 66, n. 2, p. 211-227, 1982. Citado 2 vezes nas páginas 91 e 92.

PUCINELLI, R. H.; GIORDAN, M. Aplicação da análise de redes sociais em fórum de discussão de professores de ciências em formação. Enseñanza De Las Ciencias: Revista De Investigación Y Experiencias Didácticas, n. Extra, p. 1631-1636, 2017. Citado 5 vezes nas páginas 57, 157, 158, 165 e 166.

$\mathrm{R}$ - Core Team. R: A Language and Environment for Statistical Computing. Vienna, Austria, 2008. Disponível em: <http://www.R-project.org >. Citado na página 171. 
RAICHE, G.; MAGIS, D.; RAICHE, M. G. Package 'nfactors'. Parallel Analysis and Non Graphical Solutions to the Cattell Scree Test, 2010. Disponível em: $<$ https://cran.r-project.org/web/packages/nFactors/>. Citado na página 177.

RATINAUD, P. Interface de $R$ pour les Analyses Multidimensionnelles de Textes et de Questionnaires. 2008. Disponível em: <http://www.iramuteq.org/>. Citado na página 171.

RAUCH, F. et al. Profiles networks: Three international examples. Science Education International, v. 25, n. 2, p. 97-114, 2014. Citado na página 127.

RIBEIRO, M. L.; JUTRAS, F. Representações sociais de professores sobre afetividade. Estudos de Psicologia, v. 23, n. 1, p. 39-45, 2006. Citado na página 144.

RODRIGUES, E.; BORGES, A.; PIETROCOLA, M. The use of history of science on physics teaching as a social representation from pre-service teachers. Journal of Physics: Conference Series, v. 1287, n. 1, p. 012044, 2019. Citado 3 vezes nas páginas 33, 164 e 172.

RODRIGUES, E.; PIETROCOLA, M. Between social and semantic networks: A case study on classroom complexity. Education Sciences, v. 10, n. 2, p. 30, 2020. Citado 10 vezes nas páginas 33, 161, 166, 172, 175, 176, 177, 179, 180 e 182.

RODRIGUES, E. V. Uma revisão da questão da garrafa pet da prova enem 2013. Caderno Brasileiro de Ensino de Fúsica, v. 31, n. 2, p. 421-428, 2014. Disponível em: $<$ https://periodicos.ufsc.br/index.php/fisica/article/view/2175-7941.2014v31n2p421>. Citado na página 27.

RODRIGUES, E. V. Utilização de um programa de gravação e edição de áudio para discussão das características do som. In: Anais do Congreso Iberoamericano de Ciencia, Tecnología, Innovación y Educación. Buenos Aires, Argentina: [s.n.], 2014. Disponível em: $<$ www.oei.es/historico/congreso2014/memoriactei/1005.pdf > . Citado na página 27.

RODRIGUES, E. V.; CAMILETTI, G. Levantamento de concepções e atitudes dos alunos em acústica. In: Anais do X ENPEC - Encontro de Pesquisa em Ensino de Ciências. Águas de Lindóia, SP: [s.n.], 2015. Disponível em: <http://www.abrapecnet.org.br/enpec/x-enpec/anais2015/resumos/R1009-1.PDF>. Citado na página 29.

RODRIGUES, E. V.; CAMILETTI, G. Análise de redes como ferramenta exploratória da ecologia conceitual em um tópico da física. In: Anais do XI ENPEC - Encontro de Pesquisa em Ensino de Ciências. Florianópolis, SC: [s.n.], 2017. Disponível em: $<$ http://www.abrapecnet.org.br/enpec/xi-enpec/anais/resumos/R0874-1.pdf>. Citado na página 31.

RODRIGUES, E. V.; CAMILETTI, G. G. Análise estrutural de redes semânticas: um estudo exploratório das relações entre representações proposicionais e evolução conceitual em um tópico da física. Investigações em Ensino de Ciências, v. 23, n. 2, p. 211-227, 2018. Citado 4 vezes nas páginas 31, 57, 94 e 163.

RODRIGUES, E. V.; LAVINO, D. Modelagem no ensino de física via produção de stop motion, com o computador raspberry pi. Revista Brasileira de Ensino de Física, v. 42, n. 1, 2020. Citado na página 28. 
RODRIGUES, E. V.; PIETROCOLA, M. Emergência de redes sociais numa sala de aula de física, por critérios sociométricos. In: Anais do XII ENPEC Encontro de Pesquisa em Ensino de Ciências. Natal, RN: [s.n.], 2019. Disponível em: $<$ http://abrapecnet.org.br/enpec/xii-enpec/anais/resumos/1/R2135-1.pdf>. Citado na página 33.

RODRIGUES, E. V. et al. An affordable apparatus for fine-controlled emulation of buzzing frequencies of bees for the testing hypothesis in buzz interactions. Ecology and Evolution, v. 8, n. 15, p. 7667-7672, 2018. Citado na página 29.

RODRIGUES, E. V.; TELES, H. R.; CAMILETTI, G. "é só pra ver ou pode mexer?" abordagem hands-on numa sala de acústica e feedback dos visitantes. Caderno Brasileiro de Ensino de Fúsica, v. 35, n. 2, p. 660-677, 2018. Citado na página 28.

ROGERS, M. Contextualizing theories and practices of bricolage research. The Qualitative Report, v. 17, n. 48, p. 1-17, 2012. Citado na página 55.

RUIZ-PRIMO, M. A.; SHAVELSON, R. J. Problems and issues in the use of concept maps in science assessment. Journal of Research in Science Teaching: The Official Journal of the National Association for Research in Science Teaching, v. 33, n. 6, p. 569-600, 1996. Citado na página 31.

RUSSELL, P. F.; RAO, T. R. On habitat and association of species of anopheline larvae in south-eastern madras. Journal of the Malaria Institute of India, v. 3, n. 1, p. 153-178, 1940. Citado na página 171.

RYU, S.; LOMBARDI, D. Coding classroom interactions for collective and individual engagement. Educational Psychologist, v. 50, n. 1, p. 70-83, 2015. Citado 2 vezes nas páginas 127 e 130.

SÁ, C. P. Representações sociais: teoria e pesquisa do núcleo central. Temas em Psicologia, v. 4, n. 3, p. 19-33, 1996. Citado na página 143.

SÁ, C. P. A construção do objeto de pesquisa em representações sociais. Rio de Janeiro, RJ: EdUERJ, 1998. Citado na página 143.

SANTOS, G. L. A tecnologia, a ciência e seus modos de produção: representações de professores do ensino fundamental. Linhas Críticas, v. 13, n. 24, p. 21-36, 2007. Citado na página 144.

SAXE, G. B.; ESMONDE, I. Cultural development of mathematical ideas: Papua New Guinea studies. [S.l.]: Cambridge University Press, 2012. Citado 2 vezes nas páginas 156 e 157.

SAXE, G. B. et al. A methodological framework and empirical techniques for studying the travel of ideas in classroom communities. In: Transformation of knowledge through classroom interaction. [S.1.]: Routledge London, UK, 2009. p. 203-222. Citado 5 vezes nas páginas 154, 155, 157, 167 e 187.

SCHIZAS, D.; KATRANA, E.; STAMOU, G. Introducing network analysis into science education: Methodological research examining secondary school students' understanding of "decomposition". International Journal of Environmental and Science Education, v. 8, n. 1, p. 175-198, 2013. Citado 2 vezes nas páginas 127 e 130. 
SCOTT, J. Social network analysis: developments, advances, and prospects. Social Network Analysis and Mining, v. 1, n. 1, p. 21-26, 2011. Citado 4 vezes nas páginas 148, 149,150 e 162.

SEMEGEN, D. Art-tickle: points to ponder. Perspectives of New Music, v. 31, n. 1, p. 220-222, 1994. Citado na página 62.

SENGUPTA-IRVING, T. Affinity through mathematical activity: Cultivating democratic learning communities. Journal of Urban Mathematics Education, v. 7, n. 2, p. 31-54, 2014. Citado 6 vezes nas páginas 57, 152, 153, 157, 162 e 165.

SEWELL, W. H. J. Logics of history: Social theory and social transformation. Chicago, IL: University of Chicago Press, 2005. Citado 3 vezes nas páginas 84, 137 e 154.

SHIELDS, R. Cultural topology: The seven bridges of königsburg, 1736. Theory, Culture Ef Society, v. 29, n. 4-5, p. 43-57, 2012. Citado 2 vezes nas páginas 110 e 111.

SILVA, M. M.; REGIS, H. P. Perspectiva histórica da análise de redes sociais. In: Análise de redes sociais em contextos organizacionais. Salvador, BA: EDUFBA, 2015. cap. 1, p. 23-40. Citado na página 146.

STELLA, M. Forma mentis networks reconstruct how italian high schoolers and international stem experts perceive teachers, students, scientists, and school. Education Sciences, v. 10, n. 1, p. 17, 2020. Citado na página 170.

STELLA, M.; KENETT, Y. N. Viability in multiplex lexical networks and machine learning characterizes human creativity. Big Data and Cognitive Computing, v. 3, n. 3, p. 45, 2019. Citado 2 vezes nas páginas 170 e 191.

STELLA, M. et al. Forma mentis networks quantify crucial differences in stem perception between students and experts. PloS One, v. 14, n. 10, 2019. Citado na página 184.

STRIKE, K. A.; POSNER, G. J. A revisionist theory of conceptual change. In: Philosophy of science, cognitive psychology, and educational theory and practice. [S.l.]: State University of New York Press, 1992. p. 147-176. Citado na página 94.

TABER, K. S. The use of cronbach's alpha when developing and reporting research instruments in science education. Research in Science Education, v. 48, n. 6, p. 1273-1296, 2018. Citado na página 181.

TANG, K.-Y.; TSAI, C.-C. The intellectual structure of research on educational technology in science education (etise): A co-citation network analysis of publications in selected journals (2008-2013). Journal of Science Education Technology, v. 25, p. 327-344, 2016. Citado na página 127.

TANG, K.-Y. et al. The intellectual structure of metacognitive scaffolding in science education: a co-citation network analysis. International Journal of Science and Mathematics Education, v. 14, n. 2, p. 249-262, 2016. Citado na página 127.

TEIXEIRA, G. M. et al. Complex semantic networks. International Journal of Modern Physics C, v. 21, n. 03, p. 333-347, 2010. Citado na página 163.

TOBIN, K. In search of new lights: Getting the most from competing perspectives. Cultural Studies of Science Education, v. 3, p. 227-230, 2008. Citado na página 49. 
TOBIN, K. Making the most of difference. Cultural Studies? Critical Methodologies, v. 10, n. 5, p. 406-408, 2010. Citado na página 56.

TOULMIN, S. E. The evolutionary development of natural science. American Scientist, v. 55, n. 4, p. 456-471, 1967 . Citado na página 93.

VARZI, A. Mereology. 2003. Disponível em: <https://plato.stanford.edu/entries/ mereology $/>$. Citado na página 64.

VAZ, G. J. A construção dos sociogramas e a teoria dos grafos. Revista Brasileira de Psicodrama, v. 17, n. 2, p. 67-78, 2009. Citado na página 149.

VEGA-PONS, S.; RUIZ-SHULCLOPER, J. A survey of clustering ensemble algorithms. International Journal of Pattern Recognition and Artificial Intelligence, v. 25, n. 03, p. 337-372, 2011. Citado na página 119.

VERNADSKY, V. I. The biosphere and the noosphere. American Scientist, v. 33, n. 1, p. 1-12, 1945. Citado na página 45.

VICECONTI, M.; HUNTER, P.; HOSE, R. Big data, big knowledge: big data for personalized healthcare. IEEE journal of biomedical and health informatics, v. 19, n. 4, p. 1209-1215, 2015. Citado na página 53.

VOLTERRA, V. Variatzioni e fluttuazioni del numero d'individui in specie animali conviventi. Roma, IT: Accademianazionale dei Lincei, 1927. Citado na página 69.

VOSNIADOU, S.; BREWER, W. F. Mental models of the earth: A study of conceptual change in childhood. Cognitive Psychology, v. 24, n. 4, p. 535-585, 1992. Citado na página 92.

VYGOTSKY, L. S. Thought and Language. Cambridge, MA: Cambridge University Press, 1986. Citado na página 167.

WATANABE, G. et al. Complexidade e ensino de física: o uso da teoria de grafos na análise do processo de ensino-aprendizagem. Enseñanza De Las Ciencias, n. Extra, p. 4467-4472, 2017. Citado na página 57.

WISER, M. Use of history of science to understand and remedy students' misconceptions about heat and temperature. Software goes to school: Teaching for understanding with new technologies, Oxford University Press New York, NY, p. 23-38, 1995. Citado na página 92.

WOLD, S.; ESBENSEN, K.; GELADI, P. Principal component analysis. Chemometrics and intelligent laboratory systems, v. 2, n. 1-3, p. 37-52, 1987. Citado na página 177.

YIN, R. K. The case study as a serious research strategy. Knowledge, v. 3, n. 1, p. 97-114, 1981. Citado na página 169. 
Apêndices 


\section{APÊNDICE A - Instrumento de coleta para}

\section{TALP}

Caro aluno, este é um questionário de pesquisa. Desde já agradecemos sua participação nesse processo. Tudo que for respondido aqui será utilizado exclusivamente para fins científicos e sua identidade nãos será revelada. Portanto, você pode ser extremamente sincero em suas respostas.

Nome:

\section{Queremos saber o que você pensa!}

Escreva as cinco primeiras palavras que lhe vêm à mente quando você pensa em CALOR 01: $02:$ 03: 04: 05:

Escreva as cinco primeiras palavras que lhe vêm à mente quando você pensa em FÍSICA 01: $02:$ $03:$ 04: 05:

Escreva as cinco primeiras palavras que lhe vêm à mente quando você pensa em CIÊNCIA 01: $02:$ 03: 04: 05:

Escreva as cinco primeiras palavras que lhe vêm à mente quando você pensa em ESCOLA $01:$ $02:$ 03: 04: 05:

Escreva as cinco primeiras palavras que lhe vêm à mente quando você pensa em FUTURO 01: $02:$ 03: 04: 05: 


\section{APÊNDICE B - Instrumento sociométrico}

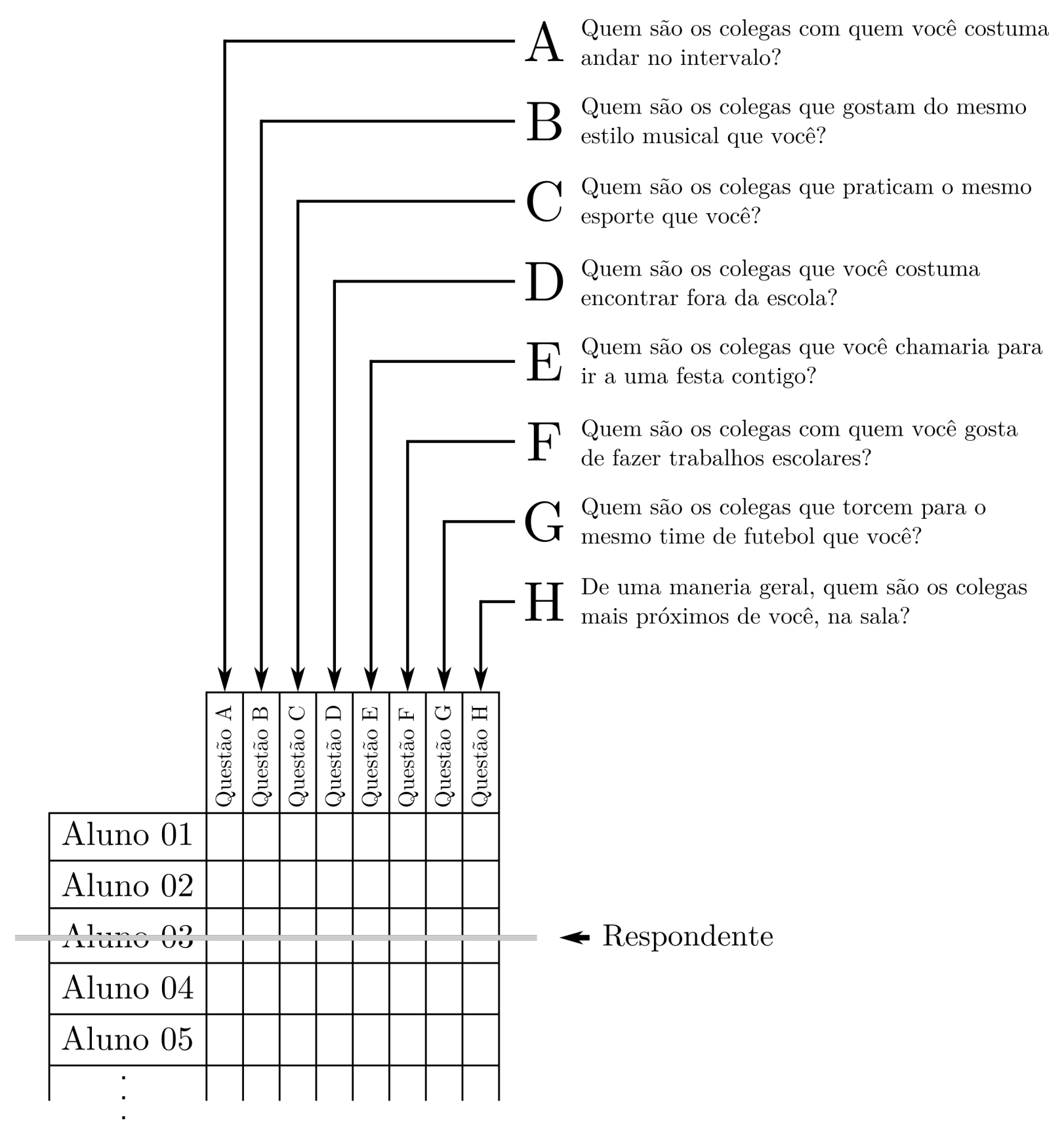




\section{APÊNDICE C - Redes sociais para cada critério sociométrico}

Constumam andar juntos no intervalo

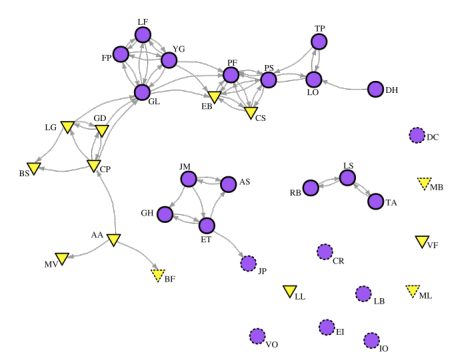

Costumam fazer trabalhos escolares juntos

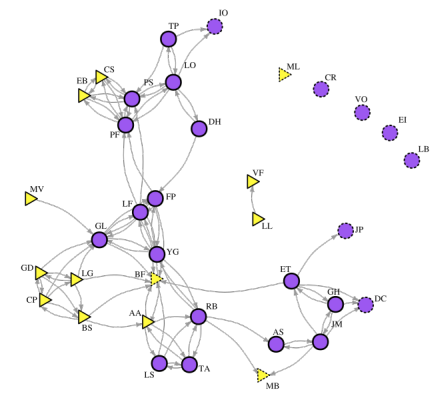

Gostam do mesmo estilo musical

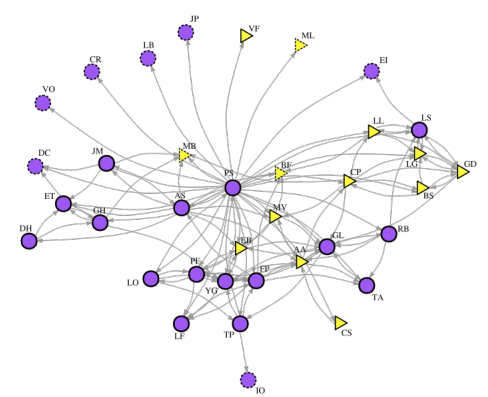

Torcem para o mesmo time de futebol

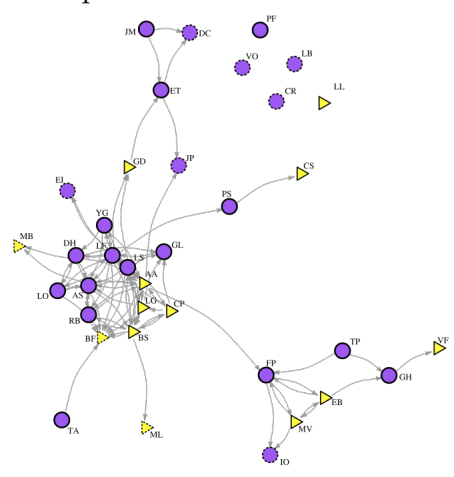

Iriam juntos a uma festa

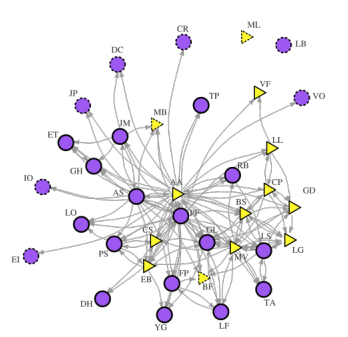

Se encontram fora da escola

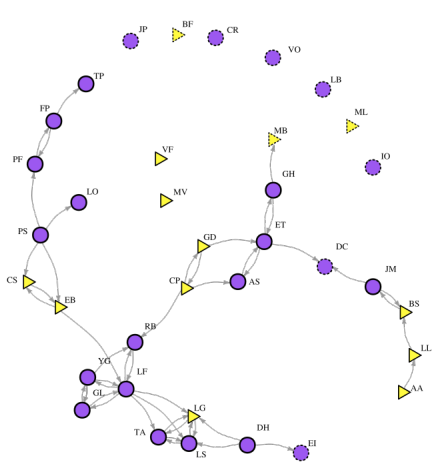

Praticam o mesmo esporte

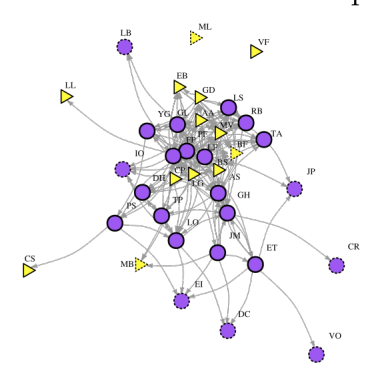

Se sentem mais próximos

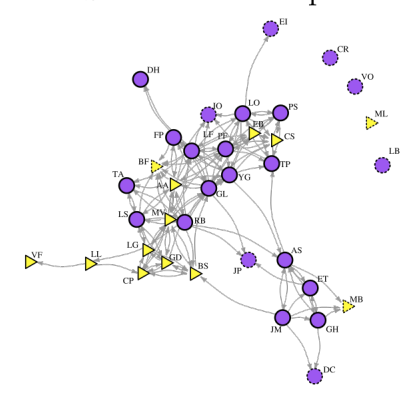




\section{APÊNDICE D - Script em R para}

\section{cientometria}

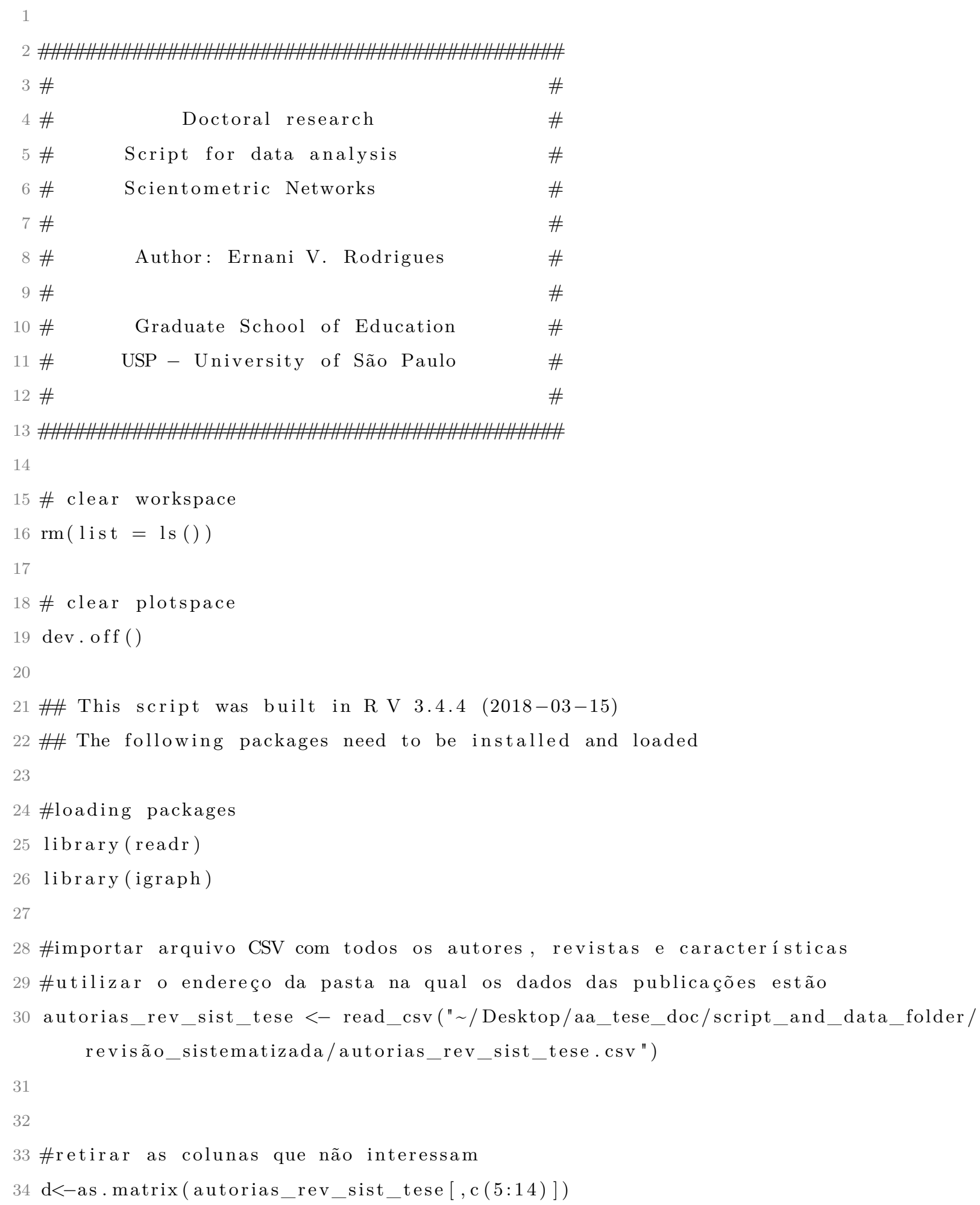


$35 \mathrm{~d}$

36

37 \#produzir, para todos os artigos, as redes híbridas de conexão entre autores, tipo de rede e aglomração em revistas

38 g1<-make_full_citation_graph $($ length $($ na.omit $(\mathrm{d}[1]))$, directed $=$ FALSE $) \% \%$

39 set_vertex_attr( "name", value $=$ na.omit $(\mathrm{d}[1])$,

40

g2<-make_full_citation_graph (length (na.omit $(\mathrm{d}[2]))$, directed $=$ FALSE) $\% \%$

set_vertex_attr("name", value = na.omit $(\mathrm{d}[2])$,

43

44 g3<-make_full_citation_graph (length $($ na.omit $(\mathrm{d}[3]))$, directed $=$ FALSE) $\% \%$

set_vertex_attr("name", value = na.omit $(\mathrm{d}[3])$,

g4<-make_full_citation_graph(length (na.omit $(\mathrm{d}[4]))$, directed $=$ FALSE) $\% \%$

set_vertex_attr("name", value = na.omit $(\mathrm{d}[4])$,

49

50 g $5<-$ make_full_citation_graph $($ length $($ na.omit $(\mathrm{d}[5]))$, directed $=$ FALSE $) \% \%$

set_vertex_attr("name", value $=$ na.omit $(\mathrm{d}[5])$,

g6 $<-$ make_full_citation_graph $($ length $($ na.omit $(d[6]))$, directed $=$ FALSE $) \% \%$

set_vertex_attr("name", value = na.omit $(\mathrm{d}[6])$,

55

56 g7 $<-$ make_full_citation_graph $($ length $($ na.omit $(\mathrm{d}[7]))$, directed $=$ FALSE $) \% \%$

set_vertex_attr("name", value $=$ na.omit $(\mathrm{d}[7])$,

g8 $8<-$ make_full_citation_graph $($ length $($ na.omit $(\mathrm{d}[8]))$, directed $=$ FALSE) $\% \%$

set_vertex_attr("name", value $=$ na.omit $(\mathrm{d}[8])$,

2 g9<-make_full_citation_graph (length $($ na.omit $(\mathrm{d}[9]))$, directed $=$ FALSE) $\% \%$

set_vertex_attr("name", value = na.omit $(\mathrm{d}[9])$,

g10<-make_full_citation_graph $($ length $($ na.omit $($ d $[10]))$, directed $=$ FALSE) $\% \%$

set_vertex_attr("name", value = na.omit $(\mathrm{d}[10])$,

67

68 g11<-make_full_citation_graph $($ length $($ na.omit $(d[11]))$, directed $=$ FALSE $) \% \%$

69 set_vertex_attr("name", value $=$ na.omit $(\mathrm{d}[11])$,

70

71 g12<-make_full_citation_graph (length $($ na.omit $(d[12]))$, directed $=$ FALSE $) \% \%$

72 set_vertex_attr ("name", value = na.omit $(\mathrm{d}[12])$,

73

74 g13<-make_full_citation_graph $($ length $($ na.omit $(d[13]))$, directed $=$ FALSE) $\% \%$

75 set_vertex_attr("name", value = na.omit $(\mathrm{d}[13])$, 
77 g14<-make_full_citation_graph $($ length $($ na.omit $(\mathrm{d}[14]))$, directed $=$ FALSE) $\% \%$

78 set_vertex_attr("name", value $=$ na.omit $(\mathrm{d}[14])$,

79

80 g15<-make_full_citation_graph $($ length $($ na.omit $(\mathrm{d}[15]))$, directed $=$ FALSE) $\% \%$

81 set_vertex_attr("name", value $=$ na.omit $(\mathrm{d}[15])$,

82

83 \#unir todas as redes de co-autoria

84 gt<-union (g1,g2, g3 ,g4,g5,g6,g7,g8,g9, g10,g11,g12,g13,g14,g15)

85

86

87 \# numero de vezes que cada autor apareceu na busca bibliográfica

$88 \mathrm{j}<-\mathrm{c}(1,1,1,3,2,1,1,1,1,2,1,1,1,1,1,1,1,1,1,1,1,1,1,1,1,1$,

$891,1,1,1,1,1,1,1,1,1,1,1,1,1,1,1,1,1,1,1,1,1,1,1,1)$

90

91 \# plotar

$92 \operatorname{plot}(\mathrm{gt}, \quad$ edge. $\operatorname{curved}=0, \quad$ vertex. $\operatorname{size}=3 * \mathrm{j})$ 


\section{APÊNDICE E - Script de R para análise das}

\section{Redes}

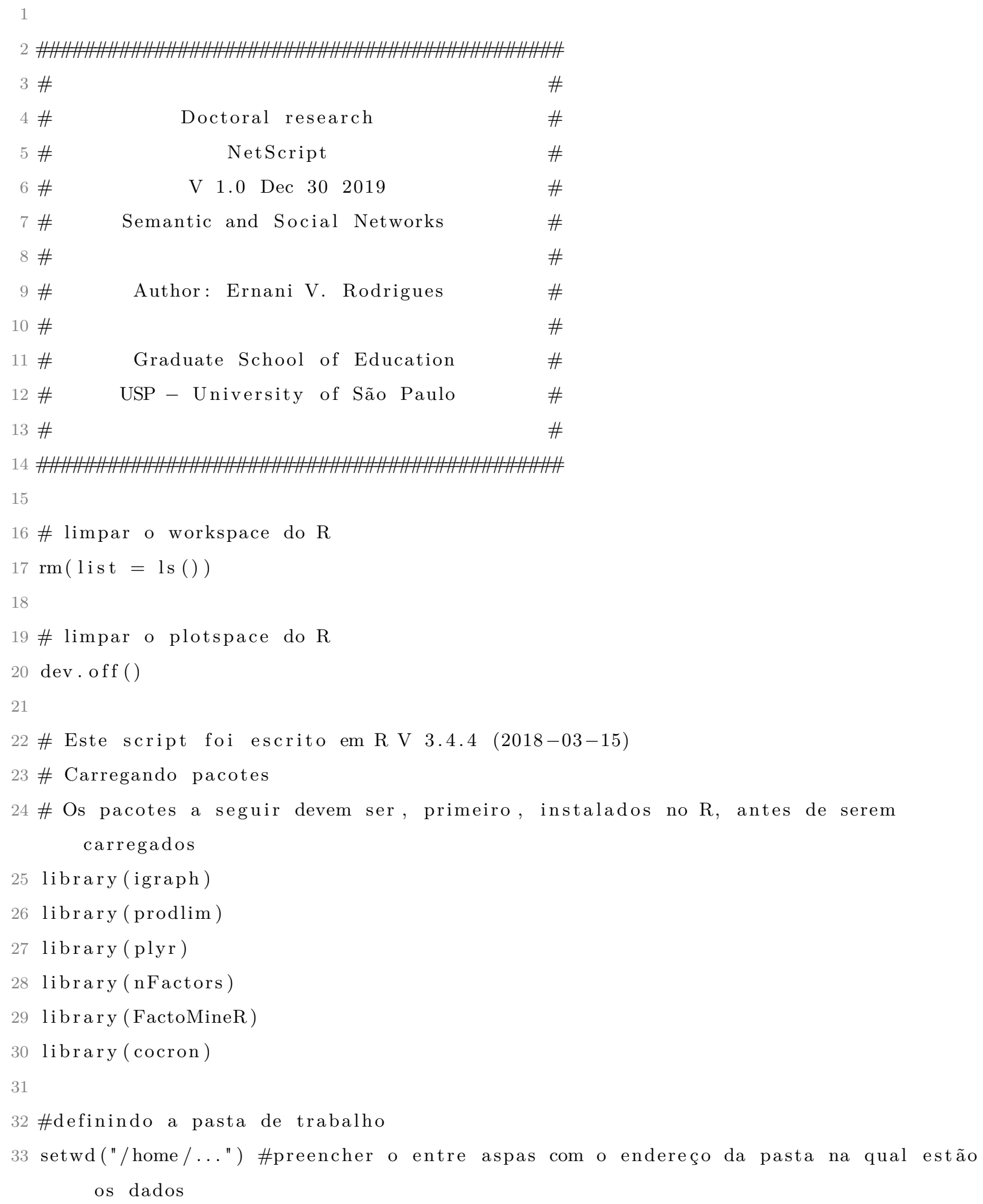


34

35 \#os dados crus estão disponíveis em https:// bit.ly/2MFeaG8

36

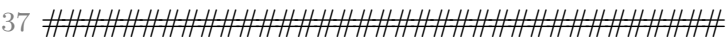

38 \#\# para as redes semânticas \#\#\#\#

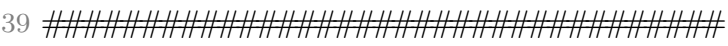

40

41

42 \#\#\#\# atividade de evocação livre

43 \#\# Os alunos evocaram livremente as 5 primeiras palavras que vêm à mente acerca de 5 termos indutores

44 \#\# Os termos indutores foram Calor, Física, Ciência, Escola e Futuro

45 \#\# No primeiro passo, o Iramuteq foi utilizado para gerar as matrizes de similaridade

46 \#entre palavras evocadas

47 \#\# O índice de similaridade de Russel foi usado como algoritmo

48 \#\# Uma matriz de similaridade $n$ X n foi usada como matriz de adjacências para o pacote Igraph

49

50 \#calor

51 ad_cal <- as.matrix (read.csv ("simi_calor.csv", header $=\mathrm{T}))$

52 ad_cal

$53 \operatorname{dim}($ ad_cal $)$

54 ad_cal<-ad_cal $[\mathrm{c}(1: 48), \mathrm{c}(2: 49)]$

$55 \operatorname{dim}\left(\operatorname{ad} \_\right.$cal $)$

56 s_cal <- graph_from_adjacency_matrix $($ ad_cal , mode $=$ " undirected " , weighted $=$ TRUE )

57 ps_cal <-E( s_cal $) \$$ weight

58 deg_cal<-degree $\left(\mathrm{s} \_\right.$cal $, \quad \mathrm{v}=\mathrm{V}\left(\mathrm{s} \_\right.$cal $), \operatorname{mode}=$ "total ", normalized $\left.=\mathrm{F}\right)$

59

$60 \operatorname{plot}\left(\mathrm{s} \_\right.$cal, vertex.size $=\left(\operatorname{deg} \_\right.$cal $\left./(2.7)\right)$, vertex.label. $\operatorname{color}=\operatorname{rgb}(0,0,0), \operatorname{edge}$. width $=\mathrm{E}\left(\mathrm{s} \_\right.$cal $) \$$ weight $* 15$,

61 edge.curved $=0.2$, vertex $\cdot \operatorname{color}=\operatorname{rgb}(194 / 255,165 / 255,207 / 255)$, edge. color $=$ rgb $(241 / 255,180 / 255,50 / 255)$, layout=layout_with_fr $)$

62

63 \#checando os vértices de maior grau e as arestas de maior similaridade

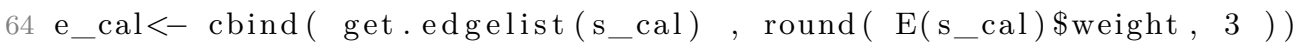

65 e_cal $<-\mathrm{e} \_$cal $\left[\operatorname{order}\left(\mathrm{e} \_\right.\right.$cal $\left.\left.[, 3]\right),\right]$

66 e_cal

67

68

69 d_cal <- as.matrix (deg_cal)

$70 \mathrm{~d} \_$cal $<-d$ d_cal $\left[\operatorname{order}\left(d_{\_} \operatorname{cal}[, 1]\right),\right]$ 


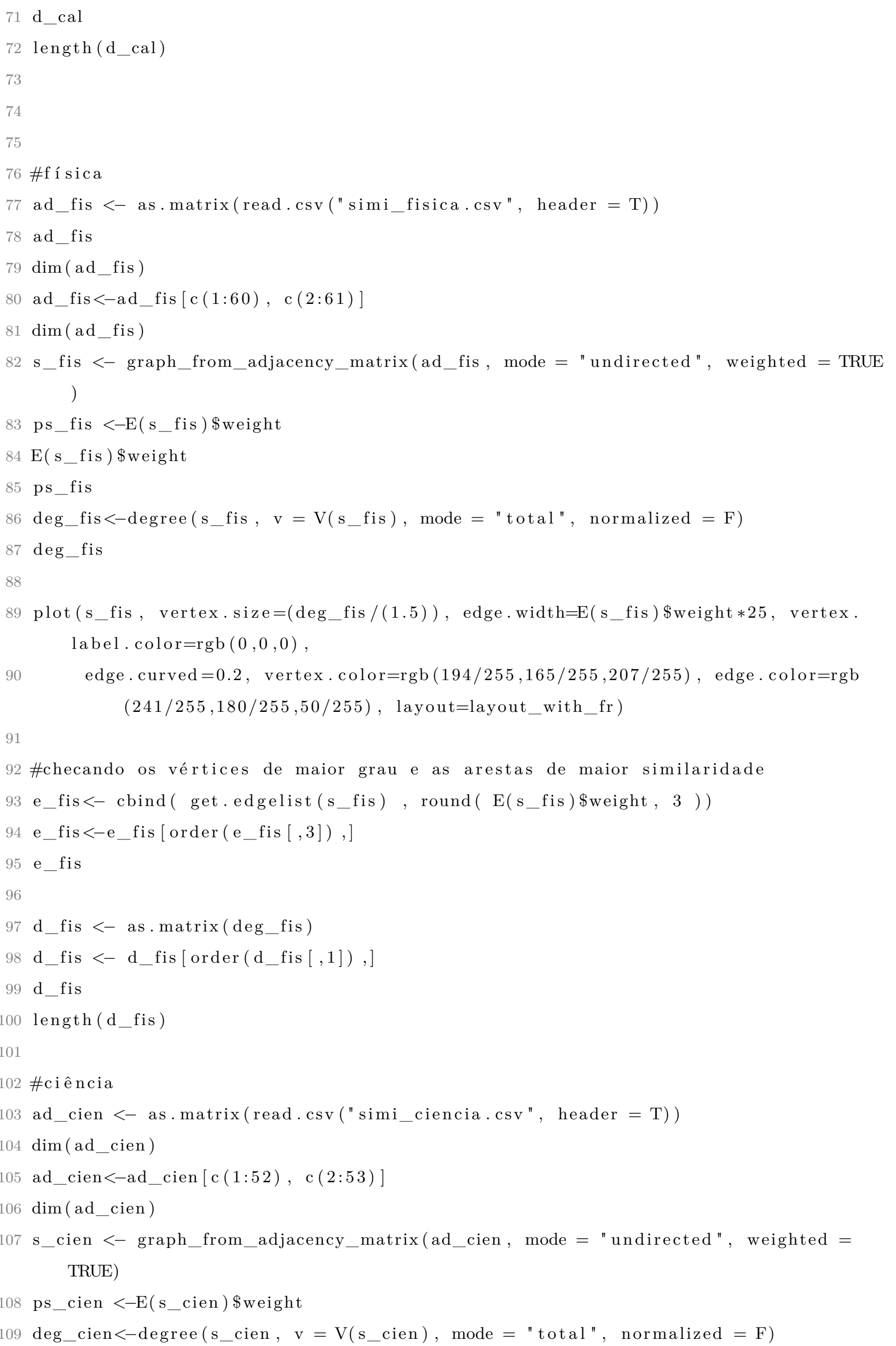




\section{0}

111 plot (s_cien, vertex.size=(deg_cien $/(1.6))$, edge.width=E(s_cien $) \$$ weigh $* 15$, vertex . label. color $=\operatorname{rgb}(0,0,0)$,

112 edge.curved $=0.2$, vertex . color $=\operatorname{rgb}(194 / 255,165 / 255,207 / 255)$, edge.color $=$ rgb $(241 / 255,180 / 255,50 / 255)$, layout=layout_with_fr $)$

113

114

115 \#checando os vértices de maior grau e as arestas de maior similaridade

116 e_cien $<-$ cbind ( get.edgelist (s_cien) , round $\left(\mathrm{E}\left(\mathrm{s} \_\right.\right.$cien $)$\$weight, 3 ))

117 e_cien $<-$ e_cien [order $\left(\mathrm{e} \_\right.$cien $\left.\left.[, 3]\right),\right]$

118 e_cien

119

120 d_cien $<-$ as . matrix $($ deg_cien $)$

121 d_cien $<-$ d_cien [order $\left(d_{\text {__cien }}[, 1]\right)$, ]

122 d_cien

123 length (d_cien)

124

125 \# escola

126 ad_esc <- as.matrix (read.csv ("simi_escola.csv", header $=\mathrm{T})$ )

$127 \operatorname{dim}\left(\mathrm{ad} \_\right.$esc $)$

128 ad_esc $<-$ ad_esc $[\mathrm{c}(1: 60), \mathrm{c}(2: 61)]$

$129 \operatorname{dim}($ ad_esc $)$

130 s_esc $<-$ graph_from_adjacency_matrix $($ ad_esc, mode $=$ " undirected ", weighted $=$ TRUE )

131 ps_esc <-E(s_esc $) \$$ weight

132 deg_esc $<-$ degree $\left(\mathrm{s} \_\right.$esc,$\quad \mathrm{v}=\mathrm{V}\left(\mathrm{s} \_\right.$esc $)$, mode $=$"total ", normalized $\left.=\mathrm{F}\right)$

133 deg_esc

134

135 plot $\left(\mathrm{s} \_\right.$esc, vertex.size $=($deg_esc $/(2.2))$, edge.width $=\mathrm{E}\left(\mathrm{s} \_\right.$esc $) \$$ weigh $* 20$, vertex . label. color $=\operatorname{rgb}(0,0,0)$,

$136 \quad$ edge.curved $=0.2$, vertex $\cdot \operatorname{color}=\operatorname{rgb}(194 / 255,165 / 255,207 / 255)$, edge. color $=$ rgb $(241 / 255,180 / 255,50 / 255)$, layout=layout_with_fr $)$

137

138 \#checando os vértices de maior grau e as arestas de maior similaridade

139 e_esc $<-$ cbind ( get.edgelist (s_esc), $\operatorname{round}\left(\mathrm{E}\left(\mathrm{s} \_\right.\right.$esc $)$\$weight, 3 ))

140 e_esc $<-$ e_esc [ order (e_esc $[, 3])$,]

141 e_esc

142

143 d_esc $<-$ as.matrix $($ deg_esc $)$

144 d_esc $<-$ d_esc $\left[\right.$ order $\left(\mathrm{d} \_\right.$esc $\left.\left.[, 1]\right),\right]$

$145 \mathrm{~d}$ _esc

146 length (d_esc) 


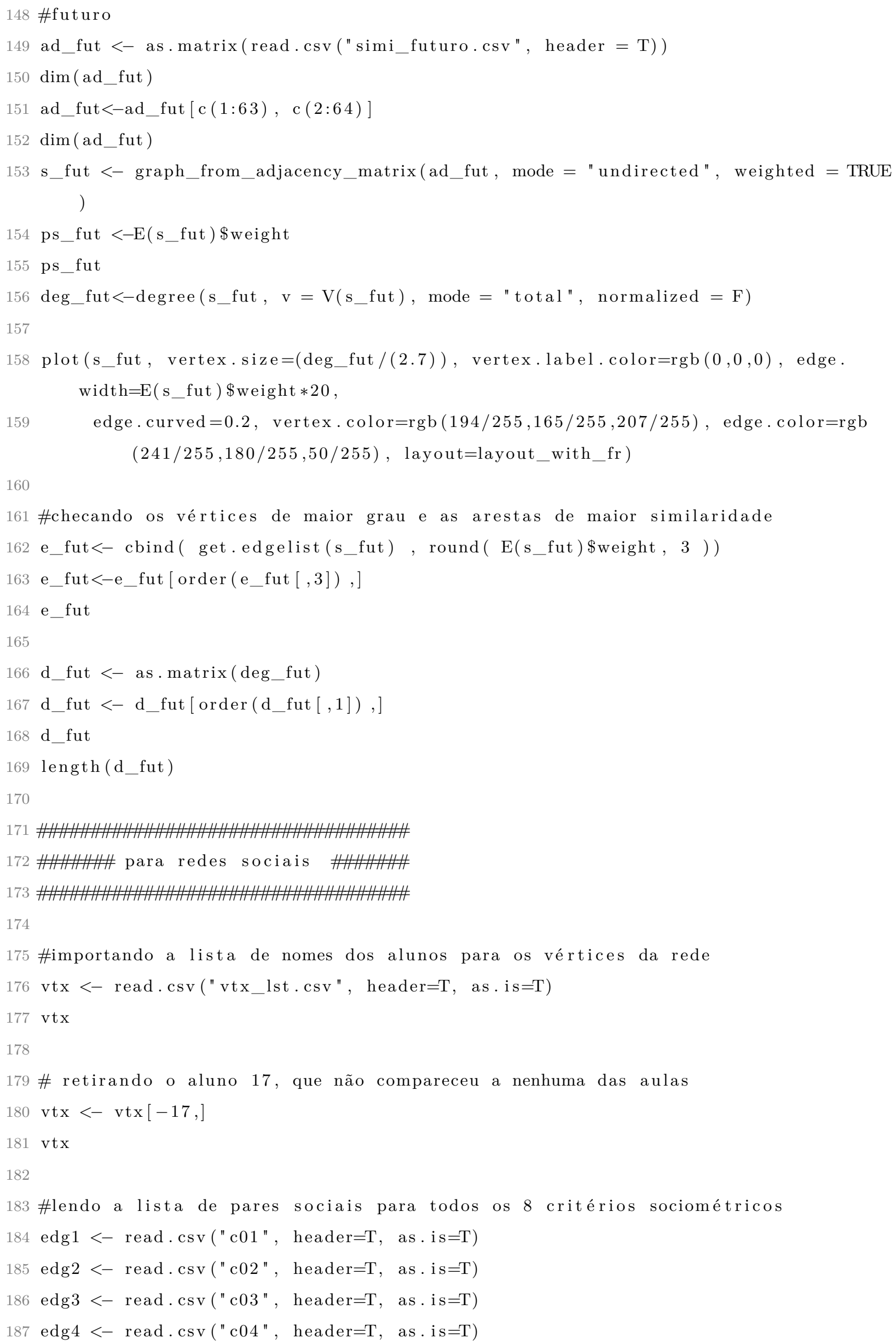




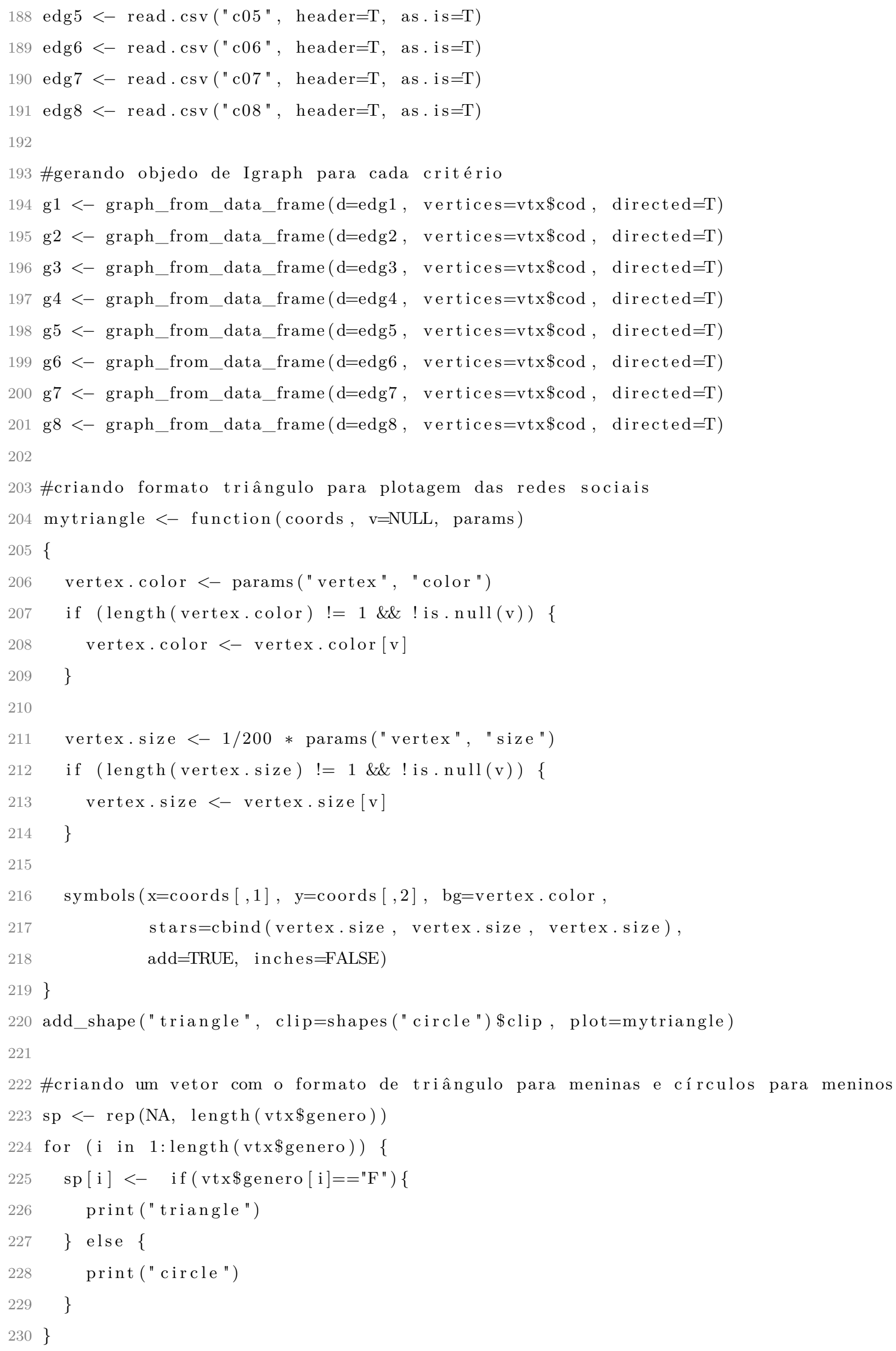




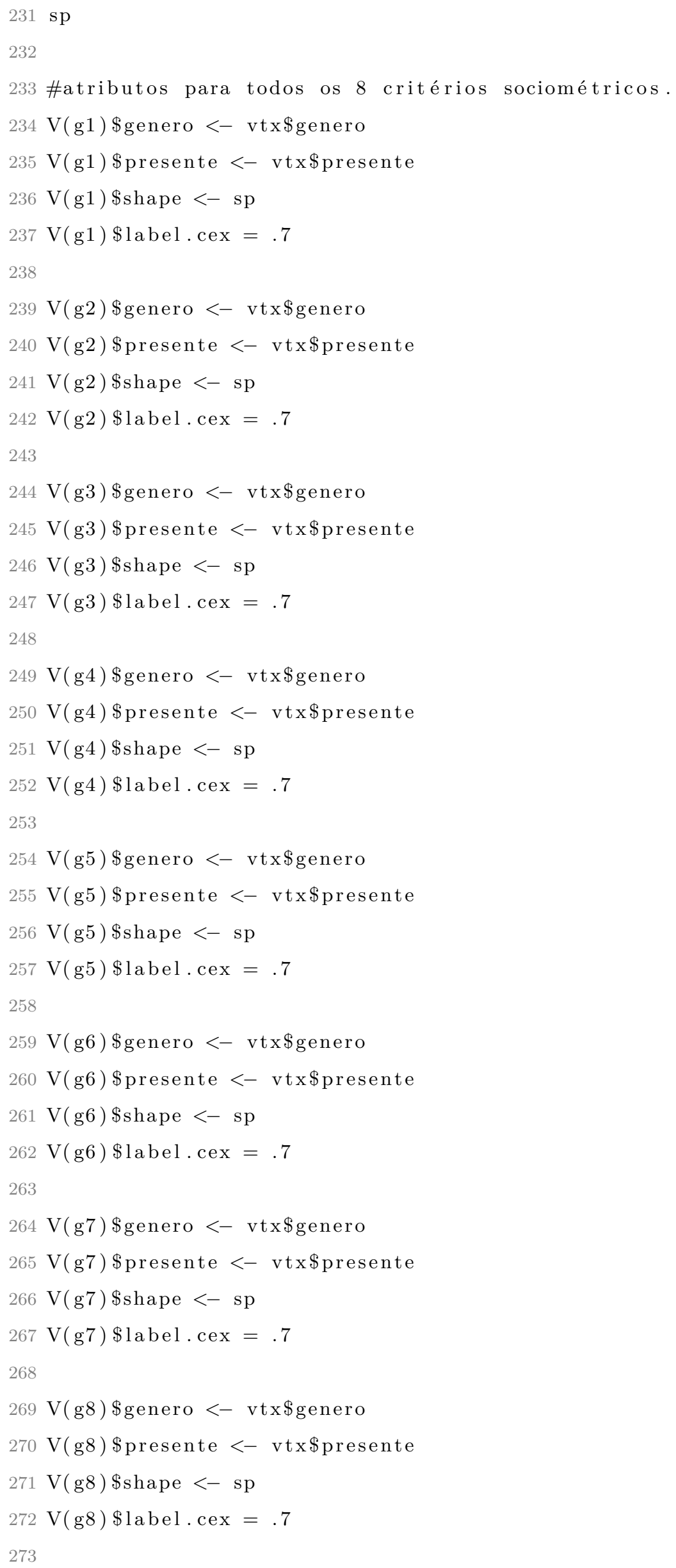


274 \#plotando a rede social para cada critério

275

276 \#critério 01

277 plot (g1, vertex.size=7, edge.arrow.size=.15, edge.curved=0.25, edge. color $="$ grey60

", vertex.label.color="black",

278 vertex $\cdot$ color $=c($ " orange ", "lightgrey ") $[1+(\mathrm{V}(\mathrm{g} 1) \$$ presente=="A" ) ],

279 main=" Intervalo ")

280

281 \#critério 02

282 plot (g2, vertex.size=7, edge.arrow.size=.15, edge.curved=0.25, edge. color $="$ grey60

", vertex.label. color $="$ black",

283 vertex $\cdot$ color $=c($ " orange ", "lightgrey ") $[1+(\mathrm{V}($ g2 $) \$$ presente=="A" ) ],

284 main=" Estilo musical ")

285

286 \#critério 03

287 plot (g3, vertex.size=7, edge.arrow.size=.15, edge.curved=0.25, edge. color $="$ grey60

", vertex.label. color="black",

288

289 vertex . color $=$ c ( "orange" , "lightgrey ") $[1+(\mathrm{V}(\mathrm{g} 3) \$$ presente=="A" ) ], main="Mesmo esporte" )

290

291 \#critério 04

292 plot (g4, vertex.size=7, edge.arrow.size=.15, edge.curved=0.25, edge. color $="$ grey60 ", vertex.label. color="black",

293

295

296 \#critério 05

297 plot (g5, vertex.size=7, edge.arrow.size $=.15$, edge.curved $=0.25$, edge. $\operatorname{color}="$ grey 60

", vertex.label . color $="$ grey $20 "$,

298

300

301 \#critério 06

302 plot (g6, vertex.size=7, edge.arrow.size=.15, edge.curved=0.25, edge. color $="$ grey60

", vertex.label. color="black",

305

306 \#critério 07

307 plot $($ g7, vertex.size $=7$, edge.arrow.size $=.15$, edge.curved $=0.25$, edge. $\operatorname{color}="$ grey 60

", vertex.label. color="black", 


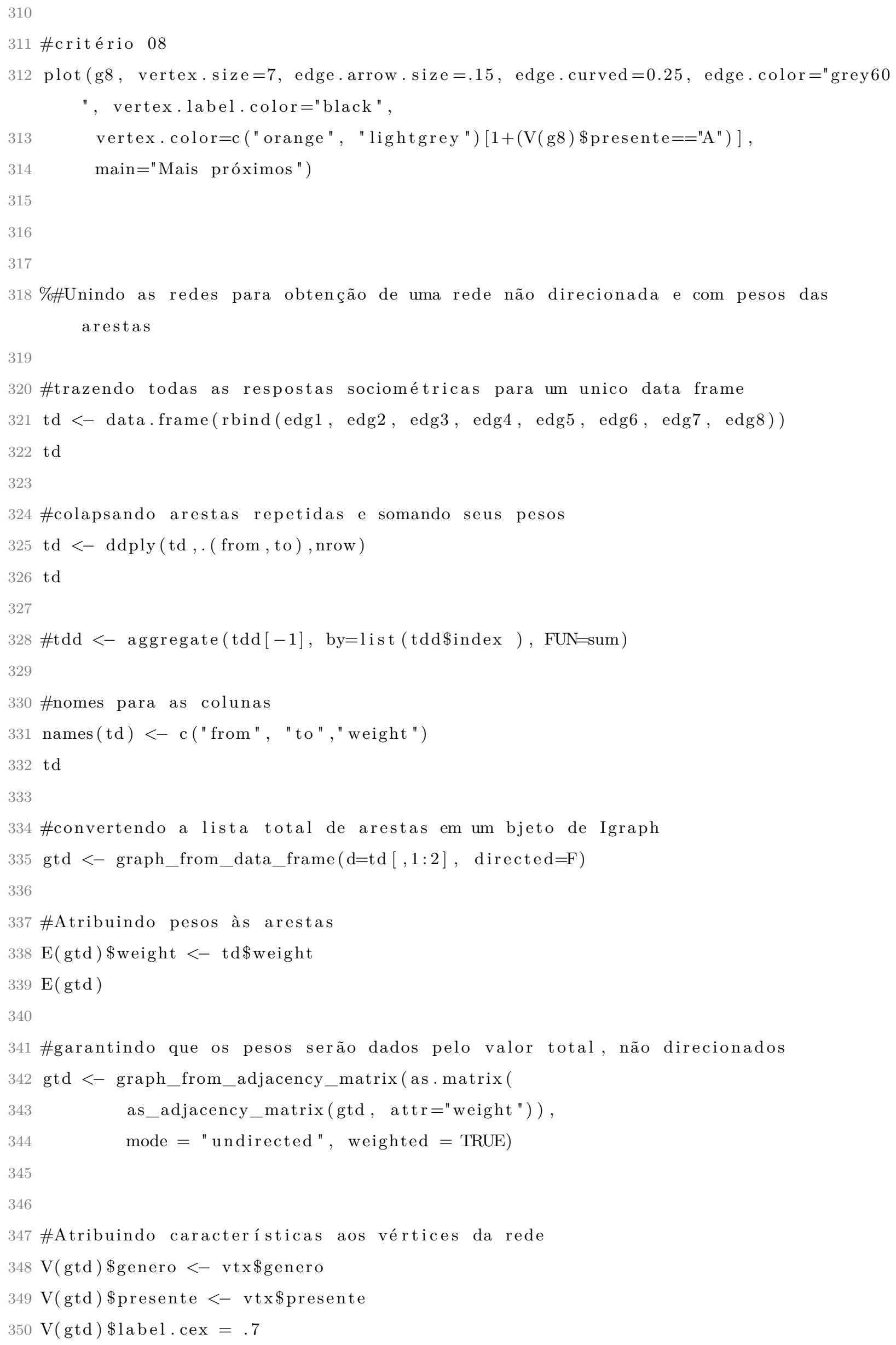




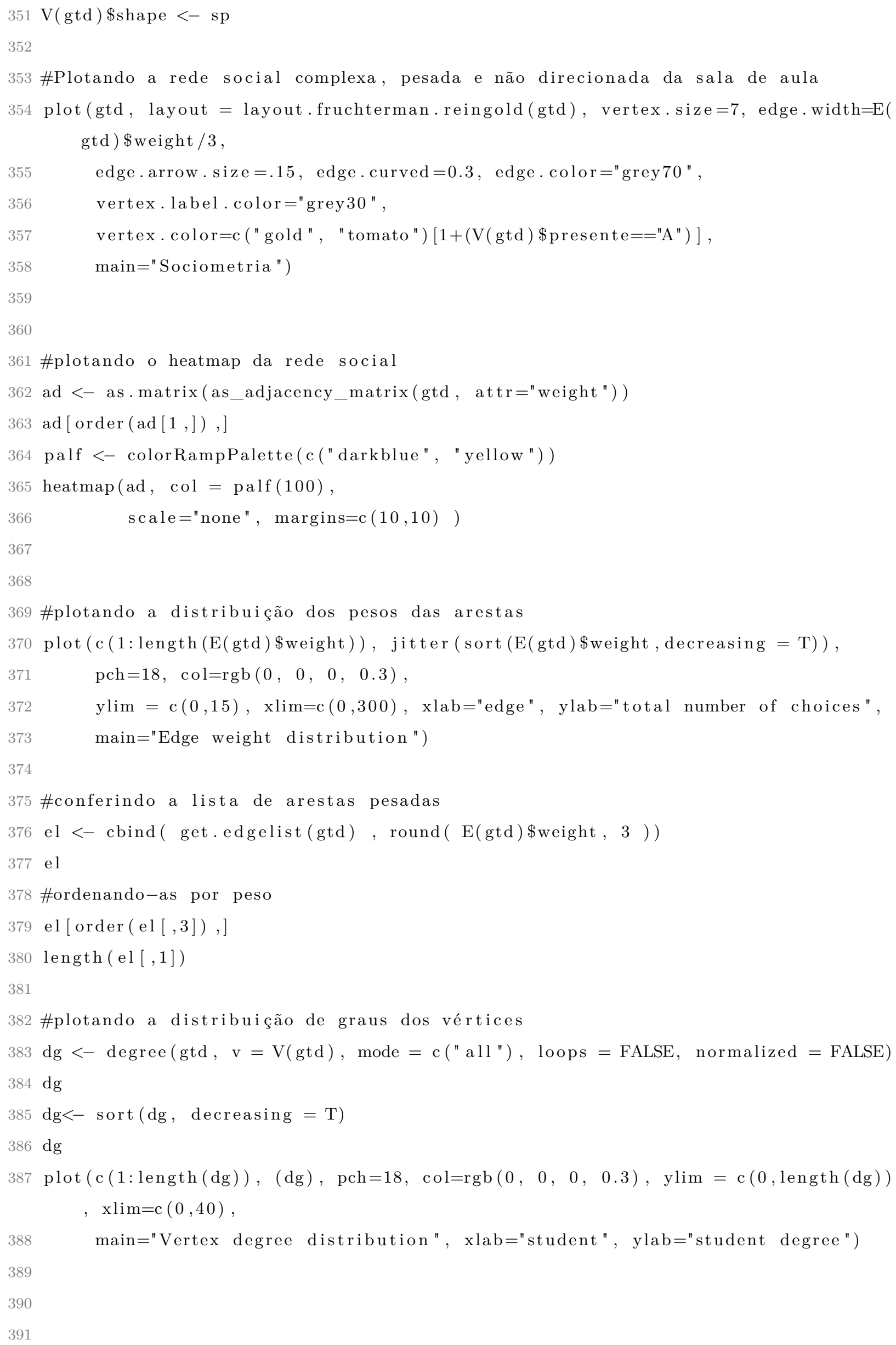




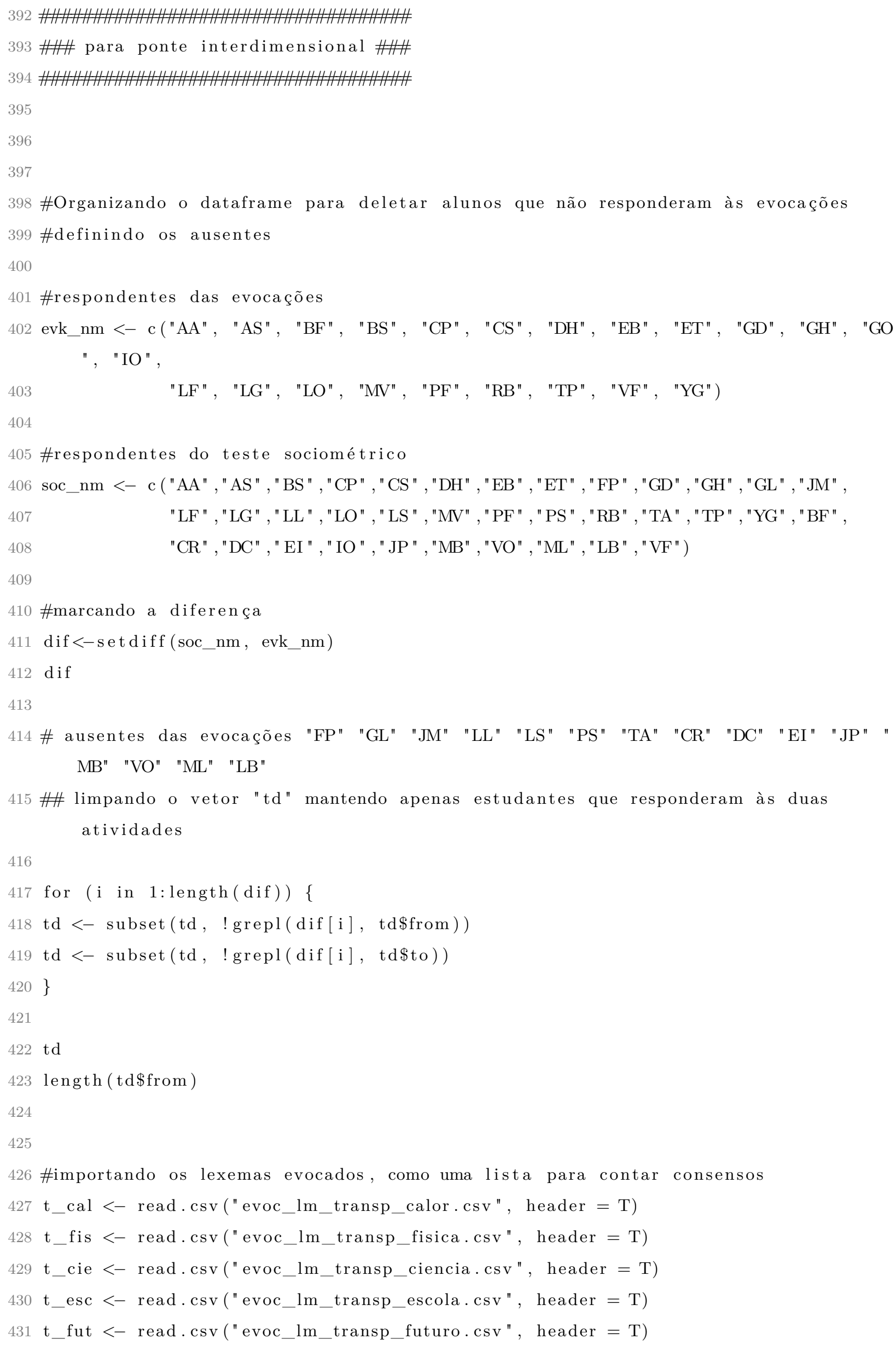


434 \#\#\#\# contando consensos para "Calor"

435 mtch_cal $<-$ c $($ rep $(N A$, length $(\operatorname{td} \$$ from $)))$

436 for ( $\mathrm{i}$ in 1 : length $(\mathrm{td} \$$ from $))\{$

$437 \quad \mathrm{k}<-$ as.character $(\operatorname{td} \$$ from $[\mathrm{i}])$

$438 \mathrm{~m}<-$ as.character $(\operatorname{td} \$$ to $[\mathrm{i}])$

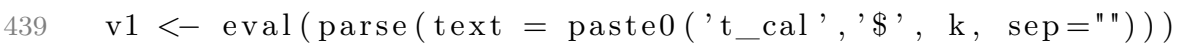

$440 \quad \mathrm{v} 1<-$ as.character $(\mathrm{v} 1)$

$441 \quad \mathrm{v} 1<-\mathrm{v} 1[\mathrm{v} 1 \quad$ != " "] 
$478\}$

479 mtch_cie $<-$ as . numeric $\left(\operatorname{mtch} \_\right.$cie $)$

480

481

482 \#\#\# contando consensos para "Escola"

483 mtch_esc $<-$ c $(\operatorname{rep}(\mathrm{NA}, \quad \operatorname{length}(\operatorname{td} \$$ from $)))$

484 for ( i in 1:length (td\$from) \{

485

486

487

488

489

490

491

492

493

$494\}$

495 mtch_esc $<-$ as .numeric (mtch_esc $)$

496

497 \#\#\# contando consensos para "Futuro"

498 mtch_fut $<-$ c $(\operatorname{rep}(\mathrm{NA}, \operatorname{length}(\mathrm{td} \$$ from $)))$

499 for ( i in 1:length (td\$from) \{

$500 \quad \mathrm{k}<-$ as. character $(\operatorname{td} \$$ from $[\mathrm{i}])$

$501 \mathrm{~m}<-$ as. character $(\mathrm{td} \$ \operatorname{to}[\mathrm{i}])$

$502 \quad \mathrm{v} 1<-\operatorname{eval}\left(\operatorname{parse}\left(\mathrm{text}=\operatorname{paste0}\left({ }^{\prime} \mathrm{t} \_f u t,, ' \$,, \mathrm{k}, \mathrm{sep}="{ }^{\prime \prime}\right)\right)\right)$

503 v1 <- as. character (v1)

$504 \quad \mathrm{v} 1<-\mathrm{v} 1[\mathrm{v} 1 \quad !=$ " "]

$505 \quad \mathrm{v} 2<-\operatorname{eval}\left(\operatorname{parse}\left(\mathrm{text}=\operatorname{paste0}\left(' \mathrm{t} \_\mathrm{fut},, \quad \$, \quad \mathrm{~m}, \quad \operatorname{sep}=" "\right)\right)\right)$

506 v2 $<-$ as. character ( v2)

$507 \quad \mathrm{v} 2<-\mathrm{v} 2[\mathrm{v} 2 \quad !=$ " "]

508

mtch_fut $[\mathrm{i}]<-$ if $(\operatorname{length}(\mathrm{v} 1)>\operatorname{length}(\mathrm{v} 2))(\operatorname{paste}(\operatorname{sum}(\mathrm{v} 1 \% \mathrm{on} \%$ v2)) $)$ else ( paste $(\operatorname{sum}(\mathrm{v} 2 \%$ in $\%$ v1))

$509\}$

510 mtch_fut $<-$ as .numeric (mtch_fut $)$

511 
513 \#adicionando a coluna com numero de "matches" aos dados

514 td $<-$ cbind $(\mathrm{td}$, mtch_cal, mtch_fis, mtch_cie, mtch_esc, mtch_fut )

$515 \mathrm{td}$

516

517 \#testando linhas que contém escolhas mutuas na rede social

$518 \mathrm{k}<-\operatorname{row} \cdot \operatorname{match}(\operatorname{td}[, \mathrm{c}(1,2)], \operatorname{td}[, \mathrm{c}(2,1)])$

$519 \mathrm{k}$

520

521 \#gerando uma coluna de índice para rodar loop

$522 \mathrm{k}<-\operatorname{cbind}(\operatorname{seq}(1: \operatorname{length}(\mathrm{k})), \mathrm{k})$

$523 \mathrm{k}$

524

525 \#\#\#rodando loop com as condições:

526 \#Se a segunda coluna de $\mathrm{k}$ for NA, repetem-se os nomes

527 \#Se a segunda coluna de $\mathrm{k}$ for menor que a primeira, tome a próxima linha e inverta os nomes

528 \# exemplo, na linha 20, inverte AS AA para AA AS

529 \#Mas, se o segundo índice é maior, mantenham o nome pois ele já fora invertido anteriormente

530

531 for (i in $1: \operatorname{length}(\mathrm{k}[, 1]))\{$

532 if (is.na $(\mathrm{k}[\mathrm{i}, 2])=\mathrm{T})\{$

$533 \operatorname{td}[\mathrm{i}, \mathrm{c}(1,2)]<-\operatorname{td}[\mathrm{i}, \mathrm{c}(1,2)]$

$534\}$ else if $(\mathrm{k}[\mathrm{i}, 1]<\mathrm{k}[\mathrm{i}, 2])\{$

$535 \operatorname{td}[\mathrm{k}[\mathrm{i}, 2], \mathrm{c}(1,2)]<-\operatorname{td}[\mathrm{k}[\mathrm{i}, 2], \mathrm{c}(2,1)]$

$536\}$ else \{

$537 \operatorname{td}[\mathrm{k}[\mathrm{i}, 1], \mathrm{c}(1,2)]<-\operatorname{td}[\mathrm{k}[\mathrm{i}, 1], \mathrm{c}(1,2)]$

$538\}$

$539\}$

540

541 \#\#)hecagem de resultado

542 td

543

544 \#\#mesclando pares repetidos e somando seus pesos de arestas

545 tdd $<-$ as.data. frame $($ td $)$

546 tdd

547

548 \#\#+\#iando uma coluna com nome do par (aresta)

549 tdd $\$$ index $<-$ paste $(\operatorname{tdd} \$$ from, tdd\$to, sep="--")

550

551 \#separando as colunas que interessam

$552 \operatorname{tdd}<-\operatorname{tdd}[, \mathrm{c}(9,3,4,5,6,7,8)]$ 


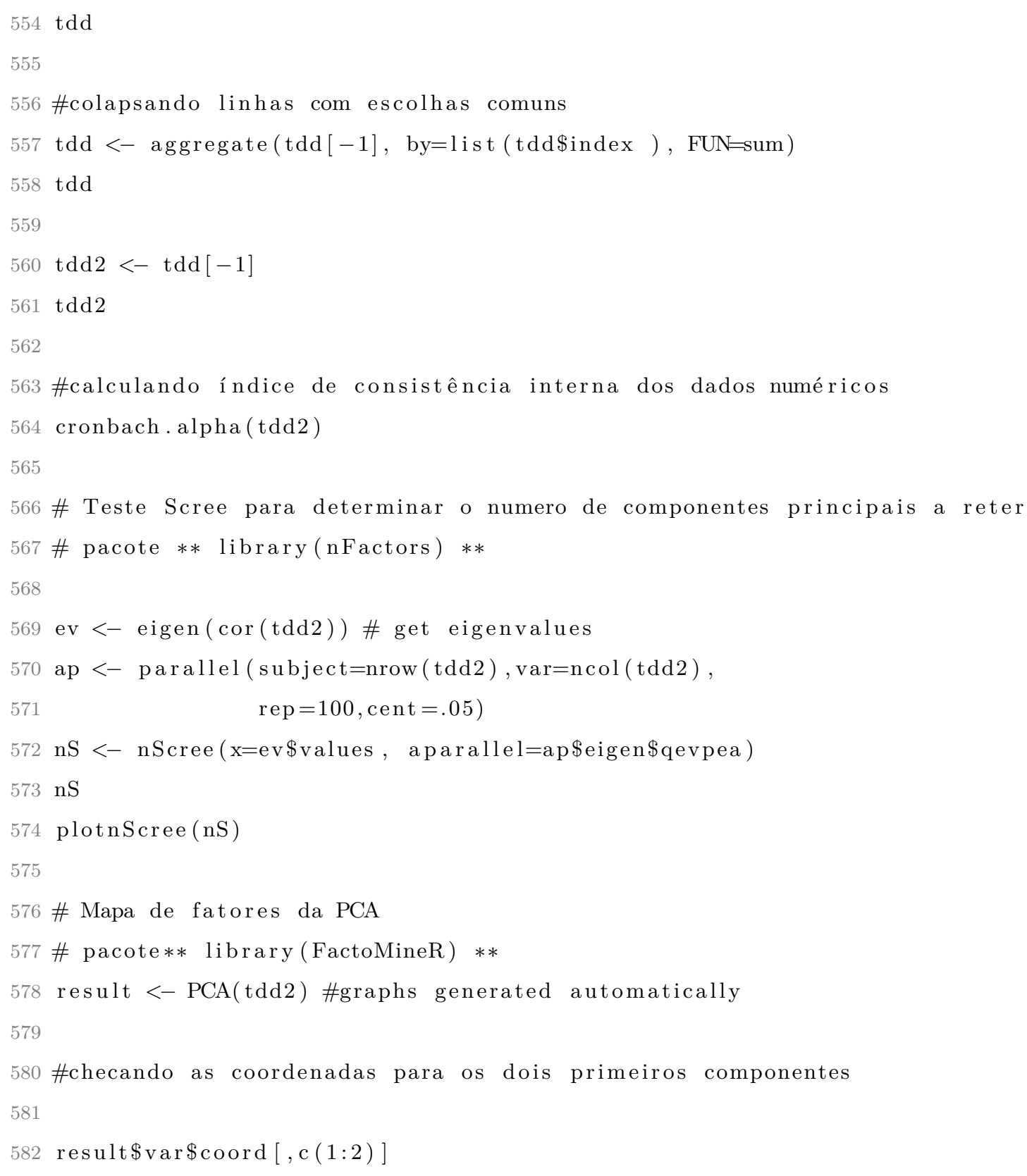

